MARCOS HENRIQUE BUENO DA SILVA

MODELO PARA ESTIMATIVA DOS CUSTOS DE CONSTRUÇÃO DAS SUPERFÍCIES PAVIMENTADAS PARA OPERAÇÕES DE AERONAVES EM AEROPORTOS 
MARCOS HENRIQUE BUENO DA SILVA

\title{
MODELO PARA ESTIMATIVA DOS CUSTOS DE CONSTRUÇÃO DAS SUPERFÍCIES PAVIMENTADAS PARA OPERAÇÕES DE AERONAVES EM AEROPORTOS
}

\author{
Versão Corrigida \\ (Versão original encontra-se na unidade que aloja o Programa de Pós-graduação)
}

Dissertação apresentada à Escola

Politécnica da Universidade de São Paulo para obtenção do título de Mestre em Ciências

Orientador: Prof. Livre-Docente Ubiraci Espinelli Lemes de Souza

São Paulo 
MARCOS HENRIQUE BUENO DA SILVA

\title{
MODELO PARA ESTIMATIVA DOS CUSTOS DE CONSTRUÇÃO DAS SUPERFÍCIES PAVIMENTADAS PARA OPERAÇÕES DE AERONAVES EM AEROPORTOS
}

\author{
Versão Corrigida \\ (Versão original encontra-se na unidade que aloja o Programa de Pós-graduação)
}

Dissertação apresentada à Escola Politécnica da Universidade de São Paulo para obtenção do título de Mestre em Ciências

Área de Concentração:

Inovação na Construção Civil

Orientador: Prof. Livre-Docente Ubiraci Espinelli Lemes de Souza

São Paulo 
Autorizo a reprodução e divulgação total ou parcial deste trabalho, por qualquer meio convencional ou eletrônico, para fins de estudo e pesquisa, desde que citada a fonte.

Este exemplar foi revisado e corrigido em relação à versão original, sob responsabilidade única do autor e com a anuência de seu orientador.

São Paulo, de de

Assinatura do autor:

Assinatura do orientador:

\section{Catalogação-na-publicação}

Silva, Marcos Henrique Bueno da

Modelo para estimativa dos custos de construção das superfícies pavimentadas para operações de aeronaves em aeroportos / M. H. B. Silva -versão corr. -- São Paulo, 2020.

$156 \mathrm{p}$.

Dissertação (Mestrado) - Escola Politécnica da Universidade de São Paulo. Departamento de Engenharia de Construção Civil.

1.Aeroportos 2.Custos de construção 3.Pavimentos aeroportuários 4.Modelagem paramétrica I.Universidade de São Paulo. Escola Politécnica. Departamento de Engenharia de Construção Civil II.t. 
Aos meus pais. 


\section{AGRADECIMENTOS}

Agradeço, de modo muito especial, ao Professor Dr. Ubiraci Espinelli Lemes de Souza, por acreditar em meu trabalho e por toda sua confiança sempre depositada nesse discípulo. Também enalteço sua amizade, mantida e ampliada, desde a época da minha graduação. Seus ensinamentos orientam e auxiliam minha jornada.

Aos Professores Dr. Hermes Fajersztajn e Dr. Eduardo loshimoto, pelos ensinamentos proporcionados em suas cadeiras e pelas construtivas e pertinentes contribuições para aperfeiçoamento dessa dissertação.

Aos demais professores, pesquisadores e funcionários da Universidade de São Paulo, em especial aos da Poli. Certamente todo o grupo, de alguma forma, contribuiu para o meu desenvolvimento acadêmico e pessoal.

A minha mãe Elza e ao meu pai José Aparecido (in memoriam), que sempre se esforçaram para propiciar-me uma instrução de alta qualidade, além de transmitirem com muito amor e carinho ensinamentos que pudessem tornar-me um cidadão comprometido com os melhores valores.

Aos amigos que ganhei ao longo da jornada, em especial da turma do mestrado e da graduação em engenharia civil nesta escola.

Também não poderia esquecer de minha querida irmã Juliana e meu cunhado Douglas, que como eu, graduaram-se em engenharia civil nestes mesmos bancos da Poli e a meus queridos afilhados, José e Joaquim. Agradeço por vocês colaborarem a cada dia para que eu seja melhor em tudo que faço.

Por fim, agradeço a minha companheira, confidente e maior incentivadora nessa empreitada, minha amada esposa Ana Cecília, pois juntos não há estrelas que não possamos alcançar, nem sonhos que não possamos realizar! 
"Se consegui ver mais longe é porque o fiz sobre os ombros de gigantes."

Isaac Newton 


\section{RESUMO}

O desenvolvimento da infraestrutura aeroportuária é parte fundamental na contribuição para o crescimento econômico e social de um país, principalmente em países com as dimensões e características do Brasil. Nesse contexto, esse trabalho apresenta um modelo para estimar os custos de construção de elementos primordiais de um aeroporto - as superfícies pavimentadas para operações de aeronaves: Pista de pouso e decolagem, Pistas de táxi e Pátio de estacionamento de aeronaves. A modelagem desenvolvida constitui uma ferramenta que auxilia no prognóstico preliminar de custos de construção, análises de viabilidade e também na comparação de alternativas construtivas desses elementos. Com base em informações preliminares, utilizando uma modelagem paramétrica proposta, podem ser estimados os custos diretos de construção dessas partes do aeroporto. É apresentada uma revisão da literatura sobre custos em obras de construção civil, modelagem paramétrica e aeroportos, visando entendimento do empreendimento. Apresenta-se uma visão do aeroporto como sendo uma obra composta por diversas partes e, através da modelagem desenvolvida, considerando demanda a ser atendida, modelos de aeronaves previstas nas operações e localidade do empreendimento, obtém-se informações quantitativas e qualitativas que permitem estimar os custos de construção das superfícies pavimentadas para operação de aeronaves. Ao final, conclusões sobre os resultados obtidos são tecidas, além de indicação de sugestões para desenvolvimentos futuros e próximos passos para essa área de pesquisa.

Palavras-Chave: Aeroportos; Custos de construção; Pavimentos aeroportuários; Modelagem paramétrica. 


\begin{abstract}
The development of airport infrastructure plays a fundamental part towards the country's economic and social growth, mainly with the dimensions and characteristics of Brazil. In this context, this work presents a model for estimating the costs of constructing the primordial elements of an airport - the paved surfaces for aircraft operations: Runway, Taxiways and Aprons. The developed model is a tool that assists in feasibility analysis, allowing to compare possibilities and alternatives for the construction of these elements. Based on preliminary information, using a proposed parametric model, direct construction costs of this parts can be estimated. A review of the literature on costs in construction, parametric modeling and airports is presented, aiming to understand the project. In a view of the airport as a product composed by several elements, through the modeling developed, considering demand to be met, aircraft models forecasted for the operations and location of the enterprise, information is obtained in terms of quantitative and qualitative aspects that allow to estimate the costs of construction of paved surfaces for aircraft operation. At the end, conclusions about the results obtained are woven, besides indication of future developments and next steps for this research area.
\end{abstract}

Keywords: Airports; Construction costs; Airport pavements; Parametric modeling. 


\section{LISTA DE FIGURAS}

Figura 1 - Aeroportos no Brasil em 2012 e os previstos com o Programa de Aviação Regional 2

Figura 2 - Comparação entre as malhas aéreas do Brasil e Estados Unidos da América 4

Figura 3 - Método de desenvolvimento do trabalho. .12

Figura 4 - Processo para modelagem paramétrica. .13

Figura 5 - Etapas de um empreendimento da construção civil...............................23

Figura 6 - Etapas do processo de análise de alternativas .....................................27

Figura 7 - Estimativa de custos através do Fator de capacidade ............................28

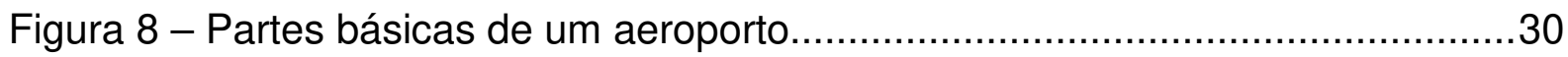

Figura 9 - Componentes de um aeroporto ........................................................

Figura 10 - Conceitos de distribuição horizontal aplicáveis para TPS ......................33

Figura 11 - Conceitos de distribuição verticais aplicáveis para TPS ........................34

Figura 12 - Arquiteturas de sistemas de malhas aéreas .........................................35

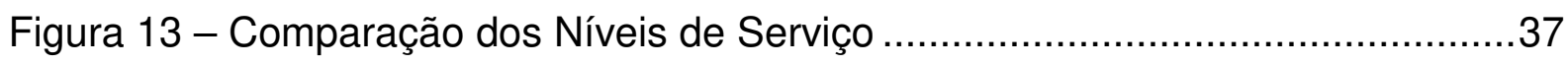

Figura 14 - Componentes de um aeroporto (visão sistêmica) .................................39

Figura 15 - Elementos pavimentados destinados à operação de aeronaves em aeroportos 40

Figura 16 - Visão analítica aplicada às superfícies pavimentadas para operação de aeronaves.

Figura 17 - Estrutura de um pavimento aeroportuário típico ..................................42

Figura 18 - Estrutura básica de pavimento flexível.............................................4

Figura 19 - Estrutura básica de pavimento rígido ...............................................45

Figura 20 - Comparação da forma de distribuição de carga em pavimentos equivalentes.... .46

Figura 21 - Afundamento do pavimento asfáltico em um Pátio de estacionamento de aeronaves.

Figura 22 - Número de informações versus precisão na estimativa de custos de projetos de construção civil 
Figura 23 - Situação do modelo paramétrico como método para estimativa de custos de projetos 56

Figura 24 - Exemplo de regressão linear para análise de variáveis 59 Figura 25 - Participação das companhias aéreas no mercado doméstico brasileiro de transporte aéreo. 70

Figura 26 - Taxa de ocupação dos assentos em operações domésticas brasileiras 74 Figura 27 - Modelamento paramétrico. .77

Figura 28 - Sistemas de Pistas de táxi considerando forma de atendimento da demanda .80

Figura 29 - Sistema Complexo de Pistas de Táxi .89

Figura 30 - Detalhes do Sistema Complexo de Pistas de Táxi. .90

Figura 31 - Exemplo de extrato da modelagem para pavimento aeroportuário 98 Figura 32 - Fluxograma para estimativa dos custos de construção das superfícies pavimentadas para operação de aeronaves em aeroportos 110 Figura 33 - Pista de Táxi para maior fluxo de aeronaves (aeroporto de Curitiba) ..119 Figura 34 - Pista de Táxi de saída rápida para maior fluxo de aeronaves (aeroporto de Curitiba). 


\section{LISTA DE TABELAS}

Tabela 1 - Nível de serviço (descrição qualitativa) ................................................36

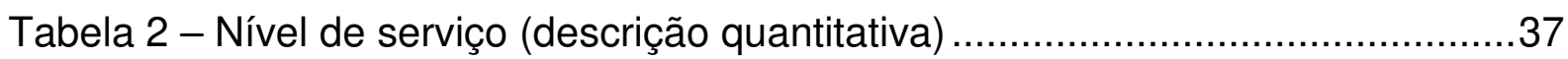

Tabela 3 - Peso de decolagem das aeronaves caracterizadas .............................74

Tabela 4 - Valores característicos para capacidade de suporte do subleito na

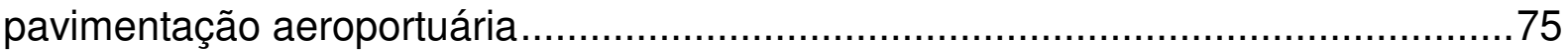

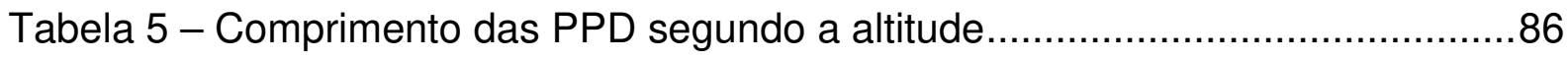

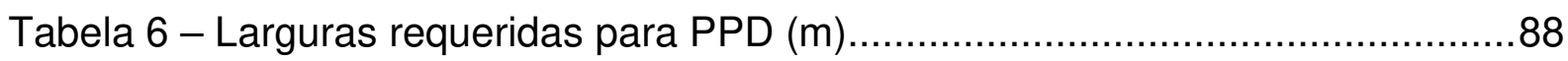

Tabela 7 - Larguras requeridas para acostamentos da PPD - de cada lado $(\mathrm{m})$.....88

Tabela 8 - Distâncias mínimas de separação entre PPD e PTX paralela $(\mathrm{m})$..........91

Tabela 9 - Modelos de aeronaves e participação nas operações aéreas domésticas

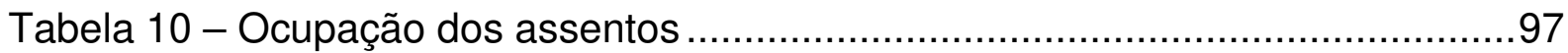

Tabela 11 - Decolagens anuais para cada modelo de aeronave ..........................97

Tabela 12 - Especificações do agregado considerado para sub-base .....................99

Tabela 13 - Especificações do agregado considerado para base .........................100

Tabela 14 - Espessura total para pavimentação flexível frente à demanda $(\mathrm{m})$.....100

Tabela 15 - Espessura total para pavimentação rígida frente à demanda $(\mathrm{m})$........101

Tabela 16 - Custos considerados para itens empregados na composição do modelo

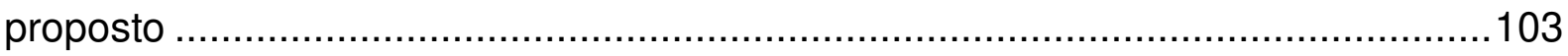

Tabela 17 - Custos unitários estimados para pavimento aeroportuário..................107

Tabela 18 - Custos parametrizados de pavimentação ......................................118

Tabela 19 - Comprimento das PPD empregando a modelagem paramétrica desenvolvida em comparação com o comprimento real das PPD dos aeroportos

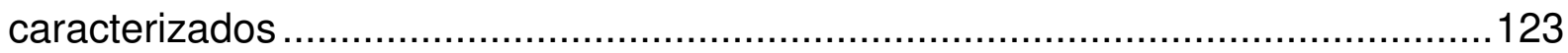

Tabela 20 - Custos médios para pavimentação de aeroportos ............................127 


\section{LISTA DE QUADROS}

Quadro 1 - Critérios aplicáveis a uma pesquisa ............................................11

Quadro 2 - Atributos da pesquisa desenvolvida ...........................................12

Quadro 3 - Aeroportos caracterizados.......................................................63

Quadro 4 - Principais parâmetros influenciadores nos custos de construção - PPD,

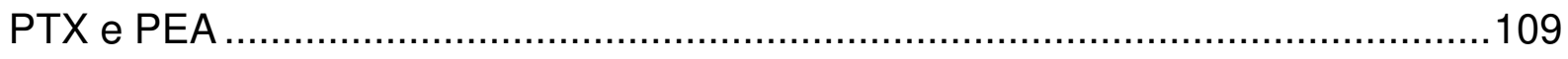

Quadro 5 - Quadro sinóptico com o modelamento paramétrico desenvolvido .......111 Quadro 6 - Matematização de exemplificação com aplicação do modelamento paramétrico 113

Quadro 7 - Exemplificação com aplicação do modelamento paramétrico 116 


\section{LISTA DE GRÁFICOS}

Gráfico 1 - Correlação entre altitude e comprimento da PPD para aeroportos no Brasil 87

Gráfico 2 - Correlação entre demanda e área para PEA …...................................93

Gráfico 3 - Correlação entre CBR do subleito e espessura da pavimentação flexível 101

Gráfico 4 - Correlação entre espessura do pavimento flexível e custo de construção 107 


\section{LISTA DE SIGLAS}

ABNT Associação Brasileira de Normas Técnicas

ACRP Airport Cooperative Research Program

ADRM Airport Development Reference Manual

AIS Serviços de Informação Aeronáutica

ANAC Agência Nacional de Aviação Civil

BIM Building Information Modeling

DECEA Departamento de Controle do Espaço Aéreo

EPUSP Escola Politécnica da Universidade de São Paulo

EUA Estados Unidos da América

FAA Federal Aviation Administration

FGV Fundação Getúlio Vargas

IATA International Air Transport Aviation

IBGE Instituto Brasileiro de Geografia e Estatística

ICAO International Civil Aviation Organization

INFRAERO Empresa Brasileira de Infraestrutura Aeroportuária

PDAR Plano de Desenvolvimento dos Aeroportos Regionais

RBAC Regulamento Brasileiro de Aviação Civil

RBHA Regulamento Brasileiro de Homologação Aeronáutica

SAC Secretaria de Aviação Civil

TPS Edifício Terminal de Passageiros

TWR Torre de Controle de Aeródromo

USP Universidade de São Paulo 


\section{SUMÁRIO}

1. INTRODUÇÃO

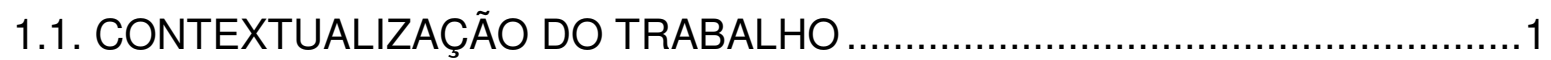

1.1.1. Importância do transporte aéreo para o Brasil......................................1

1.1.2. Importância das estimativas preliminares de custos na construção civil .6

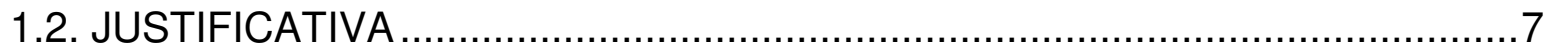

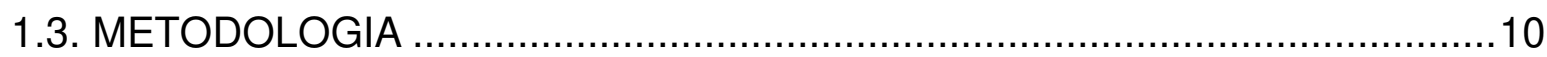

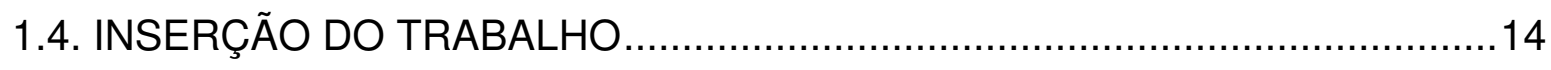

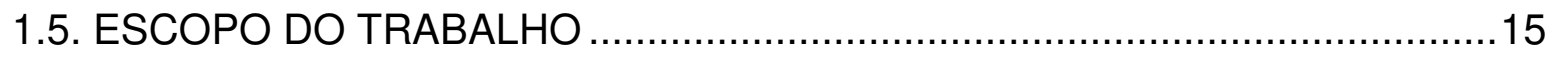

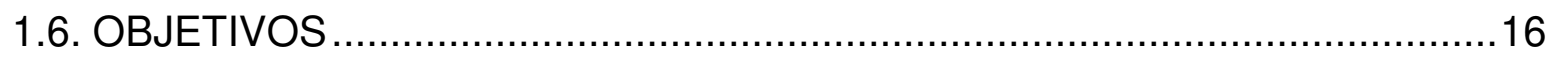

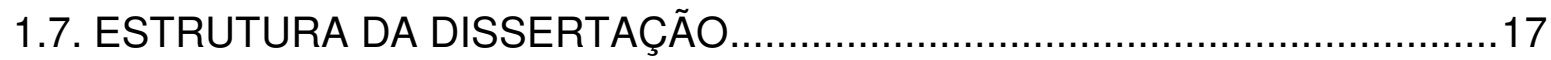

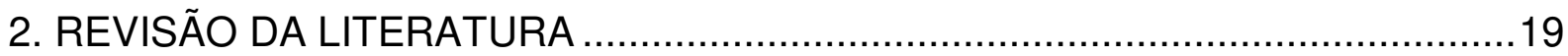

2.1. CUSTOS EM OBRAS DE CONSTRUÇÃO CIVIL …...................................19

2.1.1. Emprego da estimativa de custos em obras de construção civil...............20

2.1.2. Métodos para estimativa de custos em obras de construção civil ............24

2.1.3. Conceitos relacionados a custos na construção civil ...............................28

2.2. AEROPORTOS - ENTENDIMENTO DO PRODUTO ..................................29

2.3. SUPERFÍCIES PAVIMENTADAS PARA OPERAÇÃO DE AERONAVES .......39

2.3.1. Pavimentos aeroportuários ................................................................... 41

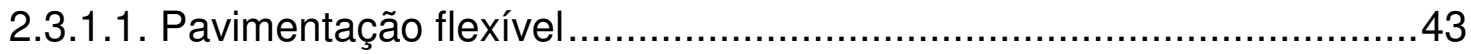

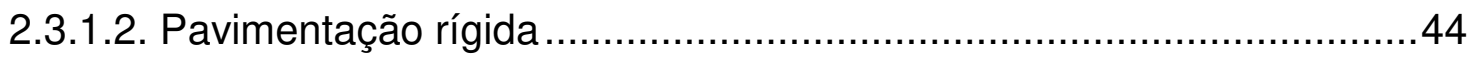

2.3.2. Dimensionamento de pavimentos aeroportuários..................................47

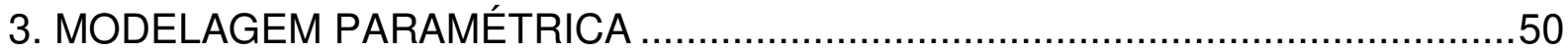

3.1. ESTUDOS SOBRE ESTIMATIVAS PARAMÉTRICAS DE CUSTOS NA

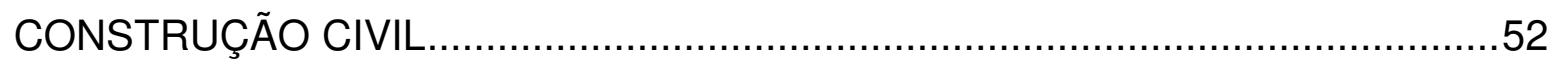

3.2. APLICAÇÕES DE RELAÇÕES PARAMÉTRICAS PARA ESTIMAR CUSTOS

3.3. CONCEITOS SOBRE MODELAGEM PARAMÉTRICA ….........................55

3.4. DIFICULDADES NO USO DA MODELAGEM PARAMÉTRICA.....................58 
3.5. CONCEITOS DE ESTATÍSTICA ENVOLVIDOS NO USO DE MODELOS PARAMÉTRICOS

4. CARACTERIZAÇÃO DOS COMPONENTES DO SISTEMA AEROPORTUÁRIO BRASILEIRO. 61

4.1. CARACTERIZAÇÃO DOS AEROPORTOS BRASILEIROS ..........................61

4.1.1. Capacidade de atendimento de passageiros e demanda atendida ..........64

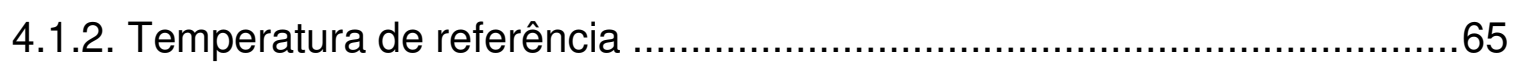

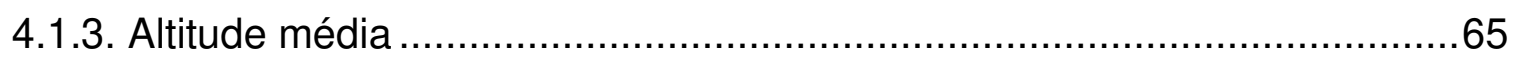

4.1.4. Declividade longitudinal da Pista de pouso e decolagem ........................66

4.1.5. Pátio de estacionamento de aeronaves ................................................66

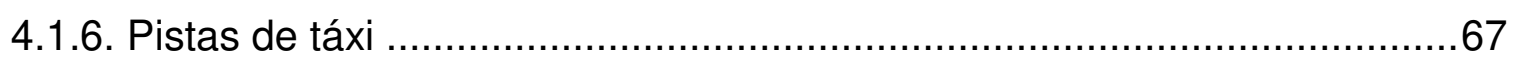

4.1.7. Pistas de pouso e decolagem .........................................................68

4.2. CARACTERIZAÇÃO DAS FROTAS DE AERONAVES DAS COMPANHIAS AÉREAS BRASILEIRAS

4.3. CARACTERIZAÇÃO DAS AERONAVES MAIS OPERADAS NOS

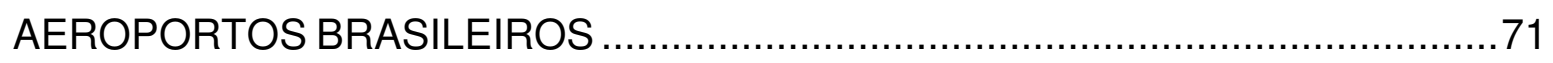

4.3.1. Características das aeronaves que influenciam no dimensionamento dos elementos pavimentados de um aeroporto .................................................. 72

4.4. CARACTERIZAÇÃO DA PAVIMENTAÇÃO AEROPORTUÁRIA.....................75

4.4.1. Capacidade de suporte do subleito.....................................................75

5. DESENVOLVIMENTO DO MODELO PARAMÉTRICO PARA ESTIMATIVA DOS CUSTOS DE CONSTRUÇÃO DAS SUPERFÍCIES PAVIMENTADAS PARA OPERAÇÃO DE AERONAVES EM AEROPORTOS .............................................77

5.1. PARAMETRIZAÇÕES APLICADAS NO MODELAMENTO ….........................78

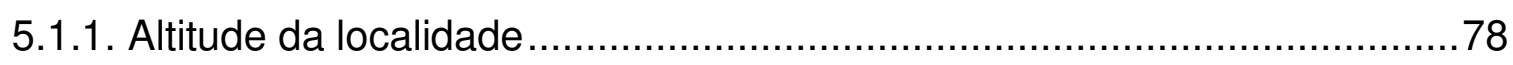

5.1.2. Capacidade de suporte do subleito (solo original) .................................79

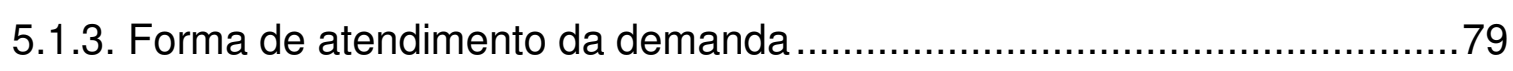

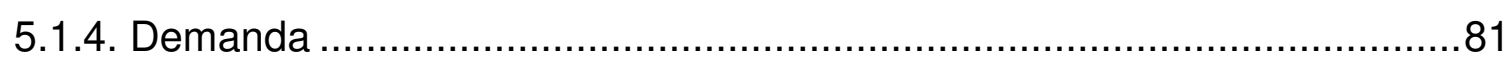

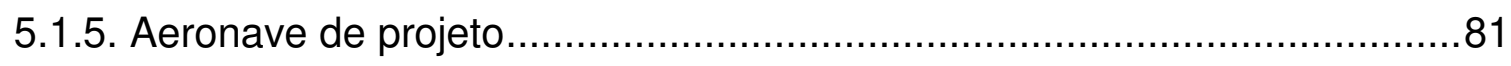

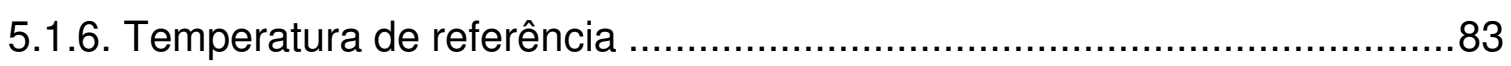

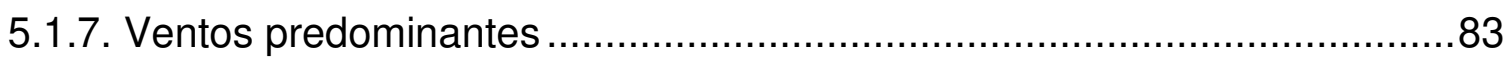

5.1.8. Declividade longitudinal da Pista de pouso e decolagem ........................83 
5.1.9. Taxa de crescimento do mercado de aviação civil .84

5.2. DETERMINAÇÃO DOS PARÂMETROS FÍSICOS PARA APLICAÇÃO NO

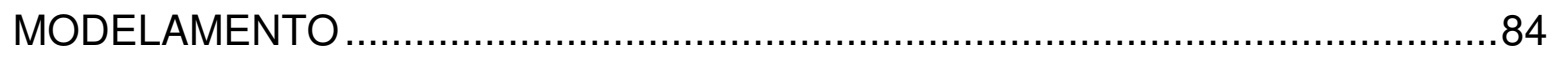

5.2.1. Comprimento da Pista de pouso e decolagem .....................................84

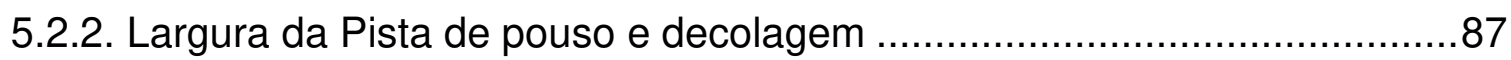

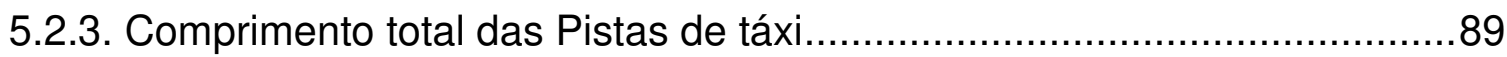

5.2.3.1. Comprimento total de Sistema Complexo de Pistas de Táxi em

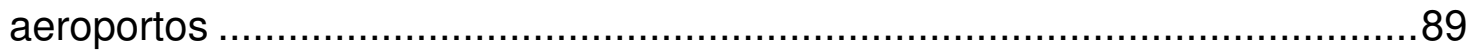

5.2.3.2. Comprimento total do Sistema Simples de Pista de Táxi em aeroportos

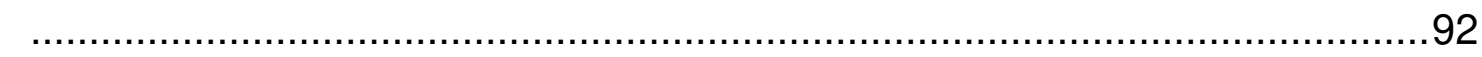

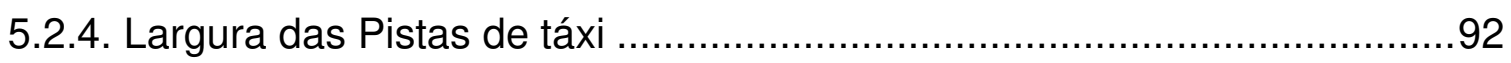

5.2.5. Área do Pátio de estacionamento de aeronaves ....................................93

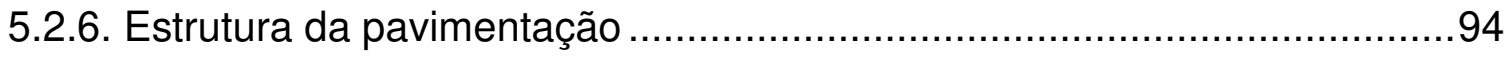

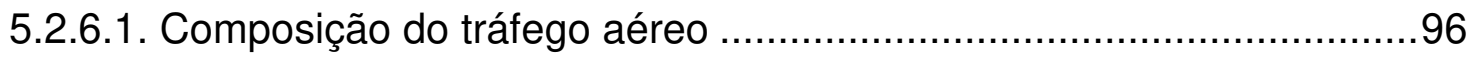

5.2.6.2. Demanda e quantidade de decolagens .........................................96

5.2.6.3. Espessuras das camadas da pavimentação ....................................100

5.3. CUSTOS UNITÁRIOS PARA APLICAÇÃO NO MODELAMENTO ...............102

5.3.1. Levantamento das quantidades de materiais e serviços para construção de superfícies pavimentadas para operações de aeronaves em aeroportos.........104

5.3.2. Estimativas dos custos para aplicação nas modelagens ........................106

5.4. MODELO PARAMÉTRICO PARA ESTIMATIVA DOS CUSTOS DE CONSTRUÇÃO DAS SUPERFÍCIES PAVIMENTADAS PARA OPERAÇÕES DE

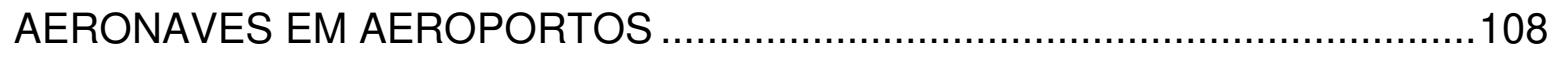

6. APLICAÇÃO DO MODELO PARAMÉTRICO DESENVOLVIDO..........................112

6.1. ESTIMATIVA DOS CUSTOS DE CONSTRUÇÃO ...................................112

6.2. ANÁLISE COMPARATIVA DOS CUSTOS DE CONSTRUÇÃO - IMPACTO DA LOCALIDADE E TIPO DE PAVIMENTAÇÃO …...............................................114

6.3. ANÁLISE DOS CUSTOS DE CONSTRUÇÃO FRENTE ÀS OPERAÇÕES

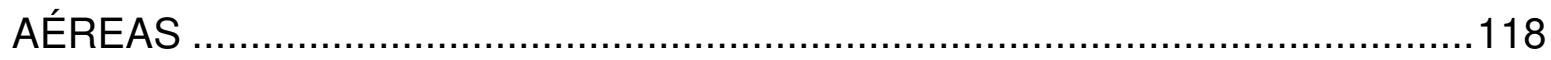

6.4. AVALIAÇÃO DO COMPRIMENTO DE PISTAS DE POUSO E DECOLAGEM 


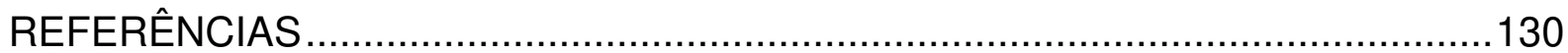

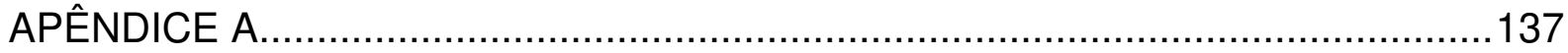

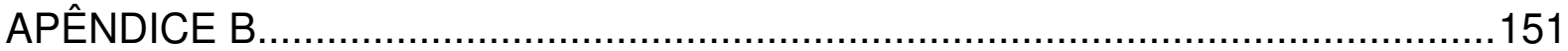

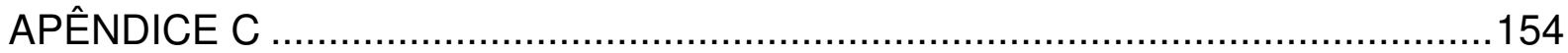

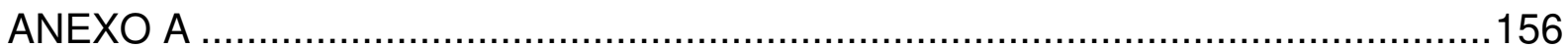




\section{INTRODUÇÃO}

Visando melhor organização e compreensão do trabalho, neste capítulo introdutório é apresentada uma contextualização do assunto frente à questão da necessidade de melhoria da infraestrutura aeroportuária do país, passando pelo diagnóstico da importância da pesquisa realizada. Na sequência, a justificativa, a metodologia, a inserção do trabalho, os objetivos e a estrutura da dissertação são apresentados.

\subsection{CONTEXTUALIZAÇÃO DO TRABALHO}

\subsubsection{Importância do transporte aéreo para o Brasil}

O transporte aéreo é muito importante para o deslocamento e integração em países com as características do Brasil (país com mais de 8,5 milhões de quilômetros quadrados de área).

Diferentemente de outros países de dimensões continentais, servidos por ferrovias, o Brasil tem nas rodovias seu principal modal de transporte, com imensas distâncias a percorrer e dificuldades impostas pelo clima tropical, tendo-se, como resultado: transporte caro e ineficiente.

Nessa perspectiva, o transporte aéreo surge como ótima estratégia para conectar as regiões do território (BRASIL, 2015a).

O movimento de pessoas e cargas é uma necessidade fundamental no desenvolvimento da sociedade em geral; nesse sentido, o transporte ideal seria aquele que tornasse esse serviço imperceptível, isto é, instantâneo, com capacidade ilimitada, sempre disponível e a custo zero. No entanto, isso ainda não é possível; dessa forma, investimentos em sistemas de transporte eficientes são necessários (FERNANDES; PACHECO, 2016). 
Nesse contexto, o aeroporto se tornou um elemento vital para o crescimento dos negócios e da indústria em uma comunidade, ao proporcionar acesso aéreo a empresas que precisam atender às demandas de mercado relacionadas a suprimentos, concorrência e expansão. Comunidades que não contam com aeroportos ou com serviço aéreo suficiente apresentam limitações em sua capacidade de crescimento econômico (YOUNG; WELLS, 2014).

A população brasileira, nos últimos anos (principalmente após 2000), pelo menos antes da grave crise econômica e política na qual o país está mergulhado desde 2014, experimentou elevação da renda e melhoria nas condições econômicas e sociais. A infraestrutura aeroportuária e malha de conexões aéreas deveria ter crescido seguindo os patamares de elevação de renda, com a ampliação do acesso a esse modal de transporte, de forma a propiciar atendimento aos anseios da sociedade.

Em 2012, ainda no bojo do período de engrandecimento da economia, o governo federal estabeleceu o Programa Federal de Auxílio a Aeroportos, que contemplava o fortalecimento e ampliação da aviação regional (NOVAES; SOUZA, 2016). Esse programa tem o objetivo de ampliar, adequar e modernizar a infraestrutura aeroportuária do país.

A Figura 1 apresenta a quantidade de aeroportos em operação antes do início do referido programa (2012) e quantidade (que seria alcançada) com o programa aplicado em sua integralidade. Verifica-se a grande quantidade de aeroportos a serem construídos, além da reforma ou ampliação dos já existentes.

Figura 1 - Aeroportos no Brasil em 2012 e os previstos com o Programa de Aviação Regional

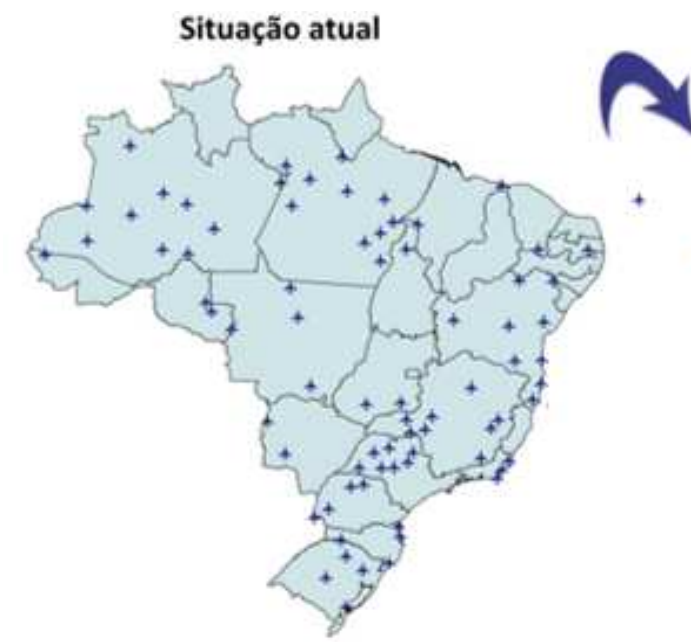
Com o Programa de Aviação Regional

Fonte: BRASIL (2015a)

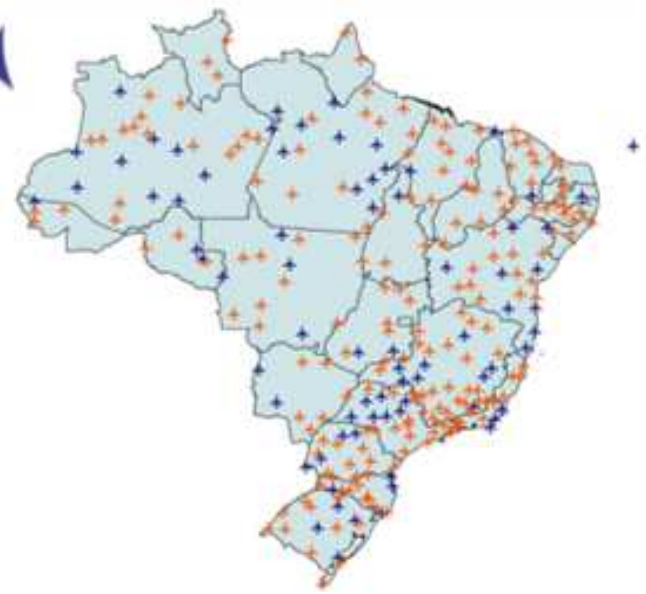


Devido à crise econômica crescente nesses últimos anos (principalmente a partir de 2014), o referido programa foi sendo gradualmente esvaziado. Inicialmente estava previsto o investimento de $\mathrm{R} \$ 7,3$ bilhões, sendo esse montante empregado em reformas, ampliações, melhorias e construção de aeroportos regionais por todo o território, contemplando ao menos 270 aeroportos espalhados pelo Brasil (BRASIL, 2015a).

Todavia, tal programa sofreu uma profunda alteração e grande redução de magnitude, tanto na quantidade de aeroportos contemplados, quanto nos recursos a serem investidos. Foi anunciado, em agosto de 2016, que dos 270 aeroportos apenas 53 seriam contemplados com investimentos, redução de mais de $80 \%$, e o valor global a ser aplicado também foi reduzido, sendo agora disponibilizados apenas $R \$ 2,4$ bilhões, corte de mais de 67\% (NOVAES; SOUZA, 2016).

Até o momento de elaboração desse material, cortes ainda mais significativos estavam em andamento e o futuro do programa estava cada vez mais incerto. Acrescenta-se, ainda, a mudança no comando do executivo federal e de toda a reorganização do estado brasileiro em janeiro de 2019.

Vasconcelos (2007) enfatiza que experiências nacionais e internacionais constatam que a infraestrutura de transportes adequada tendem a incrementar 0 desenvolvimento econômico e social para as populações e regiões contempladas.

Para países de grandes dimensões territoriais, como o Brasil, a constante ampliação e modernização da malha aérea é de suma importância. Deve-se levar em consideração a necessidade de desenvolver diversas regiões do território, em especial as regiões interiores.

A Figura 2 apresenta a diferença da malha aérea doméstica brasileira em relação à norte-americana (mais desenvolvida indústria da aviação civil mundial). Fica evidente o quanto ainda o desenvolvimento da infraestrutura aeronáutica brasileira e a necessidade de construção de novos aeroportos se fazem necessários. 
Figura 2 - Comparação entre as malhas aéreas do Brasil e Estados Unidos da América

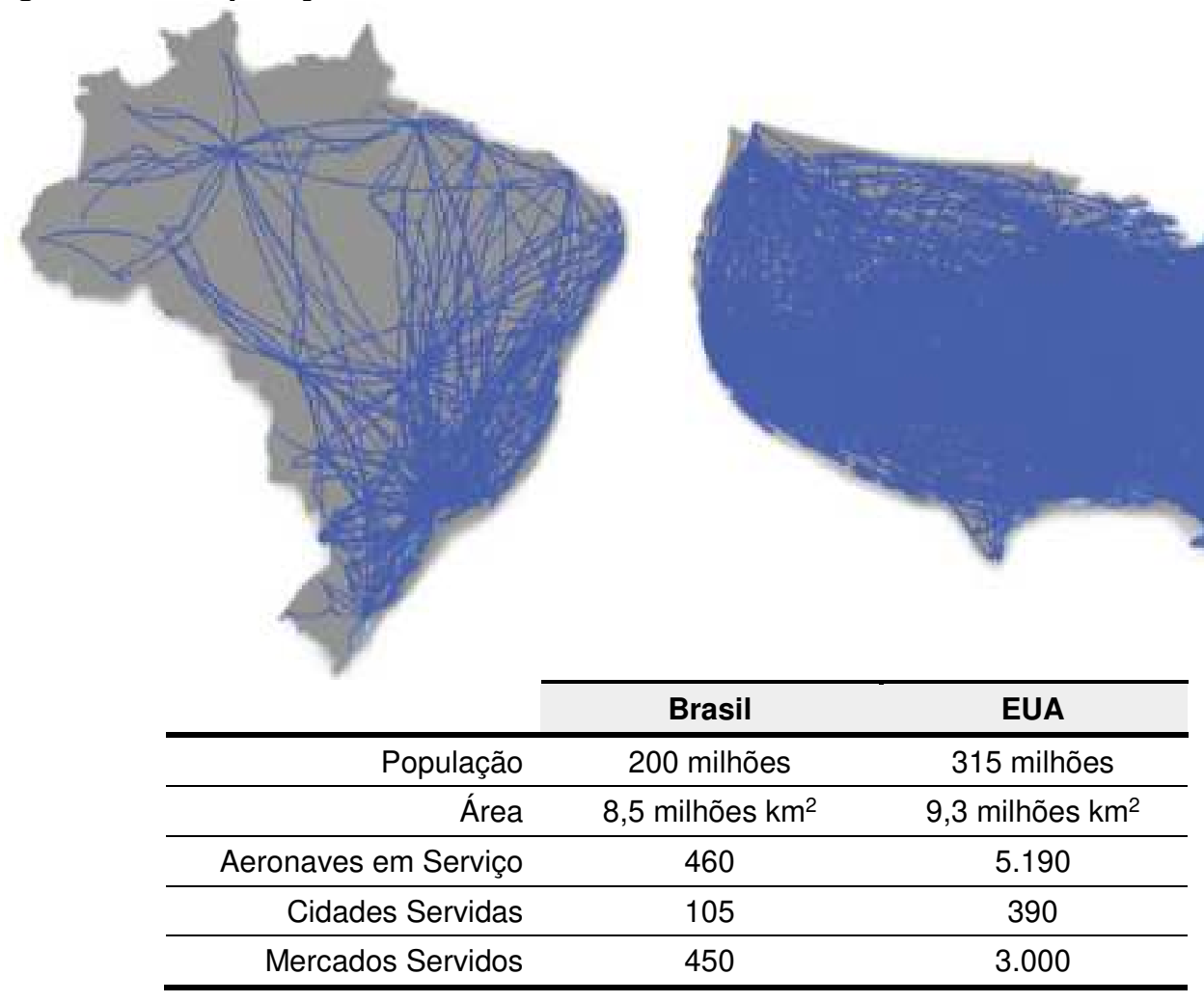

Fonte: BRASIL (2015a) - Adaptado

Atender regiões remotas do território e partes mais interiores, dotando cidades médias ou polos regionais com aeroportos comerciais, apresenta-se como imperativo. Para solucionar esse gargalo ao desenvolvimento nacional e democratizar o transporte no país, o governo tinha o objetivo de dotar o Brasil de uma rede de aeroportos regionais operando a preços competitivos, de forma a garantir que $96 \%$ da população brasileira estivesse a 100 quilômetros ou menos de um aeroporto com condições de operar voos regulares (BRASIL, 2015a).

Nesse contexto, o brasileiro ainda viaja pouco de avião, com uma média de 0,5 viagem ao ano, frente a uma média de 1,7 em países desenvolvidos e 2,5 nos Estados Unidos da América; no entanto, mesmo com a quantidade de aeroportos limitada que compõe o parque aeronáutico brasileiro, entre 2003 e 2013, a movimentação de passageiros triplicou e existe a previsão de que seja novamente triplicada em 20 anos (BRASIL, 2015b). 
Segundo ANAC (2018a) ocorreu um grande crescimento do mercado de transporte aéreo no Brasil ao longo da última década - aumento acumulado de 170\% no número de passageiros transportados entre 2004 e 2014.

Todo esse incremento na demanda pelo transporte aéreo é acompanhado por uma série de desafios. Paralelamente ao aumento, ocorre um processo de sobrecarga da infraestrutura nacional existente para aviação civil.

Alguns aeroportos do País são pressionados a compatibilizar suas instalações (ABREU, 2017). Em outros casos, novos aeroportos devem ser construídos, visando atendimento da população de forma mais otimizada.

Segundo BRASIL (2015a), o transporte aéreo é estratégico; no entanto, há poucos aeroportos operando voos regulares nas regiões mais interiores e os que existem têm infraestrutura precária, sem investimentos há anos.

Aeroportos próximos aos grandes centros (capitais de estados e regiões litorâneas) têm recebido grande atenção e volume de investimentos na última década. Principalmente com 0 advento das concessões dessas infraestruturas para operadores aeroportuários da iniciativa privada.

Os empreendimentos aeroportuários são obras de infraestrutura de larga complexidade e com elevados custos de implantação, seja na construção, reforma ou ampliação.

Cabe ressaltar ainda que, segundo Young e Wells (2014), cidades com boas dependências aeroportuárias lucram com negócios turísticos e relacionados a convenções, uma vez que representam receitas substanciais para hotéis, restaurantes, lojas de varejo, eventos esportivos, boates, passeios turísticos, locadoras de automóveis e transporte local. Quanto a convenções, logicamente o tamanho e localização da cidade dita a quantidade de eventos; porém, por experiências observadas, até mesmo comunidades menores colhem renda adicional razoável com tais convenções.

Vale contextualizar que, em virtude de extensa e grave crise econômica e política no Brasil, diversos programas e áreas que dependem de investimentos dos governos 
(todas as esferas) e da iniciativa privada foram afetados. Nos projetos que envolvem a aviação civil, não foi diferente.

Quanto aos processos futuros de concessões de aeroportos, grandes mudanças de escopo e relações contratuais estão em andamento para as próximas rodadas de negociações. Espera-se que os investimentos em obras sejam ampliados nesses aeroportos.

\subsubsection{Importância das estimativas preliminares de custos na construção civil}

Em linhas gerais, segundo Mascaró (1998), o custo de uma edificação pode ser definido por sua concepção. Cada traçado aplicado ao projeto gerará diferentes consumos de insumos.

Com isso, os custos de empreendimentos de construção civil são mais afetados pelas decisões na fase de projeto que por aquelas tomadas pelos executores (construtores). Melhado e Agopyan (1995) verificaram que modificações no produto feitas depois das fases iniciais de um empreendimento podem ter impacto mais problemático nos custos.

A estimativa de custos constitui uma importante ferramenta para os diferentes agentes envolvidos num projeto. Para o empreendedor, a auxilia na verificação da viabilidade; para os projetistas, pode auxiliar na escolha entre tipologias de produto; para os construtores, serve para auxiliar na entrada em licitações e na elaboração de orçamentos de contratos (KARSHENAS, 1984).

Cardoso e Abiko (2000) acrescentam, ainda, que esse raciocínio permite também análise de inovações tecnológicas a serem aplicadas no projeto.

As estimativas de custo de construção permitem, também, que o empreendedor verifique se o negócio é factível e rentável, ou seja, se proporciona uma taxa de retorno atrativa (ROCHA LIMA, 1985).

Segundo Kato (2013), um prognóstico preciso de custos, com base em informações preliminares do empreendimento, que consiga comparar diferentes concepções, 
avaliando, inclusive, a produtividade e consumo de materiais, pode ser uma ferramenta muito poderosa para diferentes tomadas de decisões.

De todas as áreas da construção civil, o orçamento de uma obra é a atividade em que menos se troca conhecimento entre as empresas. Culturalmente, as construtoras tentam ocultar a maneira como se elabora o orçamento, se define o BDI e como preveem os seus lucros (RIBEIRO, R. L., 2014).

Nesse contexto, os custos de construção, reforma ou ampliação de empreendimentos como aeroportos, considerando todos os impactos econômicos ao setor de operações aéreas, sempre terão grande importância no processo decisório sobre alternativas para desenvolvimento da infraestrutura aeroportuária (VELÁSQUEZ; CASTAÑEDA; AGURRE, 2015).

\subsection{JUSTIFICATIVA}

A justificativa para o trabalho lastreia-se na necessidade de ampliação do acesso da população brasileira ao transporte aéreo, através da dotação de adequada e compatível infraestrutura aeroportuária, que permita redução dos custos operacionais e maior abrangência da malha aérea.

Vale também ressaltar a importância desse modal de transporte para o desenvolvimento econômico e social. Aeroportos adequados permitem a aceleração do desenvolvimento regional, ampliam as relações exteriores e dinamizam a economia.

Verificam-se no Brasil dificuldades referentes à infraestrutura aeroportuária desde os primórdios das operações comerciais com aeronaves. Na década de 1920 a empresa francesa Aéropostale, iniciou operações com aeronaves visando conectar o correio postal entre a Europa e a América do Sul, com entrada no continente através de cidades brasileiras e escalas em diversas outras; no entanto, a falta de pistas adequadas para operação de suas aeronaves, fez com que poucas cidades pudessem ser atendidas pelo serviço (MERMOZ, 1986). 
Alinha-se, ainda, a necessidade de otimização dos custos para obras de construção, reforma ou ampliação, imposta pelas restrições orçamentárias atuais para projetos de infraestrutura e anseios da sociedade e governo.

Devido ao supracitado, uma análise complementar mais precisa, ainda em fases preliminares de estudos de viabilidade de projetos, merece destaque, principalmente dentro do atual momento que atravessa o país, de profunda crise econômica e política e a carência cada vez mais latente por equipamentos de infraestrutura.

Os aeroportos dos grandes centros urbanos estão cada dia mais congestionados e o volume de operações é crescente.

Então, considerando todo o exposto, a pesquisa apresenta metodologia para estimativa de custos de construção de elementos vitais e que correspondem a grande parte dos investimentos quando são construídos aeroportos - as superfícies pavimentadas para operações das aeronaves (Pista de pouso e decolagem, Pistas de táxi e Pátio de estacionamento de aeronaves).

Nesse bojo, cabe ainda a colocação de que o elemento central e vital de um empreendimento aeroportuário - a Pista de pouso e decolagem, não permite implantação faseada, ou seja, o desenvolvimento dos outros elementos importantes de um aeroporto, como um Edifício Terminal de Passageiros (TPS), um Terminal de Cargas, ou até mesmo um Pátio de estacionamento de aeronaves podem ter a implantação faseada, no horizonte de projeto, conforme o crescimento da demanda ao longo do tempo.

A Pista de pouso e decolagem deve, desde a inauguração de um aeroporto, possuir as dimensões que atendam a aeronave de projeto e todo o conjunto de aeronaves previsto. Esse fato justifica, também, a importância de estimar o custo desse importante elemento que compõe as instalações construídas de um aeroporto.

Como é notória a relevância dos custos envolvidos em projetos dessa natureza, a pesquisa passa a ser de grande importância, visto que auxiliará no desenvolvimento, documentação de conhecimento e uso de um modelo para análise de viabilidade para obras de aeroportos. 
Principalmente dentro do novo contexto econômico do país, onde os custos de qualquer tipo de projeto devem sempre ser otimizados, estudos cada vez mais detalhados e abrangentes são necessários.

Há que se considerar ainda o desenvolvimento da Modelagem da Informação da Construção ${ }^{1}$ (BIM - Building Information Modeling), que sendo um processo integrado para criar, usar e atualizar um modelo digital de construção, podendo ser usado por todos os participantes do empreendimento, durante todo o ciclo de vida do projeto, segundo Eastman et al. (2013), pode encontrar na modelagem paramétrica desenvolvida uma ferramenta bastante interessante e compatível, desde as fases de estudos preliminares e de viabilidade.

Cabe ainda dizer que os processos construtivos em construção civil são muito menos estáveis que na indústria seriada. Existem mudanças, quanto a determinado serviço, de uma obra em relação a outra e, até mesmo, de um dia em relação a outro no desenvolvimento de determinado projeto (SOUZA, 2006).

Essas características são mais um incentivador para desenvolvimento de um modelo paramétrico, que se adequando ao tema em estudo, minimize essas incertezas correlatas à construção no que se traduz a custos prognosticados.

Destaca-se, ainda, que a literatura referente à temática das obras de construção civil em aeroportos é diminuta. Restringe-se, na maioria das vezes, a análises de demanda, concepção ou dimensionamento de aeroportos, linhas de pesquisas geralmente ligadas à engenharia de transportes, pesquisa operacional, economia ou logística. Cabe, portanto, um acréscimo de registro de conhecimento no que se refere a aspectos mais ligados às decisões na área de Construção Civil.

1 Tradução oficial presente na NBR/ISO 12006-2 e NBR 15965. 


\subsection{METODOLOGIA}

Resultado de uma pesquisa, aplicando-se métodos científicos, esta dissertação sintetiza dados e constatações sobre aeroportos como um elemento de infraestrutura e sobre como estimar os custos de construção das superfícies pavimentadas para operação de aeronaves desses empreendimentos.

Antes da apresentação da metodologia aplicada ao desenvolvimento deste trabalho, algumas definições e conceitos são importantes e são apresentados na sequência.

Segundo Marconi e Lakatos (2003), dissertação é um tipo de trabalho cientifico, apresentado ao final do curso de pós-graduação, visando obter o título de mestre, após defesa. Apresenta caráter didático, pois se constitui em um treinamento ou iniciação à investigação.

Pesquisa pode ser definida como um procedimento formal, com método de pensamento reflexivo, que requer um tratamento cientifico e se constitui no caminho para conhecer a realidade ou para descobrir verdades parciais (MARCONI; LAKATOS, 2003).

Gil (2008) define pesquisa como um procedimento racional e sistemático, com o objetivo de elaborar respostas aos problemas que são propostos. Nesse procedimento também deve ser considerado o desenvolvimento em diferentes etapas, que envolvem desde a formulação do problema até a apresentação dos resultados, utilizando, para isto, métodos, técnicas e outros procedimentos científicos.

Diferentes autores apresentam critérios e classificações que podem ser aplicados na caracterização de uma pesquisa acadêmica. Com isso alguns critérios previstos na literatura permitem situar melhor cada trabalho acadêmico desenvolvido frente a suas particularidades e características.

O Quadro 1 apresenta, de forma resumida, esses principais critérios com suas respectivas descrições. 
Quadro 1 - Critérios aplicáveis a uma pesquisa

\begin{tabular}{|c|c|}
\hline Critério & Descrição \\
\hline Método científico amplo & $\begin{array}{l}\text { Abordagem abstrata quanto à forma de se atingirem os objetivos da } \\
\text { pesquisa (método indutivo, dedutivo, hipotético-dedutivo, dialético). }\end{array}$ \\
\hline Natureza & $\begin{array}{l}\text { Quanto à aplicabilidade imediata dos resultados (pesquisa básica ou } \\
\text { aplicada). }\end{array}$ \\
\hline $\begin{array}{l}\text { Forma de abordagem do } \\
\text { problema }\end{array}$ & $\begin{array}{l}\text { Se as opiniões e informações obtidas são traduzidas ou não em } \\
\text { números para classificá-las e analisá-las (quantitativa e qualitativa, } \\
\text { respectivamente). }\end{array}$ \\
\hline $\begin{array}{l}\text { Sob o ponto de vista dos } \\
\text { objetivos a serem } \\
\text { alcançados }\end{array}$ & $\begin{array}{l}\text { - Exploratório: proporcionar ao pesquisador maior familiaridade com } \\
\text { o problema de pesquisa; } \\
\text { - Descritiva: descrição das características de determinada população } \\
\text { ou fenômeno e, em alguns casos, estabelecimento de relações } \\
\text { entre variáveis; } \\
\text { - Explicativa: tem como foco central a identificação de relações } \\
\text { causa-efeito entre fenômenos valendo-se, para isto, quase que } \\
\text { exclusivamente de métodos experimentais de investigação. }\end{array}$ \\
\hline $\begin{array}{l}\text { Segundo as fontes de } \\
\text { informação (técnicas de } \\
\text { coleta) }\end{array}$ & $\begin{array}{l}\text { - Documentação direta: pesquisa bibliográfica e documental; } \\
\text { - Documentação indireta: pesquisa de campo ou de laboratório; } \\
\text { - Observação direta intensiva: observação ou entrevista; } \\
\text { - Observação direta extensiva: questionário ou formulário. }\end{array}$ \\
\hline $\begin{array}{l}\text { Método de pesquisa (sob } \\
\text { o ponto de vista dos } \\
\text { procedimentos técnicos) }\end{array}$ & $\begin{array}{l}\text { De acordo com este critério, pode-se ter pesquisa bibliográfica, } \\
\text { pesquisa documental, pesquisa participante, levantamento (survey), } \\
\text { estudo de caso, pesquisa ação, construtive research, pesquisa } \\
\text { experimental, entre outros. }\end{array}$ \\
\hline
\end{tabular}

Fonte: MINGIONE (2016) - adaptado

método seguido neste trabalho emprega as observações do "pai da ciência moderna", Galileu Galilei, que observou um método experimental quantitativo, que se tornou, mais tarde, a metodologia padrão na esfera da investigação científica, no qual o processo envolve a realização de experiências controladas e reproduzíveis para testar, a qualquer momento, a validade de uma hipótese específica (CHALTON; MacARDLE, 2017). 
Dessa forma, pode-se situar a presente pesquisa, listando os atributos relativos ao trabalho desenvolvido, seguindo o descrito por Mingione (2016), de forma sintética, no Quadro 2.

\section{Quadro 2 - Atributos da pesquisa desenvolvida}

\begin{tabular}{ll}
\hline \multicolumn{1}{c}{ Critério } & \multicolumn{1}{c}{ Atributo } \\
\hline Método científico amplo & Método indutivo. \\
\hline Natureza & Pesquisa aplicada - possibilidade de aplicação imediata dos resultados. \\
\hline $\begin{array}{l}\text { Forma de abordagem do } \\
\text { problema }\end{array}$ & $\begin{array}{l}\text { Pesquisa quantitativa e qualitativa - os resultados apresentados têm } \\
\text { certo tratamento estatístico e abrangem resultados qualitativos. }\end{array}$ \\
\hline $\begin{array}{l}\text { Objetivos a serem } \\
\text { alcançados }\end{array}$ & $\begin{array}{l}\text { Pesquisa descritiva - busca descrever características ou fenômenos, } \\
\text { na medida em que busca estabelecer relações entre variáveis que } \\
\text { influenciam os custos das obras aeroportuárias. }\end{array}$ \\
\hline Fontes de informação & $\begin{array}{l}\text { Pesquisa bibliográfica, documental e entrevistas com especialistas do } \\
\text { setor. }\end{array}$ \\
\hline Método de pesquisa & Pesquisa bibliográfica e estudo de caso. \\
\hline
\end{tabular}

Fonte: Elaboração Própria

É pertinente, ainda, uma explanação sobre os métodos a serem aplicados em trabalhos científicos. Método pode ser definido como um conjunto das atividades sistemáticas e racionais que, com maior segurança e economia, permite alcançar o objetivo buscado (PALIARI, 1999).

Com isso, o método seguido no desenvolvimento do trabalho, em linhas gerais, é sintetizado na Figura 3.

Figura 3 - Método de desenvolvimento do trabalho

\section{FASE 1}

Revisão Bibliográfica

\section{FASE 2}

Definições para parametrização e desenvolvimento do modelo

\section{FASE 3}

Aplicação do

modelo e

análises
FASE 4

Conclusões

Fonte: Elaboração Própria 
Na Fase 1, a revisão bibliográfica sobre componentes de um aeroporto, suas funções e partes foi executada. Durante essa fase, buscou-se contato com especialistas em operações aeroportuárias e responsáveis por infraestruturas aeroportuárias. Quanto às revisões bibliográficas que versam sobre custos de obras, focou-se em publicações sobre métodos de estimativas empregados em obras de construção civil, com particularidades correlatas.

Com base nos levantamento e consolidação da revisão bibliográfica, iniciou-se a Fase 2, na qual foram definidos os parâmetros que seriam empregados na modelagem a ser proposta. Nessa fase, realizando uma analogia do proposto por Inouye (2009), buscou-se entender os métodos e parâmetros usados para a levantamento preliminar dos custos.

Na Fase 3, foi concebido um modelo e simuladas aplicações, permitindo as análises necessárias e visando estabelecer os mecanismos para estimar os custos dos elementos trabalhados, em fases preliminares de projetos de construção de aeroportos.

O fluxo apresentado na sequência (Figura 4) pautou a forma de desenvolvimento da modelagem paramétrica para estimativa de custo de construção neste trabalho. Valendo ainda ressaltar que essa atividade é um processo, segundo Eck et al. (2009).

\section{Figura 4 - Processo para modelagem paramétrica}

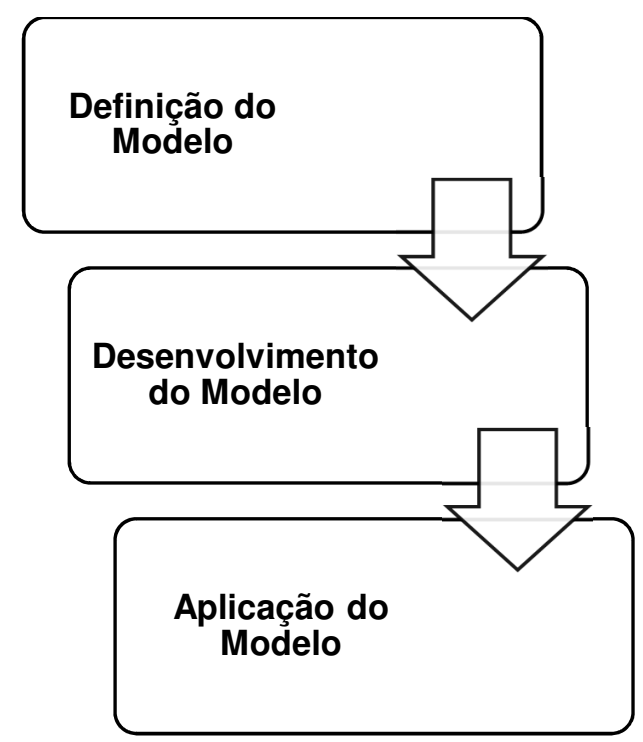

Fonte: Elaboração própria, com base em BARROS; OLIVEIRA; FERREIRA (2016) 
Após o desenvolvimento e emprego do modelo, na Fase 4, são tecidas as conclusões e considerações sobre 0 modelo apresentado, além da indicação para desenvolvimentos futuros deste trabalho.

Como futura oportunidade para trabalhos complementares, etapas adicionais no processo, como: validação, calibração e construção de base de dados poderiam ser aplicadas. Também agrega-se desenvolvimentos atrelado com o BIM.

Essa metodologia empregada, principalmente devido à tipologia do programa de mestrado no qual a pesquisa foi inserida (Mestrado Profissional), permite otimizar prazos, recursos e controle, para alcance dos objetivos.

Apesar de não ter sido possível a validação em caso real do modelo apresentado, representa uma promissora e útil metodologia para estudos preliminares e de viabilidade de obras aeroportuárias.

Ainda dentro da temática, para a elaboração desta dissertação foram seguidas as diretrizes da USP, segundo Funaro et al. (2016), no que tange a escrita, formatação e padrões de apresentação.

\subsection{INSERÇÃO DO TRABALHO}

Esse trabalho foi realizado dentro do Programa de Mestrado Profissional em Inovação na Construção Civil - CONSTRUINOVA, capitaneado pelo Departamento de Engenharia de Construção Civil da Escola Politécnica da Universidade de São Paulo.

O Mestrado Profissional é uma modalidade de pós-graduação stricto sensu, que enfatiza estudos e técnicas diretamente voltadas ao desempenho de um alto nível de qualificação profissional (CAPES, 2014).

Segundo Mingione (2016), dentro desse conceito, o programa no qual está inserido esse trabalho tem por objetivo a formação, em nível de pós-graduação, de profissionais atuantes no setor, oferecendo técnicas e instrumentos para utilização 
aplicada dos conhecimentos acadêmicos no exercício da inovação, em clara associação com o desenvolvimento profissional.

O Mestrado Profissional tem como objetivo contribuir para com o setor produtivo nacional no sentido de agregar um nível maior de competitividade e produtividade a empresas e organizações, sejam elas públicas ou privadas. $\mathrm{O}$ trabalho final do curso deve ser sempre vinculado a problemas reais da área de atuação do profissional-aluno e de acordo com a natureza da área e a finalidade do curso (CAPES, 2014).

Para esse autor, é a possibilidade de desenvolver uma inovação para aplicação em análises de viabilidade de futuros projetos de aeroportos no Brasil.

Dessa forma, este trabalho fica sob a linha de pesquisa denominada Tecnologia e Gestão da Produção na Construção Civil da Escola Politécnica da Universidade de São Paulo, que foca no desenvolvimento de tecnologias e ferramentas de gestão para resolução de problemas e aumento da competitividade das atividades do setor da construção civil.

\subsection{ESCOPO DO TRABALHO}

A infraestrutura de pavimentação aeroportuária tem como objetivo possibilitar, com segurança, as manobras de pouso, decolagem, movimento e estacionamento de aeronaves.

As superfícies pavimentadas destinadas às movimentações das aeronaves estão no "lado ar" do aeroporto, de acesso restrito ao público, e compõem as pistas de pouso e decolagem, pistas de táxi e pátios de estacionamento de aeronaves (DURAN, 2015).

Com isso, fica estabelecido que o escopo desse trabalho é apresentar um formato para estimar os custos diretos de construção de tais superfícies presentes nos aeroportos (Pista de pouso e decolagem, Pistas de táxi e Pátio de estacionamento de aeronaves). Fica também delimitado que o modelo desenvolvido refere-se a aplicações para aeroportos domésticos brasileiros e que análises referentes a terraplenagem e movimentos de terra não foram consideradas, devido à complexidade 
desse assunto e a ampliação que seria imposta à agenda do presente trabalho, já bastante preenchida.

Como embasamento, embora afeto e aplicado a outra cadeira de conhecimento da construção civil, alguns conceitos do Modelo de Fatores, desenvolvido pelo pesquisador $\mathrm{H}$. Randolph Thomas, foram empregados como fundamento no desenvolvimento desse trabalho, no sentido de dividir em partes o empreendimento (elementos) e de iniciar a formulação de fatores; no caso, esses fatores são os que maior impacto tem no custo de construção das superfícies pavimentadas destinadas às operações de aeronaves em aeroportos. Com essas definições, estabelece-se o escopo a ser abrangido pelo trabalho.

\subsection{OBJETIVOS}

O objetivo geral do trabalho é apresentar um modelo para estimativa dos custos de construção, das superfícies pavimentadas para operação de aeronaves em aeroportos, com base em informações preliminares sobre sua concepção e implantação, sendo uma ferramenta importante para análises sobre investimentos para construção de empreendimentos aeroportuários.

Como objetivos específicos, apresentam-se:

- A consolidação da revisão da literatura sobre aeroportos (tratando sobre aspectos construtivos das superfícies pavimentadas) e sobre custos de produção de obras de construção civil, com viés na pavimentação aeroportuária;

- Definição e análise dos fatores que apresentam maiores impactos nos custos de construção dos elementos tratados - Pista de pouso e decolagem, Pistas de táxi e Pátio de estacionamento de aeronaves de aeroportos brasileiros. 


\subsection{ESTRUTURA DA DISSERTAÇÃO}

A dissertação foi dividida em sete capítulos. Na sequência é apresentado, brevemente, o conteúdo de cada capítulo.

- Capítulo 1: introdução mostrando a importância do transporte aéreo para o Brasil e o uso de estimativas de custos para as obras de engenharia envolvidas no projeto de aeroportos. A justificativa, ressaltando a relevância do trabalho, metodologia empregada, inserção do mesmo e os objetivos, completam essa parte.

- Capítulo 2: apresenta a revisão da literatura dos conceitos trabalhados. Expõe definições e posicionamento sobre o estado de conhecimento quanto ao assunto estimativa de custos na construção civil. Contempla, ainda, a reunião de síntese da literatura que embasa o conhecimento sobre as partes e componentes fundamentais de um aeroporto. Como escopo principal do trabalho, as superfícies pavimentadas para operações de aeronaves em aeroportos são apresentadas mais detalhadamente, bem como conceitos sobre pavimentação aeroportuária.

- Capítulo 3: apresenta a conceituação da modelagem paramétrica, eleita como base para o modelo desenvolvido. Assuntos afetos aos modelos paramétricos são explorados, como: procedimentos para emprego da modelagem paramétrica, as dificuldades de uso e conceitos de estatística envolvidos.

- Capítulo 4: apresenta a caracterização dos componentes do sistema aeroportuário brasileiro. Uma série de aeroportos brasileiros é caracterizada e, partir dessas informações, são tecidas avaliações sobre a infraestrutura do parque de aeroportos típicos brasileiros. Também são caracterizadas as frotas e aeronaves das principais companhias aéreas brasileiras, com o intuito de formatar o conjunto de aeronaves mais empregado nas operações áreas domésticas no Brasil. 
- Capítulo 5: através da modelagem paramétrica e das parametrizações apresentadas, um modelo foi desenvolvido para estimar os custos de construção das superfícies que formam o escopo desse trabalho. Apenas com informações preliminares, empregando o modelamento proposto, é possível analisar a viabilidade de um determinado empreendimento e comparar possibilidades.

- Capítulo 6: dedica-se a apresentar a aplicação propriamente dita do modelamento desenvolvido, através de exemplificações. Apresenta quadro sinóptico que resume todo o esforço envolvido na elaboração do trabalho.

- Capítulo 7: constatações são tecidas no sentido de comprovar o alcance da proposta descrita nos objetivos do trabalho apresentados no Capítulo 1, bem como breves análises dos resultados da pesquisa e da aplicação do modelamento paramétrico. Apresenta, também, sugestões para trabalhos futuros que desenvolvam os estudos elaborados e apresentados. 


\section{REVISÃO DA LITERATURA}

\subsection{CUSTOS EM OBRAS DE CONSTRUÇÃO CIVIL}

O levantamento do custo de um empreendimento é uma das primeiras preocupações no que diz respeito à tomada de decisão quanto à realização ou não do mesmo. É neste momento que se estima o montante a ser investido e, até mesmo, definem-se as especificações para o produto.

Mattos (2006) indica que, do ponto de vista do proprietário, cotação de insumos, percentual de perdas e produtividade de equipes, por exemplo, não são preocupações imediatas. Ele está mais preocupado com o montante do custo do empreendimento e como esse montante será desembolsado ao longo do tempo.

Destaca-se, então, a necessidade de se conhecer o custo da construção antes da elaboração de seus projetos detalhados. As estimativas cumprem um importante papel na construção civil, pois estes podem ser consideradas como ferramentas básicas e necessárias para o gerenciamento da construção, sendo peças imprescindíveis para o estudo de viabilidade, planejamento e programação de um empreendimento (LOSSO, 1995).

Em linhas gerais, as estimativas de custo têm sua aplicação ligada à avaliação dos ônus para a execução de uma construção e, deste modo, à determinação do valor total a ser financiado ou contratado e à viabilidade do projeto.

Discutindo a questão semântica do custo, uma vez que sua definição é relevante para o entendimento das terminologias, Franchi (1991) o define como uma medida de sacrifícios, sob a forma de trabalho ou materiais gastos na produção de um bem.

Dessa forma, o custo de um empreendimento é normalmente abordado como sendo uma medida determinística, um gasto relativo a um bem ou serviço utilizado na produção de outros bens ou serviços. 
Utilizando as definições apresentadas por Kato (2013), uniformiza-se a nomenclatura e conceito sobre gastos (consumo genérico de bens e serviços por meio de desembolso passado, presente ou futuro) que podem ocorrer em empreendimentos da construção civil.

Os custos podem ser classificados em diretos e indiretos, segundo Parisotto (2003):

- Custos diretos são aqueles diretamente apropriados para execução dos produtos (materiais, mão de obra e equipamentos), bastando haver uma medida de consumo;

- Custos indiretos são aqueles provenientes do somatório dos custos dos materiais e serviços necessários, entretanto, não aplicados diretamente na realização de um empreendimento e, desta forma, não sendo proporcionais à quantidade de serviço executada.

O conhecimento dos custos de uma empresa é de capital importância para o gerente, principalmente em empresas de engenharia, onde acontecem continuamente e em valores expressivos; e o faturamento ocorre de forma discreta (ÁVILA; JUNGLES, 2001).

A execução de uma obra acaba sendo fundamental para a concretização de um produto e demanda grande esforço financeiro, o que exige grande necessidade de controle e atenção aos custos e prazos (FREITAS, 2017).

Desta forma, o processo orçamentário é um sistema de trabalho que envolve toda a empresa e tem por objetivo prever os custos a serem incorridos para realização de um determinado empreendimento.

\subsubsection{Emprego da estimativa de custos em obras de construção civil}

Estimativa de custo é uma forma de traduzir os custos de execução de um projeto. Sua qualidade é medida em termos de precisão, ou seja, de sua aproximação com o custo real incorrido. 
A atividade de estimar custos é bastante antiga e sua importância inquestionável, uma vez que o custo de um empreendimento é fator limitante para sua definição e implementação (ANDRADE; SOUZA, 2003).

Serve para dar uma ordem de grandeza ao empreendimento, sendo uma avaliação expedida com base em custos históricos e comparação com projetos similares (MATTOS, 2006).

Carr (1989) considera uma estimativa como sendo uma previsão, uma aproximação, que produz informações para decisões empresariais e se apresenta como substituto para a avaliação real, quando esta não é viável física ou economicamente. Pode ser considerada acurada quando é suficientemente próxima ao valor real, de modo que as decisões tomadas com base na mesma são similares àquelas fundamentadas num ambiente real, caso sua caracterização fosse possível.

O levantamento de custo é um processo alimentado por um conjunto de informações e fornece um resultado não determinístico - não implica necessariamente na elaboração de um orçamento.

Para Losso (1995), a estimar os custos não possui o objetivo de precisar o valor de uma determinada obra e sim de apresentar um intervalo no qual, dependendo das considerações tomadas como parâmetros, o custo do empreendimento esteja compreendido.

No desenvolvimento de uma estimativa de custos, há dois tipos de incertezas que podem ocorrer, prejudicando a precisão (UNITED STATES OF AMERICA, 1995):

- Incertezas relacionadas a problemas presentes no método utilizado, resultante da omissão de variáveis de custo, má especificação de coeficientes e relações matemáticas, além da falta ou inconsistência dos dados históricos utilizados;

- Outras incertezas advindas da dificuldade em se definir o desempenho a ser alcançado dentro da rotina de produção, em virtude de acontecimentos imprevistos ligados aos recursos e programação do processo de produção.

Os custos de uma construção são apurados em várias etapas. Antes, durante e depois da elaboração dos projetos, dependendo do propósito pelo qual estão sendo 
produzidas. O método utilizado para obter o custo da construção está relacionado com o estágio de detalhamento do projeto, com o tempo disponível para análise e com o uso a que se destina.

Entretanto, os métodos invariavelmente contam com os dados históricos de projetos anteriores, os quais compreendem as composições, os quantitativos e as relações entre as variáveis (OLIVEIRA, 1990).

Dentre os métodos de estimativas existentes, alguns são mais complexos, fundamentados em características geométricas definitivas, como é o caso do orçamento discriminado, enquanto outros se fundamentam em características mais simples e oferecem uma maior velocidade no processamento dos resultados, embora menos precisos (OTERO, 2000).

Sabe-se também que as atividades de construção são processos inerentemente incertos e, por consequência, há um limite para a exatidão que pode ser alcançada dentro dos métodos de prognóstico de custos (LICHTENBERG, 1980). Na fase inicial de projetos de construção civil, os elementos componentes do custo não se encontram suficientemente detalhados, dificultando levantamentos mais minuciosos dos custos de um determinado empreendimento.

Leusin (1993) afirma que a sistemática de estimativa de custo empregada no setor de construção civil se caracteriza por reduzir objetos diferenciados a médias históricas de consumo de material e trabalho por unidade de medida. A precisão deste sistema tende a ser razoável para situações em que existe um padrão construtivo.

Entretanto, essas comparações nem sempre são confiáveis, sobretudo porque os preços de mercado são muitas vezes voláteis. Essas estimativas devem ser consideradas como ordens de grandeza, não como certezas matemáticas (PIKETTY, 2014).

Desta forma, o ato de estimar de custos não tem o objetivo de precisar o valor de uma determinada obra, e sim apresentar uma aproximação na qual o custo do empreendimento esteja bem representado, com um grau de precisão aceitável para o momento em que se utiliza a informação (LOSSO, 1995). 
Oliveira (1990 apud ASHWORTH; SKITMORE, 1983) concluíram que o nível geral de precisão de custos estimados em estágios iniciais teria uma variação da ordem de $15 \%$ a $20 \%$ em relação aos custos incorridos na realidade. Verifica-se, com isso, que as informações do projeto detalhado teriam efeito limitado sobre a precisão.

Segundo Souza (2006), no que se refere ao estudo de viabilidade, conhecer determinados parâmetros confere maior confiabilidade à decisão do empreendedor. A Figura 5 ilustra a sequência de etapas que compõem um empreendimento da construção civil.

Durante a primeira das etapas mostradas, o empreendedor tece análises também sobre a viabilidade econômica de determinado empreendimento. A disponibilidade de materiais locais, equipamentos e processos a serem empregados, exigências de transporte diversos, mão de obra local disponível, indicam alguns dos itens levados em consideração nessa etapa que influenciam os custos de construção.

Figura 5 - Etapas de um empreendimento da construção civil

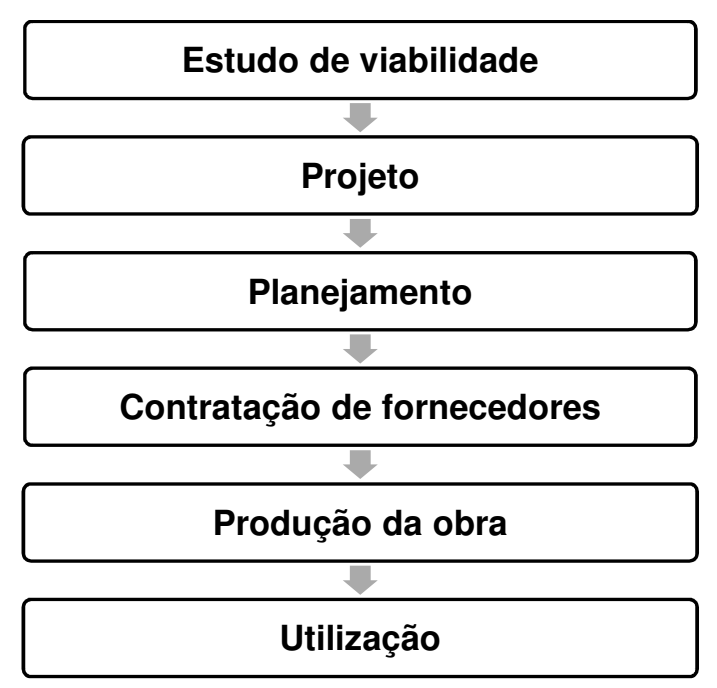

Fonte: SOUZA (2006)

Nesse momento inicial, podem-se comparar partidos arquitetônicos e tecnológicos alternativos, não se esquecendo de fatores que envolvem produtividade e consumo de recursos (materiais, mão de obra e equipamentos). Ainda, segundo Silvestri (2015), subsidia a análise de métodos construtivos, escolha de boas práticas e prazos de execução. 
Também é necessário entender que a engenharia se relaciona com a natureza, aplicando materiais, métodos e processos reais, todos com variabilidade inerente, que resulta em incerteza do projeto como um todo (AGOPYAN, 2019).

\subsubsection{Métodos para estimativa de custos em obras de construção civil}

Inicialmente, vale ressaltar que toda essa parte da revisão da literatura, foi adaptada, na medida do possível (da construção civil de edificações), ao caso estudado neste trabalho, que são as superfícies pavimentadas para operação de aeronaves em aeroportos, visto a falta de referências e trabalhos desenvolvidos que tratem do assunto de forma específica.

Segundo Lima (2000), o processo orçamentário envolve a determinação dos gastos necessários à realização de um projeto, de acordo com o plano de execução préestabelecido, devendo satisfazer os seguintes objetivos:

- Definir custo de execução de cada serviço;

- Constituir-se em documento contratual, servindo de base para o faturamento;

- Servir de referência na análise de investimentos;

- Fornecer informações para o desenvolvimento de coeficientes técnicos confiáveis, tornando a empresa mais competitiva.

Para Lichtenberg (1980), cada etapa do ciclo do processo de construção mantém diferentes tipos de decisões a serem tomadas, sendo exigidos níveis diferenciados de exatidão nos resultados de estimativas utilizadas em cada uma destas etapas.

Quando se empregam modelos físicos complexos e matemática sofisticada, fica a falsa impressão de que a engenharia é uma ciência exata; no entanto, os modelos são detalhados e os cálculos precisos, mas embasados em dados não tão exatos (AGOPYAN, 2019). 
Segundo Parisotto (2003), destaca entre os métodos para estimativa de custos, na construção civil: Custo Unitário Básico (CUB) e Relação Linear entre o custo total e a área de construção.

Dentre as vantagens para utilização CUB, destaca-se o fato de relacionar o custo de construção com o metro quadrado, ou seja, relaciona o custo com uma das variáveis geométricas a que o usuário atribui maior importância no momento da decisão da construção de um empreendimento (LOSSO, 1995).

O CUB, cuja origem remonta da publicação da Lei no 4.591 de 16 de dezembro de 1964, geralmente apresenta seu uso aliado ao de publicações específicas, como Tabelas de composições de preços (publicadas por editoras especializadas) ou, por exemplo o Sistema Nacional de Pesquisa de Custos e Índices da Construção Civil SINAPI.

Segundo Losso (1995), o segundo método, relação linear histórica entre o custo total e a área de construção, faz uso de dados referentes a projetos da própria empresa e tende a apresentar uma maior aproximação dos valores realmente incorridos do que acontece com o Custo Unitário Básico, procedimento mais generalista e, assim, menos representativo quanto aos produtos específicos da construtora em questão.

Diversos autores apresentam o método mais tradicional para se estimar o custo de uma construção que é custo por $\mathrm{m}^{2}$; no entanto, usar um valor médio para este indicador como prognóstico para uma próxima obra pode levar a um valor impreciso de custo (KATO, 2013).

Entretanto, na etapa de projeto, as informações disponíveis para estudos e análises estão mais atreladas aos requisitos, especificações e necessidades dos usuários do que ao processo construtivo.

Parisotto (2003) cita que a alternativa mais eficiente para estimativa preliminar de custos é a comparação entre índices que representem uma parcela significativa desses custos, uma vez que a comparação entre alternativas de projeto por meio de orçamentos completos se apresenta não apenas trabalhosa mas também, por vezes, não possível, já que ainda não se dispõe dos projetos complementares para realizar o levantamento completo dos serviços a serem executados. 
Para que se possa viabilizar uma estimativa de custos, a melhor maneira é dividir o empreendimento, em "partes" funcionais de maior influência nos custos, seguindo o indicado por Mascaró (1998).

Otero (2000) argumenta que as decisões relacionadas em termos de acabamento e distribuição dos espaços, definem as diferenças em termos de custo para o empreendimento e são dependentes da estratégia planejada.

O cálculo de custo envolve incertezas pelo simples fato de ele ser feito em tempo anterior à realização do empreendimento. Diversas premissas devem ser adotadas antecipadamente e que deverão ser acompanhadas durante todo o processo de projeto e construção.

Segundo Marchiori (2009), como o prognóstico é feito em uma etapa onde se possuem poucas informações acerca do empreendimento, para a elaboração, é necessário utilizar parâmetros vindos de projetos similares feitos anteriormente.

Alguns atributos merecem atenção quando se elaboram estimativas de custos, visando efetividade e acurácia. Dentre os principais atributos, destacam-se (KIM; AN; KANG, 2004):

- Precisão;

- Facilidade no uso da ferramenta;

- Oferecimento do valor de custo rapidamente;

- Poder se entender o processo utilizado, para verificar quais fatores podem variar e quais suas influências no custo prognosticado;

- Poder atualizar facilmente os dados que basearam a elaboração do método.

Considerando os atributos supracitados, esse trabalho buscou desenvolver um modelo que contemple os mesmos e permita obtenção de informações mais adequadas para estabelecer custos preliminares de construção, que balizem decisões sobre a viabilidade de determinado aeroporto. 
Dentro do ciclo de vida de um empreendimento, o estudo de viabilidade possui as etapas apresentadas na Figura 6. Cabe destacar que a etapa de simulação seria exatamente o propósito da modelagem que se pretende desenvolver neste trabalho. A partir das simulações para diferentes alternativas, o planejador pode escolher, comparar e analisar possibilidades.

Figura 6 - Etapas do processo de análise de alternativas

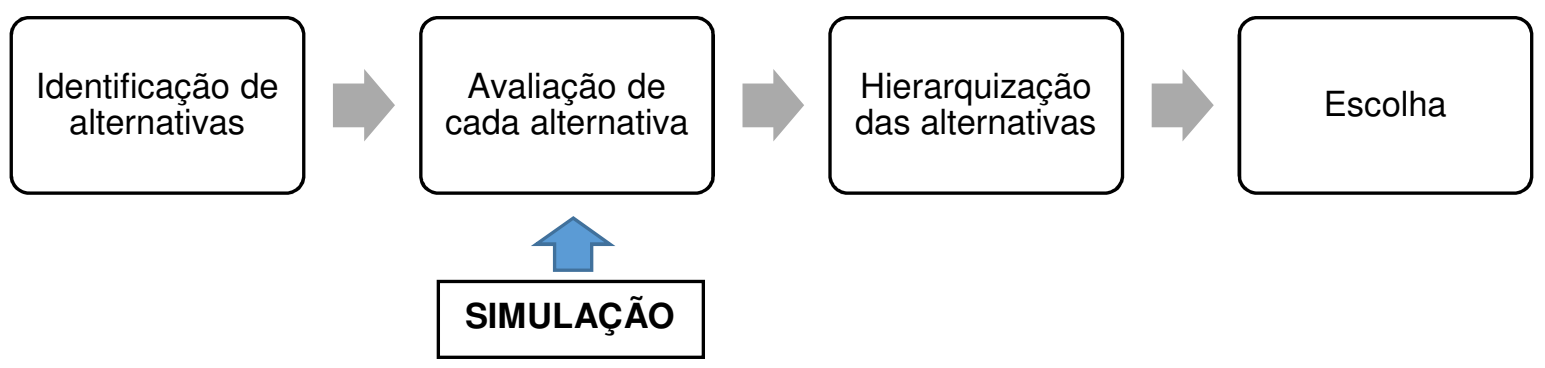

Fonte: Elaboração própria, com base em ROCHA LIMA (1985)

Existem ainda outras formas de estimar custos de projetos, apresentadas na sequência, segundo PMI (2018) e Mattos (2015):

- Estimativas por analogias;

- Ferramentas computadorizadas;

- Dimensões físicas: estima-se o custo através da utilização de um parâmetro físico característico da obra (comprimento, área, volume etc.).

- Unidades do produto final: baseia-se em dados históricos de projetos similares que permitam relacionar o custo total da obra com uma unidade de capacidade da edificação. Exemplos: num projeto de hotel - número de quartos, onde chega-se ao parâmetro custo por quarto; num estacionamento - número de vagas, onde chega-se ao parâmetro custo por vaga.

- Fator de capacidade: metodologia muito interessante quando se dispõe de uma grande quantidade de projetos similares, que permita a correlação entre custo e tamanho (capacidade). A Figura 7 ilustra graficamente essa metodologia, além de demonstrar a equação de correlação. No eixo das ordenadas são expressos os custos. No eixo das abscissas são expressas as capacidades. 
Figura 7 - Estimativa de custos através do Fator de capacidade

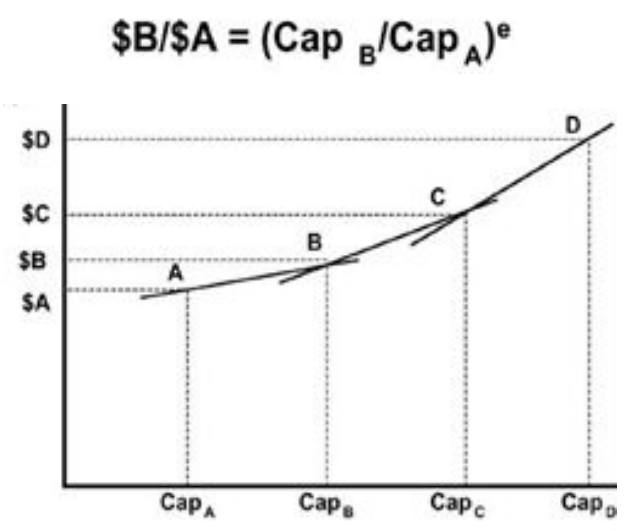

Fonte: MATTOS (2015)

- Fator de proporcionalidade: empregado para o caso de obras industriais. O custo de uma planta industrial é obtido de forma expedita pela multiplicação de um fator pelo preço dos equipamentos da fábrica.

- Modelagem paramétrica: requer o tratamento matemático de várias funções para se chegar a uma fórmula que permita inferir o custo de um empreendimento.

A estimativa de custo é por natureza uma aproximação. Nela são aplicados métodos conceituais, em que variáveis são usadas no modelo de predição, e o que se faz é atrelar dados históricos a algum parâmetro relacionado com o projeto em questão (área construída, capacidade, número de assentos, extensão etc.) (MATTOS, 2015).

Já no orçamento, ao contrário, o que se faz é um cálculo determinístico, ou seja, medidas diretas de subconjuntos do produto final são utilizadas para determinação do custo provável de sua execução.

\subsubsection{Conceitos relacionados a custos na construção civil}

Ressalta-se, novamente, a importância da diferenciação do significado de preço e custo, itens muitas vezes mal interpretados nas análises preliminares sobre viabilidade de empreendimentos. 
Para composição do preço, deve-se considerar o valor dos materiais envolvidos, a mão de obra para execução, a eventual compra ou locação de equipamentos, além dos encargos sociais que incidem sobre a mão de obra e o Budget Difference Income (BDI), em livre tradução - Benefícios e Despesas Indiretas.

Mattos (2006) define composição de custos como "uma tabela que apresenta todos os insumos que entram diretamente na execução de uma unidade do serviço, com seus respectivos custos unitários e totais".

O orçamento facilita a seleção dos processos a serem padronizados, estabelece um nível de custos para os serviços que merecem maior atenção (LI; XIANYI; XIN, 2012). Permite, ainda, montar uma curva $A B C$ que hierarquiza os serviços de acordo com um critério estabelecido, que pode ser de custo, consumo de mão de obra, materiais entre outros.

\subsection{AEROPORTOS - ENTENDIMENTO DO PRODUTO}

Um aeroporto é componente fundamental do sistema aeroportuário, exigindo devido projeto para acomodar ampla variedade de passageiros e aeronaves. Embora os conceitos fundamentais sejam aplicáveis a todo e qualquer aeroporto, não existem no mundo dois terminais absolutamente idênticos (YOUNG; WELLS, 2014).

Desde o seu início, nos primórdios do século XX, a aviação civil tornou-se uma das indústrias mais fascinantes, importantes e complexas do mundo. Dentro do sistema da aviação, os aeroportos são considerados a espinha dorsal desse modal de transporte mundial e recebe crescente importância no século XXI (HORONJEFF et al., 2010).

Como definição, um aeroporto pode ser considerado uma instalação complexa da rede de transporte, projetada para atender aeronaves, passageiros e cargas. Cada um desses agentes é atendido por diferentes componentes do aeroporto (YOUNG; WELLS, 2014). 
A Figura 8 ilustra o esquema básico das principais partes de um aeroporto, independentemente do porte. Todos os aeroportos que recebam operações comerciais possuem, no mínimo, as partes ilustradas.

Figura 8 - Partes básicas de um aeroporto

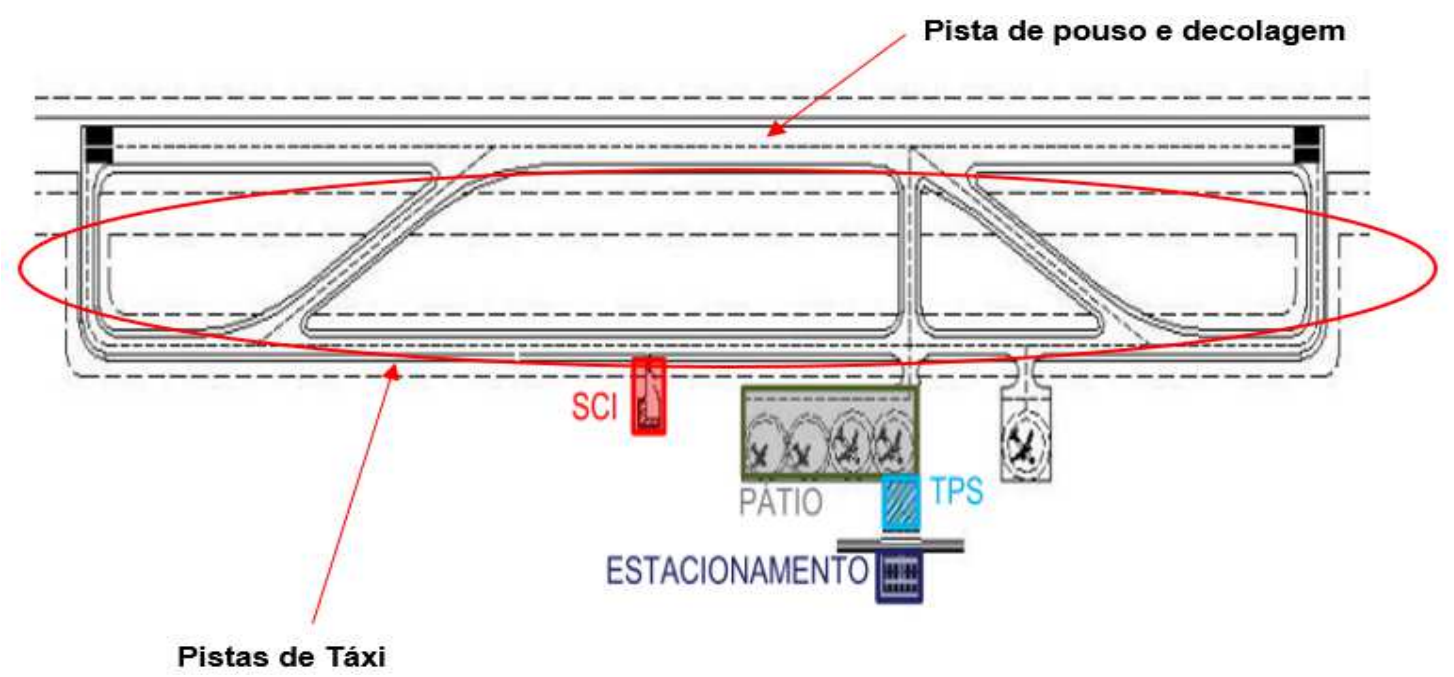

Fonte: BRASIL (2015a)

Onde se veem:

- Seção de Combate a Incêndio (SCI) - responsável por atender, em todo o sítio aeroportuário, ocorrências envolvendo as operações aéreas. O projeto dessa instalação é diretamente proporcional às aeronaves que serão operadas no aeroporto, vide ANAC (2019a);

- Pátio de estacionamento de aeronaves (PÁTIO) - área empregada para estacionamento de aeronaves, para as operações de embarque e desembarque de passageiros, bagagens e cargas;

- Edifício Terminal de Passageiros (TPS) - edificação onde os passageiros e bagagens são processados, visando embarque ou desembarque. Nessa edificação serviços acessórios, como lanchonetes, lojas, as próprias companhias aéreas e órgãos envolvidos na rotina aeroportuária, também são instalados;

- Pista de pouso e decolagem - superfície pavimentada retangular, preparada para os pousos e decolagens de aeronaves (ANAC, 2018b); 
- Pistas de táxi - conhecidas mais amplamente por sua denominação na língua inglesa (taxiways), segundo ANAC (2018b), são superfícies disponibilizadas num aeroporto para permitir movimentação segura e rápida de aeronaves entre a Pista de pouso e decolagem e posição de estacionamento;

- Estacionamento para veículos dos usuários (ESTACIONAMENTO) dimensionado para apresentar uma quantidade de vagas para acomodação dos veículos dos usuários (passageiros, visitantes, funcionários do aeroporto, órgãos públicos e companhias aéreas).

Verifica-se que, para a composição de um aeroporto, diversas partes que incluem obras de construção civil são necessárias e apenas com a junção de todas essas partes é que se tem o empreendimento completo para operação. Com isso apresentase como um projeto que envolve muitas disciplinas, desde sua concepção, construção e, principalmente, em sua operação.

Pensando-se no dimensionamento de um aeroporto, é interessante uma contextualização global sobre o empreendimento aeroportuário antes de focar-se no título e escopo desse trabalho. Para isso seguindo a literatura especializada, é interessante e didático separar os componentes em "Lado Ar" e "Lado Terra", conforme ilustrado na Figura 9.

Figura 9 - Componentes de um aeroporto

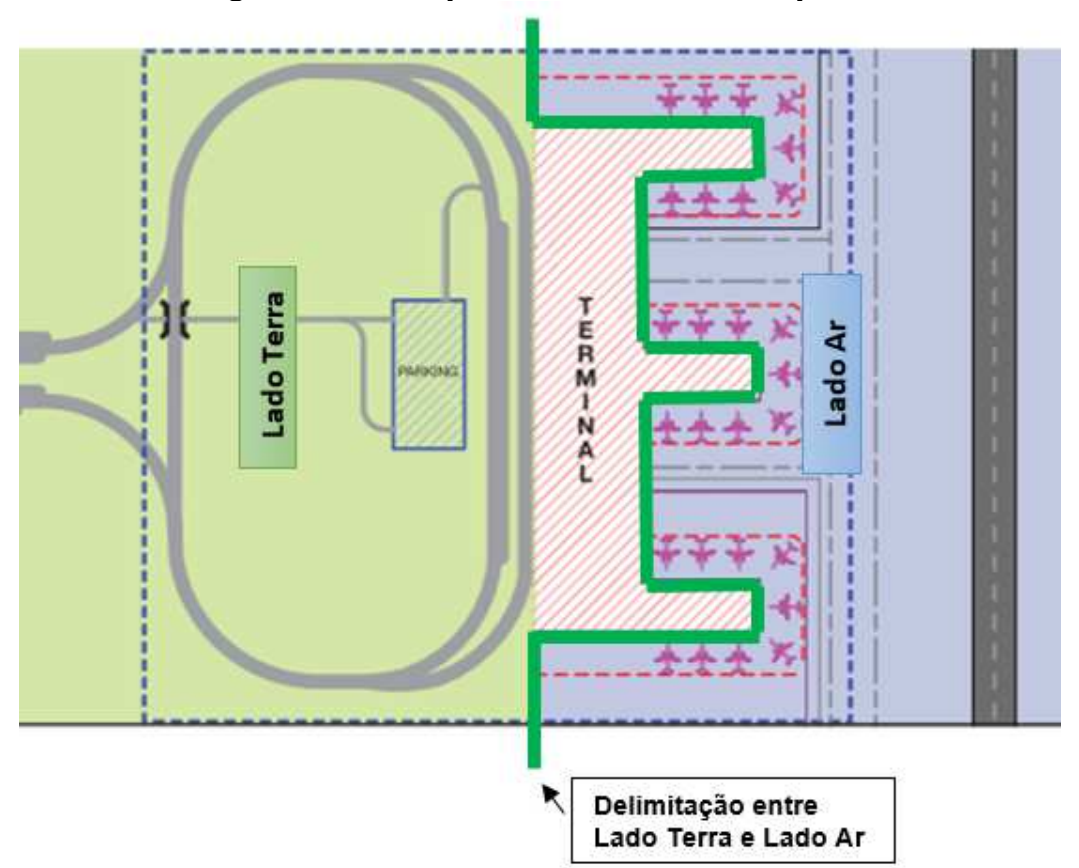

Fonte: ACRP (2010) - Adaptado 
Os componentes do Lado Ar são planejados e administrados para acomodar o movimento de aeronaves, em suas operações de chegada e partida. São componentes diretamente voltados ao voo e incluem as instalações físicas para operações das aeronaves. Os componentes do Lado Terra são planejados e administrados para acomodar o movimento de veículos terrestres, passageiros, bagagens e cargas (YOUNG; WELLS, 2014).

Essa divisão é a mais comumente empregada, na área aeroportuária, pois separa, de forma lógica, os componentes de um aeroporto. Na sequência são descritas as principais partes que compreendem obras de construção civil de cada "lado".

Pelo "Lado Ar", tem-se:

- Pátio de estacionamento de aeronaves: área empregada para estacionamento de aeronaves durante as operações de embarque e desembarque. Seu dimensionamento visa atender a ocupação, na hora-pico de projeto, pelas aeronaves.

Cada aeronave considerada em projeto possui um "envelope" correspondente a sua área de estacionamento e circulação, adicionada às necessidades de atendimentos de serviços de solo (reabastecimentos, drenagem de fluidos sanitários das aeronaves, abastecimento com itens de comissárias, checagens de equipes de manutenção e despacho operacional).

- Pista de pouso e decolagem: superfície retangular preparada para as operações de decolagens e pousos das aeronaves nos aeroportos. Trata-se do maior e mais importante elemento da infraestrutura do lado ar do aeroporto.

- Pistas de táxi: tem a função de conduzir as aeronaves que terminaram o procedimento de pouso em direção ao pátio ou seu contrário, visando posicionar-se para decolagem.

Pelo “Lado Terra”, tem-se:

- Edifício Terminal de Passageiros (TPS): apresenta as funções principais de processar passageiros e bagagens, fornecer as condições necessárias para 
embarque e desembarque de passageiros e facilitar a transição de um modo de transporte para outro (MEDEIROS, 2004).

Para o dimensionamento é necessário conhecer as demandas especificadas para processamento de passageiros, seja embarcando, desembarcando ou em processo de check-in, visando definir três principais parâmetros: tempo de processamento, número médio de acompanhantes por passageiro e relação de área por usuário (implicação do nível de serviço oferecido).

Os TPS, além considerar os itens supracitados, podem apresentar-se sob diversas formas, no que tange ao conceito. A Figura 10 apresenta as principais concepções de distribuição horizontal para os terminais de passageiros. Vale um breve apresentação desses conceitos, na sequência apresentada, segundo Silvestri (2015).

Os terminais lineares apresentam uma longa edificação horizontal, que permite ampliações para ambos os lados, com as aeronaves estacionadas na frente do terminal, no lado ar. Os terminais com conceito píer, apresentam as aeronaves estacionadas ao longo de corredores conectados a uma edificação principal.

Já os terminais com conceito satélite e transporter, são indicados para demandas maiores de passageiros a serem processados, acima de 1 milhão de passageiros/ano. No primeiro, as aeronaves são estacionadas ao redor de uma edificação central (o satélite) e no segundo as aeronaves são estacionadas em posições remotas em relação a edificação do TPS; os passageiros são transportados via ônibus até a aeronave.

Figura 10 - Conceitos de distribuição horizontal aplicáveis para TPS

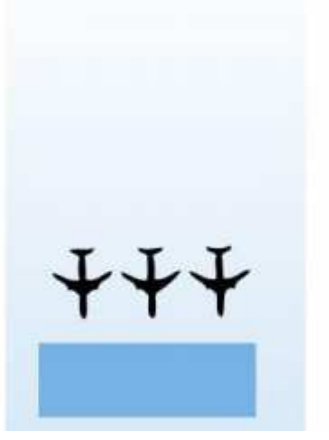

(a) Linear

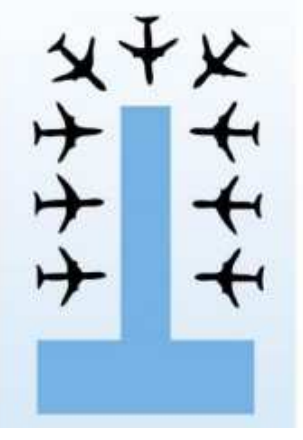

(b) Píer

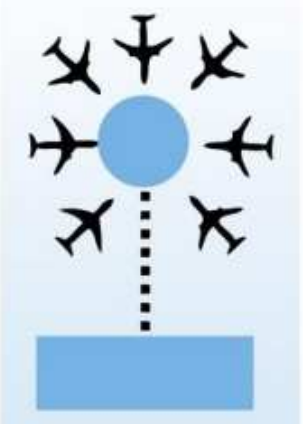

(c) Satélite

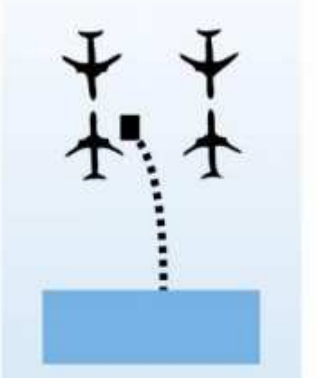

(d) Transporter

Fonte: Elaboração Própria, com base em FAA (2018) 
Uma análise complementar, que leva em consideração principalmente a demanda a ser atendida por um TPS, recai sobre a concepção vertical da edificação, vide Figura 11. Na edificação com um único pavimento, todo processamento é realizado no plano do Pátio de estacionamento de aeronaves, o que é técnica e economicamente viável para aeroportos destinados a demandas relativamente menores (até por volta de 1.000.000 de passageiros/ano); já nos terminais com dois pavimentos, os processamentos de embarque e desembarque são realizados em pavimentos diferenciados, sendo mais adequados para demandas maiores.

Figura 11 - Conceitos de distribuição verticais aplicáveis para TPS

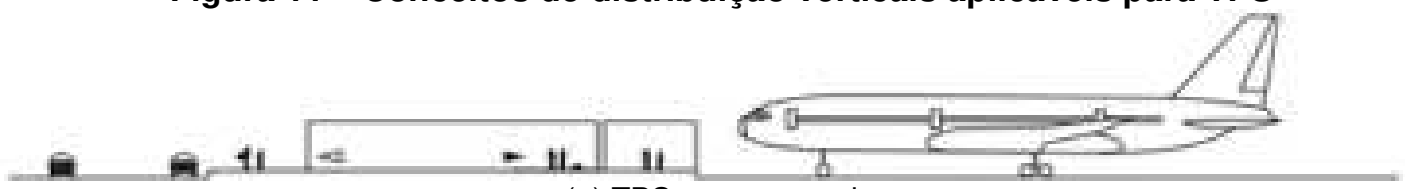

(a) TPS com um pavimento

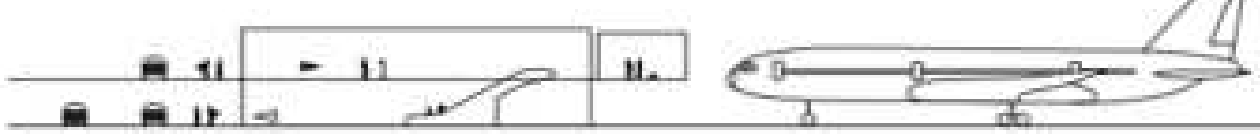

(b) TPS com dois pavimentos

Fonte: HORONJEFF et al. (2010) - Adaptado

Quanto ao dimensionamento das áreas de um TPS, diversos métodos podem ser verificados na literatura, desenvolvidos por diversos autores, operadores aeroportuários e autoridades de aviação civil em todo o mundo (MEDEIROS, 2004).

No entanto, devido à escassez de parâmetros nacionais para dimensionamento, Medeiros desenvolveu um amplo trabalho em 2004, propondo um novo método mais adequado para o dimensionamento de terminais de passageiros para aeroportos brasileiros, no qual considera características e condições de contorno peculiares à realidade do país.

Como se trata de um componente importante de um aeroporto, a relação entre recursos financeiros disponibilizados para um projeto e seus custos de implantação, segundo a IATA (2016), é classificada como um dos principais motivadores para se estabelecerem padrões de níveis de serviço de um terminal.

Cavaleiro (2017 apud CORREIA; WIRASINGHE, 2007) relaciona a adoção de valores de referência, como, por exemplo, área por passageiro e tempo de espera, no 
planejamento para dimensionamento da infraestrutura aeroportuária, visando embasar a tomada de decisões.

Quanto ao nível de serviço percebido, pode ser um método de classificação em níveis de qualidade para determinado item (IATA, 2016), enquanto que o nível de serviço oferecido é estabelecido por medidas quantitativas para determinados indicadores.

Até mesmo, segundo Cook e Goodwin (2008), a arquitetura atual da malha aérea 2, impacta o dimensionamento de um aeroporto. A Figura 12 apresenta a diferença entre a arquitetura de sistema de malha aérea ponto-a-ponto frente de sistema hub-andspoke ${ }^{3}$.

Figura 12 - Arquiteturas de sistemas de malhas aéreas

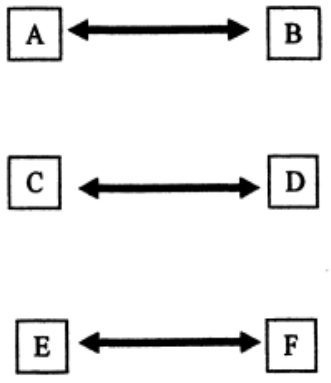

(a) Ponto-a-ponto

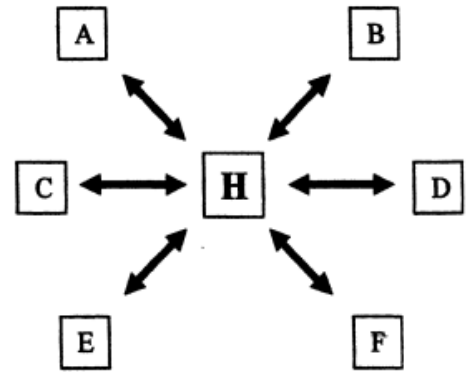

(b) Hub-and-spoke

Fonte: COOK; GOODWIN (2008)

$\mathrm{Na}$ Figura 12, as letras $\mathrm{A}$ a $\mathrm{H}$ representam localidades hipotéticas. Para uma melhor contextualização, nas ligações ponto-a-ponto, as localidades são ligadas diretamente sem escalas ou conexões (voos diretos), já nas ligações hub-and-spoke, as localidades são interligadas passando por um hub, fazendo com que os voos tenham uma escala, ao menos.

Faz-se interessante conhecer essas arquiteturas, uma vez que no primeiro sistema listado, mais empregado até meados da década de 90 do século XX, maior

2 Malha aérea: conjunto de itinerários que são cumpridos pelas companhias aéreas em períodos regulares.

${ }^{3}$ Conceito aplicado ao transporte aéreo que traduz um sistema no qual os passageiros viajam de aeroportos menores para um grande aeroporto para fazer viagens mais longas. 
infraestrutura física era necessária nos diversos aeroportos espalhados pelo país, visto que todos os aeroportos tinham que comportar basicamente a movimentação das mesmas aeronaves. Já no segundo sistema, apenas o hub acaba ficando responsável pela operação das grandes aeronaves e grandes demandas.

Uma análise das operações, nos Estados Unidos da América, apontou que as ligações ponto-a-ponto originalmente adequadas às companhias aéreas que operam nas regiões mais interiores, vem perdendo espaço para rotas clássicas que utilizam hub, devido aos menores custos, melhoria da eficiência e redução de custos trabalhistas para as companhias aéreas.

Cabe ainda ressaltar, sobre os TPS, que os aeroportos atuais são empreendimentos com objetivo de gerar lucro. Atividades comerciais, processamento de passageiros e despachos de aeronaves devem ser eficientes, para melhorar a satisfação dos usuários e aumentar o lucro (VOKÁC; LÁNSKÝ; SZABO, 2017).

O padrão de classificação do nível de serviço pode ser verificado sob duas óticas, segundo a IATA (2016): qualitativa, com uma comparação de A até F (Tabela 1) e quantitativa, na qual são estabelecidos valores de referência de áreas por passageiro (Tabela 2).

Tabela 1 - Nível de serviço (descrição qualitativa)

\begin{tabular}{cccc}
\hline \multirow{2}{*}{$\begin{array}{c}\text { Nível de } \\
\text { Serviço }\end{array}$} & Fluxo & Sistemas & \\
\cline { 2 - 4 } & Livre & Atraso & Conforto \\
\hline A & Estável & Muito pouco & Excelente \\
\hline B & Estável & Aceitável & Alto \\
\hline C & Instável & Aceitável por pouco tempo & Adequado \\
\hline D & Instável & Inaceitável & Inadequado \\
\hline E & Colapso do sistema & Inaceitável & - \\
\hline F & & &
\end{tabular}

Fonte: IATA (2016)

$\mathrm{Na}$ Tabela 1, entende-se como fluxo livre, uma cadência na movimentação de usuários no TPS, sem geração de pontos de concentração. Já na situação de fluxo estável, concentrações são admitidas, porém sem comprometer a circulação. Quanto ao fluxo instável, filas e aglomerações dificultam o processamento de passageiros. 
Os valores indicados para as áreas necessárias, segundo os níveis de serviço, na Tabela 2, são obtidos através de estudos e coleta de dados históricos, que são tabulados e baseiam-se em equações formuladas para essa finalidade.

Tabela 2 - Nível de serviço (descrição quantitativa)

\begin{tabular}{|c|c|c|c|c|c|c|}
\hline \multirow{2}{*}{ Ambiente } & \multicolumn{6}{|c|}{ Nível de Serviço (m²/usuário) } \\
\hline & A & B & C & D & $\mathbf{E}$ & $\mathbf{F}$ \\
\hline Área de fila para check-in & 1,8 & 1,6 & 1,4 & 1,2 & 1,0 & \multirow{5}{*}{$\begin{array}{c}\text { Sistema } \\
\text { em } \\
\text { colapso }\end{array}$} \\
\hline Circulação & 2,7 & 2,3 & 1,9 & 1,5 & 1,0 & \\
\hline Embarque & 1,4 & 1,2 & 1,0 & 0,8 & 0,6 & \\
\hline Desembarque & 2,0 & 1,8 & 1,6 & 1,4 & 1,2 & \\
\hline Área de inspeções & 1,4 & 1,2 & 1,0 & 0,8 & 0,6 & \\
\hline
\end{tabular}

Fonte: IATA (2016)

Seria possível, ainda, chegar a um nível de serviço superior ao "A"; no entanto, nesse caso resultaria em superdimensionamento do TPS e, por conseguinte, custo mais elevado e inicialmente já inadequado para um projeto racional (ASHFORD, 1988).

Visando ilustrar a questão dos níveis de serviço discutidos, a Figura 13 apresenta a ocupação dos espaços físicos num TPS, relacionando-os graficamente com os Níveis de Serviço, na figura denominado "LOS", que em inglês significa Level of Service.

Figura 13 - Comparação dos Níveis de Serviço

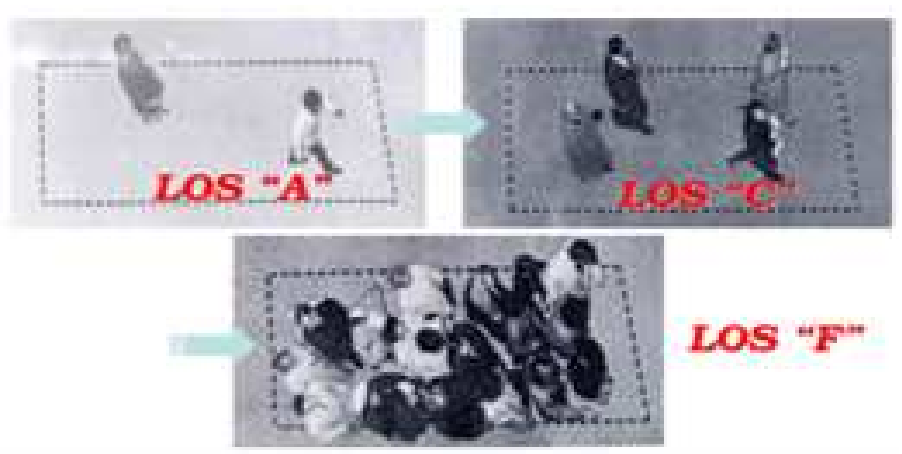

Fonte: CIVIL AVIATION AUTHORITY OF SINGAPORE (2018)

- Estacionamento de veículos: determina-se a área em função da quantidade de veículos a serem atendidos de passageiros, acompanhantes, visitantes e funcionários do terminal.

Esse componente sempre é controverso quanto ao dimensionamento, segundo a literatura mundial. As referências divergem sobre a quantidade de vagas a serem 
alocadas num estacionamento de veículos de um aeroporto, visto as especificidades, características e costumes de cada região ou país.

Mesmo considerando o crescente congestionamento nas rodovias e vias que dão acesso aos aeroportos, muitos operadores aeroportuários e governos locais e estaduais consideram o transporte em massa, com o uso de high-occupancy-vehicles (HOV) em seus planejamentos; no entanto, o transporte preferido de modo de acesso, pelo menos nos aeroportos localizados nos Estados Unidos da América, provavelmente continuará a ser o veículo privado (ACRP, 2008).

Com isso, alternativas mais conservadoras no sentido de alocar áreas maiores para estacionamento de veículos são as mais indicadas, o que requer maiores áreas em terrenos adjacentes ou áreas construídas de edifícios-garagens, que, por conseguinte, aumentam os custos de construção do empreendimento como um todo.

- Obras complementares de construção civil: proteção da área patrimonial dos aeroportos, terminais de carga nos aeroportos onde é prevista a movimentação e armazenamento de cargas, vias de acesso (externas ao aeroporto e internas para provimento de serviços relacionados a fiscalização, manutenção e recebimento e despacho de aeronaves), hangares (estruturas de grande porte destinadas a abrigar aeronaves e oficinas de manutenção de aeronaves) e construções acessórias (brigadas de emergência e combate a incêndios e infraestrutura para abastecimento de veículos e aeronaves).

Podem ainda ser citadas outras instalações que não são consideradas obras de construção civil, mas que compõem as instalações de um aeroporto: equipamentos e maquinários do TPS para processamento de passageiros e bagagens (aparelhagem para check-in, controle de acessos, manuseio e restituição de bagagens, controle e armazenamento de cargas); instrumentação de auxílio às operações aéreas (equipamentos para balizamento, orientação e processamento das aeronaves).

Uma visão sistêmica envolvendo as partes de um aeroporto e as operações aéreas também é interessante. A Figura 14 mostra aspectos deste relacionamento. 


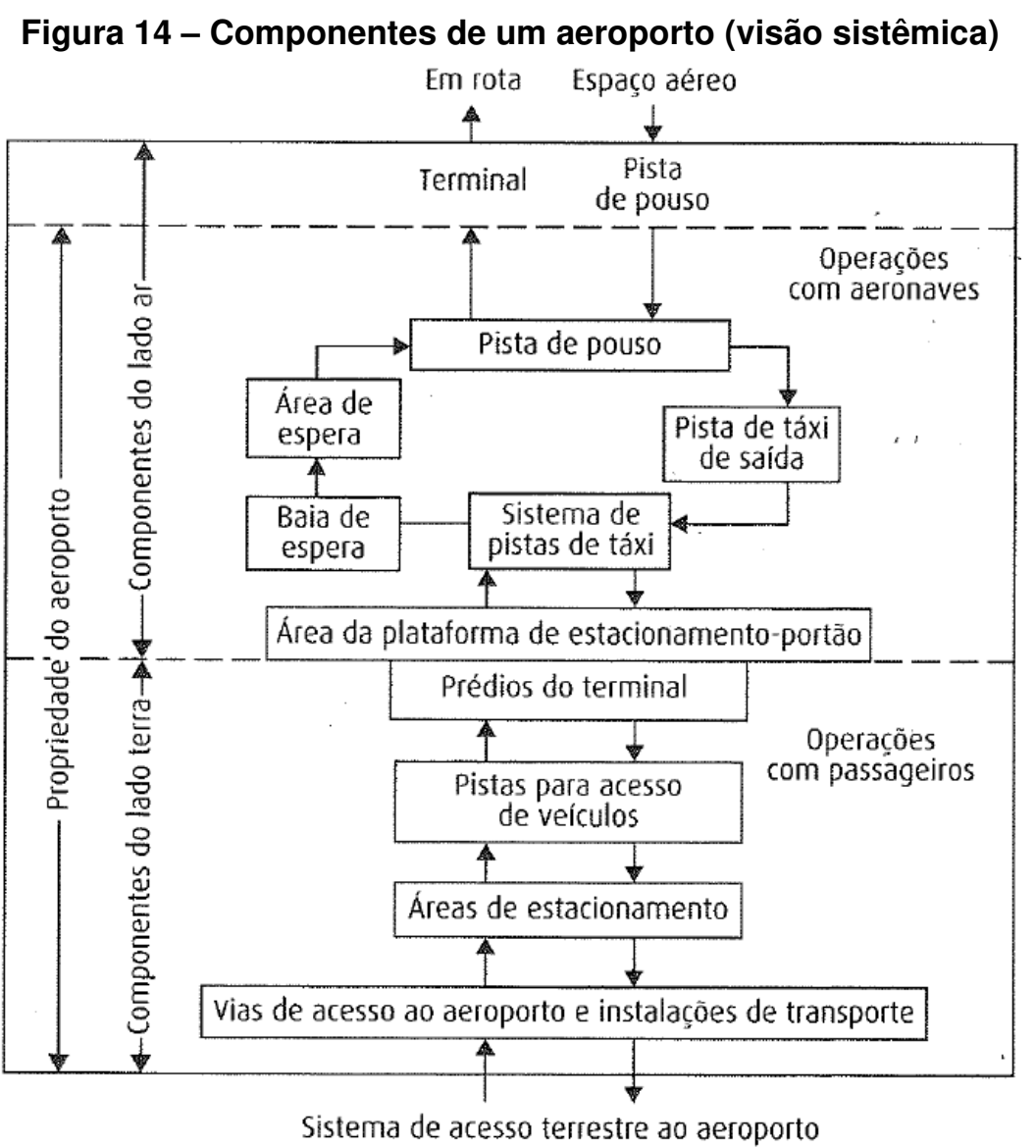

Fonte: YOUNG; WELLS, 2014

Por fim, os aeroportos são ainda divididos em três classes: internacional, domésticos e regionais (que operam para suprimento de demandas em determinada região do país). Cabe destacar que o porte de um aeroporto independe dessa classe, existindo aeroportos internacionais de porte médio e aeroportos domésticos de grande porte.

\subsection{SUPERFÍCIES PAVIMENTADAS PARA OPERAÇÃO DE AERONAVES}

Seguindo a delimitação do escopo desse trabalho, que busca o estabelecimento de um modelo para estimativa dos custos de construção das superfícies pavimentadas destinadas às operações das aeronaves em aeroportos, essa seção focará numa revisão dos itens pertinentes aos elementos que compõem essas superfícies.

Visando organização e para facilitar o entendimento, a Figura 15 ilustra os elementos pavimentados destinados às operações das aeronaves num aeroporto: Pista de pouso 
e decolagem (PPD), Pistas de táxi (taxiways; PTX) e Pátio de estacionamento de aeronaves (PEA).

Figura 15 - Elementos pavimentados destinados à operação de aeronaves em aeroportos

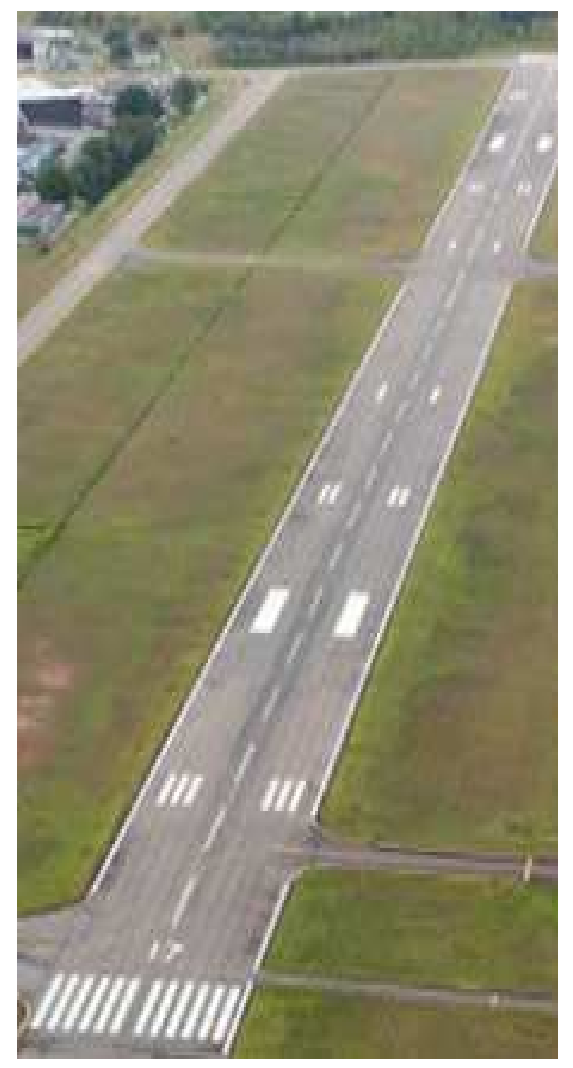

(a) PPD

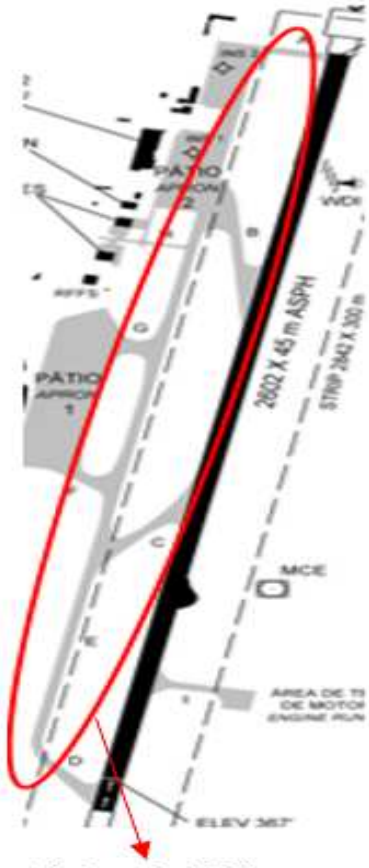

Pistas de Táxi

(b) PTX

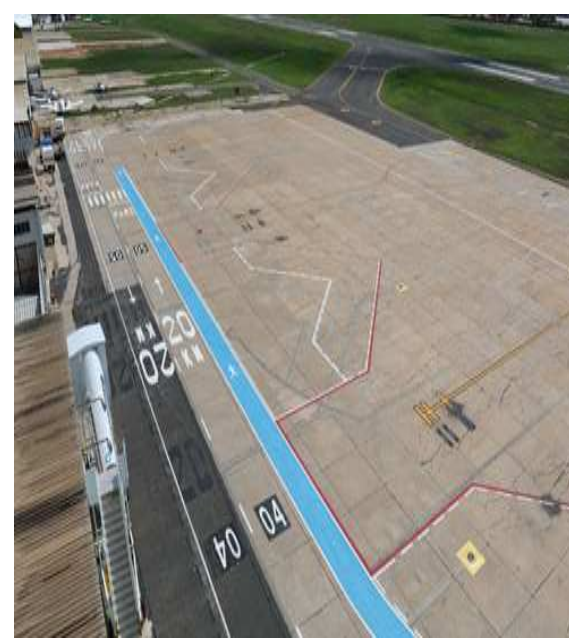

(c) PEA

Fonte: (a) e (c) INFRAERO (2019); (b) DECEA (2019) - Adaptado

Dentro de uma visão analítica, o conjunto dos elementos supracitados de um aeroporto pode ser descrito como uma somatória que apresenta as superfícies pavimentadas para operações das aeronaves como um todo em um empreendimento aeroportuário.

A Figura 16 exemplifica a visão analítica aplicada no desenvolvimento do trabalho; salienta-se que são compreendidos no estudo apenas as obras que envolvam a cadeira de construção civil, não sendo objetivo desse trabalho estimar custos de equipamentos e outros itens que compõem a infraestrutura aeronáutica. 
Figura 16 - Visão analítica aplicada às superfícies pavimentadas para operação de aeronaves

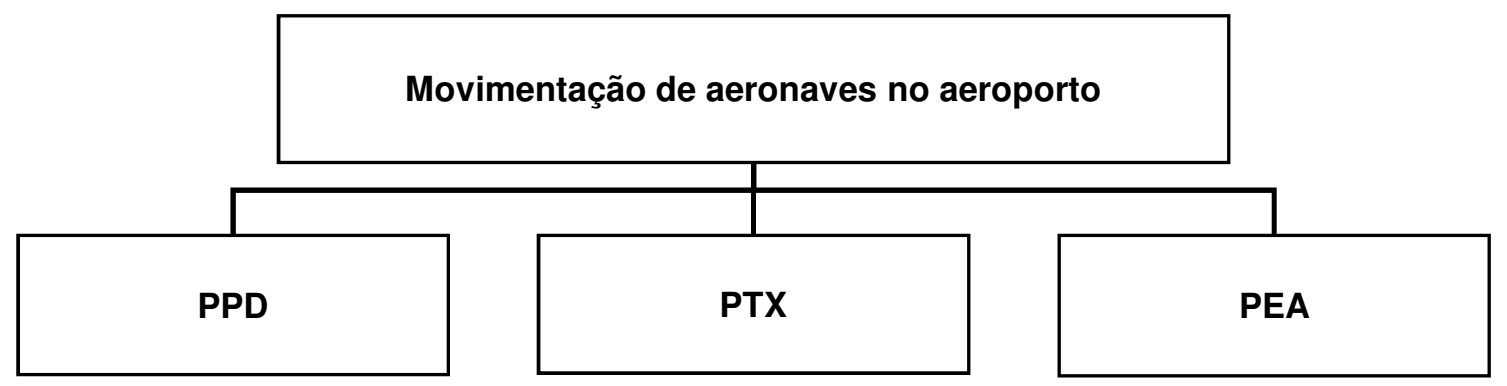

Fonte: Elaboração Própria

Embora nem toda PPD de um aeroporto seja pavimentada, como no caso de pistas de aeroportos privados para operações de pequenas aeronaves privadas ou desportivas, nos aeroportos comerciais considerados para a modelagem desenvolvida, para operação de aeronaves de médio e grande porte, obrigatoriamente as superfícies que recebem essas aeronaves devem ser pavimentadas e estruturalmente suportar tais equipamentos.

Porém, antes da revisão que trata especificamente das superfícies tratadas como escopo desse trabalho, é interessante uma contextualização sobre a pavimentação a ser aplicada nos elementos do aeroporto em questão; por isso, nas seções imediatas são apresentadas características gerais sobre pavimentos aeroportuários, bem como faz-se a apresentação dos tipos de pavimentação empregados nas superfícies pavimentadas dos aeroportos destinadas ao trânsito de aeronaves.

\subsubsection{Pavimentos aeroportuários}

Um dos fatores mais importantes, para realização de uma viagem aérea com segurança e conforto, é o pavimento no qual a aeronave opera (DURAN, 2015).

Os pavimentos aeroportuários são projetados, construídos e mantidos de modo a suportar as cargas críticas que são aplicadas, além de fornecer regularidade, resistência à derrapagem e uma superfície segura e confortável, tanto para as aeronaves como para os passageiros. Deve ainda prover qualidade e espessuras das camadas que compõem sua estrutura suficientes para garantir que a estrutura não 
falhará pela ação das cargas aplicadas, efeito abrasivo do tráfego, condições climáticas adversas e outros fatores de deterioração (FAA, 2016).

Segundo FAA (2016) o pavimento aeroportuário aplicado nas pistas de aeroportos é uma estrutura de engenharia complexa, que considera quatro principais elementos para seu dimensionamento: o subleito do local (solo original), os materiais de construção para as camadas, as características das cargas aplicadas e o clima.

O pavimento típico aeroportuário apresenta a seguinte estrutura básica apresentada na Figura 17.

Figura 17 - Estrutura de um pavimento aeroportuário típico
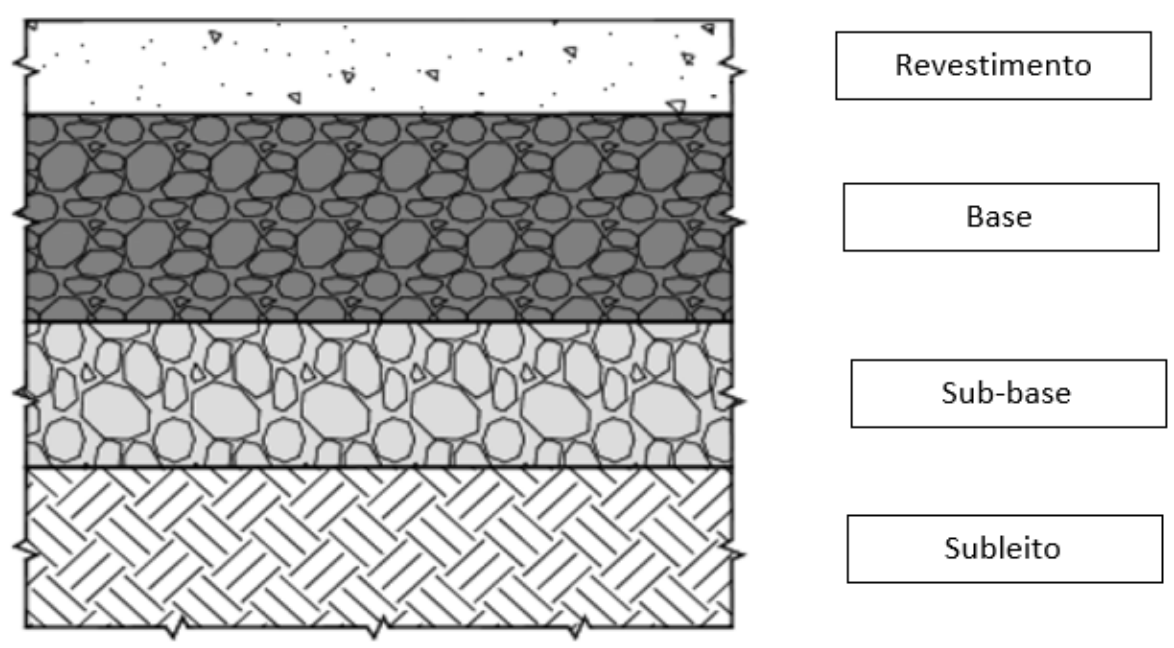

Fonte: FAA (2016) - Adaptado

Destaca-se que esse normativo, além de muito empregado mundialmente, é também muito usado em projetos do gênero também no Brasil. Para esse estudo, a modelagem física seguirá seus preceitos.

Os pavimentos aeroportuários podem ser divididos em dois tipos básicos: flexíveis e rígidos (verificados na maioria dos aeroportos). Atualmente já existem outras tecnologias e tipos de pavimentação, no entanto, como não são encontrados nos projetos convencionais de aeroportos, delimitou-se, para esse estudo apenas os flexíveis e rígidos. Na sequência, características gerais sobre esses tipos de pavimentação são apresentadas. 


\subsubsection{Pavimentação flexível}

Pavimentos flexíveis são compostos por um revestimento asfáltico apoiado sobre um conjunto de camadas subsequentes, que são constituídas com materiais selecionados, como solos, misturas de solos e materiais granulares (DURAN, 2015).

As camadas que compõem um pavimento flexível são brevemente descritas na sequência, segundo Balbo (2007):

- Revestimento ou camada superficial: composta por uma mistura betuminosa constituída por agregados selecionados unidos por ligantes betuminosos. A camada de revestimento tem as funções principais de criar uma superfície uniforme, estável, durável, aderente, evitar a entrada de água para as camadas inferiores e resistir ao cisalhamento induzido pelos carregamentos;

- Base: pode ser constituída por solo estabilizado naturalmente, misturas de solos e agregados, brita graduada, brita graduada com cimento, solo com ligantes hidráulicos ou asfálticos. Representa a componente estrutural principal do pavimento, pois tem a função de resistir e distribuir os esforços às camadas inferiores, resistindo ao cisalhamento, evitando a consolidação e deformação do pavimento. Também pode desempenhar um importante papel na drenagem subsuperficial dos pavimentos;

- Sub-base: semelhante à base, pode ser usada por razões de natureza construtiva ou econômica. Geralmente empregadas em locais para onde se necessita ação corretiva do subleito, ou complementar à base, evitando espessas excessivas da base por serem aquelas em geral de maior custo;

- Subleito: solo natural consolidado e compactado, que conforma a fundação da estrutura. Superfície obtida pela terraplenagem ou obra de arte e conformada ao greide e seção transversal, constituído de material natural, consolidado e compactado.

Com isso, a Figura 18 apresenta a configuração básica de um pavimento "flexível", que pode ser definido como aquele constituído por camadas que não trabalham à tração. 
Constituídos com revestimento betuminoso delgado sobre camadas puramente granulares, a estrutura do pavimento tem sua capacidade de suporte em função das características de distribuição de cargas por um sistema de camadas superpostas, onde as de melhor qualidade encontram-se mais próximas da carga aplicada, segundo Inouye (2009 apud MARQUES, 2002).

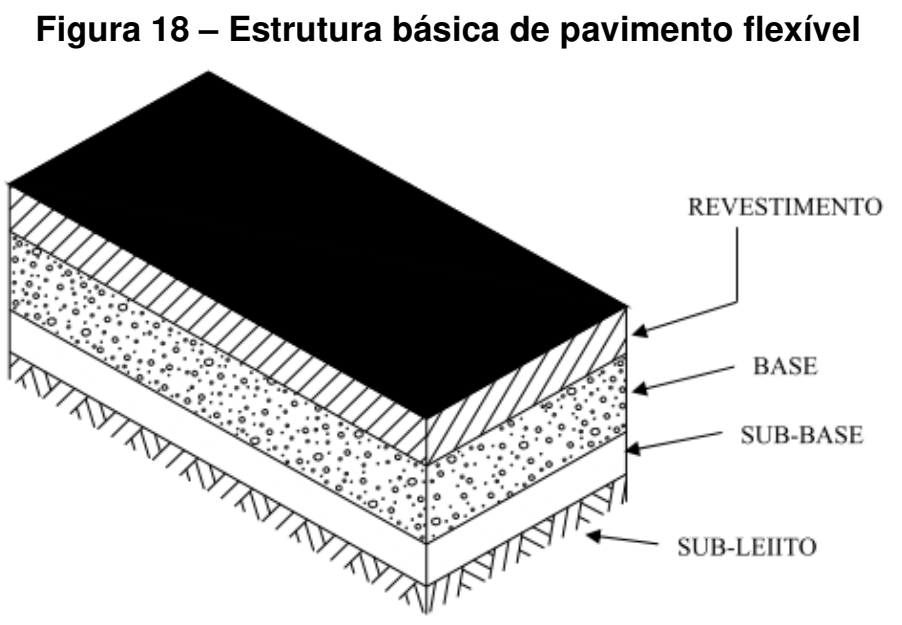

Fonte: FONSECA (1990)

\subsubsection{Pavimentação rígida}

Pavimentos rígidos apresentam a camada de revestimento composta por placas de concreto de cimento Portland. Essa camada atua como suporte estrutural e como elemento impermeabilizante. Podem ser armados ou protendidos com a finalidade de controlar e minimizar os efeitos danosos das trincas e promover uma transferência adequada dos carregamentos entre as placas (FONSECA,1990).

As camadas que compõem um pavimento rígido são brevemente descritas na sequência, segundo FAA (2016):

- Revestimento - Placas de concreto de cimento Portland: fornecem suficiente suporte estrutural ao trânsito de aeronaves, além de uma superfície resistente à derrapagem e infiltrações de água nas camadas inferiores;

- Base: camada que oferece suporte uniforme para assentamento das placas de concreto; 
- Sub-base: o principal benefício estrutural é refletido no módulo de reação do solo do subleito e conferido para a fundação. Essa camada é recomendada em pavimentos destinados para movimentação de aeronaves com peso igual ou superior a $45.000 \mathrm{~kg}$;

- Subleito: solo natural consolidado e compactado, que conforma a fundação da estrutura. Superfície obtida pelo terraplenagem ou obra de arte e conformada ao greide e seção transversal, constituída de material natural, consolidado e compactado.

A Figura 19 apresenta a configuração básica de um pavimento "rígido", que é constituído por camadas que trabalham essencialmente à tração. Seu dimensionamento é baseado nas propriedades resistentes de placas de concreto de cimento Portland, aplicadas sobre camadas de transição (INOUYE 2009 apud MARQUES, 2002).

Figura 19 - Estrutura básica de pavimento rígido

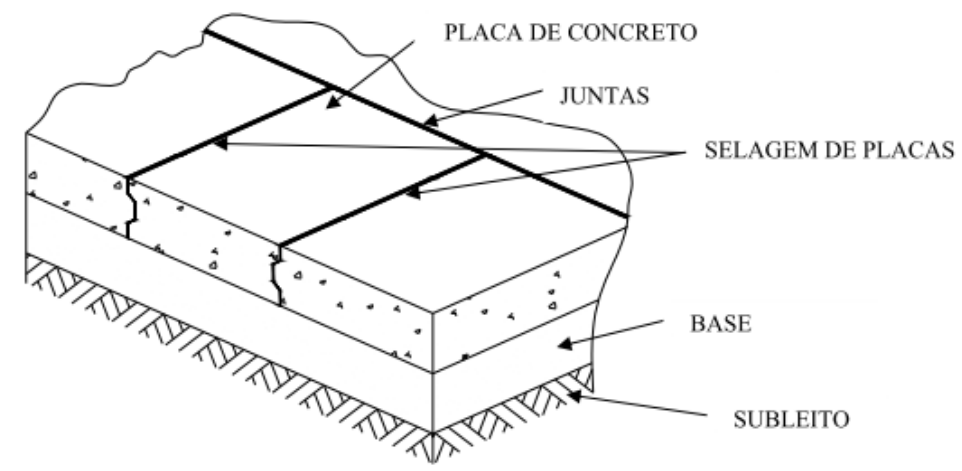

Fonte: FONSECA (1990)

Considerando que as pistas podem ser pavimentadas com materiais flexíveis ou rígidos, Young e Wells (2014) indicam que uma pavimentação rígida feita com concreto pode permanecer útil entre 20 e 40 anos; apresentam maiores custos de construção e menores interferências para manutenção. Para a realidade do parque de aeroportos brasileiros, esse fato justifica seu emprego nos pátios de estacionamentos de aeronaves nos principais aeroportos comerciais.

Já as pistas que recebem pavimentação flexível costumam alcançar vida útil entre 15 e 20 anos, considerando projeto, construção e manutenção apropriados. Apresentam 
também menores custos de construção, além de técnicas construtivas mais simplificadas em relação à pavimentação rígida (YOUNG; WELLS, 2014). Para o caso dos aeroportos brasileiros, quase que a totalidade das pistas de pouso e decolagem e pistas de táxi recebem esse tipo de pavimentação.

Finalizando essa seção, para compreensão do comportamento dos dois tipos de pavimentação tratados, a Figura 20 apresenta, segundo a Associação Brasileira Cimento Portland (ABCP), a forma de distribuição das cargas entre pavimentos equivalentes.

Figura 20 - Comparação da forma de distribuição de carga em pavimentos equivalentes

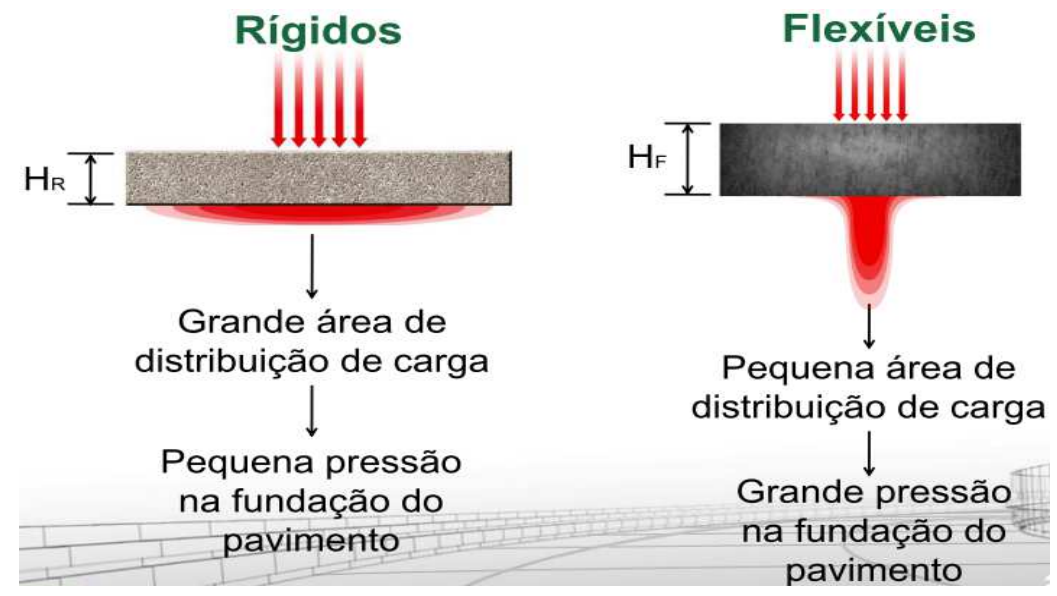

Fonte: ABCP - Adaptado ${ }^{4}$

Ainda no bojo da discussão do emprego de pavimentação rígida frente à flexível para os Pátios de estacionamento de aeronaves, a Figura 21 exemplifica o efeito que pode ocorrer no caso de estacionamentos prolongados de aeronaves em pavimentos flexíveis. É ilustrado um afundamento de aproximadamente $5 \mathrm{~cm}$, justamente na área onde ficam as rodas do trem de pouso principal das aeronaves.

\footnotetext{
${ }^{4}$ Disponível em:

http://www.dtt.ufpr.br/Pavimentacao/Notas/Pavim_Concreto_Apres_Mod02\%20ABCP.pdf. Acesso em 02/01/2019.
} 
Figura 21 - Afundamento do pavimento asfáltico em um Pátio de estacionamento de aeronaves

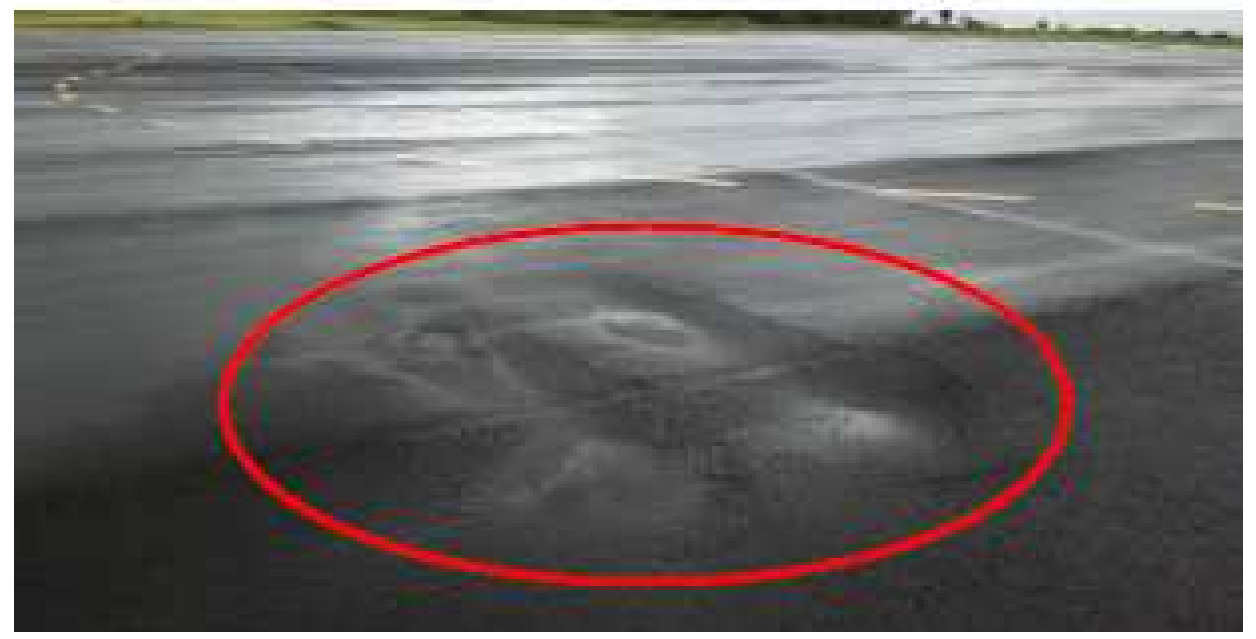

Fonte: DURAN (2015) - Adaptado

Com isso, verifica-se que, mesmo que com custo maior de construção em relação à pavimentação flexível; devido às deformações acarretadas pela incidência por longos períodos das cargas oriundas dos trens de pouso das aeronaves, opta-se muitas vezes pela aplicação de pavimentos rígidos compostos por revestimento com placas de concreto de cimento Portland nesses pátios.

Para as superfícies de rolamento, cujas as cargas são transitórias - Pista de pouso e decolagem e Pistas de táxi, acaba-se muitas vezes recorrendo-se à pavimentação flexível, com menores custos de construção e manutenibilidade incidentes.

Complementando a compreensão, mesmo que superficial, sobre pavimentação: o revestimento, ou seja, a camada final exposta ao rolamento, pode ser flexível (asfáltica) ou rígida (composta de placas rígidas de concreto). Essas placas rígidas são conectadas por juntas que permitem movimentações em virtude das contrações ou expansões, como resultado da aplicação das cargas das aeronaves quando sobre as superfícies e resultantes das mudanças de temperatura (INOUYE, 2009).

\subsubsection{Dimensionamento de pavimentos aeroportuários}

Para dimensionamento adequado de uma estrutura de pavimento, é necessário o conhecimento das propriedades dos materiais que compõem a mesma, para que 
resistam à ruptura, permeabilidade e deformabilidade, frente às repetições de carga e efeitos do clima (BERNUCCl et al., 2008).

A escolha do tipo de pavimento a ser empregado nos aeroportos (destinados ao trânsito de aeronaves) envolve fatores técnicos e econômicos. Como já comentado, verifica-se uma tendência em usar pavimentação flexível nas áreas destinadas ao pouso, decolagem e rolamento das aeronaves (PPD e PTX), e pavimentação rígida nas destinadas ao estacionamento de aeronaves (PEA), devido a uma maior resistência desse tipo de pavimento às cargas estáticas e à ação química de combustíveis, óleos e lubrificantes (DURAN, 2015).

Para o dimensionamento de pavimentos aeroportuários, existem alguns métodos referenciados na literatura, sejam eles propostos pelos fabricantes de aeronaves, normas técnicas ou por autoridades de aviação civil de diversos países.

Dentre os métodos verificados, nesse trabalho optou-se por empregar um software desenvolvido especialmente para essa finalidade, no qual alguns parâmetros são inseridos e o software dimensiona, de forma otimizada (técnica e economicamente), as camadas do pavimento aeroportuário.

Esse software é o FAIRFIELD v1.42, desenvolvido pela Federal Aviation Administration (FAA), agência reguladora da aviação civil dos Estados Unidos da América. Adiante, na seção sobre dimensionamento da pavimentação, maior detalhamento sobre o software e seu uso serão apresentados.

Como histórico, para pavimentos de aeroportos, o envolvimento americano na Segunda Guerra Mundial, levou os engenheiros militares daquele país a formalizar metodologia específica para dimensionamento (empregada até hoje), frente a suas necessidades para desenvolvimento de aeródromos. Tal fato tornou os Estados Unidos da América um dos países que mais desenvolvimentos na área de pavimentação realizaram no século passado.

Métodos empíricos foram tomados como base, entre eles, o California Bearing Ratio (CBR). Essa metodologia mais tarde foi absorvida e normalizada, tanto nos EUA, como por outras agências em outros países (BALBO, 2007). 
No caso de dimensionamento de pavimentos rígidos, emprega-se o coeficiente de recalque $(k)$, que pode ser obtido através de correlação com o CBR.

Segundo (BRASIL, 2004), quanto menor o valor do CBR, menor capacidade de suporte tem esse solo. Neste trabalho não são expostos maiores detalhamentos sobre projeto de pavimentos aeroportuários, uma vez que o mesmo é alicerçado na cadeira de gestão e produtividade da construção civil. Estudos e desenvolvimentos detalhados são amplamente encontrados em pesquisas de referências na área da pavimentação. 


\section{MODELAGEM PARAMÉTRICA}

Para Gonçalves (2011), parametrizar é correlacionar, por aproximação, serviços e preços dos principais itens da construção, com as poucas informações disponíveis.

Apesar de a maioria das estimativas de custo levar em conta apenas a área construída do empreendimento, muitas outras variáveis interferem diretamente no custo (KATO, 2013).

A fragmentação do custo total em parcelas menores, com a utilização de direcionadores de custo específicos para cada uma de suas partes, possibilita uma redução do erro intrínseco ao método de estimativa. Desta maneira, pode-se compor um grupo de relações paramétricas de custo que, utilizadas em conjunto, estabelecem prognósticos completos de custo, sendo tal estrutura denominada modelo paramétrico de custo (OTERO, 2000).

A estimativa paramétrica é uma técnica usada por contratantes a fim de acelerar o processo, no caso em que outra técnica exija maior tempo e recursos, sendo que os resultados entre elas seriam semelhantes (UNITED STATES OF AMERICA, 1995).

Trata-se de um orçamento aproximado que se adequa às análises preliminares de viabilidade. Para sua elaboração, uma vez que os projetos podem ainda não estar disponíveis, são utilizados índices de consumo baseados em obras anteriores ou indicadores da construção civil (SANTOS, 2015).

É na fase inicial que se justifica a utilização de modelos paramétricos de custos, pois não se busca um custo determinístico preciso e sim um custo aproximado (LOSSO, 1995).

Técnicas de paramétricas enfocam partes principais que caracterizam o produto sob estudo e mantêm maior influência sobre seu custo, não se preocupando com detalhes presentes no processo.

Os direcionadores de custo são características controláveis do produto, estabelecidas em plantas, especificações e cronogramas, e que possuem efeito predominante sobre o sistema de custo. Deste modo, utilizam-se alguns poucos parâmetros importantes, 
conformados a partir dos direcionadores de custo, que possuem o impacto mais significativo sobre o produto em estudo (UNITED STATES OF AMERICA, 1995).

O longo período de maturação da obra, a vulnerabilidade da indústria da construção civil às alterações de ordem político-econômica do país e a variabilidade inerente ao processo produtivo nesta indústria são alguns fatores que fazem com que a precisão de estimativas preliminares seja afetada (HIROTA, 1987).

De acordo com Graça e Gonçalves (1978), existe um número ótimo de atividades a serem analisadas, definidas em função do tipo de estimativa. Na Figura 22, é apresentada uma curva evidenciando que, a partir de determinado ponto, o incremento na precisão é muito pequeno em relação ao número de informações.

\section{Figura 22 - Número de informações versus precisão na estimativa de custos de projetos de} construção civil

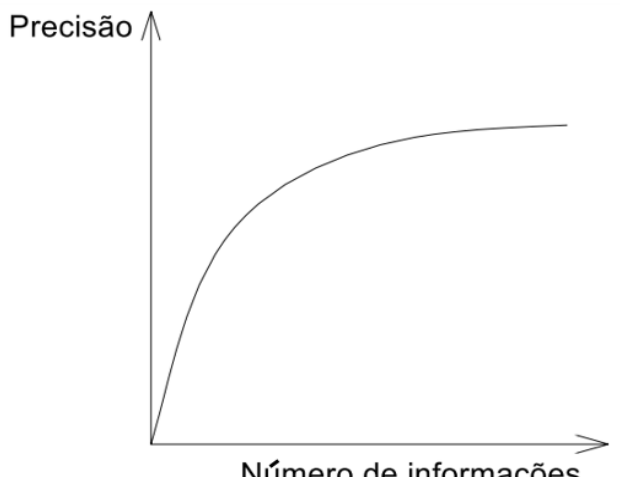

Fonte: GRAÇA; GONÇALVES (1978) - Adaptado

Justamente nesse ponto, o valor do trabalho desenvolvido é verificado. Com reduzidas informações preliminares, é aplicada a modelagem paramétrica e se obtém um custo bastante adequado à fase de análises preliminares.

Segundo Kato (2013), no Brasil a modelagem paramétrica é bastante difundida, conforme pesquisa na bibliografia existente sobre o assunto. No entanto, para uso em projetos de aeroportos, referências sobre esse fato não foram encontradas.

É do interesse de qualquer empresa, seja pública ou privada, conhecer com um certo tempo de antecipação quais serão os seus custos. Tal informação mostra-se útil para a análise da viabilidade de projetos futuros, realização de novos contratos, ajustes de preços, entre outros. Nesse contexto, o conceito de modelo paramétrico de custos 
apresenta-se como uma solução factível para a estimação destes (BARROS; OLIVEIRA; FERREIRA, 2016).

Atualmente as técnicas que empregam modelos paramétricos são usadas em diversas atividades, tais como:

- Estudos de tendência;

- Gerenciamento de atividades em projetos;

- Custos de projetos;

- Análises de competitividade, entre outras.

Nessa seara, a modelagem paramétrica, aplicada à estimativa de custos em empreendimentos que envolvem construção civil, apresenta-se como um método que não exige elevada especialização e fornece formatos de cálculos e resultados adequados para o propósito. O autor considera, por tudo que foi mostrado neste texto, que este modelo é o mais adequado, dentre aqueles anteriormente mostrados, para se fazer a estimativa de custos com precisão adequada, num cenário de disponibilidade inicial de dados sobre o objeto sendo precificado.

Considera-se ainda que a indústria da construção é um setor extremamente competitivo, aliada a necessidade de as empresas necessitarem de previsões rápidas e com precisão adequada dos custos, uma vantagem vital nos estudos de viabilidade (UGUR et al., 2019).

\subsection{ESTUDOS SOBRE ESTIMATIVAS PARAMÉTRICAS DE CUSTOS NA CONSTRUÇÃO CIVIL}

Há um constante aprofundamento das abordagens sobre o emprego de estimativas paramétricas de custos na construção civil. Parisotto (2003), o qual apresenta uma síntese cronológica sobre esse emprego. 
No início da década de 80 do século XX, pesquisadores desenvolvem e publicam trabalhos que apresentam parâmetros para avaliação do custo do projeto para a fase de investimentos.

Em meados daquela década, o pesquisador Juan Luis Mascaró apresenta conceitos que podem ser considerados como a base filosófica de todos os trabalhos que se desenvolveram sobre esse tipo de estimativa nesta área. Dentre os conceitos, apresentou dados sobre como as decisões arquitetônicas influenciam nos custos de um empreendimento.

A partir da base conceitual formada, Hirota (1987) inicia uma pesquisa que objetivava identificar a influência dos projetos-padrão como base para o levantamento de dados sobre indicadores de consumo de insumos e custos de produção.

Losso (1995) apresenta a disseminação das metodologias de prognósticos de custos e a obtenção de índices médios para análise da quantificação e do custo de empreendimentos na fase de anteprojeto. A proposta para análise do custo baseavase na quantificação dos serviços, uma vez que, segundo o autor, esses possuem uma correlação direta entre si.

Em seguida foram desenvolvidas pesquisas cujo objetivo era a determinação do custo do empreendimento. Otero (2000), analisou a precisão do uso dos modelos paramétricos em estimativas de custos e quantidades de serviços, materiais e mão de obra aplicada na construção civil.

Desde então outros pesquisadores vêm aplicando a modelagem paramétrica, com o desenvolvimento de aplicações específicas, ligadas quase sempre ao setor de edificações.

Por fim, empregando-se o estado da arte sobre o modelamento paramétrico, Gan et al. (2019) aplicam relacionamento de funções com diversas variáveis em modelamentos paramétricos desenvolvidos para aplicações específicas, desde definição de sistemas estruturais de edificações até a estimação dos custos construtivos. Segundo esses autores as constantes evoluções na modelagem paramétrica permitem a otimização na busca de resultados. 


\subsection{APLICAÇÕES DE RELAÇÕES PARAMÉTRICAS PARA ESTIMAR CUSTOS}

A utilização de relações paramétricas em estimativas de custo apresenta uma série de etapas que devem ser consideradas de modo a se obterem os resultados com maior confiabilidade.

Quanto melhor o modelo paramétrico estabelecido, mais próximo estará o custo estimado daquele realmente incorrido ao final do projeto.

Segundo o Parametric Cost Estimating Handbook (UNITED STATES OF AMERICA, 1995), as etapas podem ser resumidas em:

- Levantamento de dados;

- Avaliação e tratamento de dados;

- Reconhecimento de direcionadores de custo;

- Análise destes direcionadores;

- Estabelecimento de relações paramétricas;

- Seleção de relações válidas e validação do modelo paramétrico.

As atividades de coleta e sistematização de dados, para a produção de uma estimativa, e a avaliação destes dados com relação a sua funcionalidade são passos críticos dentro do processo, consumindo maior tempo. A correção e confiabilidade da base de dados utilizada são fatores determinantes para a qualidade.

Na montagem dos bancos de dados devem ser identificados produtos similares àquele sobre o qual será realizado o estudo, anotando informações referentes aos custos relacionados à produção destes e a suas principais características descritivas, especialmente aquelas que mantêm maior influência sobre tais custos (UNITED STATES OF AMERICA, 1995). 
Um dos requisitos fundamentais para a inclusão de uma variável, numérica ou não, como direcionador de custo em relações paramétricas, é que esta seja um fator estatisticamente significativo sobre o custo do produto ou parte deste.

Neste sentido, as ferramentas estatísticas mais utilizadas são testes de hipótese sobre regressões lineares ou linearizadas, regressões múltiplas e análise de variância.

Ao se trabalhar com modelos paramétricos fundamentados em composições e preços unitários similares para os mesmos serviços, a incerteza presente na estimativa do valor médio esperado para o custo total reflete exatamente as diferenças existentes em termos de características geométricas, soluções construtivas e ainda às incertezas ligadas à produtividade de mão de obra, consumo de materiais e preço de insumos (OTERO, 2000).

\subsection{CONCEITOS SOBRE MODELAGEM PARAMÉTRICA}

Estimativa paramétrica pode ser definida como uma técnica de estimação de custos baseada nas relações existentes entre as características técnicas e programáticas de um projeto com os respectivos custos e recursos utilizados em seu desenvolvimento.

Baseia-se em equações matemáticas para relacionar a variável de custo ou desempenho (variável dependente) com as demais variáveis (independentes). $\mathrm{O}$ processo se utiliza das informações históricas dessas variáveis na construção de um modelo paramétrico de custo (ECK et al., 2009).

Baseando-se no NASA Cost Estimating Handbook Version 4.0 (UNITED STATES OF AMERICA, 2015), empregado em programas daquela agência, o processo para estimativa de custo de um projeto segue basicamente as três macro etapas: definição das tarefas de projeto, metodologia para estimar custos das tarefas e resultado com os custos das tarefas.

Considerando o escopo do trabalho, dentro da segunda etapa, destaca-se a atividade de seleção da metodologia. Complementando de forma lógica a argumentação, a 
Figura 23 situa a pertinência do uso do modelo paramétrico para estimar custos em fases preliminares.

O modelo paramétrico permite, nas fases iniciais (concepção e projeto) e até mesmo no início da construção, entregar bons resultados em termos de acurácia, no que refere-se aos custos.

Figura 23 - Situação do modelo paramétrico como método para estimativa de custos de projetos

\begin{tabular}{|c|c|c|c|}
\hline Concepção & Projeto & Construção & $\begin{array}{c}\text { Operação e } \\
\text { Manutenção }\end{array}$ \\
\hline & & & Extrapolações \\
& Parametria & & $\begin{array}{c}\text { Engenharia de } \\
\text { custos }\end{array}$ \\
\hline Analogia & & & \\
\hline Estimativas simplificadas & \multicolumn{2}{|c|}{ Estimativas detalhadas } \\
\hline
\end{tabular}

Fonte: UNITED STATES OF AMERICA (2015) - Adaptado

A técnica paramétrica também é considerada como expedita, trabalhando com um número reduzido de informações na caracterização de um projeto, tendo seu processamento baseado em poucas equações matemáticas, obtendo-se resultados rapidamente.

As estimativas de custo da National Aeronautics and Space Administration (NASA) são frequentemente requisitadas quando estão em desenvolvimento sistemas espaciais ou softwares específicos para missões. Para esses projetos agilidade é necessária; no entanto, como são de natureza complexa, simples correlações sem as devidas parametrizações não seriam adequadas, segundo United States of America (2015).

O modelo paramétrico de custo é um método que utiliza relações sob a forma de algoritmos matemáticos ou lógicos, de modo a obter uma estimativa de custos. Tais relações, denominadas relações paramétricas de custo, podem variar desde simples regras informais ou analogias básicas, até funções matemáticas complexas decorrentes da análise estatística de dados (OTERO, 2000). 
Geralmente, a fragmentação do custo total em parcelas menores, com a utilização de direcionadores de custo específicos para cada uma de suas partes, possibilita uma redução do erro intrínseco ao método (UNITED STATES OF AMERICA, 1995).

Segundo Kato (2013), um modelo paramétrico para estimar de custos de produção é aquele que emprega modelos matemáticos com base em informações históricas.

Com isso, um modelo adequado e muito útil foi apresentado por Kim; An; Kang (2004), expresso pela Equação 1:

$$
Y=C+b_{1} \cdot X_{1}+b_{2} \cdot X_{2}+b_{n} \cdot X_{n}
$$

Onde: Y é o resultado do custo total de construção; $C$ é a constante estimada; $b_{1}, b_{2}$, $b_{n}$ são os coeficientes estimados pela análise de regressão; $X_{1}, X_{2}, X_{n}$ são as variáveis com as características do produto.

Outras considerações importantes também valem ser indicadas no que se refere a modelos paramétricos. Uma vez que custo aferido e precisão podem variar muito em etapas preliminares de um projeto, um modelo é mais útil e realista quando:

- As informações inseridas, que alimentam a modelagem, forem o máximo precisas no momento;

- Os parâmetros empregados nos estudos forem quantificáveis; e

- O modelo permitir o escalonamento no uso, ou seja, comportar-se bem para modelagens de projetos extensos e também em projetos diminutos.

Por fim, as maiores vantagens que se pode atribuir a modelos paramétricos são: rapidez e facilidade de replicação (UNITED STATES OF AMERICA, 2015).

Para Dysert (2008) os modelos paramétricos possuem algumas vantagens em relação aos demais, tais como:

- Eficiência, pois exige um grau menor de detalhamento do banco de dados e pode ser calculado em estágios iniciais do projeto, sendo gradativamente atualizado conforme a evolução do projeto; 
- Objetividade, pois tem como entradas os dados quantitativos que serão utilizados em algoritmos, que gerarão, por sua vez, saídas também quantitativas. Assim, os custos são facilmente rastreáveis;

- Consistência, caso sejam inseridos dois valores iguais de inputs, seus outputs serão iguais; e

- Flexibilidade, pois os modelos paramétricos aceitam uma gama de valores de entrada e extrapolam em uma gama de diferentes análises.

Dessa forma, verifica-se que modelos paramétricos são possíveis soluções para análise prévia de custos.

\subsection{DIFICULDADES NO USO DA MODELAGEM PARAMÉTRICA}

Uma das dificuldades na utilização prática de modelos paramétricos encontra-se na atualização dos custos estabelecidos dentro destes para uma data diferente daquela em que se baseia a amostra, sendo que o uso de índices inflacionários gerais pode não se mostrar adequado a este processo.

Neste sentido, o estudo de pacotes de insumos referentes aos diversos grupos de serviços pode ser uma opção para a definição de seus custos. Com a definição dos preços atualizados destes insumos, os custos destes pacotes podem ser corrigidos e utilizados na determinação de índices específicos para adequação a uma nova data.

Em princípio, há limitações para o uso de modelos paramétricos quanto à definição muito restrita de tipologia e localização das obras para a amostra sob estudo, sendo que estudos posteriores devem estabelecer a possibilidade de se ampliar o universo abrangido por um mesmo modelo. Para a utilização de relações paramétricas para estimativas envolvendo obras fora do universo tipológico estabelecido, deve ser realizado um estudo de compatibilidade entre seus dados (OTERO, 2000). 


\subsection{CONCEITOS DE ESTATÍSTICA ENVOLVIDOS NO USO DE MODELOS PARAMÉTRICOS}

O conhecimento do comportamento das variáveis estudadas sob o ponto de vista estatístico é importante na medida em que alimenta a modelagem das equações de custos, analisa a dispersão dos valores com relação aos parâmetros estatísticos aceitáveis e também determina a equação de regressão para cada equação paramétrica de custos.

Quando se trabalha com equações de regressão linear entre duas variáveis, sendo uma variável dependente e outra variável independente, devem-se medir as discrepâncias existentes entre os valores reais e estimados, de maneira a definir o erro padrão (HIROTA, 1987).

Neste caso utiliza-se o parâmetro de análise do coeficiente de determinação $\left(R^{2}\right)$, que representa a capacidade de uma das variáveis explicar a variação da outra.

Como exemplo, a Figura 24 apresenta análise desse parâmetro em estudo dentro de um processo de estimativa paramétrica da National Aeronautics and Space Administration (NASA). Nele relaciona-se o peso de determinada quantidade de suprimentos a ser levada em missão aeroespacial frente ao custo para transporte desse peso, seguindo regressão linear.

Figura 24 - Exemplo de regressão linear para análise de variáveis

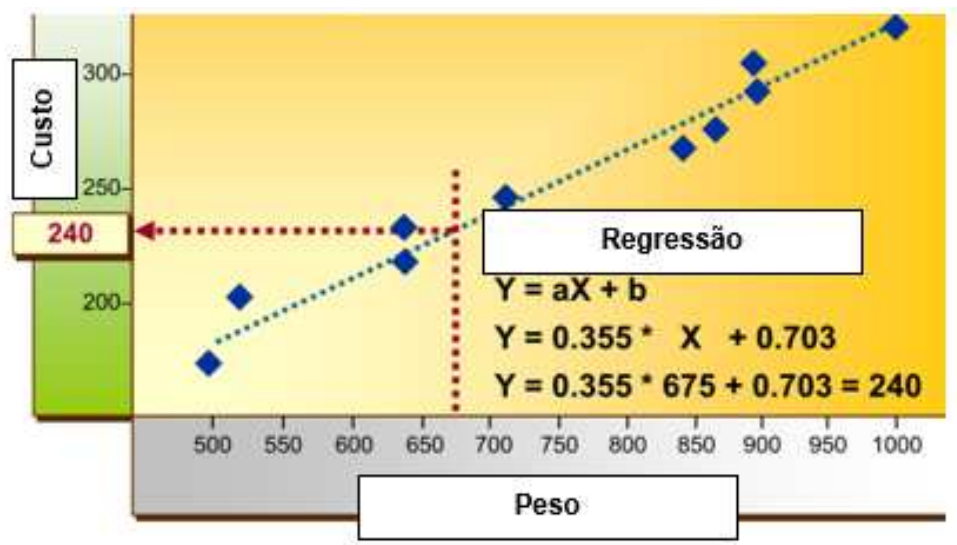

Fonte: UNITED STATES OF AMERICA (2015) - Adaptado 
No exemplo apresentado na Figura 24, para um peso de equipamentos de 675 unidades de peso, o custo seria de 240 unidade monetárias.

Seguindo a ampla literatura das ciências estatísticas, para analisar parâmetros e verificar se as correlações são aceitáveis, tem-se: quanto mais próximo de 0 (zero) é o valor de $\mathrm{R}^{2}$, mais fraca a correlação. No lado oposto, quanto mais próximo de 1 (um) é o valor de $\mathrm{R}^{2}$, mais forte é a correlação.

Com isso, estimativa de custo paramétrica pode ser definida como o resultado lógico e matemático da relação entre as características físicas e funcionais de um projeto com o seu custo final. Considera-se como variável dependente o preço de um certo produto, serviço ou contrato enquanto as demais variáveis que explicam os custos são ditas variáveis independentes (BARROS; OLIVEIRA; FERREIRA, 2016). 


\section{CARACTERIZAÇÃO DOS COMPONENTES DO SISTEMA AEROPORTUÁRIO BRASILEIRO}

O modelo desenvolvido e proposto neste trabalho seguiu os conceitos preconizados para estudos paramétricos. Apenas com informações preliminares, que são as únicas geralmente conhecidas pelo empreendedor ou planejador nas etapas iniciais de análise de viabilidade, um conjunto de parâmetros é delimitado e aplicado num modelo paramétrico para estimativa dos custos de construção dos elementos escopo desse trabalho.

Como a modelagem destina-se ao estudo para construção de aeroportos domésticos brasileiros (que realizam operações exclusivamente de e para destinos nacionais), para embasar as relações paramétricas que influenciam os custos de construção das superfícies pavimentadas para operações de aeronaves, conhecer características dos aeroportos, frotas das companhias aéreas que operam no mercado de transporte aéreo brasileiro e, por conseguinte, as principais aeronaves operadas nos aeroportos, permite verificar relações e correlações.

Essas caracterizações surgem, ainda, como uma possibilidade de incrementar e gerar um modelo para estimar os custos de construção das superfícies pavimentadas para operações de aeronaves mais fidedigno à realidade desse setor da construção civil brasileira.

\subsection{CARACTERIZAÇÃO DOS AEROPORTOS BRASILEIROS}

Para desenvolvimento da modelagem proposta, o conhecimento de características peculiares dos aeroportos brasileiros de diversos portes foi necessário. Para isso, considerando o acesso a informações confiáveis, a diversidade dos aeroportos operados e conhecimentos prévios do autor sobre a realidade do parque de aeroportos brasileiros, elegeram-se 27 aeroportos, distribuídos em todas as regiões do país, operados pela INFRAERO (Empresa Brasileira de Infraestrutura Aeroportuária), para serem caracterizados e embasarem os estudos realizados. 
Como breve contextualização, a INFRAERO é uma empresa pública brasileira que tem por finalidade implantar, administrar e operar equipamentos de infraestrutura aeroportuária e de apoio à navegação aérea, além de prestar consultoria em suas áreas de atuação e na construção de aeroportos (INFRAERO, 2018a). Opera 54 aeroportos em todo o território nacional ${ }^{5}$.

No entanto, devido ao grande número de aeroportos e à grande diversidade de espécies de operações aéreas em cada um deles, foram selecionados 27 dos 54 aeroportos em questão (listados no Quadro 3). Essa seleção seguiu os seguintes critérios:

- Aeroportos mais representativos do território nas diferentes regiões;

- Demanda atendida superior a 300.000 passageiros/ano, com base nas informações de INFRAERO (2018b);

- Aeroportos com operações regulares de aviação comercial regular (servidos pelas companhias aéreas de transporte público), visto que parte dos aeroportos operam apenas aviação geral (instrução, executiva e privada).

O Apêndice A registra a caracterização completa, com as informações pertinentes a esse trabalho, de cada um dos 27 aeroportos selecionados. São apresentadas as principais características físicas de cada aeroporto, figuras ilustrando a implantação do sítio aeroportuário, além das cartas aeronáuticas de cada aeródromo, nas quais verificam-se as dimensões dos mesmos.

A título de informação, as cartas aeronáuticas não são documentos de utilidade primária para projetos de engenharia civil. São utilizadas, pelos pilotos das aeronaves e setor de engenharia de operações das companhias aéreas, em estudos para elaboração de rotas, preparação de documentação para voos (na qual verificam-se as condições dos aeródromos de partida, chegada e alternativos, frente à capacidade, desempenho e situação das aeronaves engajadas).

${ }^{5}$ De acordo com INFRAERO (2018b). 
No Quadro 3 são sintetizadas as informações pertinentes a este trabalho de cada aeroporto caracterizado.

Quadro 3 - Aeroportos caracterizados

\begin{tabular}{|c|c|c|c|c|c|c|c|c|}
\hline \# & $\begin{array}{l}\text { 운 } \\
\frac{0}{0} \\
\frac{0}{0}\end{array}$ & $\begin{array}{l}\frac{0}{0} \\
\frac{\pi}{0} \\
\frac{0}{0}\end{array}$ & $\begin{array}{l}\text { 음 } \\
\frac{\text { d }}{0} \\
\text { w }\end{array}$ & 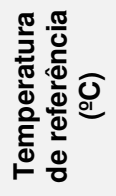 & 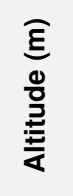 & 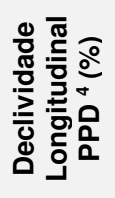 & 峁 & 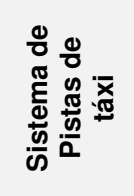 \\
\hline 1 & Santa Maria & Aracaju & SE & 31 & 7 & 0,04 & 18.000 & simples \\
\hline 2 & Internacional Val-de-Cans & Belém & PA & 32 & 15 & 0,15 & 50.000 & simples \\
\hline 3 & Internacional de Campo Grande & Campo Grande & MS & 36 & 557 & 0,21 & 25.000 & complexo \\
\hline 4 & Internacional Afonso Pena & Curitiba & PR & 25 & 908 & 0,21 & 90.000 & complexo \\
\hline 5 & Internacional Mal. Rondon & Cuiabá & MT & 35 & 184 & 0,37 & 50.000 & complexo \\
\hline 6 & Internacional Eduardo Gomes & Manaus & AM & 34 & 78 & 0,12 & 80.000 & complexo \\
\hline 7 & Internacional Cataratas & Foz do Iguaçu & PR & 32 & 236 & 0,36 & 35.000 & simples \\
\hline 8 & Santa Genoveva & Goiânia & $\mathrm{GO}$ & 35 & 747 & 0,08 & 30.000 & complexo \\
\hline 9 & Internacional Pres. Castro Pinto & João Pessoa & PB & 34 & 65 & 0,07 & 20.000 & simples \\
\hline 10 & Orlando Bezerra de Menezes & Juazeiro do Norte & CE & 32 & 420 & 0,39 & 10.000 & simples \\
\hline 11 & Lauro Carneiro de Loyola & Joinville & SC & 23 & 4 & 0,02 & 15.000 & simples \\
\hline 12 & Gov. José Richa & Londrina & PR & 24 & 560 & 0,80 & 35.000 & complexo \\
\hline 13 & Internacional Zumbi dos Palmares & Maceió & $A L$ & 31 & 115 & 0,26 & 60.000 & complexo \\
\hline 14 & Internacional Alberto Alcolumbre & Macapá & AP & 33 & 14 & 0,03 & 20.000 & simples \\
\hline 15 & Internacional Min. Victor Konder & Navegantes & SC & 29 & 5 & 0,02 & 22.000 & simples \\
\hline 16 & Brig. Lysias Rodrigues & Palmas & TO & 29 & 228 & 0,60 & 24.000 & simples \\
\hline 17 & Senador Nilo Coelho & Petrolina & PE & 33 & 382 & 0,09 & 20.000 & simples \\
\hline 18 & Gov. Jorge Teixeira de Oliveira & Porto Velho & $\mathrm{RO}$ & 34 & 87 & 0,01 & 18.000 & complexo \\
\hline 19 & Plácido de Castro & Rio Branco & AC & 33 & 187 & 0,51 & 25.000 & simples \\
\hline 20 & Internacional Gilberto Freire & Recife & $\mathrm{PE}$ & 33 & 10 & 0,02 & 110.000 & complexo \\
\hline 21 & Santos Dumont & Rio de Janeiro & RJ & 29 & 3 & 0,02 & 60.000 & complexo \\
\hline 22 & Internacional Mal. Cunha Machado & São Luís & MA & 32 & 49 & 0,45 & 35.000 & complexo \\
\hline 23 & Internacional Mtro. Wilson Fonseca & Santarém & $\mathrm{PA}$ & 33 & 56 & 0,08 & 30.000 & simples \\
\hline 24 & Congonhas & São Paulo & SP & 28 & 800 & 0,28 & 75.000 & complexo \\
\hline 25 & Sem. Petrônio Portella & Teresina & $\mathrm{Pl}$ & 29 & 63 & 0,35 & 15.000 & simples \\
\hline 26 & Ten. Cel. Av. César Bombonato & Uberlândia & MG & 27 & 941 & 0,06 & 15.000 & simples \\
\hline 27 & Eurico de Aguiar Salles & Vitória & ES & 32 & 8 & 0,24 & 30.000 & complexo \\
\hline
\end{tabular}

Fonte: Elaboração própria, com base em DECEA (2019) e INFRAERO (2018b)

${ }^{6}$ PPD - Pista de pouso e decolagem; PEA - Pátio de estacionamento de aeronaves. 
Na sequência são descritas as características e suas respectivas influências para o estudo desenvolvido, apontadas no Quadro 3 (temperatura de referência, altitude, declividade longitudinal da PPD, área do PEA e sistema de Pistas de táxi).

Complementando, segundo BRASIL (2017), em 2016, os voos domésticos correspondiam a $85 \%$ do mercado de transporte aéreo brasileiro, sendo os $15 \%$ restantes voos internacionais, com destino ou partida do Brasil. Na sequência as principais características dos aeroportos listados no Quadro 3 são sintetizadas.

\subsubsection{Capacidade de atendimento de passageiros e demanda atendida}

A capacidade de atendimento é um fator indicado pelo operador aeroportuário. Com base no projeto e planejamento das operações, declara-se a capacidade de atendimento de determinado aeroporto. Trata-se da quantidade anual de passageiros embarcando e desembarcando que determinado aeroporto suporta.

A capacidade de atendimento de cada aeroporto é uma informação que pode ser utilizada para diversas parametrizações, desde a definição da quantidade de vagas de estacionamento, área do Edifício Terminal de Passageiros (TPS), até a área do Pátio de estacionamento de aeronaves (PEA).

Considerando o exposto no Apêndice A, a capacidade média dos aeroportos caracterizados é de aproximadamente 5.400.000 passageiros/ano e a demanda média atendida foi de 2.850.000 passageiros/ano, conforme INFRAERO (2018b). Tal fato leva à conclusão de um uso médio de $52 \%$ da capacidade instalada da rede de aeroportos.

Em síntese, os aeroportos brasileiros, com raras exceções, como o Aeroporto de Congonhas, em São Paulo e Santos Dumont, no Rio de Janeiro, que operam no limite ou acima de suas capacidades, apresentam superdimensionamento da infraestrutura instalada. 


\subsubsection{Temperatura de referência}

Segundo ANAC (2018b), a temperatura de referência do aeródromo é a média mensal das temperaturas máximas diárias para o mês mais quente do ano (sendo que o mês mais quente será o mês com maior temperatura mensal média).

Considerando o exposto no Quadro 3, para o propósito deste trabalho, foi empregada como temperatura de referência para o desenvolvimento do modelamento a temperatura média de referência dos aeroportos caracterizados, cujo valor encontrado foi de $31^{\circ} \mathrm{C}$.

Como estão sendo tratados apenas aeroportos em território brasileiro, a temperatura de referência média obtida realmente reflete uma temperatura bastante adequada e comum no país.

\subsubsection{Altitude média}

O conhecimento da altitude, ou seja, da elevação do local do aeroporto em relação ao nível do mar, é muito importante na cadeira aeronáutica. A altitude média do sítio aeroportuário é um fator que influencia, de forma determinística, o comprimento de uma Pista de pouso de decolagem.

Conhecer esse parâmetro dos aeroportos caracterizados, permite traçar um panorama da influência da altimetria do relevo brasileiro na concepção dos aeroportos.

Com base nas informações presentes no Quadro 3, aplicando-se uma média simples, obtém-se que a altitude média em relação ao nível do mar dos aeroportos caracterizados é de 249 m, indicando as baixas elevações do território brasileiro.

Complementando, vale uma consideração sobre o relevo brasileiro. Sua estrutura geológica é bastante antiga, o que determina um relevo com baixas altitudes. A inexistência de dobramentos modernos e a ação erosiva pelas qual já passaram os 
escudos cristalinos favoreceu o processo de erosão, ocasionando as baixas altitudes médias (IBGE, 2012).

\subsubsection{Declividade longitudinal da Pista de pouso e decolagem}

A declividade longitudinal das Pista de pouso e decolagem (PPD) merece atenção, visto influenciar no desempenho das aeronaves, quando em operações de pousos e decolagens.

Pista com "subida" exige maior comprimento de PPD para atingimento da velocidade de sustentação para alçar voo, bem como pista com "descida" exige mais das aeronaves para parada.

Todos os aeroportos caracterizados estão dentro do que preconizam os normativos internacionais e nacionais sobre o assunto. Segundo ANAC (2018b), para a classificação dos aeroportos em questão, admite-se uma declividade longitudinal máxima de $1,50 \%$.

Segundo as informações do Quadro 3, a declividade longitudinal média das PPD dos aeroportos caracterizados é de $0,22 \%$.

Ainda que seja um valor dentro dos normativos especificados, o ideal, segundo a literatura especializada, é que a mesma seja nula ou próxima de $0 \%$, de forma a obterem-se comprimentos de PPD otimizados, como adiante será detalhado neste trabalho.

\subsubsection{Pátio de estacionamento de aeronaves}

Para estabelecer uma modelagem do custo de construção dessa superfície pavimentada, a área destinada ao Pátio de estacionamento de aeronaves (PEA) de cada aeroporto foi levantada. 
Com base nas informações do Quadro 3, a área média de um PEA, dos aeroportos caracterizados, é de aproximadamente $37.000 \mathrm{~m}^{2}$ por empreendimento.

Também foi caracterizado o material de revestimento da pavimentação aplicado aos PEA. Constatou-se que todos os pátios destinados ao estacionamento de aeronaves dos aeroportos caracterizados apresentam pavimentação rígida com placas de concreto.

Segundo a gerência de obras da INFRAERO, esse material é empregado, nesses pátios, devido a menores intervenções para manutenção ao longo da vida útil do pavimento, ainda que apresente considerável custo maior de construção em relação à pavimentação flexível.

Destaca-se, ainda, que o emprego desse material em um PEA é feito, pois, em algumas porções do pátio, ocorrem uma maior densidade de tráfego, lenta movimentação ou mesmo da parada das aeronaves, o que ocasiona níveis de compressão maiores do que na pista de pouso e decolagem no pavimento (ANAC, 2018b).

\subsubsection{Pistas de táxi}

Todos os aeroportos caracterizados, por receberem aeronaves de médio e grande porte, apresentam Pistas de táxi (PTX) pavimentadas. Dentre os 27 aeroportos, 13 apresentam Sistemas Complexos de Pistas de Táxi, com pista paralela e saídas rápidas. Os demais apresentam Sistemas Simples de Pistas de Táxi, no qual o acesso entre Pista de pouso e decolagem e Pátio de estacionamento de aeronaves é realizado diretamente por único acesso.

Também foi caracterizado o material de revestimento da pavimentação aplicado às PTX. Constatou-se que todas PTX dos aeroportos caracterizados apresentam pavimentação flexível com revestimento asfáltico. 


\subsubsection{Pistas de pouso e decolagem}

Todos os aeroportos caracterizados, por receberem aeronaves de médio e grande porte, apresentam pistas de pouso e decolagem (PPD) pavimentadas. Dentre os 27 aeroportos, 6 apresentam duas PPD, e os demais apenas uma PPD. No entanto, comumente, frente às demandas não muito elevadas do mercado de transporte aéreo brasileiro ${ }^{7}$, apenas uma PPD, tida como "principal" nos aeródromos que possuem duas PPD, é empregada nas operações regulares da aviação comercial. A pista secundária acaba sendo operada apenas por aeronaves menores ou em ocasiões de obras e manutenção na pista principal.

Dessa forma, para a quase totalidade da realidade operacional dos aeroportos brasileiros, apenas uma PPD é suficiente e adequada para suportar as demandas. Este fato motivou o modelamento desenvolvido para apenas uma PPD por aeroporto, não sendo discutida a necessidade de duas PPD.

Segundo Wells e Young (2014), duas PPD são impositivas para aeroportos com volumes de decolagens a partir da casa de 270.000 ao ano, número muito distante para o mercado da aviação civil brasileira.

Fato bastante característico que foi levado para a modelagem desenvolvida, é que todas as PPD dos aeroportos caracterizados apresentam pavimentação flexível com revestimento asfáltico.

Tal fato, segundo especialistas da Superintendência de Infraestrutura Aeroportuária da Agência Nacional de Aviação Civil, deve-se ao menor custo de construção de pistas com esse material em comparação com a pavimentação rígida, além de prazos menores para execução e do relativo domínio construtivo das técnicas de pavimentação asfálticas no Brasil.

Uma análise quanto à resistência dos pavimentos também foi efetuada e, nesse caso, como a resistência do pavimento é função direta da aeronave de projeto a ser

\footnotetext{
${ }^{7}$ Quando comparada às demandas pelo transporte aéreo em mercados desenvolvidos como Estados Unidos da América e países da União Europeia.
} 
empregada em determinada operação, verificou-se que todos os aeroportos suportam as aeronaves que são indicadas para operar nas diferentes localidades ${ }^{8}$.

\subsection{CARACTERIZAÇÃO DAS FROTAS DE AERONAVES DAS COMPANHIAS AÉREAS BRASILEIRAS}

Para a caracterização da frota de aeronaves que operam no mercado doméstico brasileiro de transporte aéreo, foi realizada uma pesquisa onde ponderou-se a participação do mercado de cada companhia aérea.

Através do conhecimento dos modelos de aeronaves operados pelas mesmas, podese estabelecer um conjunto de aeronaves a ser considerado nas modelagens que foram efetuadas. Esse tipo de constatação é interessante, visto que um empreendedor ou planejador da área aeroportuária, seja ele da esfera pública ou privada, dificilmente conhece qual ou quais aeronaves irão operar em determinada localidade, cabendo essa adequação e destinação exclusivamente às companhias aéreas, que, através de estudos de viabilidade e análises próprias, destinam determinado modelo de aeronave a atender determinada localidade.

Visando atender ao escopo do estudo desenvolvido, considerando-se um empreendimento aeroportuário situado no território brasileiro, destinado exclusivamente a operações domésticas, este será atendido por uma das companhias aéreas que operam domesticamente no país.

Com isso, conhecer as frotas de aeronaves dessas companhias, permite estabelecer as opções de modelos de aeronaves que logicamente serão empregadas no atendimento de determinado aeroporto exclusivamente doméstico.

\footnotetext{
${ }^{8}$ Analisou-se o PCN - Pavement Classification Number de cada superfície pavimentada frente ao ACN - Aircraft Classification Number de cada modelo de aeronave tipicamente operada em cada aeroporto. O método ACN/PCN é preconizado pela ICAO e está presente nos manuais de operação das aeronaves fornecidos pelos fabricantes.
} 
Para essa determinação, considerou-se também a participação de cada companhia aérea no mercado de transporte aéreo brasileiro. A Figura 25 apresenta a evolução da participação das principais companhias aéreas que operam no mercado de transporte aéreo doméstico brasileiro.

Figura 25 - Participação das companhias aéreas no mercado doméstico brasileiro de transporte aéreo

Fonte: ANAC (2019b)

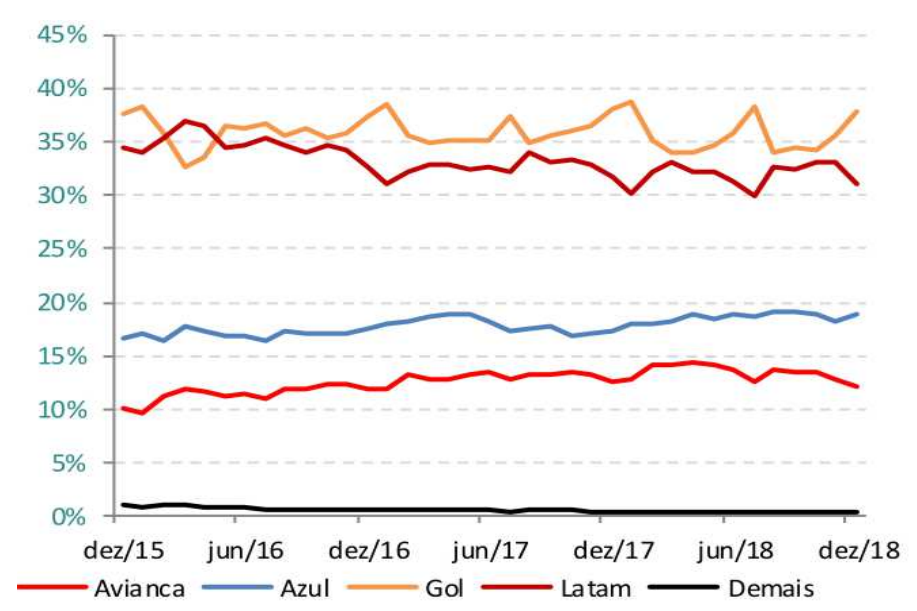

Considerando informações relativas ao final de 2018, ANAC (2019b), a companhia aérea Gol Linhas Aéreas Inteligentes apresenta-se como líder do mercado, com 35,7\% de participação, seguida pela Latam Airlines Brasil com 31,9\%, Azul Linhas Aéreas Brasileiras, com 18,6\%, e Avianca Brasil, com 13,4\%. Existem ainda companhias aéreas de menor porte, muitas vezes operando exclusivamente regionalmente no território. A participação no mercado dessas empresas menores é $0,40 \%$.

Conhecendo esse panorama, analisaram-se as frotas das 4 principais companhias aéreas, que respondem por 99,60\% de participação nesse mercado, considerando as empresas em operação em 2018.

Iniciando-se pela Gol Linhas Aéreas Inteligentes, segundo dados da ANAC (2018c), a empresa opera um único modelo de aeronave com duas variantes de projeto. Tratase da aeronave modelo B737, fabricada pela The Boeing Company. São cerca de 120 aeronaves registradas, sendo 96 da variante modelo B737-800 e 24 da variante modelo B737-700. 
Ressalta-se que o número exato de aeronaves que compõem as frotas das companhias aéreas não pode ser considerado fixo, visto que aeronaves são incorporadas, excluídas ou entram em ciclos de manutenção; no entanto, os números apresentados permitem, de forma adequada, caracterizar as frotas das companhias aéreas para fins deste estudo.

A Latam Airlines Brasil, por sua vez, segundo dados da ANAC (2018c), opera três modelos de aeronaves em suas operações domésticas. Trata-se das aeronaves modelos A319-100, A320-200 e A321-200, fabricadas pela Airbus S.A.S. São cerca de 110 aeronaves registradas, sendo 20 A319-100, 60 A320-200 e 30 A321-200.

Já a Azul Linhas Aéreas Brasileiras, segundo dados da ANAC (2019), opera quatro modelos de aeronaves em suas operações domésticas. Trata-se das aeronaves modelos A320neo, fabricado pela Airbus S.A.S., E190, E195, fabricadas pela Embraer S.A. e ATR72-600, fabricada pela Avions de Transport Régional. São cerca de 123 aeronaves registradas, sendo 24 A320neo, 9 E190, 60 E195 e 30 ATR72-600.

Por fim, a Avianca Brasil, segundo dados da ANAC (2018c), opera três modelos de aeronaves em suas operações domésticas. Trata-se das aeronaves modelos A318, A319-100 e A320-200, fabricadas pela Airbus S.A.S. São cerca de 40 aeronaves registradas, sendo 4 A318, 4 A319-100 e 32 A320-200.

\subsection{CARACTERIZAÇÃO DAS AERONAVES MAIS OPERADAS NOS AEROPORTOS BRASILEIROS}

Considerando toda a exposição da seção anterior, verifica-se, com base nos levantamentos efetuados e também segundo reportes de agentes da Superintendência de Serviços Aéreos da Agência Nacional de Aviação Civil, que as aeronaves mais operadas na malha doméstica, considerando-se dados do ano de 2018, são os modelos: B737-800, A320-200 e E195. 


\subsubsection{Características das aeronaves que influenciam no dimensionamento dos elementos pavimentados de um aeroporto}

$\mathrm{Na}$ caracterização das aeronaves, para as modelagens efetuadas neste trabalho, alguns aspectos necessitam ser obtidos para definição de fatores a serem parametrizados, dentre eles o dimensionamento da Pista de pouso e decolagem (PPD) e Pistas de táxi (PTX).

O comprimento e largura das superfícies pavimentadas são definidos em função dos modelos de aeronaves que serão operadas em determinado aeroporto, ou seja, devese conhecer a aeronave mais restritiva - aeronave de projeto, que demande as instalações mais robustas e com maior porte.

Uma vez que o equipamento aeroportuário comporte a aeronave de projeto, comporta com folga os demais modelos, menos restritivos dentre um conjunto de aeronaves a ser operado.

Em síntese, para dimensionamento físico de uma Pista de pouso e decolagem (PPD), necessita-se estabelecer o comprimento e largura da mesma e, para tanto, é necessário conhecer:

- O peso de decolagem considerado da aeronave de projeto: peso da aeronave acrescido dos fluidos (óleos lubrificantes, aditivos e combustível), tripulantes, passageiros, bagagens, cargas e elementos de comissaria;

- A temperatura de referência da localidade;

- A altitude de implantação da PPD;

- A intensidade e direção dos ventos predominantes; e

- A declividade longitudinal da PPD.

Para dimensionamento físico das Pistas de táxi (PTX), suas dimensões serão obtidas em função da aeronave de projeto a ser operada no aeroporto. 
Já quanto ao Pátio de estacionamento de aeronaves (PEA), o dimensionamento também é realizado a partir das aeronaves que serão operadas no aeroporto, concentração de demandas em horários de pico e outros fatores operacionais específicos de cada localidade de aeroporto.

O tamanho desses pátios também é função da existência de terminais cargueiros no aeroporto em questão, uma vez que esse tipo de operação demanda mais tempo de estacionamento e uso da infraestrutura instalada.

Complementando as definições básicas envolvidas, é interessante ao leitor: o peso de decolagem é o peso da aeronave no momento inicial da operação de decolagem. Trata-se do peso operacional da aeronave pronta para operação, incluindo todos os fluidos necessários para o voo em questão, tripulantes, itens de comissaria, passageiros, bagagens e cargas.

Mas antes da apresentação dos pesos de decolagem de cada aeronave caracterizada para esse estudo, uma explanação é pertinente.

Existe o peso máximo de decolagem, que seria o peso limite estrutural de projeto da aeronave para alçar um voo sustentável; no entanto, dificilmente esse peso é empregado nas operações cotidianas, seja pela necessidade de combustível para determinada jornada não atingir a máxima capacidade dos tanques, seja pela taxa de ocupação dos assentos da aeronave não ser sempre $100 \%$, ou por outros fatores operacionais que se façam presentes.

Por isso, visando estabelecer o peso de decolagem de cada aeronave caracterizada de forma mais adequada e realista, foi empregada, como fator de cálculo do peso de decolagem, a taxa de ocupação de assentos das aeronaves.

Para as operações aéreas domésticas brasileiras, a taxa de ocupação dos assentos, no final 2018, segundo ANAC (2019b), situou-se em 81,3\%. A Figura 26 apresenta a evolução da taxa de ocupação dos assentos nas operações do mercado de transporte aéreo doméstico brasileiro nos últimos anos. 
Figura 26 - Taxa de ocupação dos assentos em operações domésticas brasileiras

Fonte: ANAC (2019b)

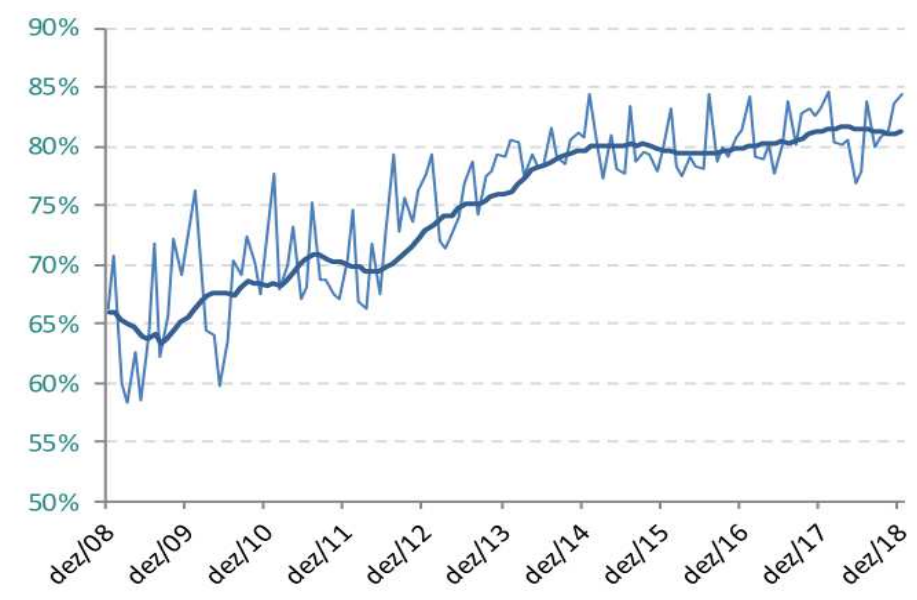

Com isso, na necessidade de se estabelecer uma variável empregada na modelagem paramétrica; avaliando recomendações de especialistas de gerências de engenharia de voo das principais companhias aéreas e a literatura especializada, situar o peso de decolagem da aeronave, como sendo o peso máximo de decolagem previsto no projeto do fabricante versus a taxa de ocupação dos assentos é bastante adequado.

No caso da modelagem em curso, a Equação 2 demonstra a forma como foi calculado o peso de decolagem de cada modelo de aeronave engajada no transporte exclusivamente em rotas aéreas domésticas brasileiras.

$$
\text { Peso }_{\text {decolagem }}=\text { Peso }_{\text {máx.decolagem }} \times 0,813(\mathrm{~kg})
$$

Na sequência, na Tabela 3, são apresentados os Pesos de decolagem das aeronaves empregados nesse trabalho

Tabela 3 - Peso de decolagem das aeronaves caracterizadas

\begin{tabular}{ccccc}
\hline $\begin{array}{c}\text { Aeronave } \\
\text { modelo }\end{array}$ & $\begin{array}{c}\text { Peso Máximo de } \\
\text { decolagem indicado } \\
\text { pelo fabricante (kg) }\end{array}$ & & $\begin{array}{c}\text { Taxa de } \\
\text { ocupação } \\
\text { considerada }\end{array}$ & $\begin{array}{c}\text { Peso de } \\
\text { decolagem } \\
\text { considerado (kg) }\end{array}$ \\
\hline B737-800 & 79.016 & & 64.240 \\
\hline A320-200 & 73.500 & $81,3 \%$ & 59.756 \\
\hline E195 & 48.790 & & 39.666 \\
\hline
\end{tabular}

Fonte: Elaboração própria, com base em informações dos fabricantes - AIRBUS S.A.S. (2019); BOEING COMMERCIAL AIRPLANES (2018); EMBRAER (2019) 


\subsection{CARACTERIZAÇÃO DA PAVIMENTAÇÃO AEROPORTUÁRIA}

Para dimensionamento da estrutura do pavimento, além de fatores como cargas incidentes sobre o pavimento, intensidade do tráfego e clima, o conhecimento das características do solo original (subleito para construção do pavimento) é muito relevante.

A literatura especializada indica forte influência do tipo de solo do local para o projeto de pavimentos. Considerando que o solo original (subleito) define, em grande parte, a estrutura (espessura) das camadas que compõem o pavimento aeroportuário, vale conformar um cenário aplicado aos projetos dessa cadeira em todo o mundo, inclusive seguindo as especificações dos fabricantes de aeronaves.

Nesse contexto, cabe discutir a caracterização da capacidade de suporte de um solo. Segundo Duran (2015), um pavimento aeroportuário deve possuir a capacidade de suporte necessária para resistir às cargas impostas pelo tráfego de aeronaves.

\subsubsection{Capacidade de suporte do subleito}

Um dos itens que interferem no dimensionamento da pavimentação aeroportuária é a resistência do subleito. Essa resistência é mensurada, para projetos de engenharia, segundo o CBR ou coeficiente de recalque do solo.

Dessa forma, a Tabela 4 apresenta os valores característicos e correlação de CBR (para dimensionamento de pavimentos flexíveis) e Coeficiente de recalque - $\mathrm{k}$ (para dimensionamento de pavimento rígidos).

Tabela 4 - Valores característicos para capacidade de suporte do subleito na pavimentação aeroportuária

\begin{tabular}{ccc}
\hline $\begin{array}{c}\text { Categoria de } \\
\text { resistência do Subleito }\end{array}$ & CBR (\%) & $\begin{array}{c}\text { Coeficiente de recalque } \\
\text { "k" }\left(\mathbf{M N} / \mathbf{m}^{3}\right)\end{array}$ \\
\hline Alta & 15 & 150 \\
\hline Média & 10 & 80 \\
\hline Ultra baixa & 3 & 20 \\
\hline
\end{tabular}

Fonte: Elaboração própria 
Foi necessário aplicar essa correlação, visto que para projetos considerando o pavimento flexível, emprega-se o CBR do solo, enquanto que, para projetos considerando o pavimento rígido, emprega-se o Coeficiente de recalque $(k)$. Essa correlação é amplamente apresentada em diversas referências da literatura especializada de pavimentação.

Como balizador, na área de pavimentos, a determinação sobre a qualidade estrutural de um solo é tomada mais frequentemente pelo seu CBR (California Bearing Ratio), em forma livre para o português - ISC (Índice de Suporte Califórnia).

Ainda, segundo o Highway Research Bureau, órgão norte-americano de pesquisa e desenvolvimento na área de pavimentos, um solo considerado bom tem seu CBR entre $10 \%$ e $20 \%$ e um solo muito pobre entre $0 \%$ e $3 \%$, em termos de resistência. 


\section{DESENVOLVIMENTO DO MODELO PARAMÉTRICO PARA ESTIMATIVA DOS CUSTOS DE CONSTRUÇÃO DAS SUPERFÍCIES PAVIMENTADAS PARA OPERAÇÃO DE AERONAVES EM AEROPORTOS}

Baseando-se nas premissas desse trabalho, apenas com informações preliminares, buscou-se uma forma de estimar os custos de construção das superfícies destinadas ao trânsito de aeronaves em um aeroporto.

De forma expedita, a Figura 27 apresenta a concepção paramétrica aplicada para o modelamento desenvolvido.

Figura 27 - Modelamento paramétrico

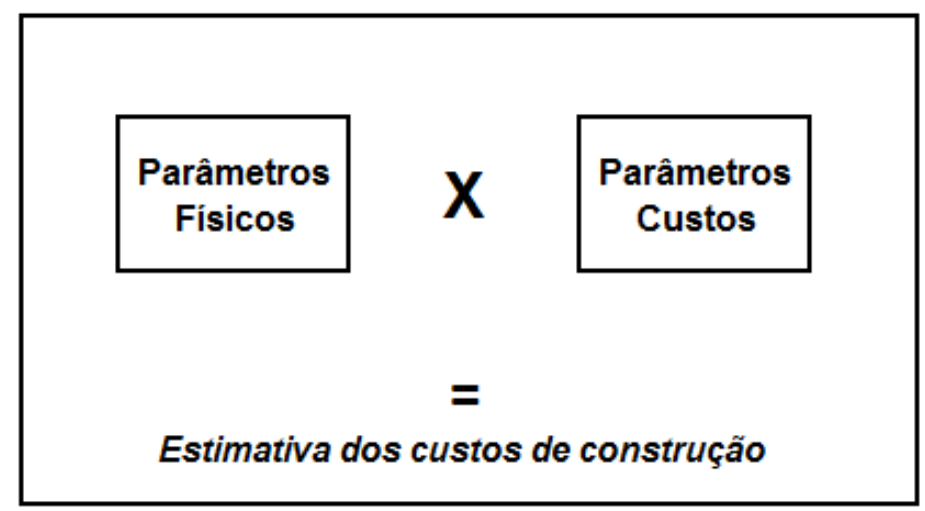

Fonte: Elaboração própria

Para se obter o custo das pavimentações aeroportuárias é necessário ter-se a quantidade a ser executada (área a ser revestida), a estrutura e o tipo de revestimento e o custo unitário deste revestimento. Com base nestas quantidades definidas, utilizam-se preços unitários para, na multiplicação de ambos, obter-se o custo.

Com base na literatura especializada sobre planejamento e design de aeroportos, conhecimentos obtidos através de entrevistas com especialistas da área (construtores e planejadores de infraestrutura aeroportuária), pilotos de aeronaves e responsáveis pela área de engenharia de operações das principais companhias aéreas brasileiras, além dos conhecimentos do autor acumulados em mais de uma década atuando na aviação civil, um conjunto com os principais parâmetros que influenciam no 
dimensionamento de um aeroporto foi definido e apresentado na sequência deste Capítulo.

\subsection{PARAMETRIZAÇÕES APLICADAS NO MODELAMENTO}

Quando se estuda a viabilidade de um empreendimento de construção civil, geralmente dispõe-se apenas de algumas informações; dentre elas certamente destaca-se a localidade de implantação, seja região, área delimitada para determinada utilidade ou, até mesmo, no melhor dos casos, o terreno propriamente destinado à construção em questão.

No caso de locais para implantação de aeroportos, conhecer aspectos gerais da localidade onde estuda-se construir é de suma importância, uma vez que a operação de aeronaves está diretamente ligada a questões físicas de um determinado local.

Além disso, conhecer custos de terrenos para o sítio aeroportuário, disponibilidade de materiais de construção, equipamentos e mão de obra, além de características culturais e econômicas da região, é algo importante, pois estas características determinam vocações e propriedades específicas a serem atendidas com o projeto.

Na sequência são apresentadas as parametrizações aplicadas ao modelamento desenvolvido.

\subsubsection{Altitude da localidade}

A determinação da elevação média do terreno onde será estudada a implantação da pista de um aeroporto é determinante para estabelecimento do comprimento da pista de pouso e decolagem (PPD), uma vez que, quanto maior a altitude da localização do aeroporto, menos densa será a atmosfera. 
Esse fato impõe menor quantidade de oxigênio disponível para combustão nos motores, levando a aeronave a precisar de maior comprimento de pista para alcançar a velocidade que Ihe ofereça sustentação suficiente para decolar.

No modelo desenvolvido, qualquer altitude pode ser considerada na parametrização, uma vez que constitui uma informação preliminar para alimentação como dado de entrada do modelo.

\subsubsection{Capacidade de suporte do subleito (solo original)}

Conforme apresentado na Seção 4.4, o tipo de solo original determina a capacidade de suporte do mesmo. Dessa forma, a capacidade de suporte influencia diretamente a estrutura do pavimento a ser construído, ou seja, as espessuras de cada camada que compõe o pavimento aeroportuário.

No modelo desenvolvido, qualquer capacidade de suporte do subleito (CBR) pode ser considerada na parametrização, uma vez que constitui uma informação preliminar para alimentação como dado de entrada do modelo.

\subsubsection{Forma de atendimento da demanda}

Aeroportos localizados junto a grandes centros urbanos ou regiões metropolitanas com alto adensamento populacional, como o caso dos aeroportos de Congonhas (São Paulo), Santos Dumont (Rio de Janeiro) e algumas outras capitais de estados, tendem a apresentar concentração de demanda em determinadas horas do dia.

Tomando-se como exemplo os aeroportos de Congonhas e Santos Dumont, que interligam o principal eixo econômico e populacional do país, frequentando-se tais instalações, verifica-se facilmente que, nas primeiras horas do dia e no início da noite, grande concentração de movimentação de aeronaves ocorre. Esse fato gera uso intensivo das Pistas de pouso e decolagem (PPD), Pistas de táxi (PTX) e Pátio de estacionamento de aeronaves (PEA). 
Para isso, ao invés de um sistema com um simples acesso entre PPD e PEA é criado um sistema com múltiplos acessos, incluindo Pistas de táxi rápidas e em número que permita que as aeronaves utilizem o menor tempo possível entre saída do PEA e corrida para decolagem na PPD ou o inverso, isto é, assim que pousam na PPD podem rapidamente sair para o PEA.

Logicamente um sistema complexo de Pistas de táxi tem custo de construção bastante significativo, haja vista o grande aumento de áreas a receberem pavimento estruturalmente preparado.

Já em aeroporto com poucas movimentações de aeronaves ou com demanda distribuída ao longo das horas do dia, sistemas de único acesso, perpendicular entre PPD e PEA já são suficientes.

A Figura 28 ilustra as diferenças entre o Sistema Complexo de Pistas de Táxi, para atendimento de demanda concentrada em horários de pico, e um Sistema Simples de Pista de Táxi, para casos com pequena demanda ou demanda distribuída ao longo do dia.

Figura 28 - Sistemas de Pistas de táxi considerando forma de atendimento da demanda

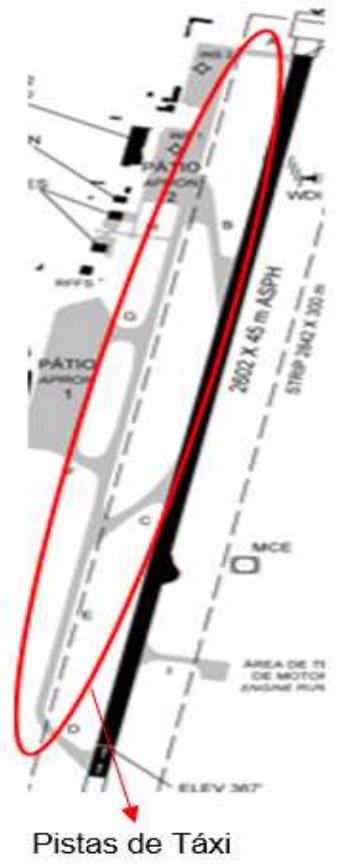

(a) Sistema Complexo de Pistas de Táxi

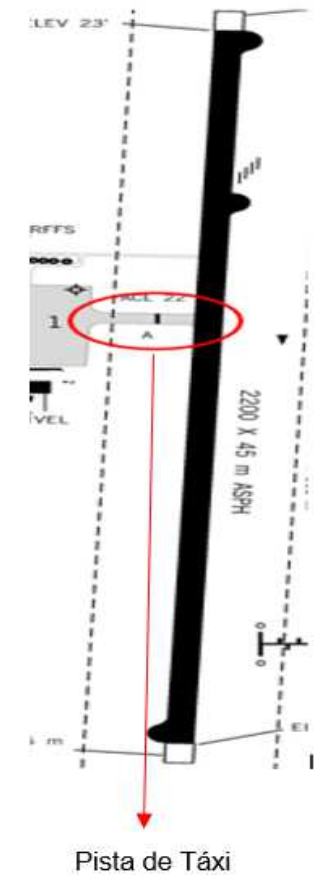

(b) Sistema Simples de Pista de Táxi

Fonte: Elaboração própria, com base em DECEA (2019) - Adaptado 
No modelo desenvolvido, a indicação por um sistema complexo ou simples de Pista de táxi constitui uma informação preliminar para alimentação como dado de entrada do modelo, essa opção é embasada na forma de atendimento da demanda de determinado aeroporto.

\subsubsection{Demanda}

A demanda a ser atendida por um aeroporto indica o volume de passageiros embarcando ou desembarcando em determinado ano, no caso de um aeroporto destinado ao transporte de passageiros.

No caso de um aeroporto destinado a operações com cargas aéreas, a demanda é indicada através do volume de carga transportada.

Esta informação também estabelece relação com o dimensionamento de praticamente todos os elementos que compõem um aeroporto.

Pensando-se principalmente nas superfícies pavimentadas para operação de aeronaves, a demanda apresenta maior representatividade, visto apresentar-se influente no dimensionamento da estrutura da pavimentação - quanto maior o trânsito e porte das aeronaves engajadas nas operações aéreas, maiores espessuras de pavimentação são requeridas.

No modelo desenvolvido, qualquer demanda pode ser considerada na parametrização, uma vez que constitui uma informação preliminar para alimentação como dado de entrada do modelo.

\subsubsection{Aeronave de projeto}

Para dimensionamento dos elementos planos pavimentados de um aeroporto, 0 conhecimento da aeronave de projeto, ou seja, a mais restritiva em termos 
operacionais, que demanda os maiores dimensionamentos, tanto das grandezas físicas quanto estruturais da pavimentação, é determinante.

Para tanto, é necessário estabelecer o conjunto de aeronaves que serão operadas no aeroporto. Esse tópico já foi detalhado anteriormente nesse trabalho; por isso, essa seção foca na fase de cálculos e forma sob a qual é determinada a aeronave de projeto, que determinará as parametrizações para composição da modelagem.

Como anteriormente descrito nesse trabalho, um conjunto adequado de modelos de aeronaves, que atendem o mercado de transporte aéreo brasileiro, é determinado pelos modelos B737-800, A320-200 e E195; dessa forma, o conjunto a ser utilizado nas modelagens desse trabalho levou em consideração esses modelos de aeronaves.

Com base em procedimentos e dados gráficos presentes nos respectivos manuais das aeronaves elaborados pelos seus fabricantes, presentes em AIRBUS S.A.S. (2019), BOEING COMMERCIAL AIRPLANES (2018) e EMBRAER (2019), apurou-se os comprimentos de Pista de pouso e decolagem (PPD) requeridos para cada modelo de aeronave.

Para a aeronave modelo B737-800, chegou-se a um comprimento de PPD "básico" de $1.500 \mathrm{~m}$, para a A320-200, $1.220 \mathrm{~m}$ e para a E195, $1.170 \mathrm{~m}$, para as condições impostas nesse estudo.

Os comprimentos básicos são grandezas obtidas em gráficos para condições consideradas "padrão" na aviação civil - temperatura de referência da localidade de $15 \stackrel{\circ}{ } \mathrm{C}$; PPD com declividade longitudinal nula; ventos nulos e altitude do aeroporto ao nível do mar. Quanto ao peso de decolagem da aeronave, como dado de entrada nessa análise, no caso, situou-se peso de decolagem como sendo $81,3 \%$ do peso máximo de decolagem de cada modelo de aeronave, vide o exposto na seção 4.3.1 (Tabela 3).

Quanto à largura, as três aeronaves mais operadas no mercado aéreo doméstico brasileiro enquadram-se na mesma classificação geométrica, requerendo largura de $45 \mathrm{~m}$, sem necessidade de acostamentos. 
Com isso, a aeronave de projeto, que determinará as parametrizações do modelo de custos desenvolvido, é a modelo B737-800, por apresentar maior comprimento de PPD necessário para operação.

\subsubsection{Temperatura de referência}

No presente trabalho, fruto da caracterização dos aeroportos anteriormente apresentada, será tomada como temperatura média de referência, a temperatura média obtida dentre todos os aeroportos caracterizados.

\subsubsection{Ventos predominantes}

A definição para escolha de um sítio aeroportuário conta também com um minucioso estudo sobre a direção e intensidade dos ventos predominantes na região.

Ventos que incidem sobre a popa ou proa da aeronave determinam comprimentos de pista, lado de operação das cabeceiras e até mesmo limitações sobre possibilidade de ocorrência de operações aéreas ou não (HORONJEFF et al, 2010).

No entanto, como forma mais conservadora e aplicada ao projeto de aeródromos, considera-se que a incidência de ventos é nula (FAA, 2005). Com isso, essa variável é fixada como nula na modelagem dos parâmetros físicos neste trabalho.

\subsubsection{Declividade longitudinal da Pista de pouso e decolagem}

A declividade longitudinal de uma Pista de pouso e decolagem (PPD), quanto maior, requer maior comprimento seu. Idealmente a declividade deve ser nula ou próxima a 0\%; no entanto, impor esse tipo de restrição, pode muitas vezes acarretar em volumes significativamente maiores de terraplenagem necessária. 
Porém, como não é possível conhecer com detalhes a topografia de um terreno, sem uma ampla campanha de levantamentos topográficos, considera-se que a PPD será totalmente nivelada e apresentará declividade longitudinal nula, nas modelagens desenvolvidas.

Em tempo, também, a modelagem considerou implantação das superfícies pavimentadas escopo do trabalho, como niveladas, sem necessidade de movimentos de terra significativos para construção da PPD.

\subsubsection{Taxa de crescimento do mercado de aviação civil}

Como um projeto atende a um horizonte de tempo, segundo um planejamento específico, é necessário o conhecimento do incremento de operações que ocorrerá nesse horizonte de tempo.

Numa data futura, dentro do horizonte de projeto, considerando-se cenários de desenvolvimento e crescimento (aplicados na área aeroportuária), o tráfego de aeronaves certamente será maior que na data presente.

A taxa de crescimento do mercado de aviação civil brasileiro situa-se em 3,35\% ao ano, sendo este um cenário conservador, segundo BRASIL (2017). Para fins deste trabalho, fica estabelecido este valor.

\subsection{DETERMINAÇÃo dOS PARÂMETROS FísICOS PARA APLICAÇÃO NO MODELAMENTO}

\subsubsection{Comprimento da Pista de pouso e decolagem}

O comprimento de uma Pista de pouso e decolagem (PPD) leva em consideração diversos parâmetros. As aeronaves precisam de uma distância mínima para acelerar 
até a decolagem e para desacelerar após a aterrissagem; com isso, comprimentos específicos são requeridos para acomodar as operações com aeronaves.

As características que determinam o comprimento de uma PPD incluem especificações de desempenho das aeronaves a serem atendidas, peso de decolagem, taxa de aceleração, altitude e temperatura de referência do ar (YOUNG; WELLS, 2014).

Nesse trabalho foi seguido o previsto na FAA (2005), para estimar o comprimento de uma PPD. Para determinar o comprimento requerido de uma PPD, fora das condições padrão indicadas pelos fabricantes de aeronaves (que seria temperatura de referência $15^{\circ} \mathrm{C}$, ventos nulos, altitude ao nível do mar e declividade longitudinal da PPD nula), qualquer variação em alguns dos fatores supracitados gera incremento no comprimento da PPD, o que ocorre sempre em situações operacionais nas diversas localidades dos aeroportos.

Para esses incrementos e cálculo do comprimento da PPD realmente necessário para as operações seguras das aeronaves, fatores de correção são aplicados.

São os fatores de correção de comprimento de uma PPD recomendados pela ICAO (2004):

- Fator de correção devido à altitude ( $\left(\mathrm{FC}_{\text {alt }}\right)$ : acrescentar $7 \%$ de comprimento para cada $300 \mathrm{~m}$ de altitude superior ao nível do mar;

- Fator de correção devido à temperatura de referência $\left(\mathrm{FC}_{\text {temp }}\right)$ : acrescentar $1 \%$ de comprimento para cada $1^{\circ} \mathrm{C}$ de diferença entre a temperatura de referência do local e a temperatura padrão empregada no dimensionamento "básico";

- Fator de correção devido à declividade (FC decliv): acrescentar $1 \%$ de comprimento para $0,1 \%$ de declividade longitudinal da PPD.

Com isso o Fator de Correção Global (FCglobal) é determinado segundo a Equação 3:

$$
F C_{\text {global }}=F C_{\text {alt }} \times F C_{\text {temp }} \times F C_{\text {decliv }}
$$


Seguindo as condições estabelecidas para esse trabalho, aplicando-se as parametrizações, determina-se o parâmetro físico - Comprimento da PPD, considerando:

- Aeronave de projeto: B737-800;

- Temperatura de referência: conforme localidade de implantação do aeroporto (para esse trabalho, fixada sendo uma média nacional);

- Altitude: conforme a localidade de implantação do aeroporto;

- Declividade longitudinal: nula;

- Ventos: nulos.

Sendo assim, a Tabela 5 apresenta o cálculo dos comprimentos de PPD, segundo a variação da altitude da região do aeroporto, considerando os Fatores de Correção citados nessa seção, para implantação de aeroportos no Brasil. O comprimento da PPD, aplicando-se o Fator de Correção Global é obtido segundo a Equação 4. O valor de LPPD básico está disposto na seção 5.1.5, no caso, 1.500 m:

$$
L_{P P D \text { calc. }}=F C_{\text {global }} \times L_{P P D \text { básico }}
$$

Tabela 5 - Comprimento das PPD segundo a altitude

\begin{tabular}{cccccc}
\hline Altitude (m) & FC alt & FC temp $_{\text {to }}$ & FC decliv $_{\text {div }}$ & FC $_{\text {global }}$ & $\begin{array}{c}\text { Comprimento da PPD } \\
\text { calculado (m) }\end{array}$ \\
\hline 0 & 1,0000 & 1,1600 & 1,0000 & 1,1600 & 1.740 \\
\hline 200 & 1,0467 & 1,1731 & 1,0000 & 1,2279 & 1.842 \\
\hline 400 & 1,0933 & 1,1862 & 1,0000 & 1,2970 & 1.945 \\
\hline 800 & 1,1867 & 1,2125 & 1,0000 & 1,4388 & 2.158 \\
\hline
\end{tabular}

Fonte: Elaboração própria, com base em ICAO (2004)

Para obtenção da equação de regressão linear para determinação do comprimento da PPD requerido, o Gráfico 1 apresenta a correlação entre esse comprimento em relação a altitude da localidade de implantação do aeroporto. 
A equação de regressão foi empregada, visto ser um artifício com acurácia adequada para o propósito e ainda definir uma forma adequada (através de uma equação) de correlacionar as informações de origem determinística.

Vale ressaltar, ainda, que a análise de regressão pode estabelecer a dependência entre duas ou mais variáveis, expressando os valores esperados de uma delas em função da outra (MOREIRA 2013 apud SEGURA, 1998). No caso, relaciona a dependência entre a altitude da localidade e comprimento requerido da PPD.

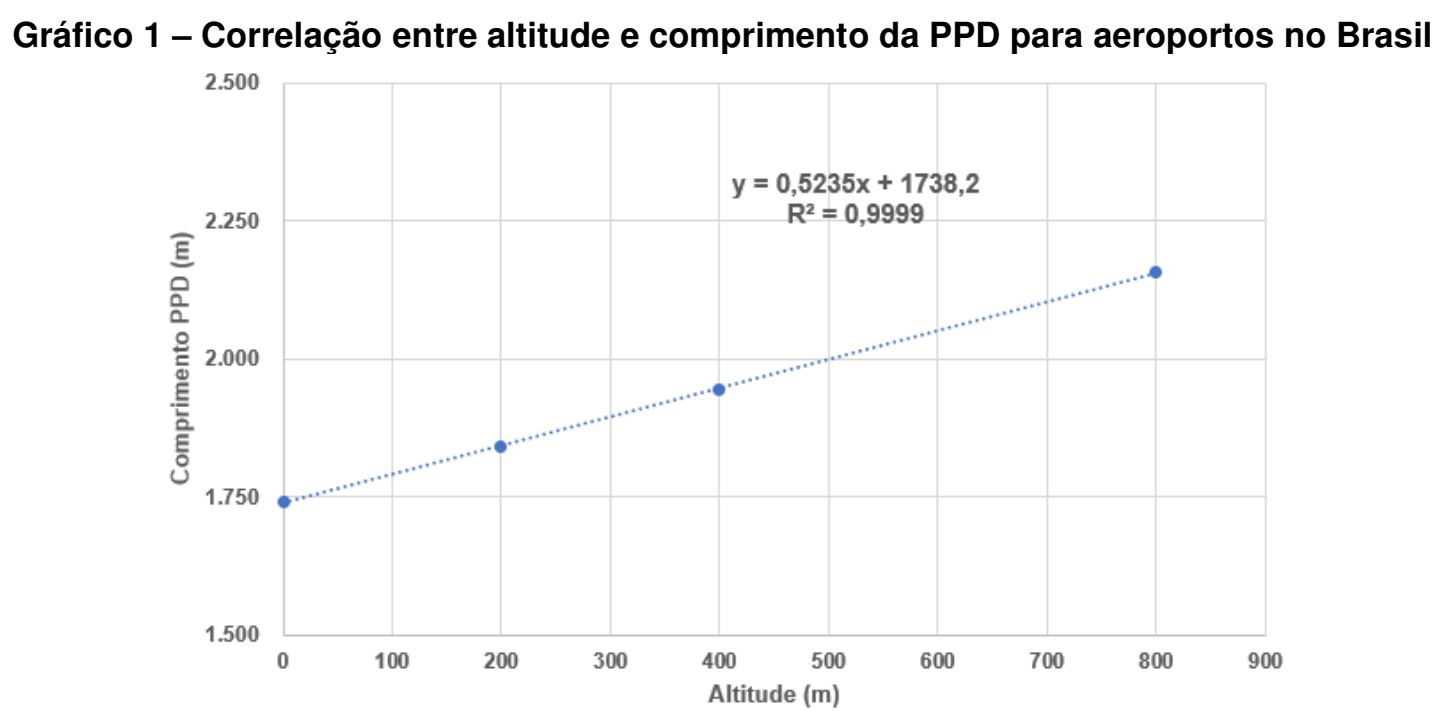

Fonte: Elaboração própria

Aplicando-se a regressão linear, variando-se a altitude, como fator paramétrico, a Equação 5 obtida da curva de tendência do Gráfico 1, permite determinação do parâmetro físico buscado, qual seja, Comprimento da PPD (LPPD).

$$
L_{P P D}=0,5235 \times \text { Altitude }_{\text {Aeroporto }}+1.738,2(\mathrm{~m})
$$

\subsubsection{Largura da Pista de pouso e decolagem}

A largura da Pista de pouso e decolagem (PPD) é determinada pelo projeto das aeronaves que serão servidas pelo aeroporto em questão. 
As larguras variam de $18 \mathrm{~m}$ a $60 \mathrm{~m}$ em aeroportos de uso público. A largura mais comum de uma PPD, para operações regulares comerciais das companhias aéreas em todo mundo, é de 45 m (YOUNG; WELLS, 2014).

A Tabela 6 apresenta as larguras requeridas para as PPD, segundo a classificação da aeronave (grupo da aeronave: quanto maior o número indicado, maior o porte; grupo geométrico: grandeza física definida em normativos conforme o porte da aeronave e características da operação), que realizará a operação.

Tabela 6 - Larguras requeridas para PPD (m)

\begin{tabular}{ccccccc}
\hline $\begin{array}{c}\text { Grupo da } \\
\text { aeronave }\end{array}$ & A & B & C & D & E & F \\
\cline { 2 - 8 } & 18 & 18 & 23 & - & - & - \\
\hline 1 & 23 & 23 & 30 & - & - & - \\
\hline 2 & 30 & 30 & 30 & 45 & & \\
\hline 3 & - & - & 45 & 45 & 45 & 60 \\
\hline 4 & & & & & &
\end{tabular}

Fonte: ICAO (2004)

Considerando a classificação do conjunto de aeronaves previsto nas operações domésticas brasileiras, verifica-se que todas essas aeronaves, apresentam mesmo enquadramento segundo a classificação de suas envergaduras - Aeronave Grupo 4 e Grupo Geométrico C (classificação: 4C).

Dessa forma, a largura da PPD para os aeroportos domésticos brasileiros, a que se destina o modelamento desenvolvido fica definida em $45 \mathrm{~m}$.

No entanto, ainda resta analisar a necessidade de acostamentos na PPD. Conforme o grupo geométrico de enquadramento das aeronaves que operarão em determinado aeroporto, acostamentos podem ou não serem requeridos. A Tabela 7 apresenta as larguras recomendadas para acostamento de uma PPD.

Tabela 7 - Larguras requeridas para acostamentos da PPD - de cada lado (m)

\begin{tabular}{cccccc}
\hline \multicolumn{7}{c}{ Grupo Geométrico } \\
\hline A & B & C & D & E & F \\
\hline- & - & - & 7,5 & 7,5 & 7,5 \\
\hline
\end{tabular}

Fonte: ICAO (2004) 
Como anteriormente citado, como as aeronaves em questão enquadram-se no Grupo Geométrico C - não são requeridos acostamentos nos aeroportos para operações exclusivamente domésticas brasileiras.

\subsubsection{Comprimento total das Pistas de táxi}

\subsubsection{Comprimento total de Sistema Complexo de Pistas de Táxi em aeroportos}

Para o caso de um Sistema Complexo de Pistas de Táxi (SCPTX), adequado para atendimento de aeroportos com demanda concentrada em horários de pico, busca-se estabelecer o comprimento total de tais vias, uma vez que tal sistema é composto por mais de uma via destinada ao trânsito de aeronaves.

Para que isso seja possível, é interessante apresentar a estrutura desse sistema complexo. A Figura 29 apresenta um SCPTX, adequado a aeroportos com demanda concentrada em horários de pico.

Figura 29 - Sistema Complexo de Pistas de Táxi

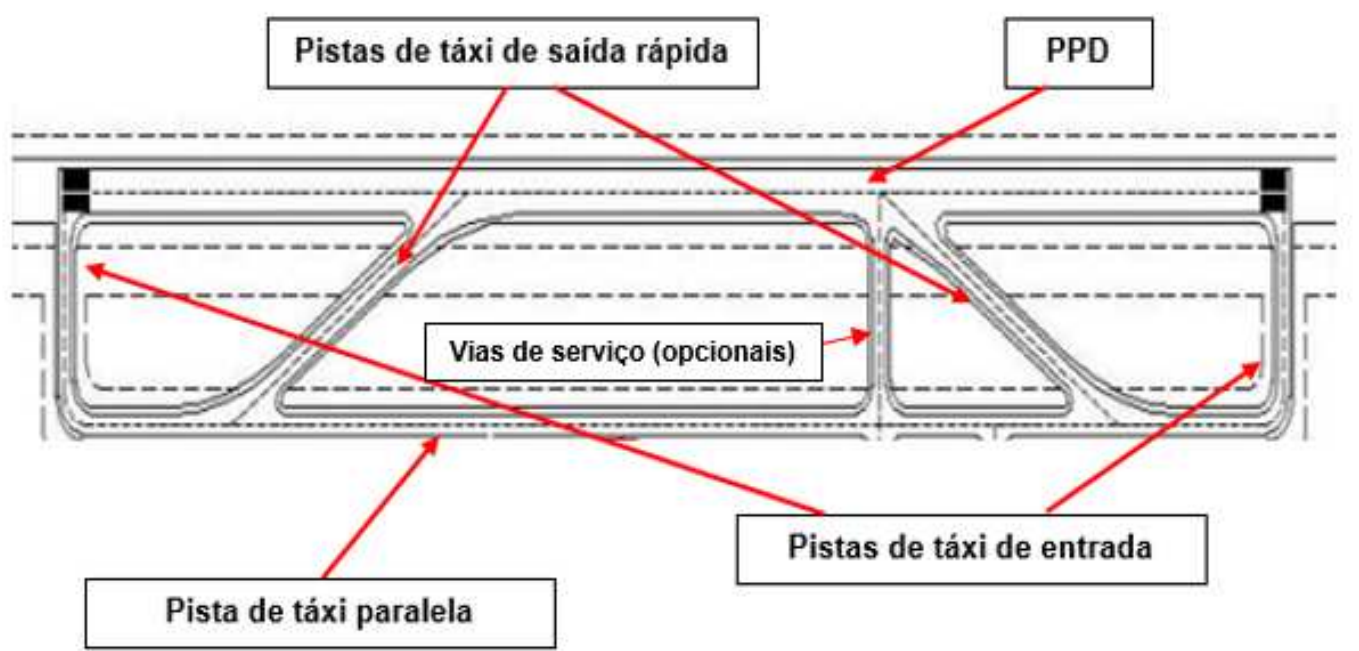

Fonte: Elaboração própria, com base em BRASIL (2015a) - Adaptado 
Para a estimativa do comprimento total das Pistas de táxi, nesse caso, foi considerado que existe uma Pista de táxi paralela a PPD, com mesma extensão, duas Pistas de táxi de saída rápida e duas Pistas de táxi de entrada perpendiculares à PPD.

Na Figura 29 ainda está presente uma via de serviço (para veículos como automóveis e utilitários), que não obrigatoriamente faz parte de um aeroporto. Em aeroportos mais movimentados, pode ser empregada para trânsito de veículos de serviço, fiscalização, manutenção ou apoio à movimentação das aeronaves no solo.

De forma expedida, a Pista de táxi paralela, por ser parametrizável segundo o comprimento da PPD, tem seu comprimento estimado segundo a Equação 6:

$$
L_{\text {PistaTáxi Paralela }}=L_{P P D}(m)
$$

Quanto ao comprimento das Pistas de táxi de saída rápida, é preciso definir a inclinação (no plano das pistas) da mesma em relação à PPD. Seguindo o previsto em ANAC (2018b), esta deve ter seu ângulo de intersecção, com a PPD, não maior que $45^{\circ}$, nem menor que $25^{\circ}$, sendo preferível 30․ Dessa forma, emprega-se o ângulo de $30^{\circ}$ para o modelamento em curso.

Mas, para definição do comprimento desses tramos de via, ainda deve ser seguida a separação mínima entre PPD e a Pista de táxi paralela, como mostrado na Figura 30, onde está indicada por D.

Figura 30 - Detalhes do Sistema Complexo de Pistas de Táxi

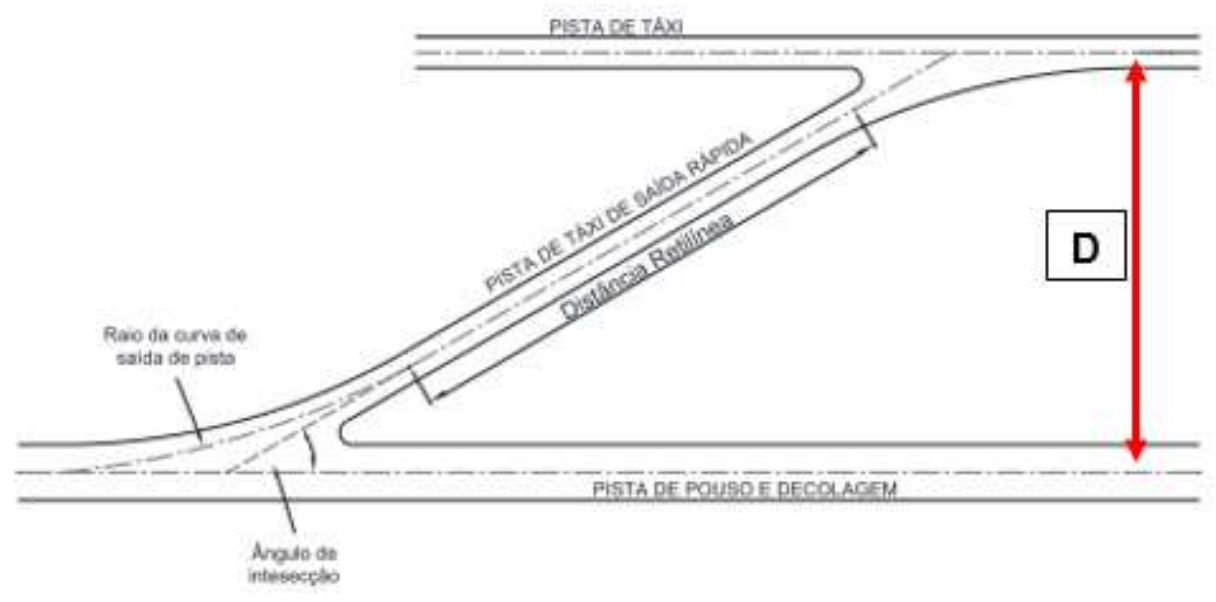

Fonte: ANAC (2018b) - Adaptado 
Para determinação da distância D, a Tabela 8 apresenta as distâncias entre os eixos da PPD e eixo da Pista de táxi paralela, segundo a classificação da PPD e aeronaves que operam no aeroporto.

Ainda segundo ANAC (2018b), existem diferenças entre as distâncias (D) requeridas entre aeroportos que operam sob instrumentos de apoio à navegação aérea de aproximação e os que não possuem tais equipamentos. Para o caso em estudo, considerou-se que o aeroporto é operado por instrumentos. Quanto maiores as aeronaves a serem operadas e o grau de instrumentação requerido, maior será a distância (D).

\begin{tabular}{|c|c|c|c|c|}
\hline \multirow{2}{*}{$\begin{array}{c}\text { Grupo } \\
\text { geométrico }\end{array}$} & \multicolumn{4}{|c|}{ Grupo da aeronave } \\
\hline & 1 & 2 & 3 & 4 \\
\hline$A$ & 77,5 & 77,5 & - & - \\
\hline $\mathrm{B}$ & 82 & 82 & 152 & - \\
\hline $\mathrm{C}$ & 88 & 88 & 158 & 158 \\
\hline $\mathrm{D}$ & - & - & 166 & 166 \\
\hline$E$ & - & - & 172,5 & 172,5 \\
\hline $\mathrm{F}$ & - & - & 180 & 180 \\
\hline
\end{tabular}

Fonte: ANAC (2018b) - Adaptado

Para o caso de um aeroporto doméstico brasileiro, seguindo a modelagem desse trabalho, como anteriormente apresentado na seção 5.2.2, as PPD devem atender as aeronaves classificadas sob o código 4C, logo, a distância D tem valor mínimo de 158 m (vide Tabela 8); medida fixada para todas as modelagens de Sistemas de Pistas de táxi deste trabalho.

Assim, o comprimento das duas Pistas de táxi de saída rápida a serem provisionadas na modelagem é obtido segundo a Equação 7:

$$
L_{\text {PistaTáxi rápidas }}=2 \times \frac{158}{\operatorname{sen} 30^{\circ}}=632 \mathrm{~m}
$$

As Pistas de táxi de entrada, que são perpendiculares em número de duas, têm seu comprimento estimado como sendo a distância D, dessa forma, a Equação 8 indica o comprimento dessa parte do sistema complexo das Pistas de Táxi. 


$$
L_{\text {PistaTáxi entrada }}=2 \times 158=316 m
$$

Por fim, a Equação 9 indica o comprimento total de um sistema complexo de Pistas de táxi para atendimento de aeroportos com demanda concentrada em horários de pico:

$$
\begin{gathered}
L_{S C P T X}=L_{\text {PistaTáxi Paralela }}+L_{\text {PistaTáxi rápidas }}+L_{\text {PistaTáxi entrada }} \\
L_{S C P T X}=L_{P P D}+632+316 \quad(\mathrm{~m})
\end{gathered}
$$

\subsubsection{Comprimento total do Sistema Simples de Pista de Táxi em aeroportos}

No caso de aeroporto com desconcentrada demanda ao longo dia, ou seja, as operações ocorrem distribuídas ao longo de todo o dia, sem caracterização de horários de pico para atendimento da demanda (a ponto de não existir formação de filas de aeronaves para decolagem ou pouso), pode-se empregar um Sistema Simples de Pista de Táxi (SSPTX).

O aeródromo pode contar, nesses casos, com única Pista de táxi, ligando a Pista de pouso e decolagem (PPD) ao Pátio de estacionamento de aeronaves (PEA).

Para esse trabalho, formatou-se, para o SSPTX, única Pista de táxi de entrada, perpendicular à PPD, com comprimento estimado como sendo a distância $D$ (vide Figura 30). O comprimento dessa pista é definido como: $L_{S S P T X}=158(\mathrm{~m})$.

\subsubsection{Largura das Pistas de táxi}

Para definição da largura das Pistas de táxi (PTX) de um aeroporto, levam-se em consideração, novamente, as características da aeronave de projeto.

Nesse caso, seguindo ANAC (2018b), para o enquadramento da aeronave de projeto, cuja classificação, como anteriormente explanado na seção 5.2.2, é 4C; a largura 
mínima requerida para as PTX, é $25 \mathrm{~m}$, valor fixado para todas as modelagens desenvolvidas.

\subsection{5. Área do Pátio de estacionamento de aeronaves}

Existem definições sobre o dimensionamento necessário de área para o Pátio de estacionamento de aeronaves (PEA). No entanto, esse estudo, como já frisado, não busca determinar métodos de dimensionamento de instalações aeroportuárias, mas sim formas de se estimarem os parâmetros físicos que interferem nos custos de construção dos elementos trabalhados.

Um PEA deve ter sua área dimensionada para atendimento de número de aeronaves que comporte a demanda de passageiros ou cargas, além de contar com posições de estacionamento de aeronaves para longas estadias, serviços de manutenção ocasionais ou operações de carregamento ou descarregamento de cargas, nos casos de aeroportos com terminais de carga.

O empreendedor, nas fases preliminares de estudos de viabilidade, dificilmente conseguira definir esses parâmetros com precisão. Utilizando os dados relativos à caracterização dos aeroportos apresentados no Capítulo 4, parametrizou-se a área destinada ao PEA frente a demanda atendida no aeroporto.

O Gráfico 2 apresenta a correlação entre a demanda e área destinada ao PEA, considerando todos os aeroportos caracterizados.

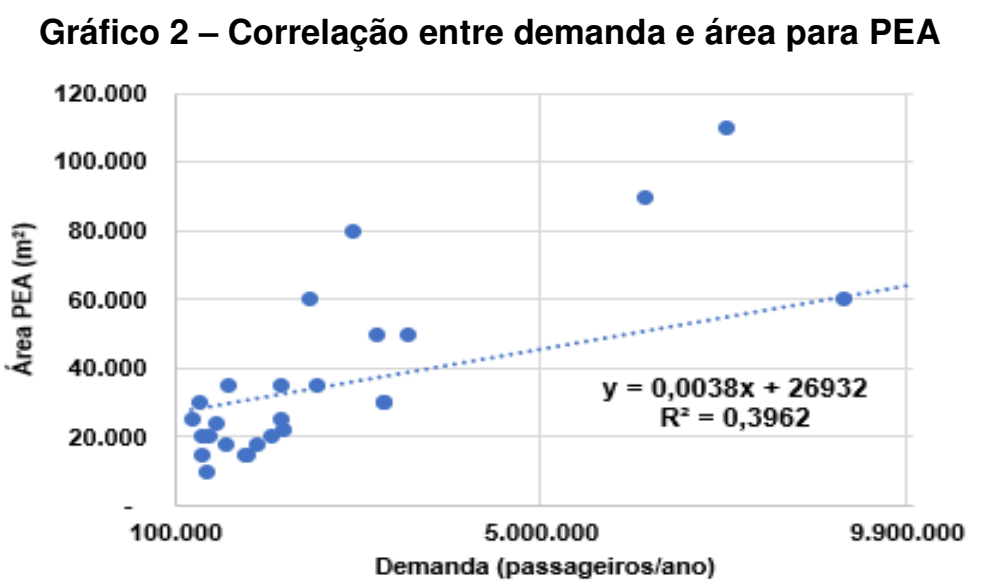

Fonte: Elaboração própria, com base em INFRAERO (2019) 
Ainda que a equação de regressão mostrada no Gráfico 2 não apresente $\mathrm{R}^{2}$ elevado, trata-se da melhor forma encontrada para geração de uma correlação simples entre a demanda e a área de um PEA. Vale ressaltar que foram testadas outras regressões, com outros formatos, como exponencial e logarítmico; no entanto, esses formatos forneceram correlação inferior ao modelo linear apresentado e adotado.

Dessa forma, variando-se a demanda, como fator paramétrico, a Equação 10, obtida da curva de tendência do Gráfico 2, permite determinação do parâmetro físico buscado - Área do PEA (APEA).

$$
A_{P E A}=0,0038 \times \text { Demanda }_{\text {Aerop. }}+26.932\left(\mathrm{~m}^{2}\right)
$$

\subsubsection{Estrutura da pavimentação}

Para a modelagem física da estrutura das superfícies pavimentadas, seja com pavimento flexível ou rígido, leva-se em consideração: composição do tráfego (composto pela operação de modelos específicos de aeronaves ou um conjunto de aeronaves), quantidade de operações de aeronaves (pousos e decolagens) e capacidade de suporte do subleito (DURAN, 2015).

Esses fatores, acrescidos das informações sobre o horizonte de vida útil do projeto e a taxa de crescimento do mercado de aviação civil em questão, permitem modelar a estrutura dos pavimentos aeroportuários (determinação das espessuras das camadas).

Como não existem e não seria viável a construção de aeroportos comerciais destinados exclusivamente a um único modelo de aeronave, seguindo o preconizado pela literatura especializada, deve-se compor um conjunto de aeronaves a serem operadas em determinada localidade, conforme adiante apresentado.

Para dimensionamento e obtenção das estimativas de espessuras das camadas do pavimento aeroportuário, foi empregado um software de projeto de pavimentos aeroportuários, validado e amplamente empregado em projetos de construção e 
reforma de Pistas de pouso e decolagem (PPD), Pistas de táxi (PTX) e Pátios de estacionamento de aeronaves (PEA) em aeroportos nos Estados Unidos da América.

Este software também tem larga utilização em diversos países, entre eles o Brasil. Outros métodos também são aplicáveis, como ábacos fornecidos por autoridades de aviação civil, fabricantes e pesquisadores da área. O mesmo foi empregado para os modelo desenvolvido nesse estudo.

Trata-se do software FAARFIELD v 1.42, desenvolvido sob demanda e validado pela Federal Aviation Administration, agência reguladora do setor da aviação civil norteamericano, análoga à Agência Nacional de Aviação Civil no Brasil.

Emprega como dados, para determinação das espessuras das camadas de pavimentos aeroportuários, o tipo de solo, demanda e aeronaves que se utilizarão da infraestrutura a ser executada, horizonte de vida útil da pista e projeção de crescimento das operações.

O uso do software FAARFIELD é indicado no normativo norte-americano AC 1505320-6F (FAA, 2016) - que aborda o projeto do pavimento aeroportuário e AC 1505370-10G (FAA, 2014) - que aborda os materiais e especificações do pavimento aeroportuário. Tal software, emprega, para dimensionamento da estrutura dos pavimentos aeroportuários, elementos finitos tridimensionais, de forma a otimizar a determinação das espessuras das camadas do pavimento aeroportuário.

Seguindo os tutoriais e instruções de agentes da Federal Aviation Administration, consolidaram-se 18 modelagens de estrutura de pavimento, visando varrer as possibilidades e permitindo a parametrização entre espessuras das camadas frente à demanda a ser atendida.

Quanto ao uso do software, como dado de entrada, primeiramente é indicado o "nome" de cada modelo. Após isto, é definido o tipo de revestimento do pavimento a ser aplicado - rígido (placas de concreto) ou flexível (asfáltico).

Se rígido, entra-se com o dado de Coeficiente de recalque (k). Se flexível, entra-se com o CBR, seguindo as exposições já apresentadas nesse trabalho. 
Estabelece-se o conjunto de aeronaves empregadas, no caso composto pelas aeronaves modelos B737-800, A320-200 e E195. No entanto, para dimensionamento das camadas dos pavimentos, é também necessário conhecer a quantidade de decolagens anuais de cada modelo de aeronave que compõem o conjunto, bem como o crescimento da demanda para o horizonte de projeto considerado.

Para estabelecimento da quantidade de movimentos (decolagens e pousos) para cada modelagem, consideraram-se demandas entre 1.000 .000 a 10.000 .000 de passageiros anuais. Para traduzir o número de passageiros em quantidade de movimentos de aeronaves (número de decolagens), emprega-se o dado referentes à quantidade de passageiros que cada aeronave transporta.

\subsubsection{Composição do tráfego aéreo}

A Tabela 9 apresenta os modelos de aeronaves considerados e a participação de cada modelo nas operações domésticas brasileiras. Os valores indicados levam em consideração a participação de mercado de cada companhia aérea e também a composição de suas respectivas frotas, como o descrito na Seção 4.2.

Tabela 9 - Modelos de aeronaves e participação nas operações aéreas domésticas

\begin{tabular}{cc}
\hline $\begin{array}{c}\text { Aeronave } \\
\text { modelo }\end{array}$ & $\begin{array}{c}\text { Participação das } \\
\text { operações }\end{array}$ \\
\hline B737-800 & $45 \%$ \\
\hline A320-200 & $45 \%$ \\
\hline E195 & $10 \%$ \\
\hline
\end{tabular}

Fonte: Elaboração própria

\subsubsection{Demanda e quantidade de decolagens}

Outro fator fundamental para dimensionamento da estrutura de um pavimento é a determinação da demanda, que, frente à ocupação efetiva das aeronaves, determina a quantidade de decolagens realizadas por ano por modelo de aeronave. 
A Tabela 10 apresenta, para o conjunto de modelos de aeronaves considerado, a quantidade total de assentos de cada modelo e os assentos considerados "ocupados", segundo a taxa de ocupação média desses assentos.

Tabela 10 - Ocupação dos assentos

\begin{tabular}{|c|c|c|c|}
\hline $\begin{array}{l}\text { Aeronave } \\
\text { modelo }\end{array}$ & $\begin{array}{l}\text { Assentos } \\
\text { Totais }\end{array}$ & $\begin{array}{l}\text { Ocupação } \\
\text { considerada }\end{array}$ & $\begin{array}{l}\text { Assentos } \\
\text { ocupados }\end{array}$ \\
\hline B737-800 & 184 & & 150 \\
\hline A320-200 & 180 & $81,3 \%$ & 146 \\
\hline E195 & 118 & & 96 \\
\hline
\end{tabular}

Fonte: Elaboração própria, com base em ANAC (2018c)

No entanto, para os dados de entrada no software empregado para dimensionamento da estrutura da pavimentação, é necessário conhecer a quantidade de decolagens de cada modelo de aeronave que compõem o conjunto delimitado.

Assim, a Tabela 11 apresenta, para as demandas de 1.000.000, 5.000.000 e 10.000.000 de passageiros/ano, as quantidades de decolagens diárias e anuais, considerando composição do tráfego dos diferentes modelos de aeronaves e taxa de ocupação média considerada dos assentos.

Considerou-se que a quantidade de passageiros que embarcam (decolam) é igual à quantidade de passageiros que desembarcam (pousam), ou seja, aproximadamente $50 \%$ embarcam e $50 \%$ desembarcam. A demanda indicada, apresenta o total de passageiros, que embarcam e desembarcam.

Tabela 11 - Decolagens anuais para cada modelo de aeronave

\begin{tabular}{cccc}
\hline $\begin{array}{c}\text { Demanda } \\
\text { (passageiros/ano) }\end{array}$ & $\begin{array}{c}\text { Aeronave } \\
\text { modelo }\end{array}$ & Decolagens diárias & $\begin{array}{c}\text { Decolagens } \\
\text { anuais }\end{array}$ \\
\hline \multirow{2}{*}{1.000 .000} & $\mathrm{~B} 737-800$ & 5 & 1.825 \\
\cline { 2 - 4 } & $\mathrm{A} 320-200$ & 5 & 1.825 \\
\hline \multirow{2}{*}{5.000 .000} & $\mathrm{E} 195$ & 2 & 730 \\
\cline { 2 - 4 } & $\mathrm{B} 737-800$ & 21 & 7.665 \\
\hline \multirow{2}{*}{10.000 .000} & $\mathrm{~A} 320-200$ & 22 & 8.030 \\
\cline { 2 - 4 } & $\mathrm{E} 195$ & 8 & 2.920 \\
\cline { 2 - 4 } & $\mathrm{A} 320-200$ & 42 & 15.330 \\
\hline & $\mathrm{E} 195$ & 43 & 5.695 \\
\hline
\end{tabular}

Fonte: Elaboração própria 
Como observação referente às tabelas apresentadas, a quantidade de aeronaves decolando por dia teve seus valores arredondados para cima, uma vez que não teria sentido fracionamento da quantidade de movimentos de aeronaves.

O software empregado ainda prevê que as operações têm horizonte de crescimento ao longo do horizonte da vida útil do projeto.

Relembrando, a taxa de crescimento do mercado de aviação doméstica aplicada neste trabalho foi de $3,35 \%$ ao ano.

A vida útil do projeto também deve ser indicada, visto influenciar principalmente na camada de revestimento do pavimento. Com base nas experiências nacionais e entrevistas com especialistas do setor, considerar uma vida útil do projeto de 20 anos é bastante adequado.

Com essas informações de entrada no software, após o processamento computacional, obteve-se a estrutura do pavimento para cada modelo proposto (resultado - saída).

Como exemplo, a Figura 31 apresenta as espessuras e camadas para o pavimento modelado, onde se considerou demanda a ser atendida de 1.000 .000 de passageiros ao ano, pavimentação flexível, subleito com $\mathrm{CBR}=3 \%$. O resultado completo de todas as modelagens está no Apêndice B.

\section{Figura 31 - Exemplo de extrato da modelagem para pavimento aeroportuário}

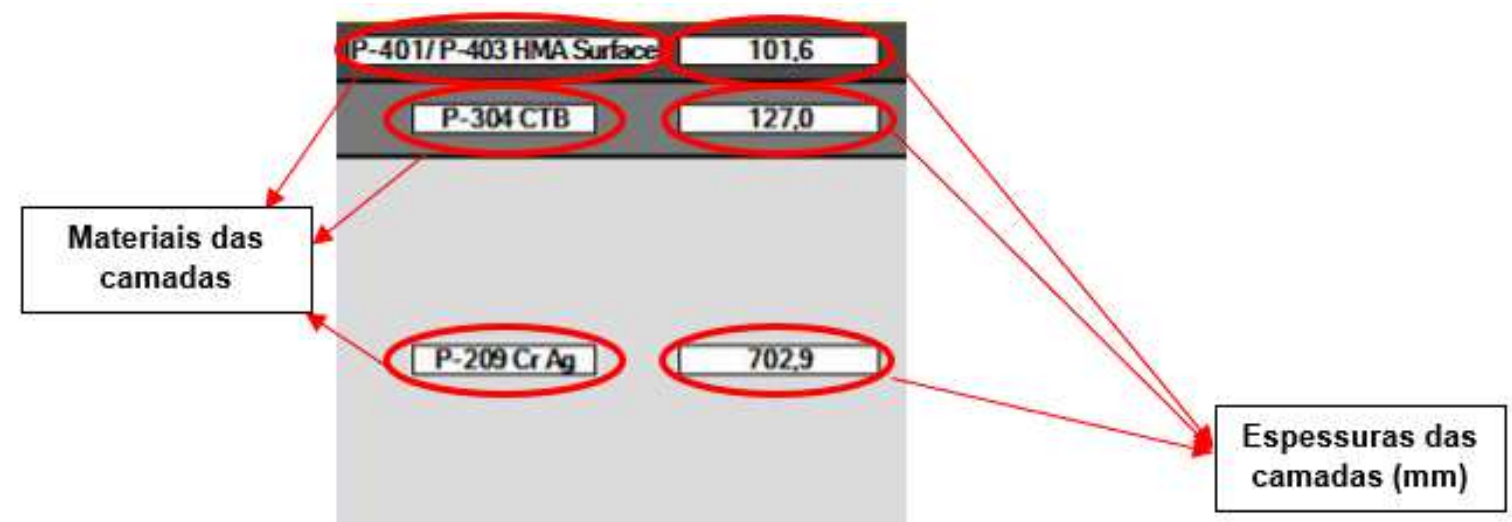

Solo original (subleito)

Fonte: Software FAARFIELD v 1.42 - Adaptado 
Para melhor entendimento do exposto na Figura 32, têm-se, nesse caso, que, para um subleito (solo original) com CBR $=3 \%$, a sub-base (composta pelo material P-209 $\mathrm{Cr}$ Ag) apresenta espessura de 702,9 mm, a base (composta pelo material P-304 CTB) apresenta espessura de 127,0 mm e o revestimento asfáltico (P-401 / P-403 HMA Surface) apresenta espessura de 101,6 mm.

A denominação dos materiais seguiu os padrões norte-americanos, preconizados em FAA (2014), uma vez que o software empregado foi desenvolvido empregando como drivers (dados de entrada) especificações técnicas dos materiais de construção daquele país. Mas, como adaptação ao cenário nacional, após análise das especificações de cada material anteriormente codificado, pode-se dizer que:

- Material da sub-base (P-209 Cr Ag) seria um agregado granular para emprego na construção civil em camadas inferiores sobre o subleito, que atenda às especificações apresentadas na Tabela 12.

Tabela 12 - Especificações do agregado considerado para sub-base

\begin{tabular}{ccc}
\hline $\begin{array}{c}\text { Granulometria - } \\
\text { Peneira (mm) }\end{array}$ & $\begin{array}{c}\text { Faixa de pesagem por } \\
\text { porcentagem }\end{array}$ & $\begin{array}{c}\text { Tolerância na } \\
\text { Graduação Final (\%) }\end{array}$ \\
\hline 50 & 100 & 0 \\
\hline 38 & $95-100$ & \pm 5 \\
\hline 25 & $70-95$ & \pm 8 \\
\hline 19 & $55-85$ & \pm 8 \\
\hline 4,75 & $30-60$ & \pm 8 \\
\hline 0,75 & $10-30$ & \pm 5 \\
\hline 0,075 & $0-8$ & \pm 3 \\
\hline
\end{tabular}

Fonte: FAA (2014)

- Material da base (P-304 CTB) seria um agregado granular tratado com cimento Portland. Os materiais são uniformemente misturados com adição de água; posteriormente são espalhados mecanicamente sobre a sub-base e compactado com rolos, seguindo especificações do projeto. O agregado deve atender às especificações apresentadas na Tabela 13. 
Tabela 13 - Especificações do agregado considerado para base

\begin{tabular}{cc}
\hline $\begin{array}{c}\text { Granulometria - } \\
\text { Peneira }\end{array}$ & $\begin{array}{c}\text { Faixa de pesagem por } \\
\text { porcentagem }\end{array}$ \\
\hline $50 \mathrm{~mm}$ & 100 \\
\hline $4,75 \mathrm{~mm}$ & $45-100$ \\
\hline $1,80 \mathrm{~mm}$ & $37-80$ \\
\hline $450 \mu \mathrm{m}$ & $15-50$ \\
\hline $210 \mu \mathrm{m}$ & $0-25$ \\
\hline
\end{tabular}

Fonte: FAA (2014)

- Material do revestimento asfáltico (P-401 / P-403 HMA Surface) seria o equivalente ao asfalto usinado a quente.

\subsubsection{Espessuras das camadas da pavimentação}

Nessa seção são apresentadas as espessuras que compõem a estrutura de cada modelagem, com a variação da capacidade de suporte do subleito e demanda a ser atendida. $\mathrm{O}$ detalhamento completo está no Apêndice $\mathrm{B}$.

A Tabela 14 apresenta, sinteticamente, os dados obtidos através das simulações inseridas no software FAIRFIELD, para pavimentos flexíveis.

Tabela 14 - Espessura total para pavimentação flexível frente à demanda (m)

\begin{tabular}{cccc}
\hline $\begin{array}{c}\text { Demanda } \\
\text { (passageiros/ano) }\end{array}$ & CBR = 3\% & CBR = 10\% & CBR = 15\% \\
\hline 1.000 .000 & 0,93 & 0,52 & 0,39 \\
\hline 5.000 .000 & 0,96 & 0,55 & 0,42 \\
\hline 10.000 .000 & 0,97 & 0,56 & 0,43 \\
\hline
\end{tabular}

Fonte: Elaboração própria, com base no Software FAIRFIELD v 1.42

A Tabela 15 apresenta, sinteticamente, os dados obtidos através das simulações inseridas no software FAIRFIELD, para pavimentos rígidos. 
Tabela 15 - Espessura total para pavimentação rígida frente à demanda (m)

\begin{tabular}{cccc}
\hline $\begin{array}{c}\text { Demanda } \\
\text { (passageiros/ano) }\end{array}$ & $\mathbf{k}=\mathbf{2 0}\left(\mathbf{M N} / \mathbf{m}^{\mathbf{3}}\right)$ & $\mathbf{k}=\mathbf{8 0}\left(\mathbf{M N} / \mathbf{m}^{\mathbf{3}}\right)$ & $\mathbf{k}=\mathbf{1 5 0}\left(\mathbf{M N} / \mathbf{m}^{\mathbf{3}}\right)$ \\
\hline 1.000 .000 & 0,67 & 0,66 & 0,67 \\
\hline 5.000 .000 & 0,68 & 0,68 & 0,68 \\
\hline 10.000 .000 & 0,69 & 0,68 & 0,69 \\
\hline
\end{tabular}

Fonte: Elaboração própria, com base no Software FAIRFIELD v 1.42

Como forma a melhorar a análise das informações, verificou-se que para a pavimentação rígida, não foram obtidas variações significativas das espessuras, qualquer que seja o parâmetro analisado (demanda ou capacidade de suporte do solo), o que leva à consideração de uma espessura média representativa, considerada adequada para as estimativas de custos desenvolvidas. Constata-se que a espessura média total, para pavimentação rígida, nas condições desse trabalho, é 0,68 m.

Os resultados obtidos para as espessuras para pavimentação aeroportuária enquadram-se nos parâmetros da literatura especializada, que indica que as espessuras típicas dos pavimentos aeroportuários vão de $0,15 \mathrm{~m}$, para operação de pequenas aeronaves privadas, até aproximadamente $0,90 \mathrm{~m}$ a 1,00 m, para operação de aeronaves médias e de grande porte, considerando também o tipo de solo do subleito (YOUNG; WELLS, 2014).

O Gráfico 3 apresenta curva com a correlação entre capacidade de suporte do subleito (CBR) e espessura total da estrutura para pavimentação flexível.

\section{Gráfico 3 - Correlação entre CBR do subleito e espessura da pavimentação flexível}

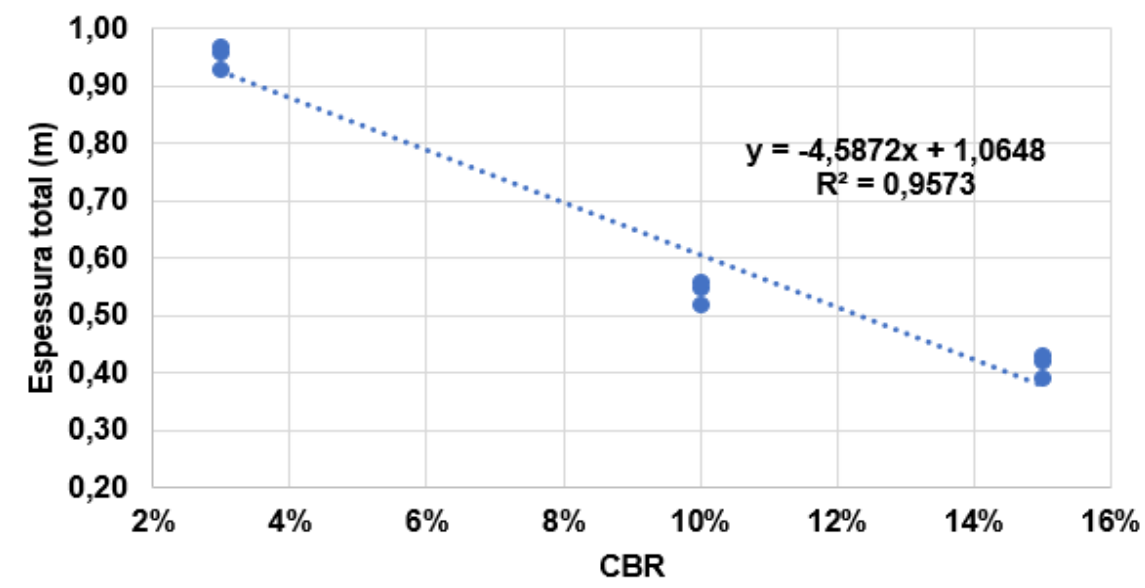

Fonte: Elaboração própria, com base em INFRAERO (2019) 
A partir da análise do Gráfico 3, atesta-se correlação significativa entre o CBR e variação da espessura total da pavimentação flexível. Variando-se a capacidade de suporte do subleito, como fator paramétrico, a Equação 11, obtida através da regressão linear presente no Gráfico 3, permite determinação do parâmetro físico Espessura total da pavimentação flexível (Esppav.Flex).

$$
\text { Esp.Pav.Flex. }_{\text {. }}=-4,5872 \times\left(\frac{C B R(\%)}{100}\right)+1,0648(m)
$$

\subsection{CUSTOS UNITÁRIOS PARA APLICAÇÃO NO MODELAMENTO}

Para composição das estimativas dos custos de construção, informações sobre os materiais e serviços envolvidos são necessárias.

Para isso foram eleitos, como base para o levantamento, os itens previstos nas tabelas do Sistema Nacional de Pesquisa de Custos e Índices da Construção Civil (SINAPI, 2015a), correlacionando com os itens presentes e necessários para execução dos pavimentos aeroportuários. Esses itens são apresentados na Tabela 16.

Nesse Sistema apresentam-se itens com as características mais aplicáveis às obras a serem realizadas no Brasil, sendo que na Tabela 16 são apresentados também os custos para esses itens considerados na composição do modelo proposto.

Esses custos estão expressos em unidade monetária por quantidade de serviço, no caso, Reais por quantidade de serviço (R\$/QS). A unidade física de mensuração é apresentada na última coluna. 
Tabela 16 - Custos considerados para itens empregados na composição do modelo proposto

\begin{tabular}{|c|c|c|c|c|}
\hline$\#$ & Item & Observação & $\begin{array}{c}\text { Custo } \\
\text { (R\$/QS) }\end{array}$ & Unidade \\
\hline 1 & Limpeza do solo original & - & 0,51 & $m^{2}$ \\
\hline 2 & Escavação de solo inadequado & - & 1,90 & $\mathrm{~m}^{3}$ \\
\hline 3 & Transporte de material removido & - & 35,11 & $\mathrm{~m}^{3}$ \\
\hline 4 & Revestimento - Placas de concreto & \multirow{4}{*}{$\begin{array}{l}\text { Pavimento } \\
\text { Rígido }\end{array}$} & 307,51 & $\mathrm{~m}^{3}$ \\
\hline 5 & Armadura de ligação & & 6,05 & $\mathrm{~kg}$ \\
\hline 6 & Base & & 127,69 & $\mathrm{~m}^{3}$ \\
\hline 7 & Sub-base & & 66,69 & $\mathrm{~m}^{3}$ \\
\hline 8 & Revestimento - Asfalto & \multirow{3}{*}{$\begin{array}{l}\text { Pavimento } \\
\text { Flexível }\end{array}$} & 634,52 & $\mathrm{~m}^{3}$ \\
\hline 9 & Base & & 127,69 & $\mathrm{~m}^{3}$ \\
\hline 10 & Sub-base & & 66,69 & $\mathrm{~m}^{3}$ \\
\hline 11 & Locação da obra / Topografia & - & 17,34 & $\mathrm{~m}^{2}$ \\
\hline 12 & Tratamentos finais no pavimento e sinalização & - & 27,73 & $m^{2}$ \\
\hline 13 & Limpeza de final de obra & - & 2,88 & $m^{2}$ \\
\hline
\end{tabular}

Fonte: SINAPI (jul/2018)

As informações do SINAPI são geradas e apresentadas para cada estado brasileiro. Como nesta dissertação busca-se um modelo que seja representativo para estimar custos em todo o país, por simplificação e por serem adaptados a modelagens de custos de obras aeroportuárias para todo o território, referem-se a uma média nacional dos valores citados no SINAPI.

As unidades de mensuração variam de serviço para serviço (SOUZA, 2006). Assim, o serviço de limpeza do solo é mensurado em área, enquanto escavação do solo inadequado em volume e assim por diante para os demais itens.

Para melhor detalhamento dos itens levantados na Tabela 16, o Anexo A apresenta descrições mais completas das informações do SINAPI, para os itens listados. Toda a metodologia empregada nas composições segue o estabelecido em SINAPI (2015b).

Em caso de replicação para casos reais, pode-se optar pelo uso desses custos atualizados ou, ainda, emprego de valores mais adequados ao empreendedor quando estiver na fase de avaliação preliminar sobre a viabilidade. 
Essas estimativas podem ser obtidas de registros históricos de custos mais afetos ao empreendedor, em outras plataformas de custos ou, ainda, orçamentos obtidos diretamente com fornecedores.

Notar que se pretende, com esse estudo, estabelecer método mais expedito, visto que se trata de buscar informações para balizar decisões ainda em fases preliminares, o que acaba inviabilizando alocação de investimento e tempo maiores na busca de dados mais acurados.

\subsubsection{Levantamento das quantidades de materiais e serviços para construção de superfícies pavimentadas para operações de aeronaves em aeroportos}

Para cada modelo paramétrico estabelecido, foram obtidas as quantidades necessárias dos materiais e serviços para execução de uma unidade $\left(1 \mathrm{~m}^{2}\right)$ de Pista de pouso e decolagem, Pista de táxi (taxiways) ou Pátio de estacionamento de aeronaves. Os itens considerados foram:

- Limpeza do solo original: considerada a área a ser pavimentada, acrescida de $20 \%$ (arredores), como sendo a região onde é necessária a limpeza, que compreende a retirada de objetos, detritos e camada vegetal.

- Escavação de solo inadequado para execução do pavimento: considerada a área a ser pavimentada. A profundidade da escavação varia conforme a estrutura do pavimento (espessuras das camadas).

Foi considerado que o terreno é plano e a cota final (arrasamento) com o pavimento pronto, será a cota original do terreno antes de qualquer movimentação de terra, excluindo a camada vegetal. Portanto o volume a ser escavado será variável em função da estrutura obtida para o pavimento. Essa ideia baseia-se no fato que o terreno ao redor das pistas de aeroportos deve ser nivelado e trata-se de uma premissa adequada para aplicação expedita do modelo desenvolvido.

- Transporte de material removido (camada vegetal e do solo mole escavado): considerando a camada vegetal superficial com $15 \mathrm{~cm}$ de espessura e o volume 
de solo escavado, adicionando empolamento de $30 \%$, chegou-se ao volume total a ser transportado. Considerou-se, para efeitos desse trabalho, uma Distância Média de Transporte (DMT) de 29,5 km.

Essa DMT foi estabelecida considerando o valor médio, dentre as medidas para transporte de material, de dois projetos de construção bastante representativos para aeroportos brasileiros. O primeiro projeto apresentou DMT de $20 \mathrm{~km}$ - projeto que embasou a concorrência para construção do aeroporto de Confins (SEIL/PR, 2014). O segundo projeto apresentou DMT de $39 \mathrm{~km}$ referente à construção do novo aeroporto de Florianópolis (TCU, 2014).

Ainda sobre a DMT, esta medida pode variar muito de um empreendimento para outro, mas, para não se deixar de indicar um número para fins do raciocínio sendo desenvolvido, o autor escolheu os dois projetos supracitados - relevantes dentro do banco de dados disponível - tais valores foram empregados nesse estudo.

- Pavimento: conforme apresentado no Capítulo 2, sua estrutura é composta por camadas e pode apresentar revestimento rígido ou flexível. Como foi empregado o software da FAA e os materiais descritos em FAA (2014), os modelos apresentam as camadas seguindo as especificações normalizadas daquele país; no entanto, equivalentes para o cenário brasileiro são indicados na sequência:

a. Revestimento: P-401/P-403 Hot Mix Asphalt (HMA) Pavements (pavimento flexível) ou PCC Surface (pavimento rígido). Equivalente no Brasil: mistura asfáltica a quente (pavimento flexível) ou placas rígidas de concreto (pavimento rígido);

b. Base: P-304 Cement-Treated Base Course. Equivalente no Brasil: base tratada com cimento;

c. Sub-base: P-209 Crushed Aggregate Base Course. Equivalente no Brasil: sub-base tratada com agregado (brita graduada);

d. Subleito: solo original com o CBR especificado ou coeficiente de recalque (k) especificado; 
e. À camada de revestimento (placas rígidas de concreto) acrescentam-se as armaduras e barras de ligação entre as placas de concreto que compõem a camada de revestimento de concreto. Utilizando métricas referenciadas na literatura, uma taxa de $30 \mathrm{~kg}$ de aço por $\mathrm{m}^{3}$ de concreto é adequada. Nessa taxa está incluído todo o aço necessário (armaduras estruturais e barras de ligação).

- Locação da obra / Topografia: considerados serviços na área a receber pavimento estrutural na pista.

- Tratamentos finais do pavimento e sinalização: considerados serviços na área a receber pavimento estrutural na pista.

- Limpeza final da obra: considerados serviços na área a receber pavimento estrutural na pista.

O Apêndice $C$ apresenta as quantidades requeridas para execução de uma unidade de cada estrutura de pavimento considerada na modelagem.

\subsubsection{Estimativas dos custos para aplicação nas modelagens}

Através de tabulações e composições, pode ser obtida a estimativa de custo para a construção de cada unidade de cada estrutura de pavimento considerada na modelagem.

A Tabela 17 apresenta esses custos unitários. Para os pavimentos com revestimento flexível, na capacidade de suporte do subleito, o valor indicado representa o CBR (\%). Para os pavimentos com revestimento rígido, indica-se o coeficiente de recalque $-k$ $\left(\mathrm{MN} / \mathrm{m}^{3}\right)$. 
Tabela 17 - Custos unitários estimados para pavimento aeroportuário

\begin{tabular}{|c|c|c|c|c|}
\hline$\#$ & $\begin{array}{l}\text { Tipo de } \\
\text { revestimento }\end{array}$ & $\begin{array}{l}\text { Capacidade } \\
\text { de suporte } \\
\text { do subleito }\end{array}$ & $\begin{array}{c}\text { Demanda } \\
\text { (passageiros/ano) }\end{array}$ & $\begin{array}{l}\text { Custo estimado para } \\
\text { construção }\left(\mathrm{R} \$ / \mathrm{m}^{2}\right)\end{array}$ \\
\hline 1 & \multirow{9}{*}{ Flexível } & \multirow{3}{*}{3} & 1.000 .000 & 227,38 \\
\hline 2 & & & 5.000 .000 & 230,49 \\
\hline 3 & & & 10.000 .000 & 231,73 \\
\hline 4 & & \multirow{3}{*}{10} & 1.000 .000 & 180,59 \\
\hline 5 & & & 5.000 .000 & 184,15 \\
\hline 6 & & & 10.000 .000 & 185,58 \\
\hline 7 & & \multirow{3}{*}{15} & 1.000 .000 & 166,86 \\
\hline 8 & & & 5.000 .000 & 169,80 \\
\hline 9 & & & 10.000 .000 & 170,98 \\
\hline 10 & \multirow{9}{*}{ Rígido } & \multirow{3}{*}{20} & 1.000 .000 & 304,20 \\
\hline 11 & & & 5.000 .000 & 312,81 \\
\hline 12 & & & 10.000 .000 & 316,71 \\
\hline 13 & & \multirow{3}{*}{80} & 1.000 .000 & 300,03 \\
\hline 14 & & & 5.000 .000 & 308,05 \\
\hline 15 & & & 10.000 .000 & 311,90 \\
\hline 16 & & \multirow{3}{*}{150} & 1.000 .000 & 304,31 \\
\hline 17 & & & 5.000 .000 & 311,58 \\
\hline 18 & & & 10.000 .000 & 315,34 \\
\hline
\end{tabular}

Fonte: Elaboração própria, com base no software FAIRFIELD v 1.42 e SINAPI (jul/2018)

Considerando o anteriormente exposto, os custos apresentam variação significativa para o pavimento flexível frente à capacidade de suporte do CBR; dessa forma, considerando as informações da Tabela 17, através do Gráfico 4, correlacionou-se a espessura total da pavimentação flexível com o custo unitário para produção desse pavimento.

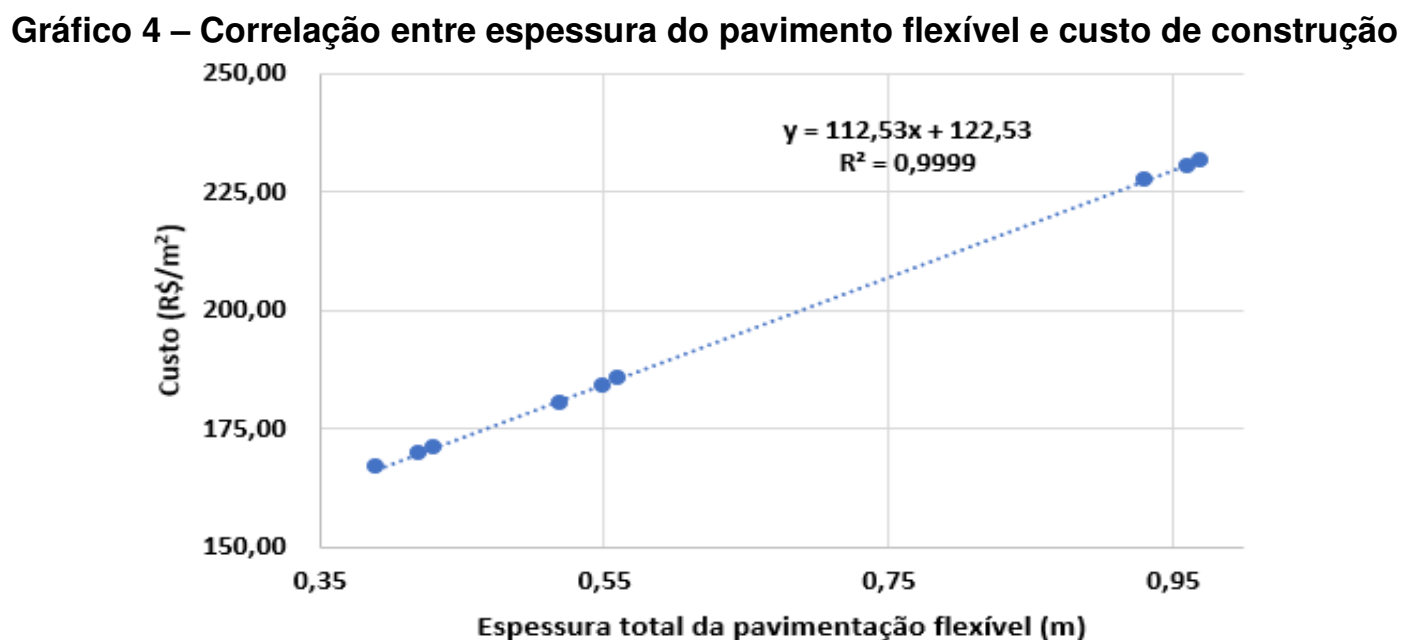

Fonte: Elaboração própria 
Dessa forma, variando-se a espessura total do pavimento, obtida através da parametrização física, a Equação $12{ }^{\left({ }^{9}\right)}$, obtida através da regressão linear da curva de tendência do Gráfico 4, permite determinação do custo estimado unitário para pavimentação flexível (Custopav.Flex.).

$$
\text { Custo }_{\text {Pav.Flex. }}=112,53 x \text { Esp.Pav.Flex. }_{\text {. }}+122,53\left(R \$ / m^{2}\right)
$$

Para o caso da pavimentação rígida, devido à variação de custo menor, frente a todas as parametrizações efetuadas e apresentadas, determina-se um custo estimado fixado, como sendo a média dos valores para pavimentação rígida presentes na Tabela 17, no caso: Custo Médio $o_{\text {Pav.Ríg. }}=309,44\left(R \$ / \mathrm{m}^{2}\right)$.

\subsection{MODELO PARAMÉTRICO PARA ESTIMATIVA DOS CUSTOS DE CONSTRUÇÃO DAS SUPERFÍCIES PAVIMENTADAS PARA OPERAÇÕES DE AERONAVES EM AEROPORTOS}

Considera-se, primeiramente, que um aeroporto é igual à somatória de partes em que pode ser subdividido. Matematicamente pode-se resumir esta afirmação como proposto na Equação 13:

Aeroporto $=$ Unidades $_{\text {parte } 1}+$ Unidades parte $2+$ Unidades $_{\text {parte } n}$

As partes indicadas na Equação 13, como 1, 2 e n, são as diversas partes que compõem um aeroporto, conforme apresentado no Capítulo 2. No entanto, as partes do empreendimento aeroportuário consideradas na modelagem paramétrica, e que envolvem atividades de construção civil, são:

- Pista de pouso e decolagem (PPD);

\footnotetext{
${ }^{9}$ Considerando base de custos para jul/2018.
} 
- Pistas de táxi (PTX);

- Pátio de estacionamento de aeronaves (PEA).

Aplicando-se uma modelagem paramétrica, o custo pode ser calculado segundo a Equação 14:

Custo Aeroporto = Custo unitário parte $1_{1}$ Quantidade $_{\text {parte } 1}+$ Custo unitário $_{\text {parte } 2} *$

Quantidade parte $2+$ Custo unitário parte $n^{*}$ Quantidade parte $n$

Dessa forma, o custo de construção das superfícies pavimentadas para operação de aeronaves de um aeroporto, seguindo o modelo proposto nesse trabalho, será expresso segundo a Equação 15:

Custo $_{\text {Sup.Pav.Aeron. }}$

$$
\begin{aligned}
& =\text { Custo }_{P P D} * \text { Quantidade }_{P P D}+\text { Custo }_{P T X} * \text { Quantidade }_{P T X}+\text { Custo }_{P E A} \\
& * \text { Quantidade }_{P E A}
\end{aligned}
$$

O Quadro 4 apresenta a forma como os parâmetros aplicados na modelagem, que influenciam os custos de construção das superfícies pavimentadas destinadas ao trânsito de aeronaves de aeroportos, exercem sua influência.

\begin{tabular}{|c|c|}
\hline Elemento & Parâmetros \\
\hline $\begin{array}{l}\text { Pista de Pouso } \\
\text { e Decolagem } \\
\text { (PPD) }\end{array}$ & $\begin{array}{l}\text { - Aeronave de projeto, Altitude da localidade, Temperatura de referência da } \\
\text { região - impacta no comprimento requerido da PPD; } \\
\text { - Demanda, Tipo de solo (subleito) - impacta no dimensionamento do pavimento. }\end{array}$ \\
\hline $\begin{array}{l}\text { Pistas de táxi } \\
\text { (PTX) }\end{array}$ & $\begin{array}{l}\text { - Aeronave de projeto, Forma de atendimento do aeroporto (concentração ou não } \\
\text { - de demanda em horários de pico) - impacta no dimensionamento das PTX; } \\
\text { - Demanda, Tipo de solo (subleito) - impacta no dimensionamento do pavimento. }\end{array}$ \\
\hline $\begin{array}{l}\text { Pátio de } \\
\text { estacionamento } \\
\text { de aeronaves } \\
\text { (PEA) }\end{array}$ & $\begin{array}{l}\text { - Aeronave de Projeto, Demanda - impacta no dimensionamento da área } \\
\text { destinada ao PEA } \\
\text { - Demanda, Tipo de solo (subleito) - impacta no dimensionamento do pavimento. }\end{array}$ \\
\hline
\end{tabular}

Quadro 4 - Principais parâmetros influenciadores nos custos de construção - PPD, PTX e PEA

Fonte: Elaboração própria 
A Figura 32 apresenta, em forma de fluxo a forma modelada para estimativa dos custos de construção das superfícies pavimentadas para operação de aeronaves em aeroportos.

Figura 32 - Fluxograma para estimativa dos custos de construção das superfícies pavimentadas para operação de aeronaves em aeroportos

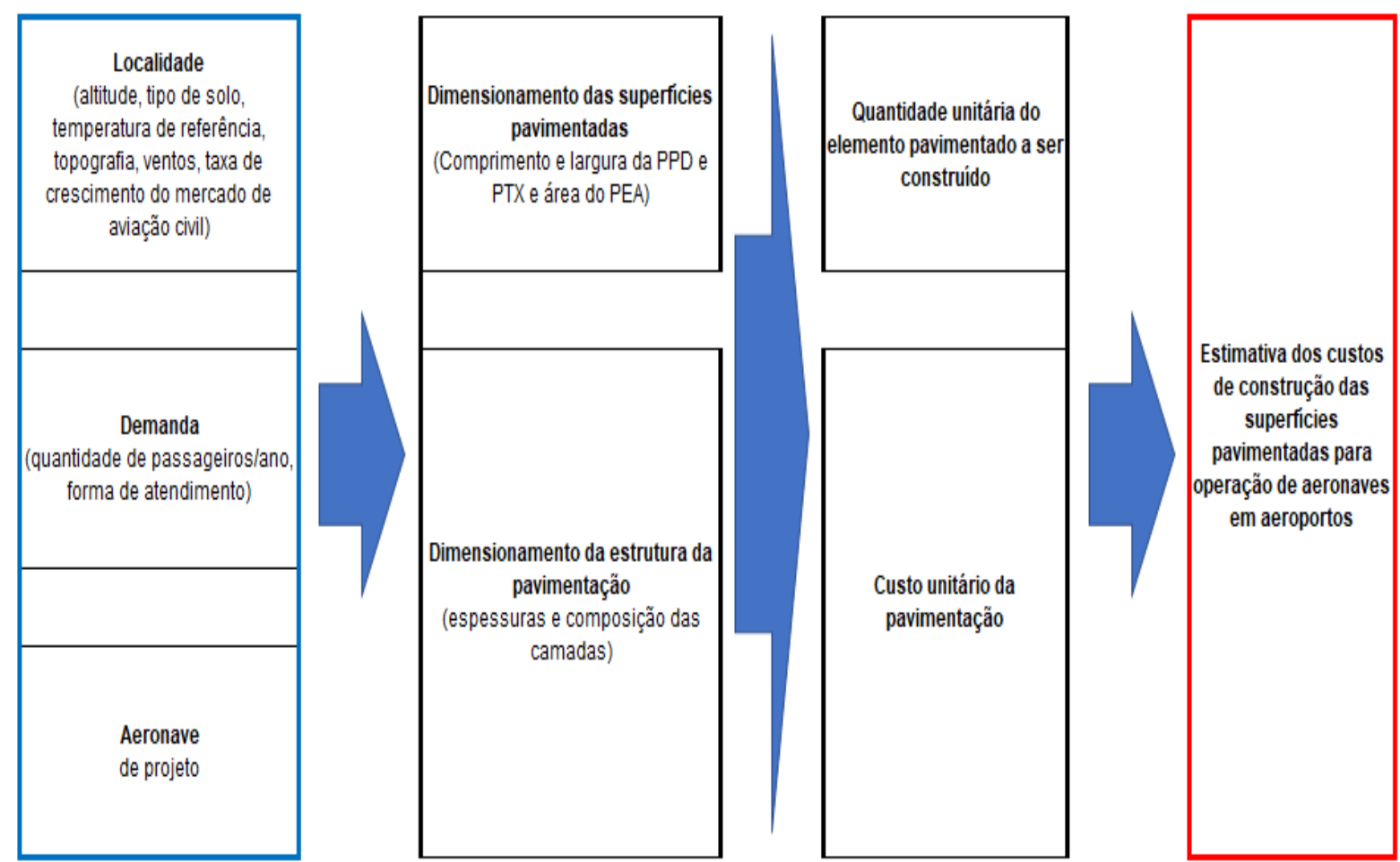

Fonte: Elaboração própria

O Quadro 5 apresenta, sob forma sinóptica, o modelamento paramétrico desenvolvido no trabalho. Em linhas gerais, através de parametrização dos aspectos físicos das áreas a serem pavimentadas, aplicando-se os princípios da modelagem paramétrica, obtém-se as estimativas de custos, quando se multiplica esses parâmetros físicos pelos parâmetros de custos. 
Quadro 5 - Quadro sinóptico com o modelamento paramétrico desenvolvido

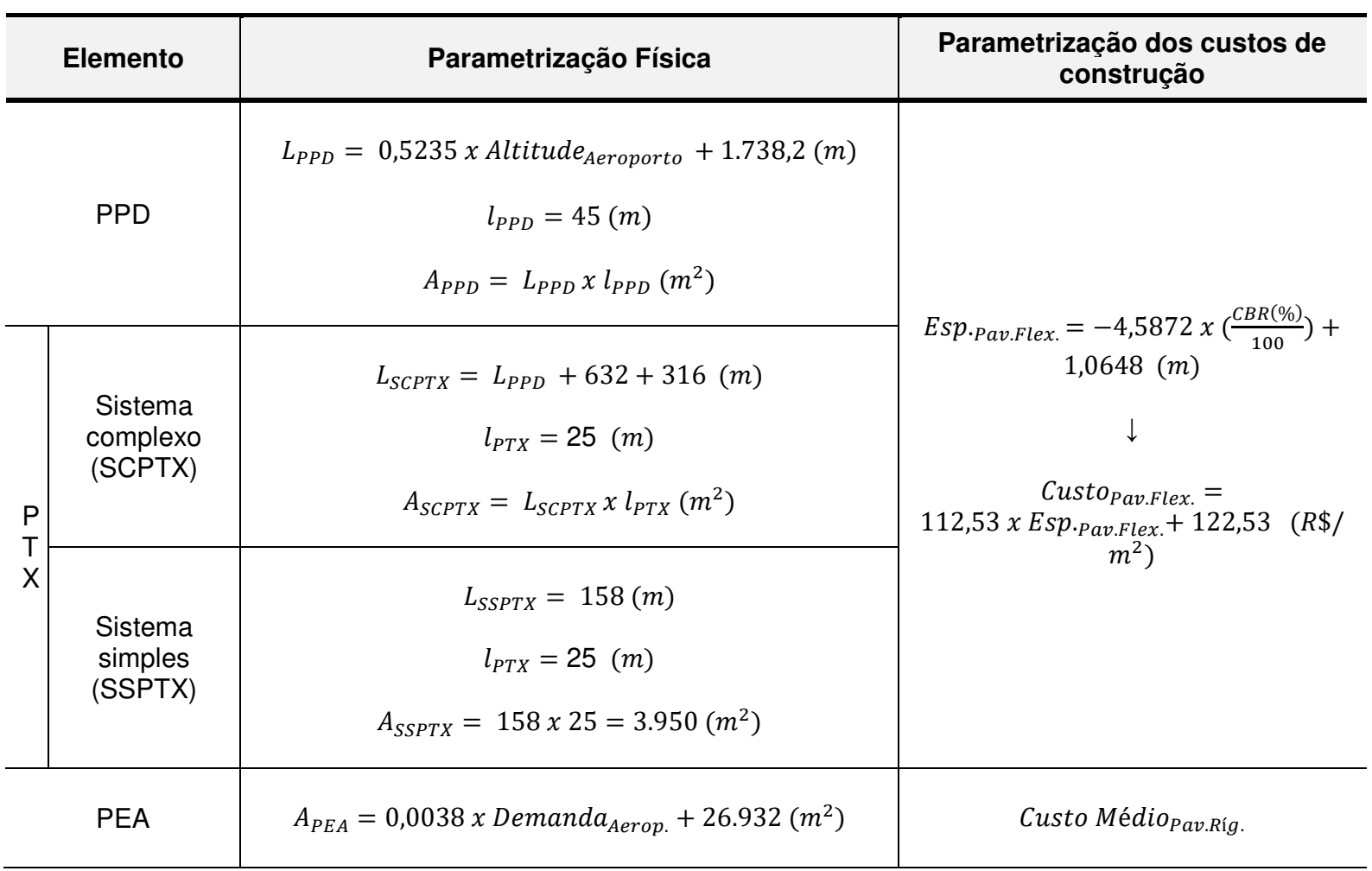

Onde:

$L_{P P D}=$ Comprimento da pista de pouso e decolagem

$l_{P P D}=$ Largura da pista de pouso e decolagem

$A_{P P D}=$ Área de superfície pavimentada da pista de pouso e decolagem

$L_{S C P T X}=$ Comprimento total do sistema complexo de pistas de táxi

$l_{P T X}=$ Largura das pistas de táxi

$A_{S C P T X}=$ Área de superfície pavimentada do sistema complexo de pistas de táxi

$L_{S S P T X}=$ Comprimento total do sistema simples de pista de táxi

$A_{S S P T X}=$ Área de superfície pavimentada sistema simples de pista de táxi

$A_{P E A}=$ Área pavimentada do pátio de estacionamento de aeronaves

Esp.Pav.Flex. $=$ Espessura total do pavimento flexível

Custo $_{\text {Pav.Flex. }}=$ Custo do pavimento flexível

Custo Médio ${ }_{\text {Pav.Ríg. }}=$ Custo médio do pavimento rígido (definido nesse trabalho)

Fonte: Elaboração própria, com base em SINAPI (jul/2018) 


\section{APLICAÇÃO DO MODELO PARAMÉTRICO DESENVOLVIDO}

Com o intuito de demonstrar a aplicação da modelagem desenvolvida, seguindo o objetivo principal do trabalho, qual seja, o de desenvolver um modelo fácil de aplicar e baseado nos parâmetros utilizados para o estudo de aeroportos, quatro empregos do modelo são expostos (considerando o escopo do trabalho):

- Estimativa do custo de construção das superfícies pavimentadas para operação de aeronaves de um aeroporto;

- Análise comparativa de custos de construção, considerando o impacto da localização de um aeroporto e o impacto do tipo de pavimentação;

- Análise dos custos de construção frente às operações aéreas;

- Avaliação das pistas de pouso e decolagem (PPD) dos aeroportos brasileiros

\subsection{ESTIMATIVA DOS CUSTOS DE CONSTRUÇÃO}

Nesta aplicação do modelamento paramétrico desenvolvido, busca-se apresentar o uso da ferramenta para estimar os custos de construção dos elementos escopo deste trabalho.

Para exemplificar a aplicação, consideremos que um empreendedor de infraestrutura aeroportuária esteja avaliando a construção de um aeroporto no Brasil, em localidade com altitude em relação ao nível do mar de $500 \mathrm{~m}$, subleito (solo original) com CBR igual a 3\%. A demanda a ser atendida seria de aproximadamente 4.000.000 passageiros/ano. Seria também requerido Sistema Complexo de Pistas de Táxi (SCPTX) (seguindo o apresentado na seção 5.2.3 desse trabalho). A pavimentação da PPD e SCPTX seria flexível (com revestimento asfáltico) e o Pátio de estacionamento de aeronaves (PEA) receberia pavimentação rígida (revestimento com placas rígidas de cimento Portland.

O Quadro 6 matematiza a exemplificação: 
Quadro 6 - Matematização de exemplificação com aplicação do modelamento paramétrico

\begin{tabular}{|c|c|c|c|}
\hline \multicolumn{2}{|r|}{ Elemento } & Parametrização Física & $\begin{array}{l}\text { Parametrização dos custos de } \\
\text { construção }\end{array}$ \\
\hline \multicolumn{2}{|r|}{ PPD } & $\begin{array}{c}L_{P P D}=\left(0,5235 \times \text { Altitude }_{P P D}+1.738,2\right)(\mathrm{m}) \\
L_{P P D}=(0,5235 \times 500+1.738,2)=2.000(\mathrm{~m}) \\
l_{P P D}=45(\mathrm{~m}) \\
A_{P P D}=L_{P P D} \times l_{P P D}\left(\mathrm{~m}^{2}\right) \\
A_{P P D}=2.000 \times 45=90.000\left(\mathrm{~m}^{2}\right)\end{array}$ & 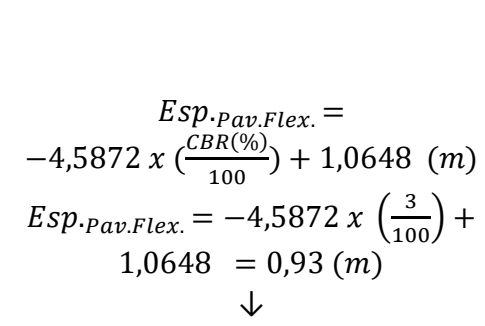 \\
\hline $\begin{array}{l}P \\
T \\
X\end{array}$ & $\begin{array}{l}\text { Sistema } \\
\text { complexo } \\
\text { (SCPTX) }\end{array}$ & $\begin{array}{c}L_{S C P T X}=2.000+632+316=2.948(\mathrm{~m}) \\
l_{P T X}=25(\mathrm{~m}) \\
A_{S C P T X}=L_{S C P T X} \times l_{P T X}\left(\mathrm{~m}^{2}\right) \\
A_{S C P T X}=2.948 \times 25=73.700\left(\mathrm{~m}^{2}\right)\end{array}$ & $\begin{array}{l}\text { Custo }_{\text {Pav.Flex. }} \\
\quad=112,53 \times \text { Esp.Pav.Flex. } \\
+122,53\left(R \$ / \mathrm{m}^{2}\right) \\
\text { Custo }_{\text {Pav.Flex. }}=112,53 \times 0,93+ \\
122,53=227,18\left(\mathrm{R} \$ / \mathrm{m}^{2}\right)\end{array}$ \\
\hline & PEA & $\begin{array}{c}A_{P E A}=0,0038 \times \text { Demanda }_{\text {Aerop. }}+26.932\left(\mathrm{~m}^{2}\right) \\
A_{P E A}=0,0038 \times 4.000 .000+26.932=42.132\left(\mathrm{~m}^{2}\right)\end{array}$ & $\begin{array}{c}\text { Custo Médio }{ }_{\text {Pav.Ríg. }}=309,44(R \$ / \\
\left.m^{2}\right)\end{array}$ \\
\hline
\end{tabular}

Fonte: Elaboração própria

Com isso, os custos para execução das superfícies pavimentadas para operação de aeronaves num aeroporto, com as condições de contorno anteriormente simuladas, seriam:

$$
\begin{gathered}
\text { Custo }_{P P D}=227,18 * 90.000=R \$ 20.446 .200,00 \\
\text { Custo }_{P T X}=227,18 * 73.700=R \$ 16.743 .166,00 \\
\text { Custo }_{P E A}=309,44 * 42.132=R \$ 13.037 .326,08 \\
\text { Custo }_{\text {Sup.Pav.Aerop. }}=\text { Custo }_{P P D}+\text { Custo }_{P T X}+\text { Custo }_{P E A}=R \$ 50.226 .692,08
\end{gathered}
$$

Esse exemplo define a forma para aplicação do modelo paramétrico desenvolvido. Apenas com informações preliminares, e de forma expedita, pode-se obter o custo para execução de todas as superfícies ou qualquer delas em específico.

De maneira a complementar o exposto, cabe ainda considerar a compatibilidade da modelagem paramétrica para levantamento dos custos frente a modelos concebidos com o emprego do BIM através, principalmente, dos softwares Grasshopper e 
Dynamo / Revit, mesmo que a partir de modelagens em versões preliminares (nível de desenvolvimento inicial).

\subsection{ANÁlISE COMPARATIVA DOS CUSTOS DE CONSTRUÇÃO - IMPACTO DA LOCALIDADE E TIPO DE PAVIMENTAÇÃO}

Nesta aplicação do modelamento paramétrico desenvolvido, busca-se apresentar como o uso da ferramenta elaborada permite, além de estimar os custos de construção dos elementos escopo desse trabalho, fornecer subsídios para comparação de alternativas.

Como discorrido no desenvolvimento do texto, a localidade, sendo uma informação preliminar conhecida e básica, permite, de forma expedita, indicar características sobre o local de implantação do empreendimento estudado em suas etapas preliminares.

Essas características, que são utilizadas para estimar os custos das superfícies pavimentadas para operações de aeronaves no modelo paramétrico desenvolvido, são: altitude de implantação da Pista de pouso e decolagem (PPD), região na qual será implantado o empreendimento (uma dentre as cinco do país), temperatura de referência e características gerais sobre o solo original do local (no caso, capacidade estimada de suporte do subleito). Como anteriormente descrito, cada uma dessas características influencia no dimensionamento dos elementos construídos de um aeroporto, em especial, o principal elemento, a PPD.

Para exemplificar a aplicação, considere-se que um empreendedor de infraestrutura aeroportuária esteja avaliando a construção de um aeroporto no Brasil em uma região com elevado desenvolvimento turístico e vocação para desenvolvimento de empresas do setor de tecnologia, sendo que ele tem como opção dois grandes lotes disponíveis (Localidade A e Localidade B) para abrigar um aeroporto, num raio de distância entre os mesmos de aproximadamente $60 \mathrm{~km}$. Esse aeroporto, independentemente do terreno que seja escolhido, atenderia às mesmas cidades. 
A diferença entre essas duas opções para locação do empreendimento aeroportuário seria a altitude e a capacidade de suporte do subleito. No terreno da Localidade $A$, a altitude é 112 m em relação do nível do mar e o CBR do subleito 15\%; na Localidade $\mathrm{B}$, a altitude é $535 \mathrm{~m}$ em relação do nível do mar e o CBR do subleito 3\%. A demanda a ser atendida em qualquer opção seria 3.500.000 de passageiros/ano, com taxa de crescimento do mercado de aviação brasileiro de 3,35\% ao ano.

Com as características apontadas, a maioria dos passageiros que acessarão 0 terminal estarão viajando em concentrados - horários de pico de demanda pelas manhãs e início das noites, principalmente às segundas-feiras e sextas-feiras, bem como no início de períodos de férias escolares e feriados nacionais. Esse fato leva à necessidade de implantação de um Sistema Complexo de Pistas de Táxi (SCPTX).

Seguindo o usualmente implantado no país, as superfícies para movimentação das aeronaves serão pavimentadas com revestimento asfáltico, com exceção do Pátio de estacionamento de aeronaves (PEA) será pavimentado com placas rígidas de concreto de cimento Portland.

Resumindo, para aplicação do modelo paramétrico:

- Localidade A: a) Altitude: 535 m; b) CBR do subleito: 15\%; c) Demanda: 3.500.000 passageiros/ano; d) Implantação de um SCPTX; e) Pavimentação flexível na PPD e SCPTX / Pavimentação rígida no PEA.

- Localidade B: a) Altitude: 112 m; b) CBR do subleito: 3\%; c) Demanda: 3.500.000 passageiros/ano; d) Implantação de um SCPTX; e) Pavimentação flexível na PPD e SCPTX / Pavimentação rígida no PEA.

Empregando o modelo paramétrico, o Quadro 7 apresenta a estimativa dos custos de construção das superfícies pavimentadas para operação de aeronaves nos aeroportos considerados na exemplificação. 
Quadro 7 - Exemplificação com aplicação do modelamento paramétrico

\begin{tabular}{|c|c|c|}
\hline \multicolumn{3}{|c|}{ Localidade A } \\
\hline Elemento & Parametrização Física & $\begin{array}{c}\text { Parametrização dos custos de } \\
\text { construção }\end{array}$ \\
\hline PPD & $\begin{array}{c}L_{P P D}=\left(0,5235 \times \text { Altitude }_{P P D}+1.738,2\right)(\mathrm{m}) \\
L_{P P D A}=(0,5235 \times 535+1.738,2)=2.018(\mathrm{~m}) \\
l_{P P D}=45(\mathrm{~m}) \\
A_{P P D A}=L_{P P D A} \times l_{P P D}\left(\mathrm{~m}^{2}\right) \\
A_{P P D A}=2.018 \times 45=90.810\left(\mathrm{~m}^{2}\right)\end{array}$ & 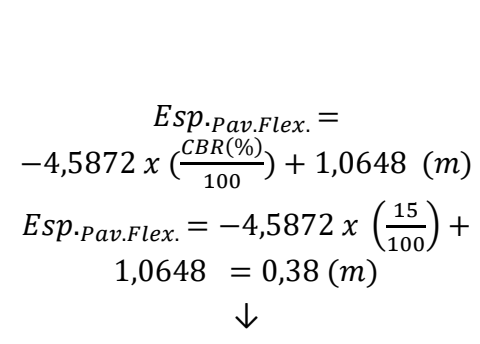 \\
\hline $\begin{array}{c}\text { Sistema } \\
\text { complexo } \\
\text { (SCPTX) }\end{array}$ & $\begin{array}{c}L_{S C P T X}=2.018+632+316=2.966(\mathrm{~m}) \\
l_{P T X}=25(\mathrm{~m}) \\
A_{S C P T X}=L_{S C P T X} \times l_{P T X}\left(\mathrm{~m}^{2}\right) \\
A_{S C P T X A}=2.966 \times 25=74.150\left(\mathrm{~m}^{2}\right)\end{array}$ & $\begin{array}{c}=112,53 \times \text { Esp.Pav.Flex. } \\
+122,53\left(R \$ / \mathrm{m}^{2}\right) \\
\text { Custo }_{\text {Pav.Flex. }}=112,53 \times 0,38+ \\
122,53=165,29\left(R \$ / \mathrm{m}^{2}\right)\end{array}$ \\
\hline PEA & $\begin{array}{c}A_{P E A}=0,0038 \times \text { Demanda } a_{\text {erop. }}+26932\left(\mathrm{~m}^{2}\right) \\
A_{P E A A}=0,0038 \times 3.500 .000+26932=40.232\left(\mathrm{~m}^{2}\right)\end{array}$ & $\begin{array}{c}\text { Custo Médio }{ }_{\text {Pav.Ríg. }}=309,44(R \$ / \\
\left.m^{2}\right)\end{array}$ \\
\hline
\end{tabular}

\section{Localidade B}

\begin{tabular}{|c|c|c|}
\hline Elemento & Parametrização Física & $\begin{array}{c}\text { Parametrização dos custos de } \\
\text { construção }\end{array}$ \\
\hline PPD & $\begin{array}{c}L_{P P D}=\left(0,5235 \times \text { Altitude }_{P P D}+1.738,2\right)(\mathrm{m}) \\
L_{P P D B}=(0,5235 \times 112+1.738,2)=1.797(\mathrm{~m}) \\
l_{P P D}=45(\mathrm{~m}) \\
A_{P P D B}=L_{P P D B} \times l_{P P D}\left(\mathrm{~m}^{2}\right) \\
A_{P P D B}=1.797 \times 45=80.865\left(\mathrm{~m}^{2}\right)\end{array}$ & 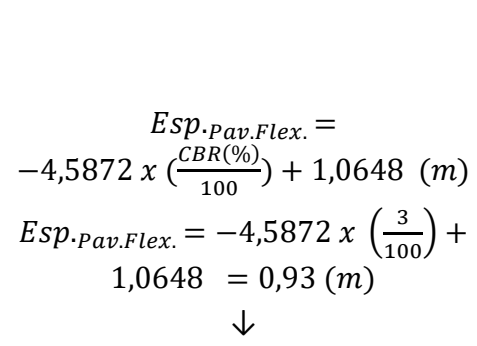 \\
\hline $\begin{array}{l}\text { Sistema } \\
\text { complexo } \\
\text { (SCPTX) }\end{array}$ & $\begin{array}{c}L_{S C P T X}=1.797+632+316=2.745(\mathrm{~m}) \\
l_{P T X}=25(\mathrm{~m}) \\
A_{S C P T X}=L_{S C P T X} x l_{P T X}\left(\mathrm{~m}^{2}\right) \\
A_{S C P T X B}=2.745 \times 25=68.625\left(\mathrm{~m}^{2}\right)\end{array}$ & $\begin{array}{c}=112,53 x \text { Esp.Pav.Flex. } \\
+122,53\left(R \$ / m^{2}\right) \\
\text { Custo }_{\text {Pav.Flex. }}=112,53 \times 0,93+ \\
122,53=227,18\left(R \$ / \mathrm{m}^{2}\right)\end{array}$ \\
\hline PEA & $\begin{array}{c}A_{P E A}=0,0038 \times \text { Demanda } a_{\text {Aerop. }}+26932\left(\mathrm{~m}^{2}\right) \\
A_{P E A B}=0,0038 \times 3.500 .000+26932=40.232\left(\mathrm{~m}^{2}\right)\end{array}$ & $\begin{array}{c}\text { Custo Médio }{ }_{\text {Pav.Ríg. }}=309,44(R \$ / \\
\left.m^{2}\right)\end{array}$ \\
\hline
\end{tabular}

Fonte: Elaboração própria 
Portando, o custo parametrizado das superfícies pavimentadas para operações de aeronaves em um aeroporto na Localidade A é obtido segundo:

$$
\begin{aligned}
\text { Custo }_{\text {Sup.Pav.Aerop. }} & =\text { Custo }_{P P D}+\text { Custo }_{P T X}+\text { Custo }_{P E A} \\
= & 165,29 * 90.810+165,29 * 74.150+309,44 * 40.232=R \$ 39.715 .628,48
\end{aligned}
$$

Os custos apresentados referem-se às planilhas de composição do SINAPI, base jul/2018. Cabe, ainda, frisar que os custos podem ser obtidos em outras fontes e, até mesmo, com base em cotações preliminares junto a fornecedores. O intuito primordial desse trabalho é apresenta o modelamento paramétrico para a atividade de estudos de viabilidade na área aeroportuária.

Já o custo parametrizado das superfícies pavimentadas para operações de aeronaves em um aeroporto na Localidade B é obtido segundo:

$$
\begin{aligned}
\text { Custo }_{\text {Sup.Pav.Aerop. }} & =\text { Custo }_{P P D}+\text { Custo }_{P T X}+\text { Custo }_{P E A} \\
& =227,18 * 80.865+227,18 * 68.625+309,44 * 40.232=R \$ 46.410 .528,28
\end{aligned}
$$

Verifica-se uma diferença, nos custos para construção das superfícies pavimentadas para trânsito de aeronaves em aeroportos, para a mesma finalidade e porte de aeroporto, de aproximadamente $\mathrm{R} \$ 6.700 .000,00$.

Demonstra-se, o impacto da capacidade de suporte de um solo com alto CBR (Localidade A), frente à localidade com um solo com menor capacidade de suporte (Localidade B), no que tange ao custo da pavimentação flexível.

A influência da altitude também pode ser verificada: quanto mais elevação em relação ao nível do mar, mantendo-se a temperatura, como no caso em análise, maior comprimento de PPD será requerido; no caso, a Localidade A requer $221 \mathrm{~m}$ (cerca de $10 \%$ ) mais de comprimento de PPD em relação à Localidade $B$, puramente por influência da altimetria, uma vez que temperatura de referência e demais fatores considerados mantiveram-se constantes.

Com base nesse resultado, o empreendedor pode fazer análises, mesmo em fases de estudo de viabilidade preliminares, com maior confiança. Vale ainda destacar que, para as outras partes (elementos) que compõem um aeroporto, os custos construtivos 
seriam provavelmente semelhantes, independentemente da localidade escolhida, uma vez que a demanda a ser atendida seria mesma.

A parametrização justamente nos elementos escopo desse trabalho, no tocante ao comprimento da PPD requerida, podem ajudar no estudo de viabilidade, seja comparando alternativas de posicionamento do aeroporto, ou seja na percepção do montante a ser investido na sua construção.

Por fim, ainda que não se verifique a existência de muitas PPD e PTX com pavimentação rígida no Brasil, uma análise comparativa dos custos de construção dos diferentes tipos de pavimentação pode interessar para estudos específicos na área da infraestrutura aeroportuária.

A Tabela 18 apresenta os custos parametrizados dos diferentes tipos de pavimentação.

Tabela 18 - Custos parametrizados de pavimentação

\begin{tabular}{|c|c|c|c|c|}
\hline \multirow{4}{*}{$\begin{array}{l}\text { Pavimento } \\
\text { Flexível }\end{array}$} & CBR (\%) & $\begin{array}{l}\text { Custo unitário } \\
\left(\mathrm{R} \$ / \mathrm{m}^{2}\right)\end{array}$ & \multirow{4}{*}{$\begin{array}{l}\text { Pavimento } \\
\text { Rígido }\end{array}$} & $\begin{array}{l}\text { Custo unitário }(R \$ / \\
\left.m^{2}\right)\end{array}$ \\
\hline & 3 & 229,86 & & \multirow{3}{*}{309,44} \\
\hline & 10 & 183,44 & & \\
\hline & 15 & 169,21 & & \\
\hline
\end{tabular}

Fonte: Elaboração própria

Essas diferenças de custos de construção para a pavimentação permitem que o empreendedor realize estudos e análises mais detalhados, considerando custos futuros com manutenibilidade e impactos nas operações aéreas com essas intervenções.

\subsection{ANÁLISE DOS CUSTOS DE CONSTRUÇÃO FRENTE ÀS OPERAÇÕES AÉREAS}

Nessa parte do trabalho o objetivo é aplicar o modelo para analisar os custos de construção de Pistas de táxi (PTX) frente ao impacto gerado nas operações aéreas. 
O raciocínio desenvolvido a seguir foi embasado pelo material de Ribeiro, G. (2014), no qual tece um panorama sobre o impacto que uma expansão do sistema de PTX teria no que tange ao aumento da capacidade da demanda do aeroporto de Curitiba.

Em horário de pico, o máximo tem sido 18 movimentos por hora, ou seja, 18 aeronaves podem pousar ou decolar em uma hora. Isso porque não há uma via de táxi que chegue até a cabeceira da pista mais utilizada. Sem esse acesso, as aeronaves precisam entrar na pista, percorrer cerca de 300 metros na "contramão", fazer a volta para alinhar e, então, realizar a corrida para decolar. A Figura 33 exemplifica graficamente esse fato.

Figura 33 - Pista de Táxi para maior fluxo de aeronaves (aeroporto de Curitiba)

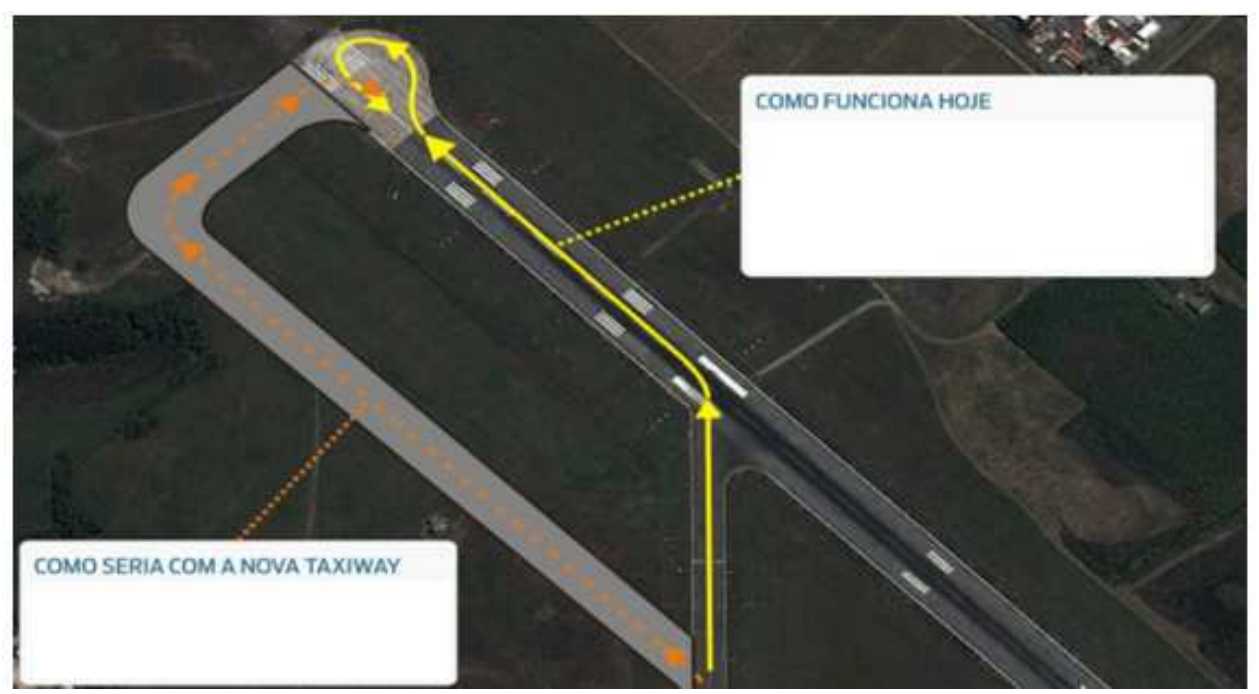

Fonte: RIBEIRO, G. (2014) - Adaptado

Para ampliar a capacidade do aeroporto, uma das Pistas de táxi de entrada, junto à cabeira, permitiria a ampliação da capacidade do aeroporto nas horas de maior demanda. Essa obra configura uma demanda antiga das companhias aéreas e dos órgãos de controle de tráfego aéreo, mas que não foi efetivada até o momento. Segundo a Infraero, esse empreendimento está em fase de análise e estudos.

Além da PTX supracitada e discutida, outra, no mesmo aeroporto, também ajudaria no aumento do fluxo de aeronaves; por conseguinte, na ampliação da sua capacidade. Hoje, quando as aeronaves pousam na cabeceira principal, elas precisam deixar a pista com velocidade reduzida, já que o ângulo da PTX de saída é bastante oblíquo. A Figura 34 exemplifica graficamente esse fato. 
Figura 34 - Pista de Táxi de saída rápida para maior fluxo de aeronaves (aeroporto de Curitiba)

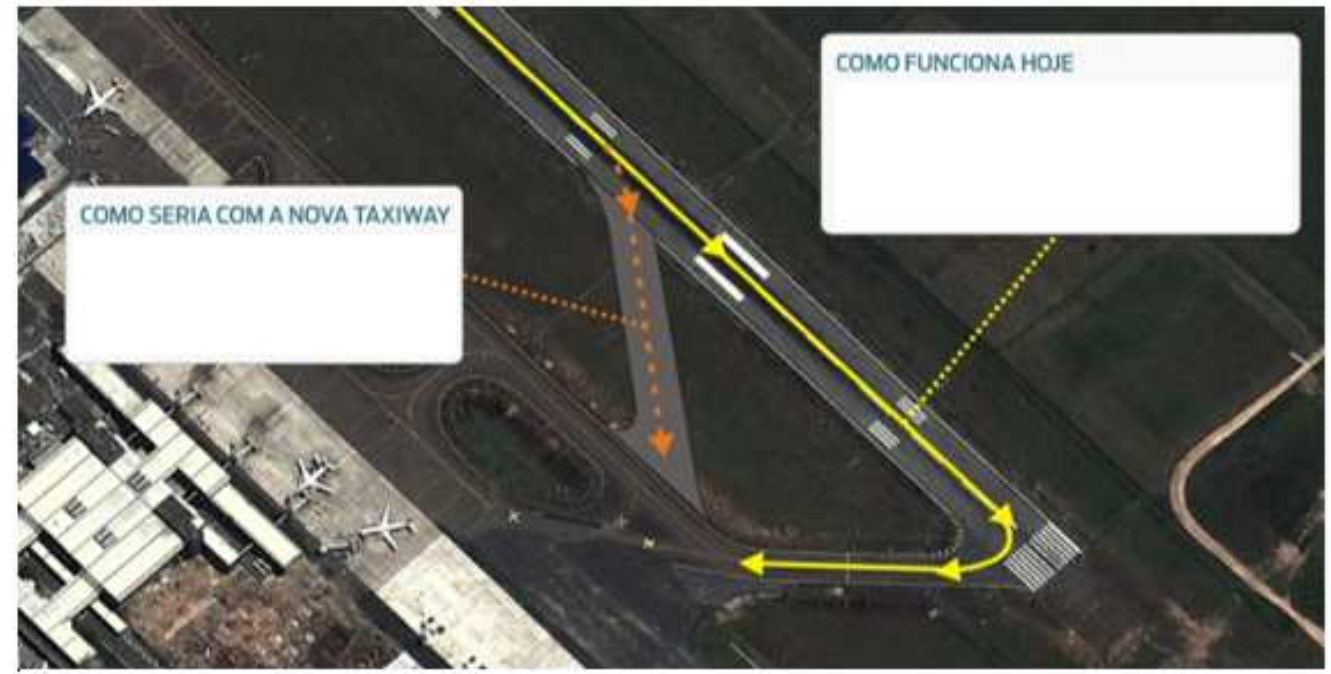

Fonte: RIBEIRO, G. (2014) - Adaptado

Nesse caso, a construção de uma PTX de saída rápida, em um ângulo favorável (cerca de $30^{\circ}$ ), permitiria às aeronaves livrarem, em menor tempo, a pista para um novo pouso ou uma decolagem.

Esses investimentos, tidos como menores, muitas vezes perdem espaço para busca de soluções de maior porte, como construção de pistas adicionais no aeroporto ou, até mesmo, construção de novos aeroportos; por isso, em casos como este, a construção de um sistema complexo de PTX (SCPTX) e com investimentos em menor valor, permitem acomodar substancial incremento de capacidade do aeroporto.

Empregando-se como base a aplicação da Seção 6.2, na Localidade B, o custo parametrizado para construção de um SCPTX é da ordem de $R \$ 15.500 .000,00$; já para construção de Sistema Simples de PTX (SSPTX) o custo é da ordem de R\$ 900.000. Nesse contexto, considerando todas as superfícies pavimentadas (PPD, PTX e PEA), no primeiro caso (SCPTX), o custo total dessas superfícies seria de aproximadamente $R \$ 46.400 .000,00$, enquanto que no segundo caso, com SSPTX, o custo total dessas superfícies seria de aproximadamente $R \$ 31.700 .000,00$, uma diferença global de aproximadamente $R \$ 14.700 .000,00$. Cerca de $31 \%$ nos custos de construção, considerando todas as superfícies pavimentadas (PPD, PTX e PEA).

Nesse caso, claramente a opção por um sistema ou outro de PTX, deve levar em consideração a análise detalhada sobre a concentração ou não da demanda em 
horários de pico, além dos recursos disponíveis para implantação do empreendimento aeroportuário.

Outra forma de observar a discussão dessa seção do trabalho é matematizando os ganhos operacionais de uma opção em relação a outra (SCPTX versus SSPTX). Tomando-se como base o preconizado em ANAC (2018a), para o importante aeroporto de Congonhas (localizado em São Paulo, maior e mais populosa cidade do Brasil, a capacidade atual de movimentos por hora (pousos e decolagens) de aeronaves comerciais, atualmente é cerca 35 movimentos. $O$ referido aeroporto possui um SCPTX.

Já caso o aeroporto fosse aparelhado com SSPTX, o número de movimentos por hora seria limitado a cerca de 15 movimentos por hora, segundo levantamento feito junto a especialistas e pilotos de aeronaves comerciais.

Caso seja interessante analisar sob o ponto de vista da quantidade de passageiros que podem ser transportados numa ou em outra alternativa (SCPTX versus SSPTX), a correlação é diretamente proporcional à quantidade de movimentos de aeronaves comerciais.

Continuando, para o caso supracitado do aeroporto de Congonhas, que em 2017, segundo INFRAERO (2018a), movimentou cerca de 21.000 .000 de passageiros, contanto com um SCPTX, caso operasse com um SSPTX, movimentaria apenas cerca de 9.000 .000 de passageiros, evidenciando a efetividade do investimento feito num SCPTX.

No Brasil, tipicamente, aeroportos da região Norte ou aeroportos regionais não necessitam de SCPTX, visto que as operações ocorrem de maneira esparsa ao longo dia ou apresentam número de operações de aeronaves (pouso e decolagem) não elevados. Nesses casos, a construção e manutenção de SCPTX seriam, numa abordagem simplista, não adequadas.

Já para os aeroportos de capitais populosas, é praticamente inconcebível não dotar aeroportos com SCPTX, uma vez que, sem os mesmos, longas filas de aeronaves são formadas e não se aproveita a capacidade instalada dos outros elementos que compõem o empreendimento aeroportuário. 


\subsection{AVALIAÇÃO DO COMPRIMENTO DE PISTAS DE POUSO E DECOLAGEM}

O comprimento da Pista de pouso e decolagem (PPD) é o principal parâmetro físico para a modelagem da estimativa dos custos de construção das superfícies pavimentadas para operação de aeronaves de um aeroporto.

Mesmo que não diretamente ligada a questão de avaliação dos custos de construção, essa Seção do trabalho apresenta uma útil finalidade para o modelamento desenvolvido, que seria a avaliação expedita da situação para operação de aeronaves em aeroportos já edificados.

Aplicando-se a parametrização física para determinação do comprimento da PPD, pode-se verificar a situação da segurança das operações para as aeronaves tipificadas para as operações domésticas brasileiras. Quando o cálculo do comprimento de pista necessário para determinada operação for superior ao comprimento de pista real disponível para operação, tem-se uma situação potencialmente insegura ou que não atende aos requisitos de segurança operacional para o aeroporto em questão.

Essa aplicação permite ainda retratar a realidade operacional dos importantes aeroportos Santos Dumont (localizado na cidade do Rio de Janeiro) e Congonhas (localizado na cidade de São Paulo). Nesses aeroportos as aeronaves operam rotas mais curtas, uma vez que o peso de decolagem é bastante limitado para se conseguir trabalhar com os comprimentos de pistas disponíveis.

Para manter uma ocupação de assentos alta, "compensa-se" com menor quantidade de combustível nos tanques, o que reduz o alcance das rotas a serem operadas nesses aeroportos.

A Tabela 19 apresenta os valores obtidos para o comprimento da PPD, aplicando a modelagem desenvolvida, frente aos valores dos comprimentos reais das PPD dos aeroportos caracterizados. 
Tabela 19 - Comprimento das PPD empregando a modelagem paramétrica desenvolvida em comparação com o comprimento real das PPD dos aeroportos caracterizados

\begin{tabular}{|c|c|c|c|}
\hline $\begin{array}{l}\text { Localidade do } \\
\text { aeroporto }\end{array}$ & Altitude (m) & $\begin{array}{l}\text { LPPD Mod.Paramétrico } \\
\qquad(\mathbf{m})\end{array}$ & LPPD Real (m) \\
\hline Belém & 15 & 1.746 & 2.800 \\
\hline Manaus & 78 & 1.779 & 2.700 \\
\hline Macapá & 14 & 1.746 & 2.100 \\
\hline Palmas & 228 & 1.858 & 2.500 \\
\hline Porto Velho & 87 & 1.784 & 2.400 \\
\hline Rio Branco & 187 & 1.836 & 2.158 \\
\hline Santarém & 56 & 1.768 & 2.400 \\
\hline Aracaju & 7 & 1.742 & 2.200 \\
\hline João Pessoa & 65 & 1.772 & 2.515 \\
\hline Juazeiro do Norte & 420 & 1.958 & 1.800 \\
\hline Maceió & 115 & 1.799 & 2.602 \\
\hline Petrolina & 382 & 1.938 & 3.250 \\
\hline Recife & 10 & 1.743 & 3.007 \\
\hline São Luís & 49 & 1.764 & 2.385 \\
\hline Teresina & 63 & 1.771 & 2.200 \\
\hline Campo Grande & 557 & 2.030 & 2.600 \\
\hline Cuiabá & 184 & 1.834 & 2.300 \\
\hline Goiânia & 747 & 2.129 & 2.286 \\
\hline Rio de Janeiro & 3 & 1.740 & 1.323 \\
\hline São Paulo & 800 & 2.157 & 1.940 \\
\hline Uberlândia & 941 & 2.231 & 2.100 \\
\hline Vitória & 8 & 1.742 & 2.058 \\
\hline Curitiba & 908 & 2.214 & 2.218 \\
\hline Foz do Iguaçu & 236 & 1.862 & 2.195 \\
\hline Joinville & 4 & 1.741 & 1.540 \\
\hline Londrina & 560 & 2.032 & 2.100 \\
\hline Navegantes & 5 & 1.741 & 1.701 \\
\hline
\end{tabular}

Fonte: Elaboração própria, com base em DECEA (2019)

Com base na comparação dos valores obtidos para os comprimentos de PPD com a aplicação do modelo e os valores existentes (reais), pode-se concluir que, para a grande maioria dos aeroportos é possível operação com a aeronave de projeto com maior peso de decolagem ou ainda aeronaves de maior porte.

Exceções devem ser aplicadas para os aeroportos localizados nas cidades de Juazeiro do Norte, Rio de Janeiro, São Paulo, Uberlândia e Navegantes, que 
permitiriam a operação da aeronave de projeto apenas com menor peso de decolagem (ou seja com menor quantidade de combustível ou passageiros e cargas). Por fim, o modelo para definição do comprimento da PPD é determinístico e baseado nas regras e normativos vigentes na área aeroportuária. Portanto, ele é correto. O que se faz nessa seção do trabalho é uma análise dos aeroportos brasileiros face ao comprimento de PPD que o modelo calcularia. 


\section{CONCLUSÕES E CONSIDERAÇÕES FINAIS}

O desenvolvimento do trabalho permitiu: a reunião de referências da literatura sobre estimativa de custos de construção civil, o entendimento do produto aeroporto e a modelagem paramétrica dos custos envolvidos na construção de uma de suas principais partes - as superfícies pavimentadas para operação de aeronaves. Inovou com a apresentação de um modelo paramétrico simples, que permite estimar o custo das superfícies pavimentadas para operações de aeronaves em aeroportos, apenas com informações preliminares sobre o empreendimento.

Essas informações preliminares dizem respeito: à localidade de implantação e à demanda a ser atendida.

Quanto à localidade de implantação, obtém-se, de forma expedita, fatores físicos como: altitude em relação ao nível do mar, tipo de solo (capacidade de suporte do subleito), além da Região do país, da qual depreende-se a temperatura média de referência. Todos esses fatores são empregados nas parametrizações apresentadas.

Quanto aos objetivos indicados no Capítulo 1, todos puderam ser alcançados, incluindo a aplicação da modelagem paramétrica, em estudos hipotéticos, que visam atender a aplicações comumente conferidas a empreendedores e planejadores de infraestrutura aeroportuária.

O trabalho apresenta, justamente, uma ferramenta para melhor servir ao propósito de obterem-se custos de construção mais realistas e próximos dos gastos reais a serem despendidos em determinado empreendimento, num momento de nível de informações inicial, através da parametrização das principais variáveis que interferem nos custos de construção de aeroportos.

A matematização objetiva, inserida no modelo, deixa muito menos espaço para subjetividade na estimação dos custos de construção.

O modelo paramétrico desenvolvido permite estimar os custos de construção de um dos elementos mais importantes no que se refere ao dimensionamento de um aeroporto. 
Esse elemento é a Pista de pouso e decolagem (PPD). O comprimento da PPD influencia ainda o dimensionamento de outros componentes, como o sistema de Pistas de táxi. A parametrização elaborada levou em consideração normativos nacionais e internacionais, especificações e estudos sobre desempenho de aeronaves, além de aplicação de teorias das cadeiras de estatística e custos na construção civil.

A relevância de toda a pesquisa realizada pode ser constatada através da aplicação da modelagem de forma prática e simples. Os resultados obtidos, embora não aplicados a um caso real, permitiram apontar a viabilidade da adoção de modelos paramétricos nas discussões inseridas nos planejamentos e estudos de projetos de aeroportos futuros.

$\mathrm{Na}$ medida em que o modelo foi desenvolvido com uma base "física", onde as características de cada alternativa foram expressas através de parâmetros objetivos e quantificáveis, trata-se de algo tão bom quanto o sejam os parâmetros usados como entrada para o mesmo. E mostrou-se também de fácil aplicação. Certamente aprimoramentos complementares deverão acontecer, mas aqui já se deu uma contribuição bastante relevante para o assunto.

Muitas vezes, principalmente órgãos governamentais (responsáveis, até o momento, por grande parte dos recursos investidos no desenvolvimento da infraestrutura aeroportuária brasileira), por disporem de parcos sistemas normativos, recursos e registros sobre projetos anteriores, acabam por empregar simples analogias de projetos "semelhantes" para estimar custos de construção.

Ressalta-se que essas analogias embasam importantes decisões sobre viabilidade de investimento em aeroportos e que, como já comentado, não existem no mundo dois aeroportos iguais; por conseguinte, nunca existirão dois projetos iguais, com custos de construção iguais.

Quanto a uma análise dos resultados referentes à parametrização de custos, a Tabela 20 apresenta uma valoração de referência (ainda que simplista) dos ônus médios unitários para execução de pavimentação aeroportuária, para as condições impostas neste modelamento. 
Tabela 20 - Custos médios para pavimentação de aeroportos

\begin{tabular}{ll}
\hline Custos Médios & $\mathbf{R} \$ \mathbf{m}^{\mathbf{2}}$ \\
\hline Pavimento flexível & 194,17 \\
\hline Pavimento rígido & 309,44 \\
\hline Pavimento flexível em solo com CBR $=3 \%$ & 229,86 \\
\hline Pavimento flexível em solo com CBR $=10 \%$ & 183,44 \\
\hline Pavimento flexível em solo com CBR $=15 \%$ & 169,21 \\
\hline
\end{tabular}

Fonte: Elaboração Própria, com base em SINAPI (jul/2018)

Frente às várias simulações, verifica-se que, em geral, a decisão que apresenta maior impacto sobre o custo médio de produção de PPD de aeroportos é o tipo de pavimento a ser aplicado.

Enquanto que, para um pavimento aeroportuário com revestimento flexível, apurouse custo médio de $R \$ 194,17$ por $\mathrm{m}^{2}$, para um revestimento com placas rígidas de concreto apurou-se custo médio de $\mathrm{R} \$ 309,44$ por $\mathrm{m}^{2}$.

O tipo de solo original que caracteriza o subleito, sobre o qual será assentada toda a estrutura da pista, também apresentou significativa contribuição; no entanto, com menor amplitude em relação ao citado no parágrafo anterior. Para pavimentação flexível, o custo oscilou entre $R \$ 229,86$ por $\mathrm{m}^{2}$ e 169,21 por $\mathrm{m}^{2}$. Já na pavimentação rígida, pode-se considerar (dentro das hipóteses assumidas no desenvolvimento do modelo) que o custo médio não apresenta significativa variação, independentemente da capacidade de suporte do subleito ou demanda a ser atendida.

Quanto à parametrização física empregada para dimensionamento dos elementos, verificou-se que a altitude é o fator que mais influencia no comprimento da PPD e, por conseguinte, nos custos estimados de construção.

Resta comentar que as parametrizações aqui trabalhadas não são exaustivas, permitindo analisar alguns (e não todos) cenários e possibilidades para otimização do emprego de recursos, no que tange aos custos de construção.

Quanto à construção das demais partes (elementos) que compõe um aeroporto (Edifício Terminal de Passageiros, Estacionamento de veículos e Obras complementares), neste trabalho, não se aplicou nenhuma modelagem para 
estabelecimento de custos de construção dos mesmos, visto a delimitação do escopo discutida no Capítulo 1.

Modelagens paramétricas, como as executadas para o caso das estimativas de custos para execução dos serviços que envolvem movimento de terra (terraplenagem), para construção das superfícies pavimentadas e para os demais elementos, seriam bastante complexas, no que tange ao seu desenvolvimento e aplicação, fato que justifica não estarem também incorporadas ao modelo, sendo ideal para um outro futuro trabalho acadêmico específico.

No entanto, as mesmas bases empregadas podem servir de suporte a futuros desenvolvimentos para modelos paramétricos que contemplem todas as partes (elementos) que formam um aeroporto.

Os exemplos de aplicação, presentes no Capítulo 6, evidenciam a forma como a ferramenta desenvolvida pode auxiliar o empreendedor ou planejador de infraestrutura aeroportuária na análise de projetos e definições para futuros projetos, considerando o competitivo mercado da aviação, necessidades das companhias aéreas e os recursos disponíveis para construção de novos aeroportos.

Através da modelagem paramétrica, pode-se estimar, com precisão adequada aos estágios preliminares de desenvolvimento de planos e projetos da área de infraestrutura aeroportuária, momento no qual são fortes as discussões quanto à viabilidade.

O valor do trabalho proposto deve considerar ainda o pertinente extrato elaborado por Piketty (2014), que em seu amplo estudo sobre economia, destaca que não é fácil determinar, de forma precisa, o valor de mercado dos edifícios públicos ou das infraestruturas de transportes, visto que não são vendidos com regularidade. Ainda indica que os cálculos elaborados usam como referência os preços observados em vendas similares efetuadas no passado recente. Nesse contexto, o trabalho apresenta justamente uma ferramenta para extração de informações de melhor qualidade para estimar esses valores, diferente do comumente empregado e descrito na passagem.

Considerando ainda o fato de existência de pouca literatura sobre todo o assunto tratado e o estado do conhecimento sobre a modelagem paramétrica aplicada a obras 
de infraestrutura aeroportuária, fica esse trabalho como base para futuros desenvolvimentos sobre o tema.

Do ponto de vista profissional, a realização deste trabalho apresentou relevância para a jornada do autor. De forma imediata, os frutos dessa pesquisa, ainda que não diretamente empregados na construção de aeroportos, formarão em compêndios para empregado no auxílio de fiscalizações sobre segurança operacional nas operações de aeronaves em aeroportos brasileiros.

Como passos futuros, o autor pretende avançar, apresentando e aplicando a modelagem paramétrica desenvolvida para estimar custos de construção e estudos de viabilidade de projetos reais de aeroportos brasileiros.

Outra possibilidade, avençada pelo autor, seria a possibilidade de expansão do modelo paramétrico, para estimativa dos custos de construção envolvidos com a terraplenagem de áreas para implantação de sítios aeroportuários.

Para aprimoramento do modelo matemático, futuros pesquisadores podem, a partir desse início, aplicar mecanismos para validação de todas as condições de contorno. Projetos ligados às cadeiras de logística e transportes podem também enxergar nesse trabalho oportunidades de aprimoramentos e adições de fatores.

Para pesquisas futuras justamente na área de concentração que está inserido este projeto - engenharia de construção civil (tecnologia e gestão da produção) - diversas possibilidades podem ser apontadas, iniciando-se com a aplicação e desenvolvimento de modelo para estimar custos de construção de outras edificações aeroportuárias, como terminal de passageiros e as construções acessórias que compõem o produto aeroporto. 


\section{REFERÊNCIAS}

ABREU, T. P. Análise de escolha aeroportuária em uma região de múltiplos aeroportos: um estudo de caso considerando um novo aeroporto para São Paulo. 2017. 118 f. Dissertação (Mestrado). Instituto Tecnológico de Aeronáutica, São José dos Campos, 2017.

ACRP - AIRPORT COOPERATIVE RESAERCH PROGRAM. Airport Passenger Terminal Planning and Design, Volume 1: Guidebook, ACRP Report 25, Washington, D.C., 2010.

2008.

Innovations for Airport Terminal Facilities, ACRP Report 10, Washington, D.C.,

AGOPYAN, V. A engenharia não é uma ciência exata. Folha de S. Paulo. São Paulo, 21 fev. 2019. Disponível em: <https://www1.folha.uol.com.br/opiniao/2019/02/a-engenharia-nao-euma-ciencia-exata.shtml>. Acesso em 26 de fevereiro de 2019.

AIRBUS S.A.S. Portal. 2019. Disponível em: < https://www.airbus.com/aircraft.html>. Acesso em 07 de fevereiro de 2019.

ANAC - AGÊNCIA NACIONAL DE AVIAÇÃO CIVIL. BRASIL. Portal. 2018a. Disponível em: $<$ https://www.anac.gov.br/>. Acesso em 02 de julho de 2018.

Regulamento Brasileiro da Aviação Civil no 153 - Emenda no 03 - Título: Aeródromos - Operação, Manutenção e Resposta à Emergência. Brasília: ANAC, 2019a. Disponível em: <https://www.anac.gov.br/assuntos/legislacao/legislacao-1/rbha-erbac/rbac/rbac-153-emd-03/@@display-file/arquivo_norma/RBAC153EMD03.pdf>. Acesso em 17 de fevereiro de 2019.

Regulamento Brasileiro da Aviação Civil no 154 - Emenda no 04 - Título: Projeto de Aeródromos. Brasília: ANAC, 2018b. Disponível em: $<$ https://www.anac.gov.br/assuntos/legislacao/legislacao-1/rbha-e-rbac/rbac/rbac-154-emd04/@@display-file/arquivo_norma/RBAC154EMD04.pdf>. Acesso em 02 de janeiro de 2019.

Anuário do Transporte Aéreo 2017. Brasília: ANAC, 2018c. 223 p.

Demanda e Oferta do Transporte Aéreo - Empresas Brasileiras - Dezembro de 2018. Brasília: ANAC, 2019b. 10 p.

ANDRADE, A. C.; SOUZA, U. E. L. Crítica ao processo orçamentário tradicional e recomendações para confecção de um orçamento integrado ao processo de produção de um empreendimento. In: III Simpósio Brasileiro de Gestão e Economia da Construção. Anais. São Carlos. 2003.

ASHFORD, N. J. Level of service design concept for airport passenger terminals: a European view. Transportation Planning and Technology, vol. 12, n. 1, pp. 5-21. 1988.

ÁVILA, A. V.; JUNGLES, A. E. Como compor BDI - Controle e orçamento gerencial na engenharia. Florianópolis, 2001.

BALBO, J. T. Pavimentação Asfáltica: materiais, projetos e restauração. São Paulo: Oficina de Textos, 2007, $558 \mathrm{p}$.

BARROS, A. C. S; OLIVEIRA, I. C. L; FERREIRA, P. G. C. Modelo de estimação paramétrica: uma proposta utilizando modelos ADL e o pacote glmulti. Working Paper - Portal 
Instituto Brasileiro de Economia - Fundação Getúlio Vargas. São Paulo: 2016. Disponível em: $<$ http://portalibre.fgv.br/lumis/portal/file/fileDownload.jsp?fileld=8A7C82C5557F25F201564B E70E4A3C7B>. Acesso em 28 de dezembro de 2018.

BERNUCCI, L. B.; MOTTA, L. M. G.; CERATTI, J. A. P.; SOARES, J. B. Pavimentação asfáltica: formação básica para engenheiros. Rio de Janeiro: PETROBRAS: ABEDA, 2008, $504 \mathrm{f}$.

BOEING COMMERCIAL AIRPLANES. Portal. 2018. Disponível em: $<$ https://www.boeing.com/commercial/>. Acesso em 07 de dezembro de 2018.

BRASIL. Departamento Nacional de Infraestrutura de Transportes. Ministério dos Transportes. Manual de pavimentos rígidos. 2. ed. Rio de Janeiro: Instituto de Pesquisas Rodoviárias, 2004, 233 p.

BRASIL. Secretaria Nacional de Aviação Civil. Ministério dos Transportes, Portos e Aviação Civil. Aviação Regional Conectando o Brasil. 2015a. Disponível em: <http://www.aviacao.gov.br/noticias/2015/01/programa-de-desenvolvimento-aviacaoregional-quer-democratizar-o-transporte-aereo-no-brasil-1/aviacao-regional-versao-site-v4final.pdf>. Acesso em 03 de julho de 2017.

Projeção de demanda da aviação civil: passageiros, aeronaves e carga - 20172037. Brasília: MTPAC, set., 2017, 104 p.

Perspectivas do setor. 2015b. Disponível em: < http://infraestrutura.gov.br/publicacoes-politica-e-planejamento-de-transportes.html>. Acesso em 03 de janeiro de 2019.

CAPES - COORDENAÇÃO DE APERFEIÇOAMENTO DE PESSOAL DE NÍVEL SUPERIOR. Mestrado Profissional: o que é. Brasília: CAPES, 2014. Disponível em: $<$ http://capes.gov.br/avaliacao/sobre-a-avaliacao/mestrado-profissional-o-que-e >. Acesso em 20 de dezembro de 2018.

CARDOSO, L. R. A.; ABIKO, A. K. Metodologia de avaliação de custos de inovações tecnológicas na produção de habitações de interesse social. BT/PCC/249, São Paulo, 2000. $22 \mathrm{p}$.

CARR, R. I. Cost-Estimating Principles. In: Journal of Construction Engineering and Management, v. 115, 4., 1989, American Society of Civil Engineers (ASCE), 1989. pp. 545551.

CAVALEIRO, O. G. Nível de serviço percebido para sala de embarque de aeroportos regionais. 2017. 119 f. Dissertação (Mestrado) - Instituto Tecnológico de Aeronáutica, São José dos Campos, 2017.

CHALTON, N.; MacARDLE, M. A história da ciência para quem tem pressa. 3. ed. Rio de Janeiro: Valentina, 2017, 200 p.

CIVIL AVIATION AUTHORITY OF SINGAPORE. SINGAPORE GOVERNMENT. Portal. Disponível em: <https://www.caas.gov.sg/>. Acesso em 02 de março de 2018.

COOK, G. N.; GOODWIN, J. Airline networks: a comparison of hub-and-spoke and point-topoint systems. Journal of Aviation / Aerospace Education \& Research, v. 17, n. 2, pp. 5160, 2008. 
DECEA - DEPARTAMENTO DE CONTROLE DO ESPAÇO AÉREO. Aeronautical Information Publication - BRASIL. 2019. Disponível em: $<$ https://www.aisweb.aer.mil.br/?i=publicacoes\&p=aip >. Acesso em 10 de fevereiro de 2019.

DURAN, J. B. C. Sistema de gerência de pavimentos aeroportuários: estudo de caso no Aeroporto Estadual de Araraquara. 2015. 204 f. Dissertação (Mestrado). Escola de Engenharia de São Carlo, Universidade de São Paulo, São Carlos, 2015.

DYSERT, L. R. An Introduction to Parametric Estimating. AACE International Transactions, est. 03, 2008.

EASTMAN, C.; TEICHOLZ, P.; SACKS, R.; LISTON, K. Manual de BIM: um guia de modelagem da informação da construção para arquitetos, engenheiros, gerentes, construtores e incorporadores. 1. ed. Porto Alegre: Bookman, 2013, 500 p.

ECK, D.; BRUNDICK, B.; FETTING, T.; DECHORETZ, J.; UGLIJESA, J. Parametric estimating handbook. The International Society of Parametric Analysis. 2009.

EMBRAER - EMPRESA BRASILEIRA DE AERONÁUTICA. Portal. 2019. Disponível em: $<$ https://www.embraercommercialaviation.com/commercial-jets/e195/>. Acesso em 07 de fevereiro de 2019.

FAA - FEDERAL AVIATION ADMINISTRATION. UNITED STATES OF AMERICA. Department of Transportation. Advisory Circular 150-5370-10G - Subject: Standards for Specifying Construction of Airports. Washington, D.C.: FAA, 2014. Disponível em: $<$ https://www.faa.gov/documentLibrary/media/Advisory_Circular/AC-150-5370-10G-updated201605.pdf>. Acesso em 02 de julho de 2018.

Advisory Circular AC 150-5320-6F - Subject: Airport Pavement Design and Evaluation. Washington, D.C.: FAA, 2016. Disponível em: $<$ https://www.faa.gov/documentLibrary/media/Advisory_Circular/AC-150-5370-6F-updated201605.pdf>. Acesso em 02 de julho de 2018.

Advisory Circular AC 150-5325-4B - Subject: Runway Length Requirements for

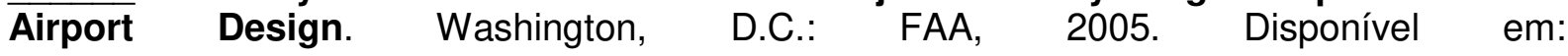
<https://www.faa.gov/documentLibrary/media/Advisory_Circular/AC_150_5325-4B.pdf>. Acesso em 02 de julho de 2018. $<$ https://www.faa.gov/airports/resources/advisory_circulars/index.cfm/go/document.current/d ocumentNumber/150_5360-13>. Acesso em 01 de fevereiro de 2020.

FERNANDES, E.; PACHECO, R. R. Transporte aéreo no Brasil: uma visão de mercado. 1. ed. Rio de Janeiro: Elsevier, 2016, 328 p.

FONSECA O. A. Manutenção de Pavimentos de Aeroportos. Diretoria de Engenharia da Aeronáutica. Divisão de Estudos e Projetos de Infraestrutura. Ministério da Aeronáutica. Brasília, 1990.

FRANCHI, C. C. Avaliação das características que contribuem para a formação do valor de apartamentos na cidade de Porto Alegre. 1991. 131 f. Dissertação (Mestrado) Universidade Federal do Rio Grande do Sul, Porto Alegre, 1991. 
FREITAS, A. K. Análise e aplicação do método do valor agregado no controle de prazos e custos em obras de loteamentos urbanos residenciais. 2017. 89 p. Dissertação (Mestrado) - Escola Politécnica, Universidade de São Paulo, São Paulo, 2017.

FUNARO, V. M. B. O.; PESTANA, M. C.; DZIABAS, M. C. C.; GARCIA, E. M.; SANTOS, M. F.; NASCIMENTO, M. M.; CARDOSO, S. C. Diretrizes para apresentação de dissertações e teses da USP: parte I (ABNT). 3. ed. rev. ampl. mod. - São Paulo: SIBiUSP, 2016. 100 p.

GAN, V. J. L.; WONG, C. L.; TSE, K. T.; CHENG, J. C. P.; LO, I. M. C.; CHAN, C. M. Parametric modelling and evolutionary optimization for cost-optimal and low-carbon design of high-rise reinforced concrete buildings. Advanced Engineering Informatics. Elsevier, vol. 42. 2019.

GIL, A. C. Como elaborar projetos de pesquisa. 4. ed. São Paulo: Atlas, 2008, 175 p.

GONÇALVES, C. M. M. Método para gestão do custo da construção no processo de projeto de edificações. 2011. 182 f. Dissertação (Mestrado). Escola Politécnica, Universidade de São Paulo, São Paulo, 2011.

GOOGLE MAPS. Disponível em: <https://www.google.com.br/maps/>. Acesso em 02 de fevereiro de 2019.

GRAÇA, M. E. A.; GONÇALVES, O. M. Estimação probabilística de custos - Método simplificado. Simpósio sobre Barateamento da Construção Habitacional. Trabalho n. 50. Salvador, 1978.

HIROTA, E. H. Estudo exploratório sobre a tipificação de projetos de edificações, visando a reformulação da Norma Brasileira NB-140/65. 1987. 151 p. Dissertação (Mestrado). Universidade Federal do Rio Grande do Sul, Porto Alegre, 1987.

HORONJEFF, R.; MCKELVEY, F. X.; SPROULE, W. J.; YOUNG, S. B. Planning and design of airports. New York: McGraw-Hill, 5th ed., 2010, 670 p.

INOUYE, L. K. Proposição de um método para subsidiar o prognóstico de custos de urbanização de conjuntos habitacionais horizontais com base em indicadores físicos. 2009. 313 f. Tese (Doutorado) - Escola Politécnica, Universidade de São Paulo, São Paulo, 2009.

IATA - INTERNATIONAL AIR TRANSPORT ASSOCIATION. Airport Development Reference Manual. 10 ed., Montreal, 2016.

IBGE - INSTITUTO BRASILEIRO DE GEOGRAFIA E ESTATÍSTICA. Atlas geográfico escolar. Rio de Janeiro: IBGE, 6 ed., 2012, 215 p.

ICAO - INTERNATIONAL CIVIL AVIATION ORGANIZATION. Annex 14 to the Convention on International Civil Aviation: Aerodromes, Volume I - Design and Operation. Montreal: ICAO, 4 ed., 2004.

INFRAERO - EMPRESA BRASILEIRA DE INFRAESTRUTURA AEROPORTUÁRIA. Portal. 2019. Disponível em: <http://www4.infraero.gov.br/>. Acesso em 02 de janeiro de 2019.

Relatório Anual 2017. Brasília: INFRAERO, 2018a. 145 p.

Anuário Estatístico Operacional 2017. Brasília: INFRAERO, 2018b. 147 p. 
KARSHENAS, S. Predesign cost estimating method for multistory buildings. Journal of Construction Engineering and Management. v. 110, pp. 79-86, mar. 1984.

KATO, C. S. Método para estimar custos diretos da execução de edifícios: aplicação à alvenaria estrutural. 2013. 159 f. Dissertação (Mestrado) - Escola Politécnica, Universidade de São Paulo, São Paulo, 2013.

KIM, G. H.; AN, S. H.; KANG, K. I. Comparison of construction cost estimating models based on regression analysis, neural networks, and case-based reasoning. Building and Environment, v. 39, pp. 1235-1242, 2004.

LEUSIN, S. Métodos de controle de produção e de produtividade nas edificações. XIII ENEGEP - Encontro Nacional de Engenharia de Produção, anais, p. 748-753. Associação Brasileira de Engenharia de Produção - Universidade Federal de Santa Catarina, Florianópolis, out. 1993.

LI, F; XIANYI, G; XIN, M. On reasons of uncontrollable construction cost based on the ABC analysis method and the complete decomposition model. Systems Engineering Procedia, v. 4, pp. 359-365, 2012.

LICHTENBERG, S. The principles of sucessive planning. The Technical University of Denmark, Lyngby, 1980.

LIMA, J. L. P. Custos na construção civil. 2000. 86 p. Dissertação (Mestrado) Universidade Federal Fluminense. Niterói, 2000.

LOSSO, I. R. Utilização das características geométricas da edificação na elaboração de estimativas preliminares de custo: estudo de caso em uma empresa de construção. 1995. 146 p. Dissertação (Mestrado) - Universidade Federal de Santa Catarina. Florianópolis, 1995.

MARCHIORI, F. F. Desenvolvimento de um modelo de redes de composições de custo para orçamentação de obras de edificações. 2009. 235 p. Tese (Doutorado). Escola Politécnica - Universidade de São Paulo. São Paulo, 2009.

MARCONI, M. A; LAKATOS, E. M. Fundamentos de Metodologia Científica. 5. ed. São Paulo: Atlas, 2003, $311 \mathrm{p}$.

MASCARÓ, J. L. O Custo das Decisões Arquitetônicas. 2 ed., Porto Alegre, 1998, 180 p.

MATTOS, A. D. Como preparar orçamentos de obras. São Paulo: PINI, 2006.

MATTOS, A. D. As cinco metodologias de estimar custos. PINI blogs, 2015. Disponível em: $\quad<$ http://blogs.pini.com.br/posts/Engenharia-custos/as-cinco-metodologias-de-estimarcustos-338016-1.aspx>. Acesso em 14 de janeiro de 2019.

MEDEIROS, A. G. M. Um método para dimensionamento de terminais de passageiros em aeroportos brasileiros. 2004. Vol. I - 209 f. Dissertação (Mestrado) - Instituto Tecnológico de Aeronáutica, São José dos Campos, 2004.

MELHADO, S. B.; AGOPYAN, V. O conceito de projeto na construção de edifícios: Diretrizes para a sua elaboração e controle. São Paulo, 1995. Boletim Técnico da Escola Politécnica da USP - Departamento de Engenharia de Construção Civil.

MERMOZ, J. Mes Vols. 1 ed., Paris: Flammarion, 1986, 237 p. 
MINGIONE, C. M. Produtividade na montagem de estruturas de aço para edifícios. 2016. 394 p. Dissertação (Mestrado) - Escola Politécnica, Universidade de São Paulo, São Paulo, 2016.

MOREIRA, F. S. Modelo de previsão de custos na fase de estudo de viabilidade para empresas de construção. 2013. 116 p. Dissertação (Mestrado) - Instituto de Tecnologia, Universidade Federal do Pará, Belém, 2013.

NOVAES, A. L.; SOUZA, A. O. Estudo comparativo dos programas de indução ao transporte aéreo regional brasileiro nos governos Dilma Rousseff (2012) e Michel Temer (2016). In: VI Seminário Internacional América Platina. Campo Grande, nov. 2016.

OLIVEIRA, M. Caracterização de prédios habitacionais de Porto Alegre através de variáveis geométricas - uma proposta a partir das técnicas de estimativas preliminares de custo. 1990. 125p. Dissertação (Mestrado) - Universidade Federal do Rio Grande do Sul, Porto Alegre, 1990.

OTERO, J. A. Análise paramétrica de dados orçamentários para estimativas de custo na construção de edifícios: estudo de caso voltado para a questão da variabilidade. 2000 . 214 f. Dissertação (Mestrado) - Universidade Federal de Santa Catarina, Florianópolis, 2000.

PALIARI, J. C. Metodologia para a coleta e análise de informações sobre consumos e perdas de materiais e componentes nos canteiros de obras de edifícios. 1999. $473 \mathrm{p}$. Dissertação (Mestrado) - Escola Politécnica, Universidade de São Paulo, São Paulo, 1999.

PARISOTTO, J. A. Análise de estimativas paramétricas para formular um modelo de quantificação de serviços, consumo de mão de obra e custos de edificações residenciais: estudo de caso para uma empresa construtora. 2003. $121 \mathrm{f}$. Dissertação (Mestrado) - Universidade Federal de Santa Catarina, Florianópolis, 2003.

PIKETTY, T. O Capital. 1 ed., Rio de Janeiro: Intrínseca, 2014, 672 p.

PMI - PROJECT MANAGEMENT INSTITUT. PMBOK Guide - A guide to the Project Management Body of Knowledge. 6 ed., Belo Horizonte: Project Management Institute, 2018, 756 p.

RIBEIRO, G. Aeroporto Afonso Pena precisa melhorar o sistema de pistas. Gazeta do povo. Curitiba, 02 set. 2014. Disponível em: <https://www.gazetadopovo.com.br/blogs/avioes-emfoco/aeroporto-afonso-pena-precisa-melhorar-o-sistema-de-pistas/>. Acesso em $03 \mathrm{de}$ dezembro de 2018.

RIBEIRO, R. L. Metodologia para avaliação de orçamentos-tipo de edifícios residenciais. 2014. 152 p. Dissertação (Mestrado) - Instituto de Pesquisas Tecnológicas do Estado de São Paulo, São Paulo, 2014.

ROCHA LIMA, J. Formação de modelos para análise econômico-financeiras na construção civil. 1985. Tese (Doutorado) - Escola Politécnica, Universidade de São Paulo, São Paulo, 1985.

SANTOS, N. M. Orçamentação na construção civil. Revista Especialize On-line IPOG, v. 01, n. 10, pp. 1-15, dez. 2015.

SEIL/PR - SECRETARIA DE ESTADO DE INSFRAESTRUTURA E LOGÍSTICA DO PARANÁ. Relatório Final - Volume III - Assistência na revisão e atualização do plano aeroviário estadual do Paraná. dez. 2014. Disponível em: < 
http://www.infraestrutura.pr.gov.br/arquivos/File/plano\%20aero/RelatorioFinalVolume3.pdf>. Acesso em 06 de setembro de 2019.

SILVESTRI, A. L. S. Termo de referência para gestão de projetos arquitetônicos de terminais aeroportuários regionais de passageiros. 2015. 264 p. Tese (Doutorado) Instituto de Arquitetura e Urbanismo - Universidade de São Paulo, São Carlos, 2015.

SINAPI - SISTEMA NACIONAL DE PESQUISA DE CUSTOS E ÍNDICES DA CONSTRUÇÃO CIVIL. jul. 2018. Disponível em: <http://www.caixa.gov.br/poder-publico/apoio-poderpublico/sinapi/Paginas/default.aspx>. Acesso em 11 de agosto de 2018.

Custos de composições analítico. 2015a. Sistema Nacional de Pesquisa de Custos e Índices da Construção Civil da Caixa Econômica Federal.

Manual de Metodologias e Conceitos. Versão 005. 2015b. Sistema Nacional de Pesquisa de Custos e Índices da Construção Civil da Caixa Econômica Federal.

SOUZA, U. E. L. Como aumentar a eficiência da mão de obra. 1. ed. São Paulo: Pini, 2006, $100 \mathrm{p}$.

TCU - TRIBUNAL DE CONTAS DA UNIÃO. Relatório de Fiscalização Sintético - Obras de Construção do novo aeroporto de Florianópolis. 2014. Disponível em: < https://www.camara.leg.br/internet/comissao/index/mista/orca/orcamento/OR2015/Fiscobras 2014/anexo/SINTETICOS/Sint\%C3\%A9tico_2014_473.pdf>. Acesso em 06 de setembro de 2019.

UGUR, L. O.; KANIT, R.; ERDAL, H.; NAMLI, E.; ERDAL, H. I.; BAYKAN, U. N.; ERDAL, M. Enhanced predictive models for construction costs: a case study of Turkish mass housing sector. Computacional Economics, v. 53, n. 4, pp. 1403-1419, apr.2019.

UNITED STATES OF AMERICA. Department of Defense. Parametric Cost Estimating Handbook. 1995. 260 p.

National Aeronautics and Space Administration. NASA Cost Estimating Handbook Version 4.0. 2015. 63 p. Disponível em: <https://www.nasa.gov/pdf/263676main_2008NASA-Cost-Handbook-FINAL_v6.pdf>. Acesso em 08 de maio de 2018.

VASCONCELOS, L. F. S. O aeroporto como integrante de um projeto de desenvolvimento regional: a experiência brasileira. 2007. 149 f. Dissertação (Mestrado em Transportes) - Departamento de Engenharia Civil e Ambiental, Universidade de Brasília, Brasília, 2007.

VELÁSQUEZ, C. M. G.; CASTAÑEDA, A. S. V.; AGUIRRE, S. Z. Las infraestructuras aeroportuarias: tipo de propiedad y su relación con la eficiencia. Revista Ingenierías Universidad de Medellín, v. 14, n. 27, pp. 179-194, jul./dez., 2015.

VOKÁC, R.; LÁNSKÝ, M.; SZABO, S. The dependence of airport profit on passenger satisfaction and operational efficiency. Magazine of Aviation Development, v. 5, n. 2, pp. 1114, 2017.

YOUNG, S.; WELLS, A. Aeroportos: planejamento e gestão. 6. ed. Porto Alegre: Bookman, 2014, 539 p. 


\section{APÊNDICE A}

Caracterização dos aeroportos empregados no desenvolvimento da modelagem, com base em INFRAERO (2019).

\section{Aeroporto Santa Maria - Aracaju/SE}

\section{Figura A-1 - Sítio aeroportuário - Aeroporto} Santa Maria

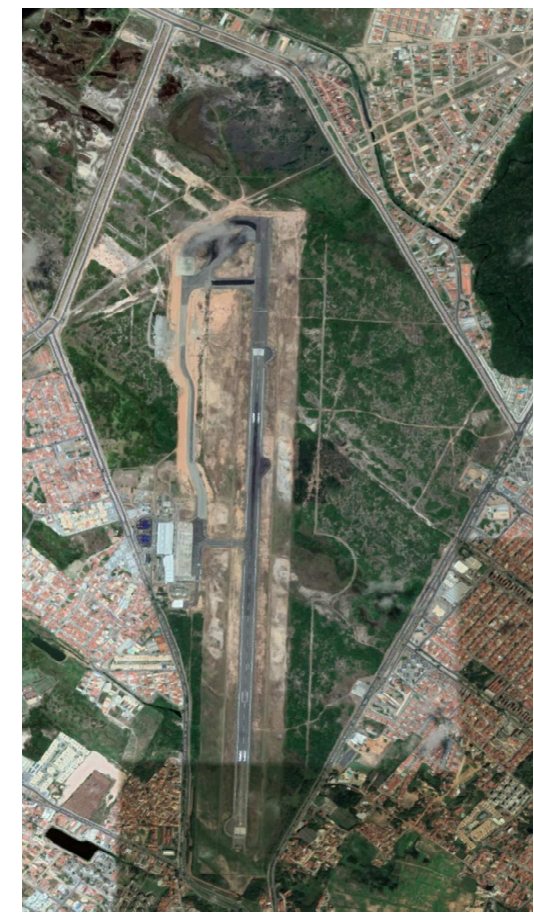

Fonte: GOOGLE MAPS (fev/2019)

\section{Figura A-2 - Carta aeronáutica do Aeroporto} Santa Maria

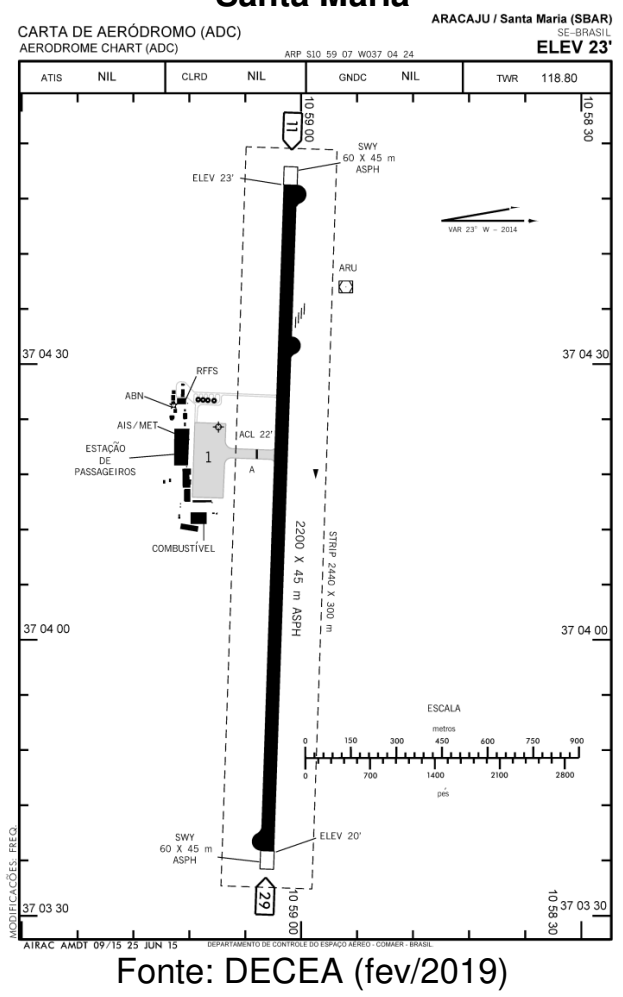

Designativo ICAO: SBAR; Capacidade de atendimento: 2.600 .000 passageiros/ano; Demanda atendida em 2017: 1.194.951 passageiros; PPD: 1 pista, pavimento flexível, dimensões - 2.200 x 45 m; Pátio de estacionamento de aeronaves: $18.000 \mathrm{~m}^{2}$, pavimento rígido. 
2. Aeroporto Internacional Val de Cans / Júlio Cezar Ribeiro - Belém/PA

Figura A-3 - Sítio aeroportuário - Aeroporto Internacional Val de Cans

Figura A-4 - Carta aeronáutica do Aeroporto Internacional Val de Cans

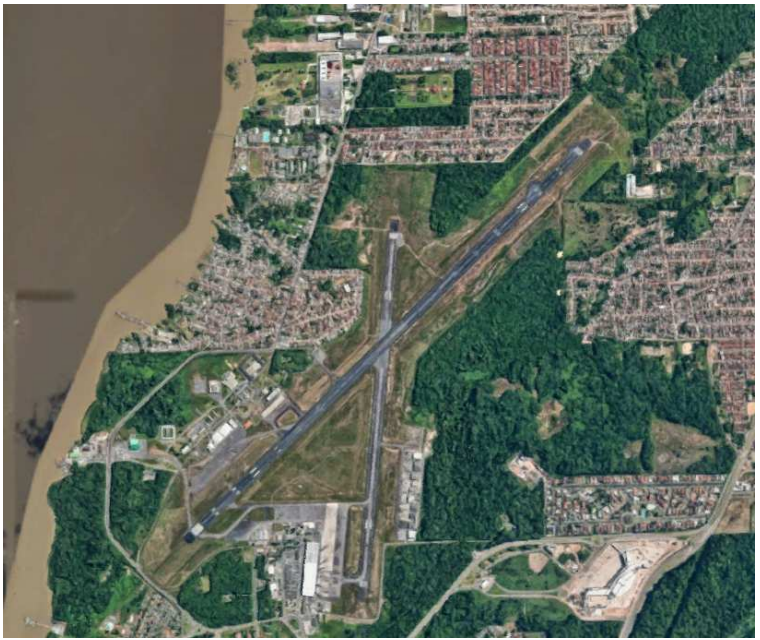

Fonte: GOOGLE MAPS (fev/2019)

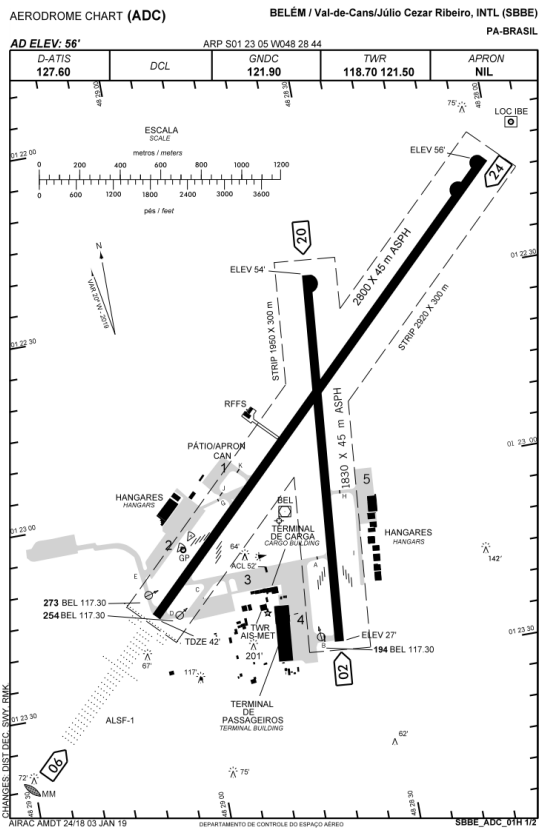

Fonte: DECEA (fev/2019)

Designativo ICAO: SBBE; Capacidade de atendimento: 7.700 .000 passageiros/ano; Demanda atendida em 2017: 3.215.144 passageiros; PPD: 2 pistas, pavimento flexível, dimensões da pista principal - 2.800 x $45 \mathrm{~m}$; Pátio de estacionamento de aeronaves: $50.000 \mathrm{~m}^{2}$, pavimento rígido.

\section{Aeroporto Internacional de Campo Grande - Campo Grande/MS}

\section{Figura A-5 - Sítio aeroportuário - Aeroporto} Internacional de Campo Grande

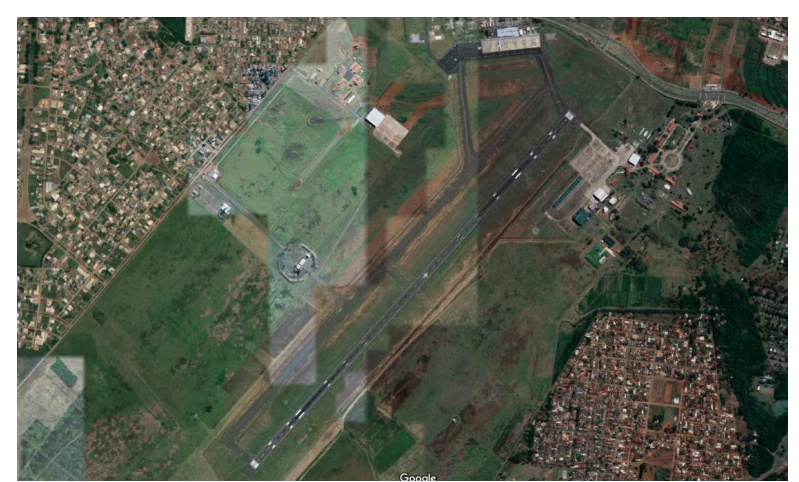

Fonte: GOOGLE MAPS (fev/2019)
Figura A-6 - Carta aeronáutica do Aeroporto Internacional de Campo Grande

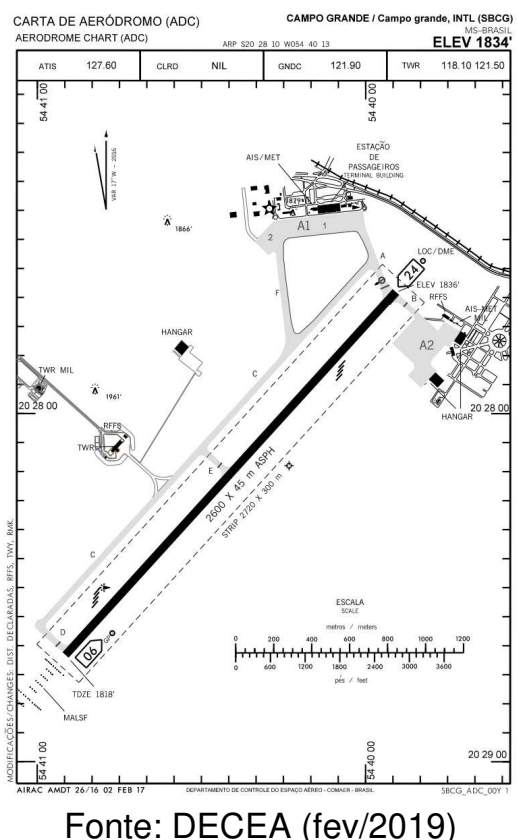

Fonte: DECEA (fev/2019)

Designativo ICAO: SBCG; Capacidade de atendimento: 1.600 .000 passageiros/ano; Demanda atendida em 2017: 1.508.399 passageiros; PPD: 1 pista, pavimento flexível, dimensões: 2.600 x 45 m; Pátio de estacionamento de aeronaves: $25.000 \mathrm{~m}^{2}$, pavimento rígido. 


\section{Aeroporto Internacional Afonso Pena - Curitiba/PR}

Figura A-7 - Sítio aeroportuário - Aeroporto Internacional Afonso Pena

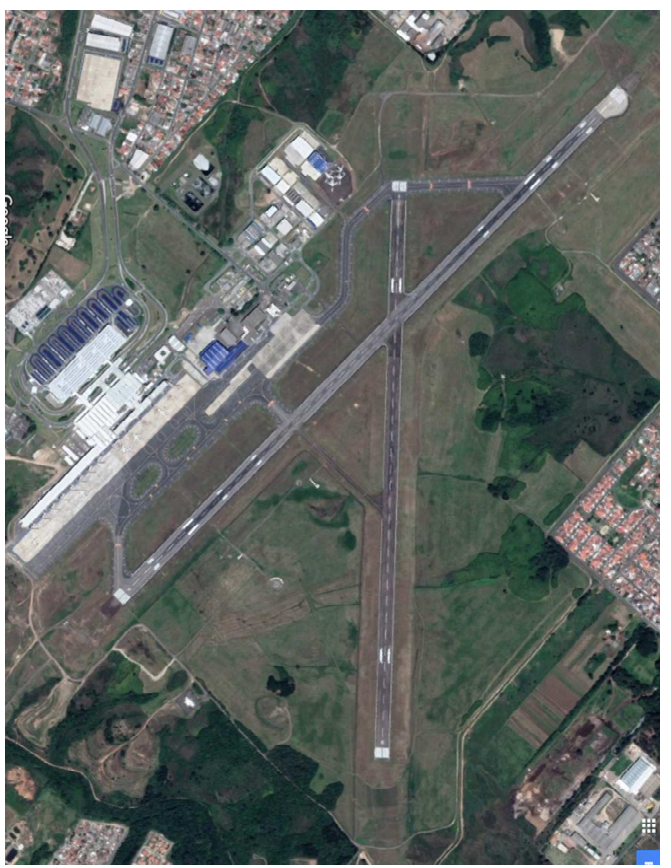

Fonte: GOOGLE MAPS (fev/2019)
Figura A-8 - Carta aeronáutica do Aeroporto Internacional Afonso Pena

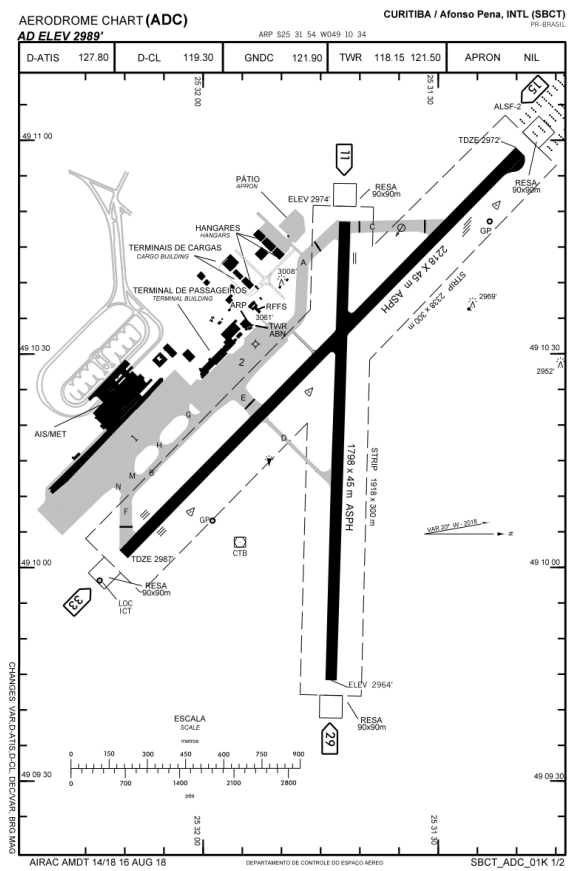

Fonte: DECEA (fev/2019)

Designativo ICAO: SBCT; Capacidade de atendimento: 14.800 .000 passageiros/ano; Demanda atendida em 2017: 6.400 .794 passageiros; PPD: 2 pistas, pavimento flexível, dimensões: 2.218 x 45 m; Pátio de estacionamento de aeronaves: $90.000 \mathrm{~m}^{2}$, pavimento rígido.

\section{Aeroporto Internacional Marechal Rondon - Cuiabá/MT}

Figura A-9 - Sítio aeroportuário - Aeroporto Internacional Marechal Rondon

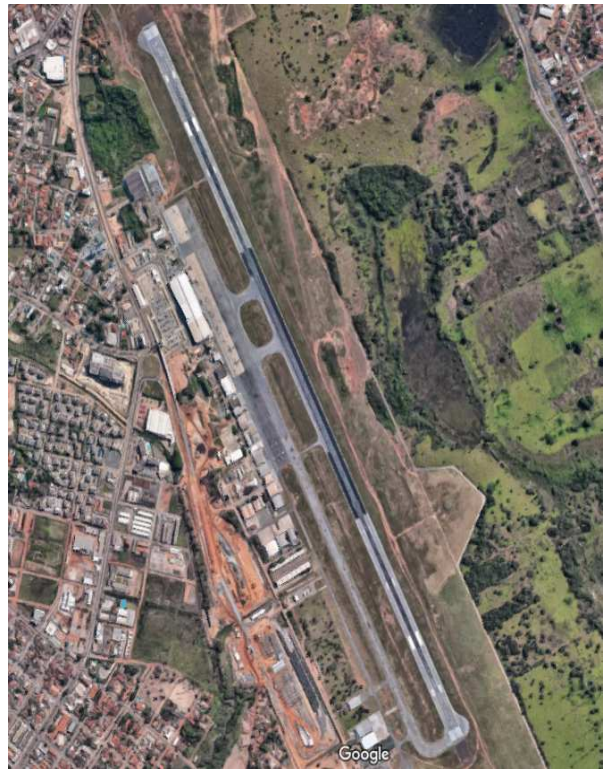

Fonte: GOOGLE MAPS (fev/2019)
Figura A-10 - Carta aeronáutica do Aeroporto Internacional Marechal Rondon

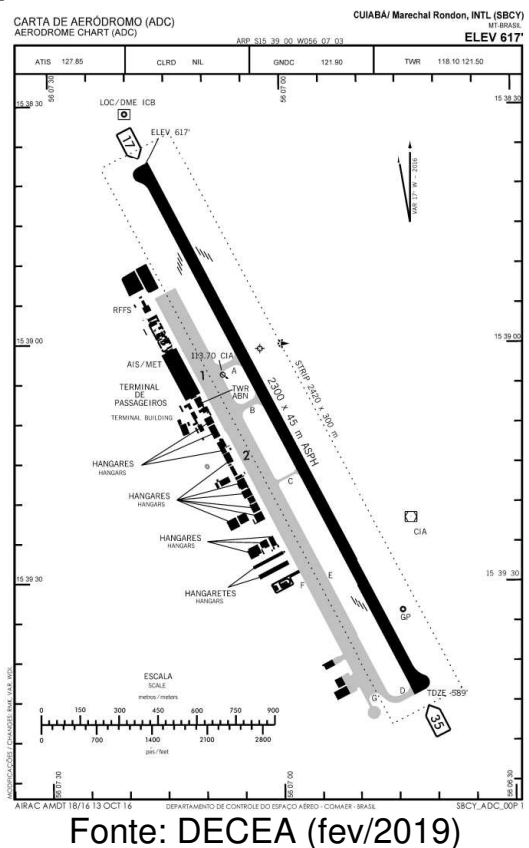

Designativo ICAO: SBCY; Capacidade de atendimento: 5.700.000 passageiros/ano; Demanda atendida em 2017: 2.791.831 passageiros; PPD: 1 pista, pavimento flexível - revestimento asfáltico, dimensões - 2.300 x 45 m; Pátio de estacionamento de aeronaves: $50.000 \mathrm{~m}^{2}$, pavimento rígido. 


\section{Aeroporto Internacional Eduardo Gomes - Manaus/AM}

Figura A-11 - Sítio aeroportuário - Aeroporto Internacional Eduardo Gomes

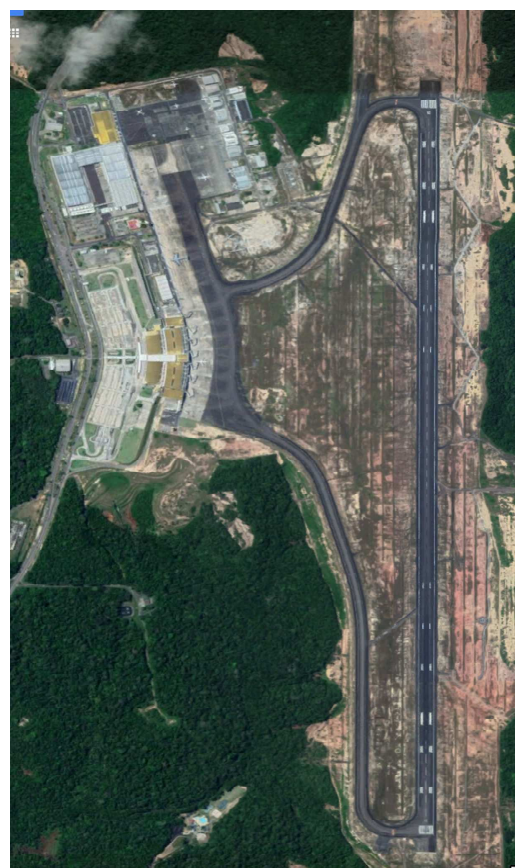

Fonte: GOOGLE MAPS (fev/2019)
Figura A-12 - Carta aeronáutica do Aeroporto Internacional Eduardo Gomes

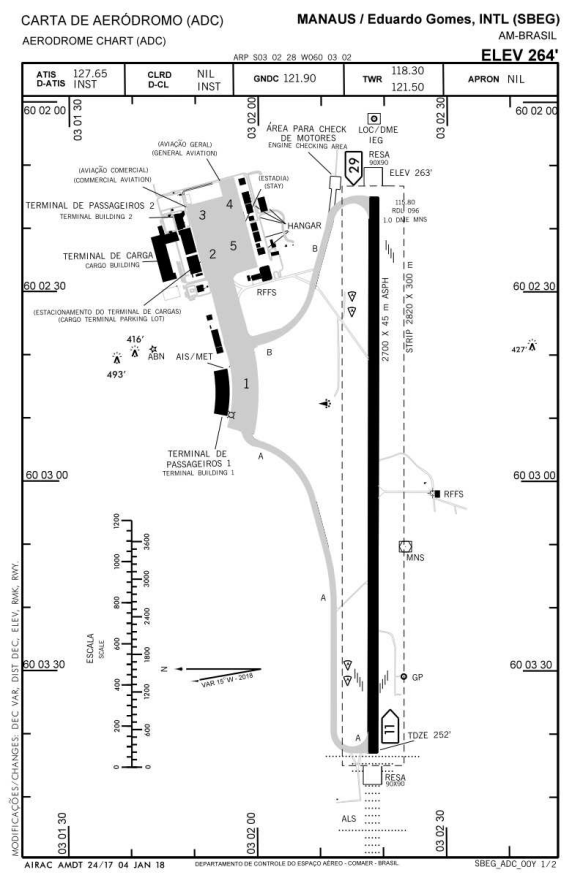

Fonte: DECEA (fev/2019)

Designativo ICAO: SBEG; Capacidade de atendimento: 18.200 .000 passageiros/ano; Demanda atendida em 2017: 2.486.028 passageiros; PPD: 1 pista, pavimento, dimensões - 2.700 × 45 m; Pátio de estacionamento de aeronaves: $80.000 \mathrm{~m}^{2}$, pavimento rígido.

\section{Aeroporto Internacional Cataratas - Foz do Iguaçu/PR}

\section{Figura A-13 - Sítio aeroportuário - Aeroporto Internacional Cataratas}

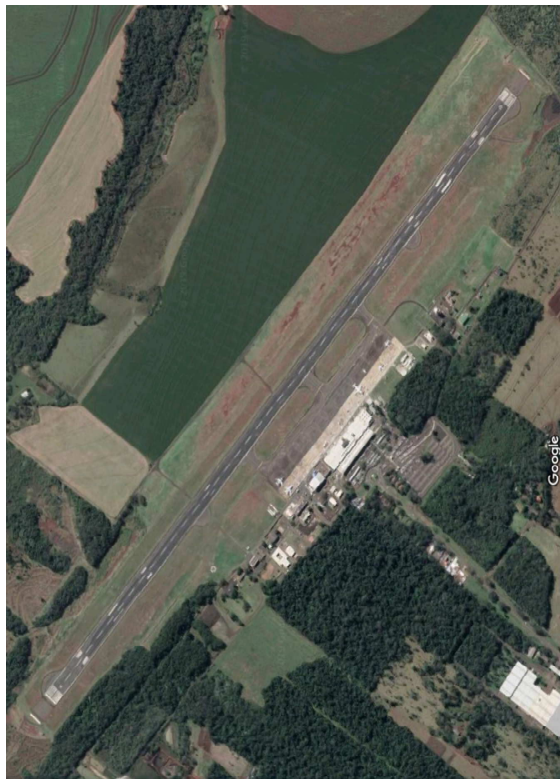

Fonte: GOOGLE MAPS (fev/2019)
Figura A-14 - Carta aeronáutica do Aeroporto Internacional Cataratas

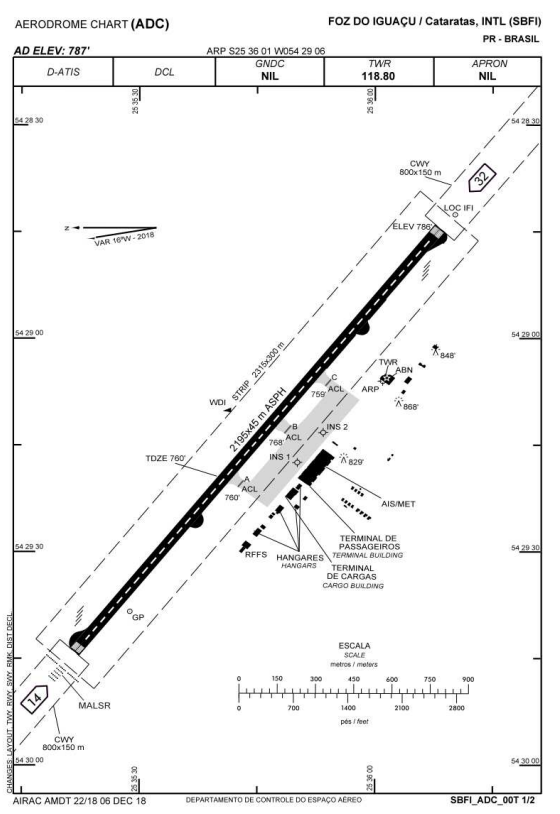

Fonte: DECEA (fev/2019)

Designativo ICAO: SBFI; Capacidade de atendimento: 2.800 .000 passageiros/ano; Demanda atendida em 2017: 1.996.823 passageiros; PPD: 1 pista, pavimento flexível, dimensões - 2.195 x 45 m; Pátio de estacionamento de aeronaves: $35.000 \mathrm{~m}^{2}$, pavimento rígido. 
8. Aeroporto Santa Genoveva - Goiânia/GO

\section{Figura A-15 - Sítio aeroportuário - Aeroporto Santa Genoveva}

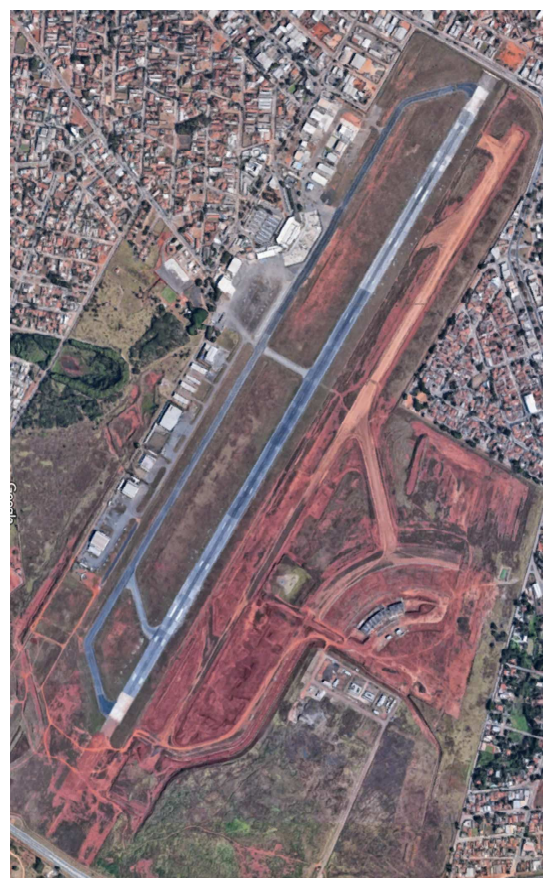

Fonte: GOOGLE MAPS (fev/2019)
Figura A-16 - Carta aeronáutica do Aeroporto Santa Genoveva

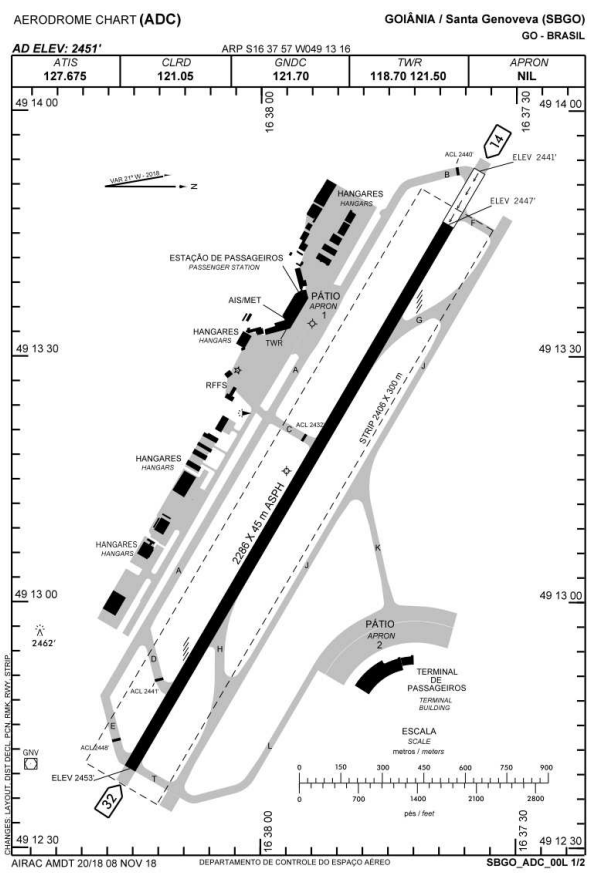

Fonte: DECEA (fev/2019)

Designativo ICAO: SBGO; Capacidade de atendimento: 6.300 .000 passageiros/ano; Demanda atendida em 2017: 2.905.906 passageiros; PPD: 1 pista, pavimento flexível, dimensões - 2.286 x 45 m; Pátio de estacionamento de aeronaves: $30.000 \mathrm{~m}^{2}$, pavimento rígido.

\section{Aeroporto Internacional Presidente Castro Pinto - João Pessoa/PB}

Figura A-17 - Sítio aeroportuário - Aeroporto Internacional Presidente Castro Pinto

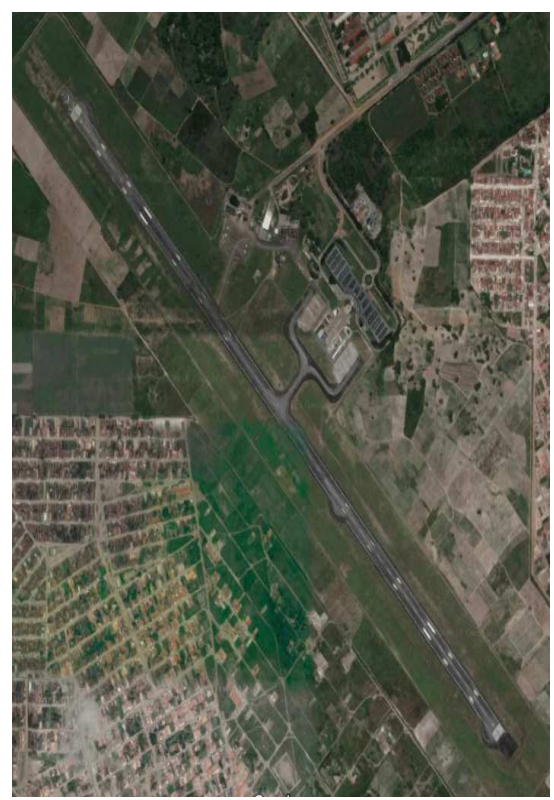

Fonte: GOOGLE MAPS (fev/2019)
Figura A-18 - Carta aeronáutica do Aeroporto Internacional Pres. Castro Pinto

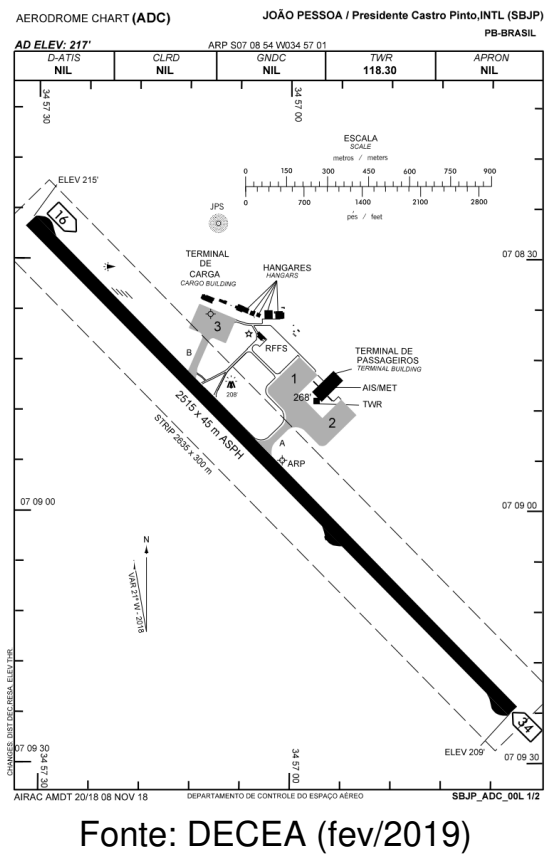

Designativo ICAO: SBJP; Capacidade de atendimento: 2.300 .000 passageiros/ano; Demanda atendida em 2017: 1.379.651 passageiros; PPD: 1 pista, pavimento flexível, dimensões - 2.515 x 45 m; Pátio de estacionamento de aeronaves: $20.000 \mathrm{~m}^{2}$, pavimento rígido. 
10. Aeroporto Orlando Bezerra de Menezes - Juazeiro do Norte/CE

Figura A-19 - Sítio aeroportuário - Aeroporto Orlando Bezerra de Menezes

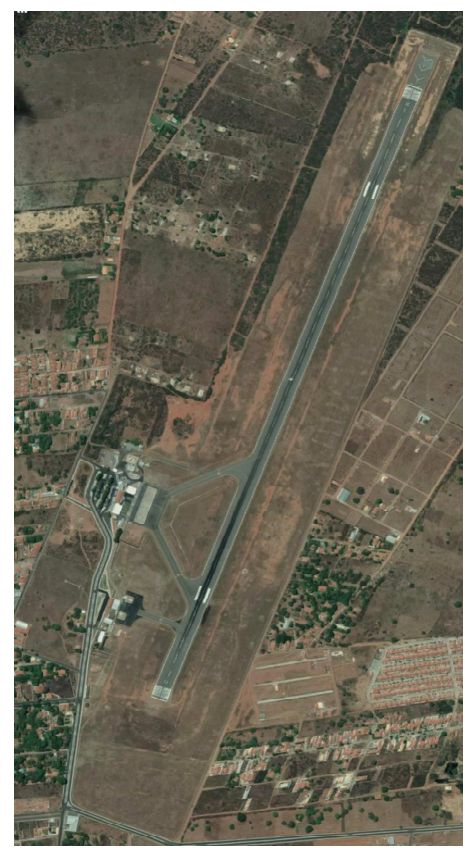

Fonte: GOOGLE MAPS (fev/2019)
Figura A-20 - Carta aeronáutica do Aeroporto Orlando Bezerra de Menezes

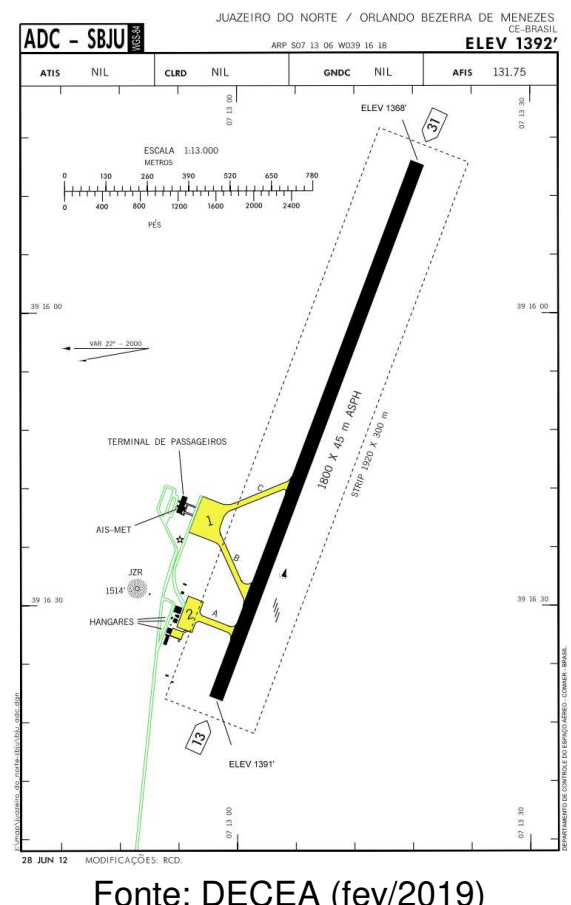

Designativo ICAO: SBJU; Capacidade de atendimento: 1.700 .000 passageiros/ano; Demanda atendida em 2017: 538.971 passageiros; PPD: 1 pista, pavimento flexível, dimensões - 1.800 x 45 m; Pátio de estacionamento de aeronaves: $10.000 \mathrm{~m}^{2}$, pavimento rígido.

\section{Aeroporto Lauro Carneiro de Loyola - Joinville/SC}

\section{Figura A-21 - Sítio aeroportuário - Aeroporto Lauro Carneiro de Loyola}

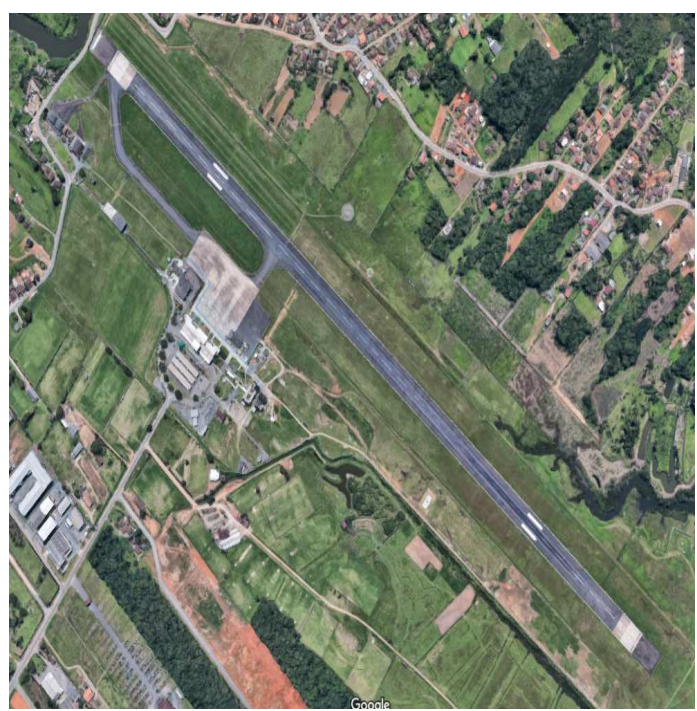

Fonte: GOOGLE MAPS (fev/2019)
Figura A-22 - Carta aeronáutica do Aeroporto Lauro Carneiro de Loyola

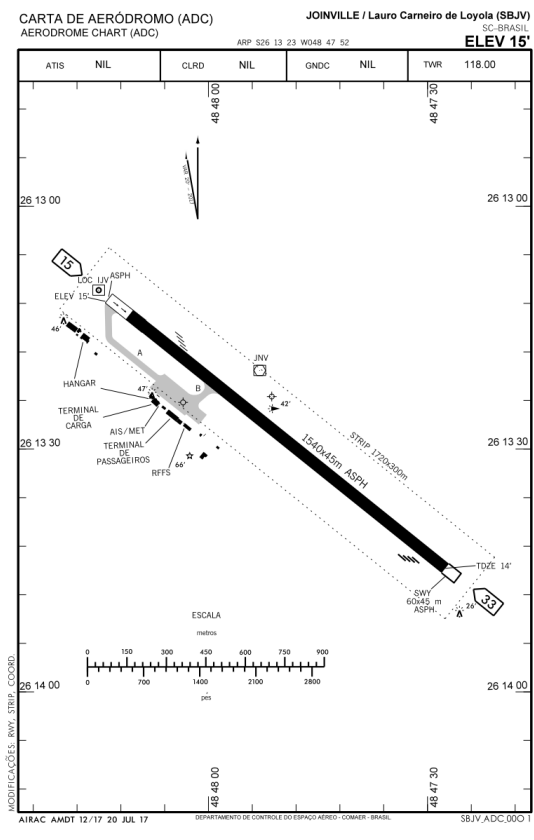

Fonte: DECEA (fev/2019)

Designativo ICAO: SBJV; Capacidade de atendimento: 800.000 passageiros/ano; Demanda atendida em 2017: 468.313 passageiros; PPD: 1 pista, pavimento flexível, dimensões - 1.540 x 45 m; Pátio de estacionamento de aeronaves: $15.000 \mathrm{~m}^{2}$, pavimento rígido. 
12. Aeroporto Governador José Richa - Londrina/PR

Figura A-23 - Sítio aeroportuário - Aeroporto Governador José Richa

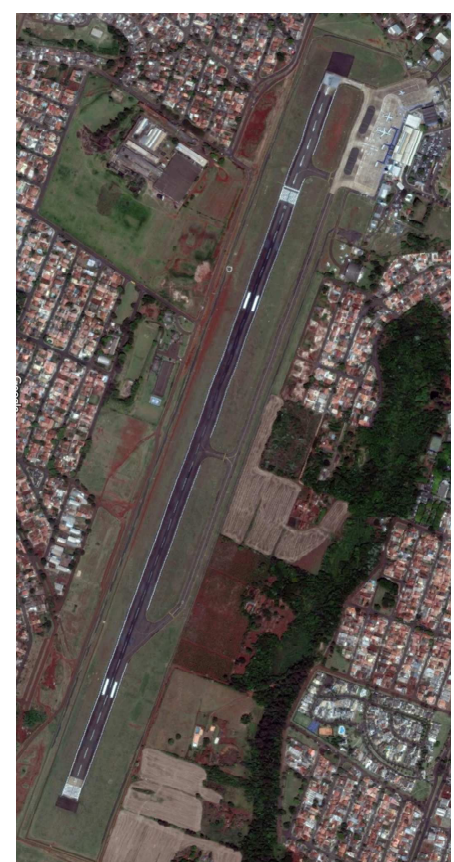

Fonte: GOOGLE MAPS (fev/2019)
Figura A-24 - Carta aeronáutica do Aeroporto Governador José Richa

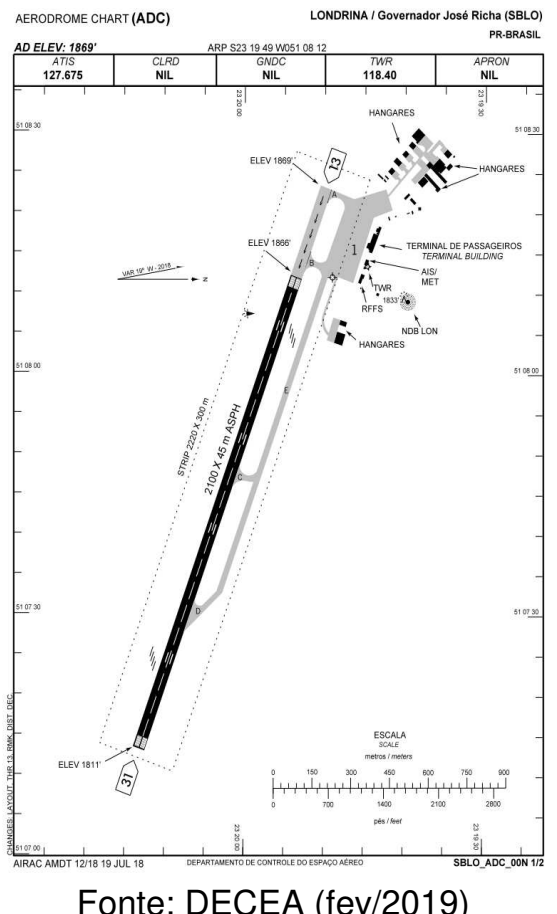

Fonte: DECEA (fev/2019)

Designativo ICAO: SBLO; Capacidade de atendimento: 3.100 .000 passageiros/ano; Demanda atendida em 2017: 800.936 passageiros; PPD: 1 pista, pavimento flexível, dimensões - 2.100 × 45 m; Pátio de estacionamento de aeronaves: $35.000 \mathrm{~m}^{2}$, pavimento rígido.

13. Aeroporto Internacional Zumbi dos Palmares - Maceió/AL

Figura A-25 - Sítio aeroportuário - Aeroporto Internacional Zumbi dos Palmares

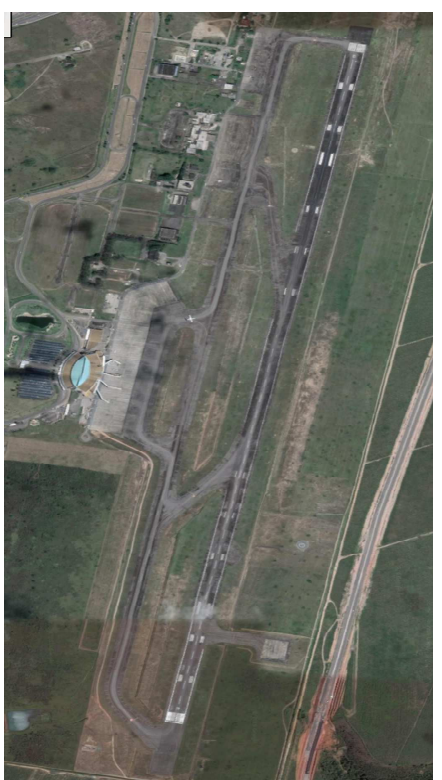

Fonte: GOOGLE MAPS (fev/2019)
Figura A-26 - Carta aeronáutica do Aeroporto Internacional Zumbi dos Palmares

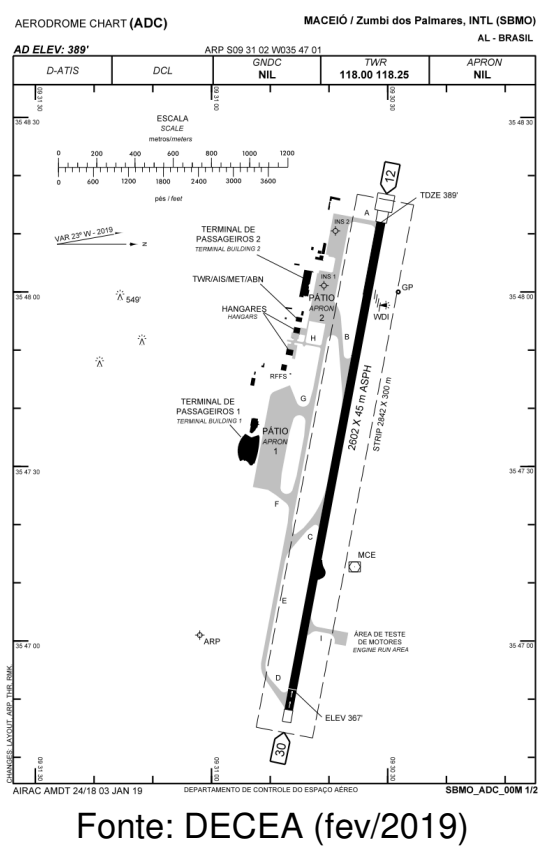

Designativo ICAO: SBMO; Capacidade de atendimento: 5.300 .000 passageiros/ano; Demanda atendida em 2017: 1.894.163 passageiros; PPD: 1 pista, pavimento flexível, dimensões - 2.602 × 45 m; Pátio de estacionamento de aeronaves: $60.000 \mathrm{~m}^{2}$, pavimento. 
14. Aeroporto Internacional Alberto Alcolumbre - Macapá/AP

Figura A-27 - Sítio aeroportuário - Aeroporto Internacional Alberto Alcolumbre

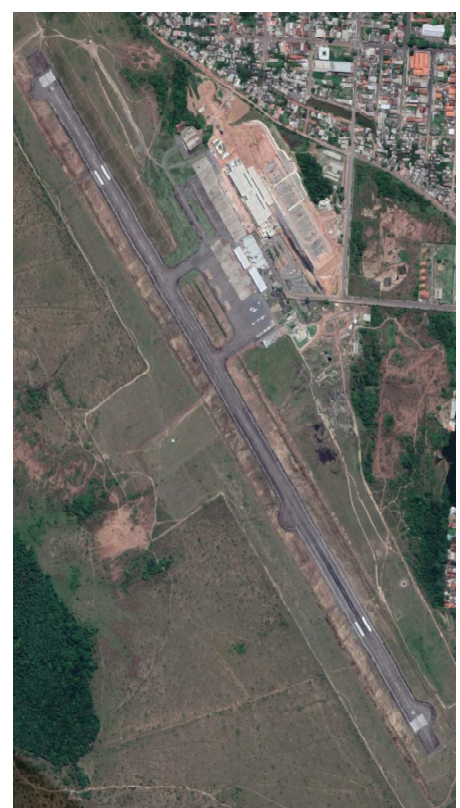

Fonte: GOOGLE MAPS (fev/2019)
Figura A-28 - Carta aeronáutica do Aeroporto Internacional Alberto Alcolumbre

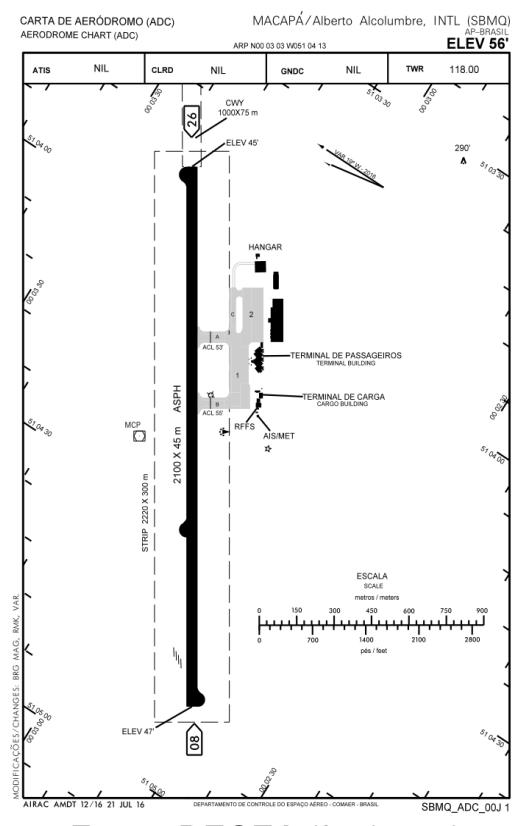

Fonte: DECEA (fev/2019)

Designativo ICAO: SBMQ; Capacidade de atendimento: 2.100 .000 passageiros/ano; Demanda atendida em 2017: 569.899 passageiros; PPD: 1 pista, pavimento flexível, dimensões - 2.100 x 45 m; Pátio de estacionamento de aeronaves: $20.000 \mathrm{~m}^{2}$, pavimento rígido.

\section{Aeroporto Internacional Ministro Victor Konder - Navegantes/SC}

Figura A-29 - Sítio aeroportuário - Aeroporto Internacional Ministro Victor Konder

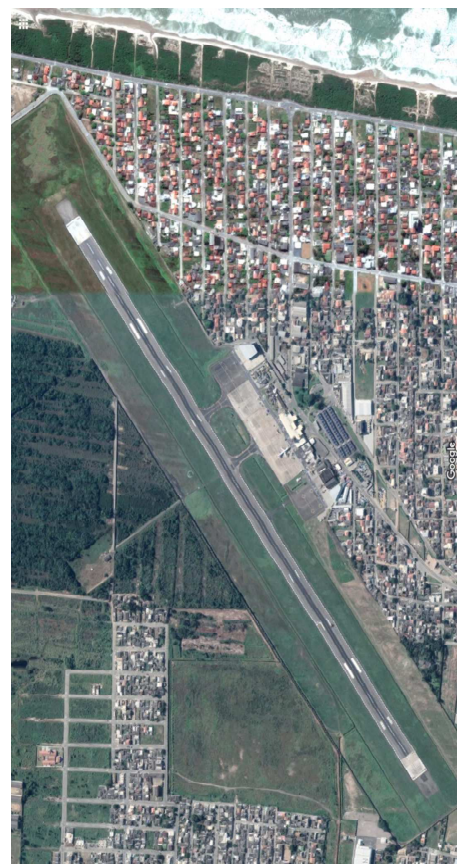

Fonte: GOOGLE MAPS (fev/2019)
Figura A-30 - Carta aeronáutica do Aeroporto Internacional Min. Victor Konder

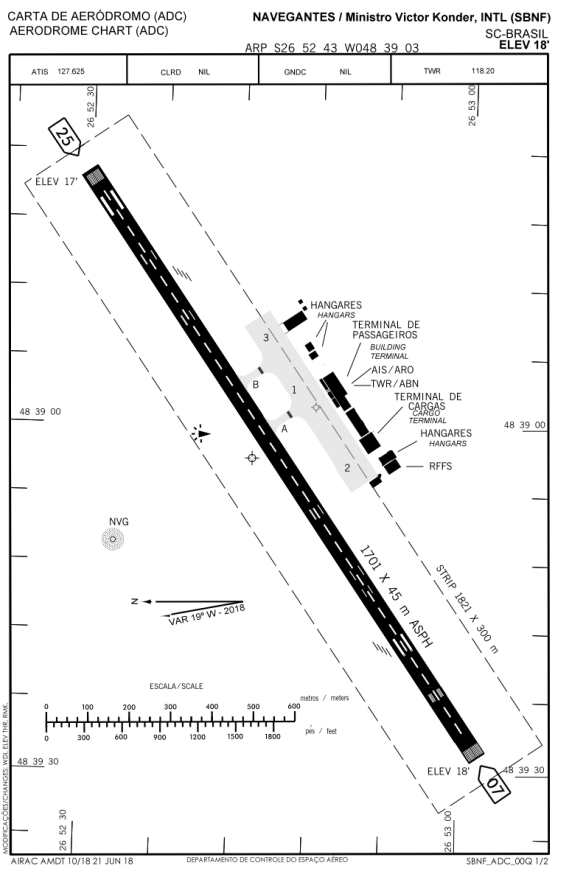

Fonte: DECEA (fev/2019)

Designativo ICAO: SBNF; Capacidade de atendimento: 1.400 .000 passageiros/ano; Demanda atendida em 2017: 1.545.396 passageiros; PPD: 1 pista, pavimento flexível, dimensões - 1.701 x 45 m; Pátio de estacionamento de aeronaves: $22.000 \mathrm{~m}^{2}$, pavimento rígido. 
16. Aeroporto Brigadeiro Lysias Rodrigues - Palmas/TO

Figura A-31 - Sítio aeroportuário - Aeroporto Brigadeiro Lysias Rodrigues

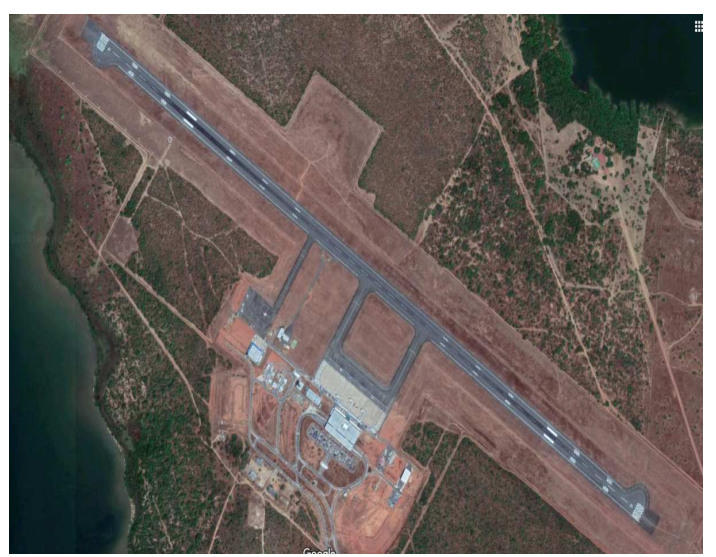

Fonte: GOOGLE MAPS (fev/2019)
Figura A-32 - Carta aeronáutica do Aeroporto Brigadeiro Lysias Rodrigues

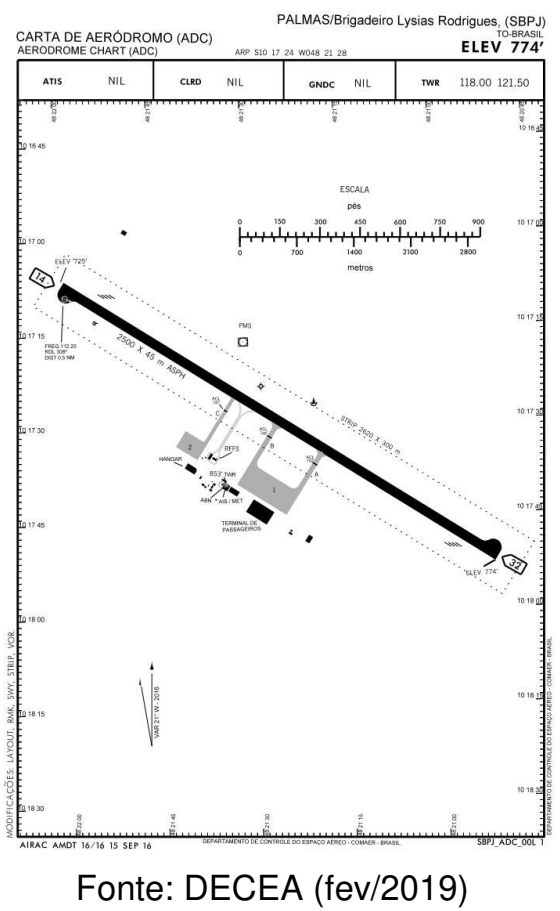

Designativo ICAO: SBPJ; Capacidade de atendimento: 2.100 .000 passageiros/ano; Demanda atendida em 2017: 639.568 passageiros; PPD: 1 pista, pavimento flexível, dimensões - 2.500 × 45 m; Pátio de estacionamento de aeronaves: $24.000 \mathrm{~m}^{2}$, pavimento rígido.

\section{Aeroporto Senador Nilo Coelho - Petrolina/PE}

Figura A-33 - Sítio aeroportuário - Aeroporto Senador Nilo Coelho

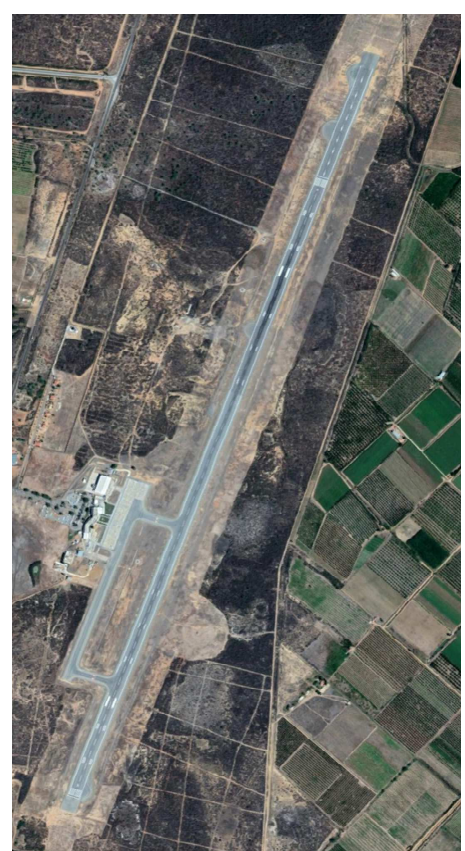

Fonte: GOOGLE MAPS (fev/2019)
Figura A-34 - Carta aeronáutica do Aeroporto Senador Nilo Coelho

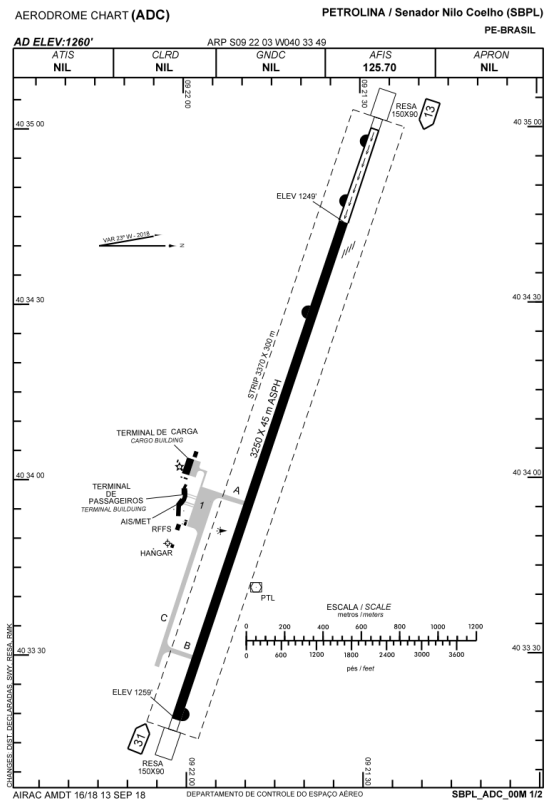

Fonte: DECEA (fev/2019)

Designativo ICAO: SBPL; Capacidade de atendimento: 1.500 .000 passageiros/ano; Demanda atendida em 2017: 472.786 passageiros; PPD: 1 pista, pavimento flexível, dimensões - 3.250 x 45 m; Pátio de estacionamento de aeronaves: $20.000 \mathrm{~m}^{2}$, pavimento rígido. 


\section{Aeroporto Governador Jorge Teixeira de Oliveira - Porto Velho/RO}

Figura A-35 - Sítio aeroportuário - Aeroporto Governador Jorge Teixeira de Oliveira

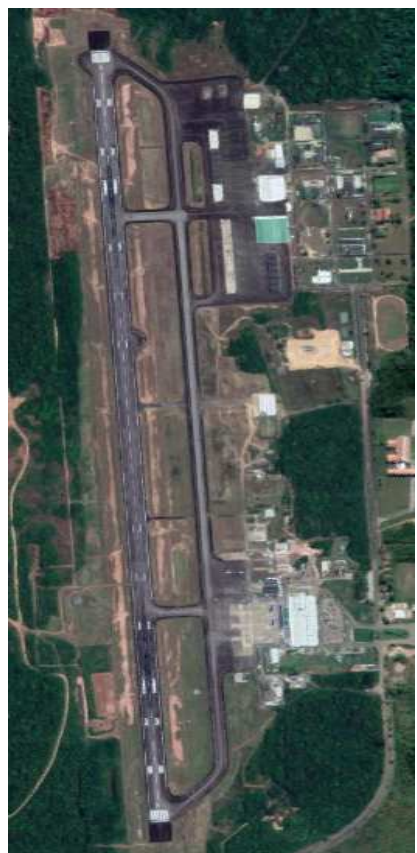

Fonte: GOOGLE MAPS (fev/2019)
Figura A-36 - Carta aeronáutica do Aeroporto Gov. Jorge Teixeira de Oliveira

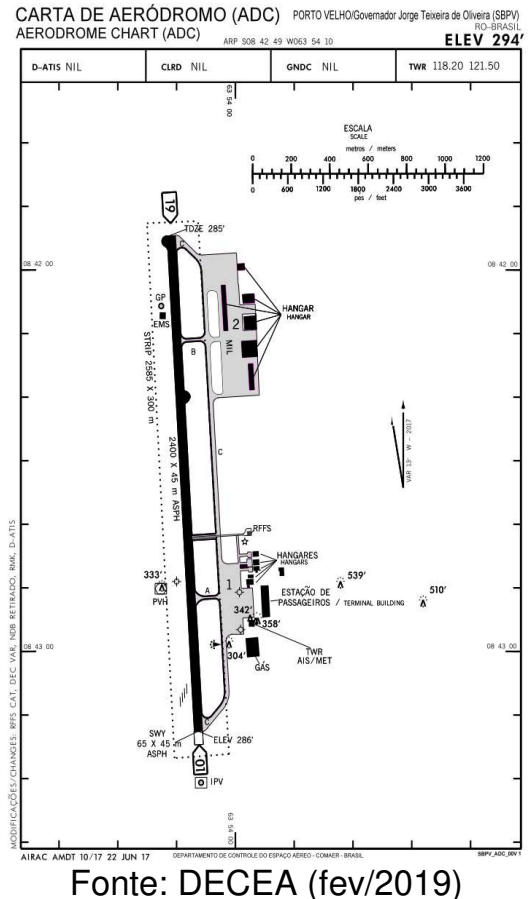

Fonte: DECEA (fev/2019)

Designativo ICAO: SBPV; Capacidade de atendimento: 3.500 .000 passageiros/ano; Demanda atendida em 2017: 791.156 passageiros; PPD: 1 pista, pavimento flexível, dimensões - 2.400 × 45 m; Pátio de estacionamento de aeronaves: $18.000 \mathrm{~m}^{2}$, pavimento rígido.

19. Aeroporto Plácido de Castro - Rio Branco/AC

\section{Figura A-37 - Sítio aeroportuário - Aeroporto Plácido de Castro}

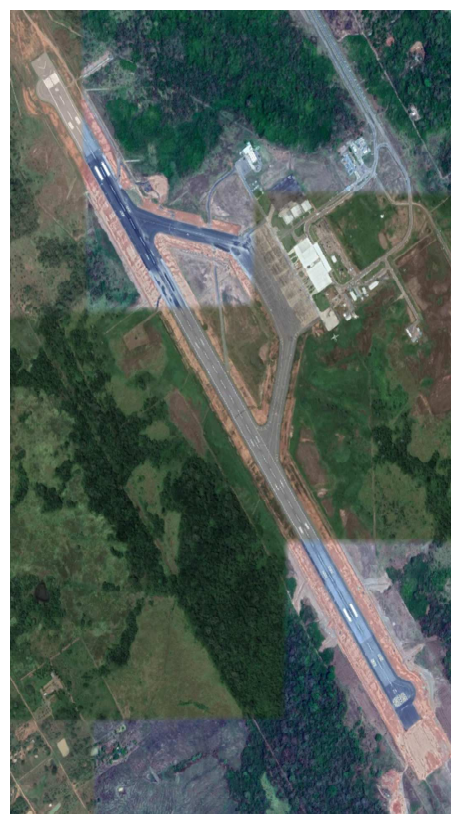

Fonte: GOOGLE MAPS (fev/2019)
Figura A-38 - Carta aeronáutica do Aeroporto Plácido de Castro

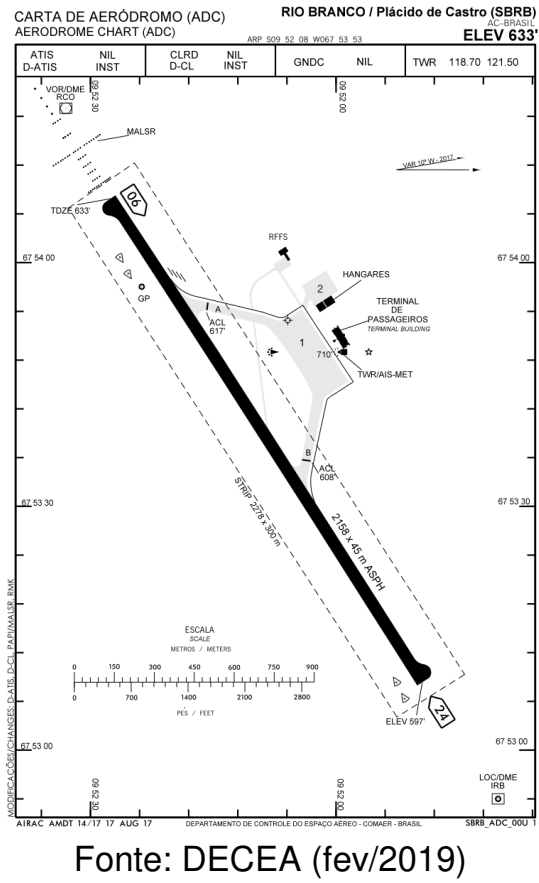

Designativo ICAO: SBRB; Capacidade de atendimento: 1.300 .000 passageiros/ano; Demanda atendida em 2017: 333.128 passageiros; PPD: 1 pista, pavimento flexível, dimensões - 2.158 x 45 m; Pátio de estacionamento de aeronaves: $25.000 \mathrm{~m}^{2}$, pavimento rígido. 


\section{Aeroporto Internacional Guararapes / Gilberto Freire - Recife/PE}

\section{Figura A-39 - Sítio aeroportuário - Aeroporto Internacional Guararapes}

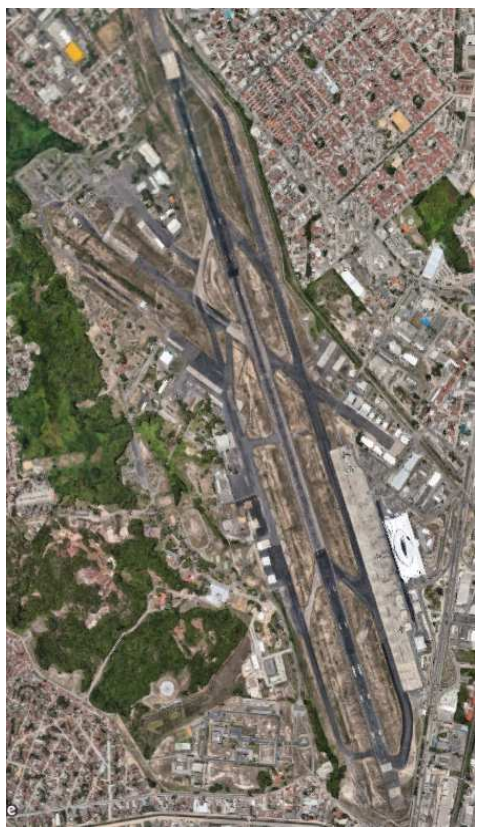

Fonte: GOOGLE MAPS (fev/2019)
Figura A-40 - Carta aeronáutica do Aeroporto Internacional Guararapes

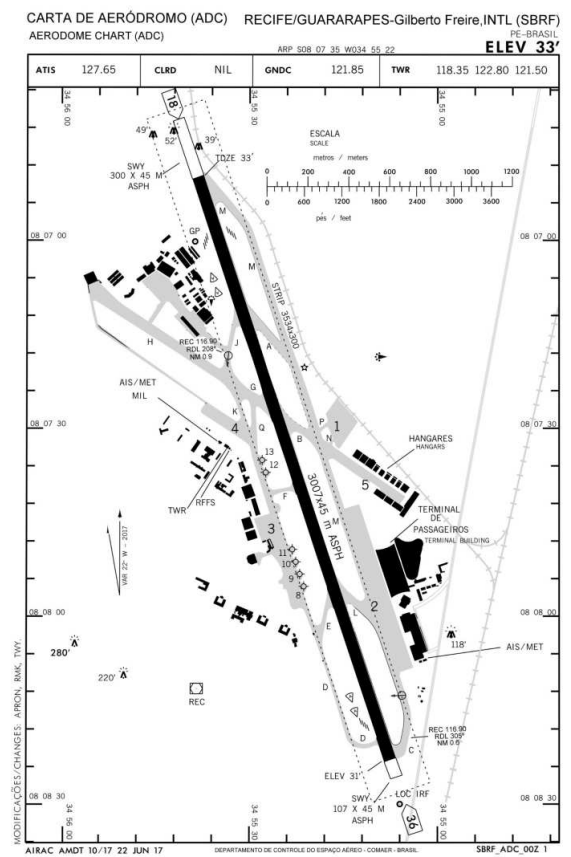

Fonte: DECEA (fev/2019)

Designativo ICAO: SBRF; Capacidade de atendimento: 16.500 .000 passageiros/ano; Demanda atendida em 2017: 7.483.577 passageiros; PPD: 1 pista, pavimento flexível, dimensões - 3.007 x 45 m; Pátio de estacionamento de aeronaves: $110.000 \mathrm{~m}^{2}$, pavimento rígido.

\section{Aeroporto Santos Dumont - Rio de Janeiro/RJ}

\section{Figura A-41 - Sítio aeroportuário - Aeroporto Santos Dumont}

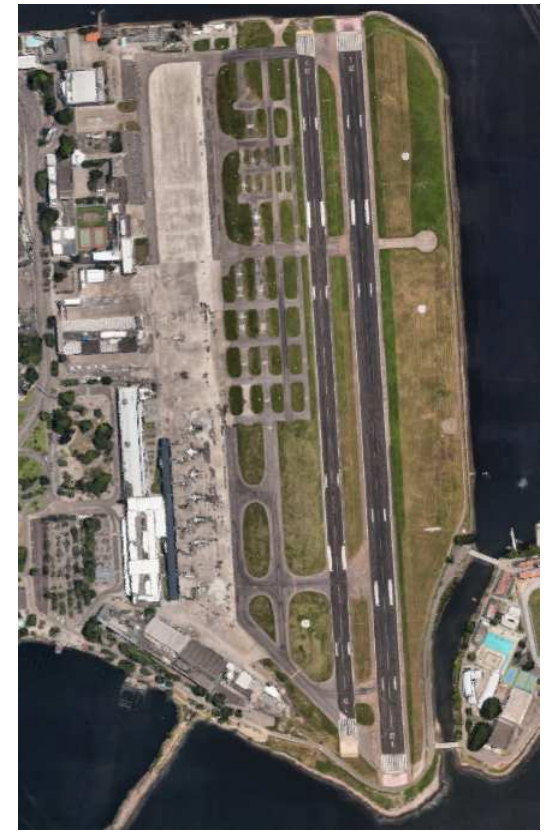

Fonte: GOOGLE MAPS (fev/2019)

\section{Figura A-42 - Carta aeronáutica do Aeroporto Santos Dumont}

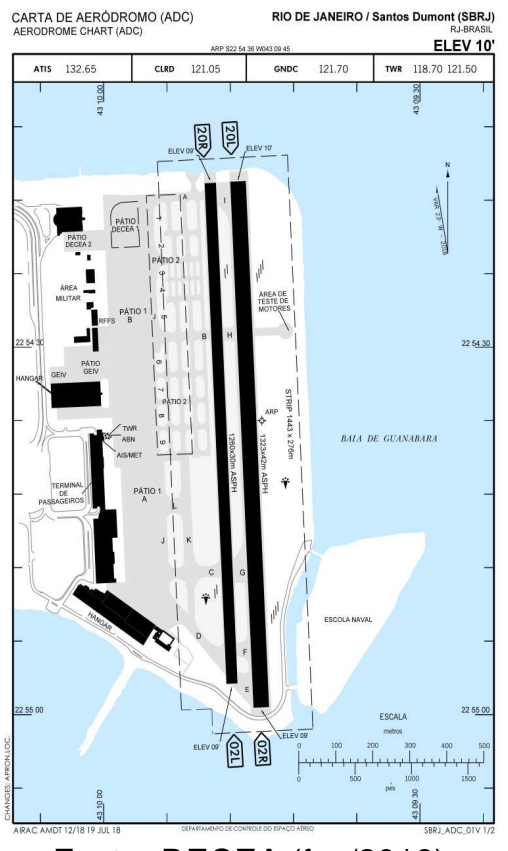

Fonte: DECEA (fev/2019)

Designativo ICAO: SBRJ; Capacidade de atendimento: 9.900 .000 passageiros/ano; Demanda atendida em 2017: 9.070.574 passageiros; PPD: 2 pistas, pavimento flexível, dimensões da pista principal - 1.323 x $42 \mathrm{~m}$; Pátio de estacionamento de aeronaves: $60.000 \mathrm{~m}^{2}$, pavimento rígido. 


\section{Aeroporto Internacional Marechal Cunha Machado - São Luís/MA}

Figura A-43 - Sítio aeroportuário - Aeroporto Internacional Marechal Cunha Machado

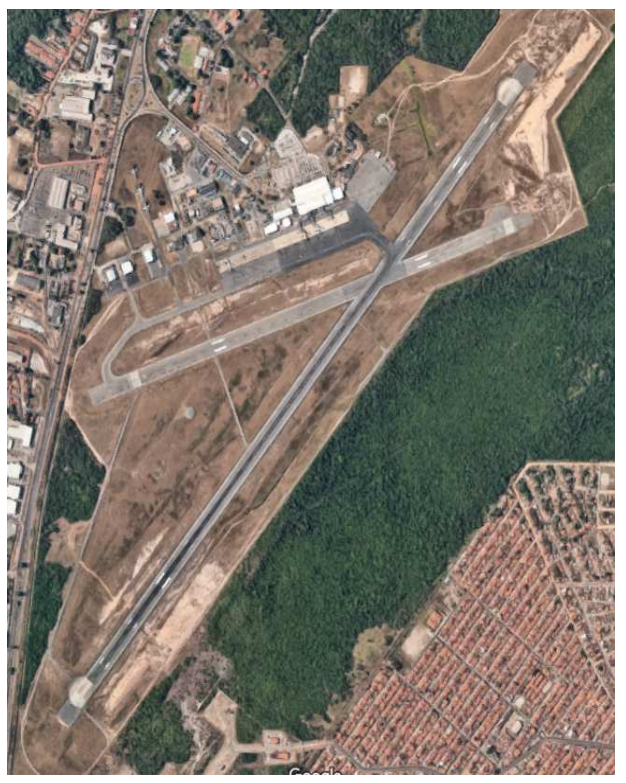

Fonte: GOOGLE MAPS (fev/2019)
Figura A-44 - Carta aeronáutica do Aeroporto Internacional Mal. Cunha Machado

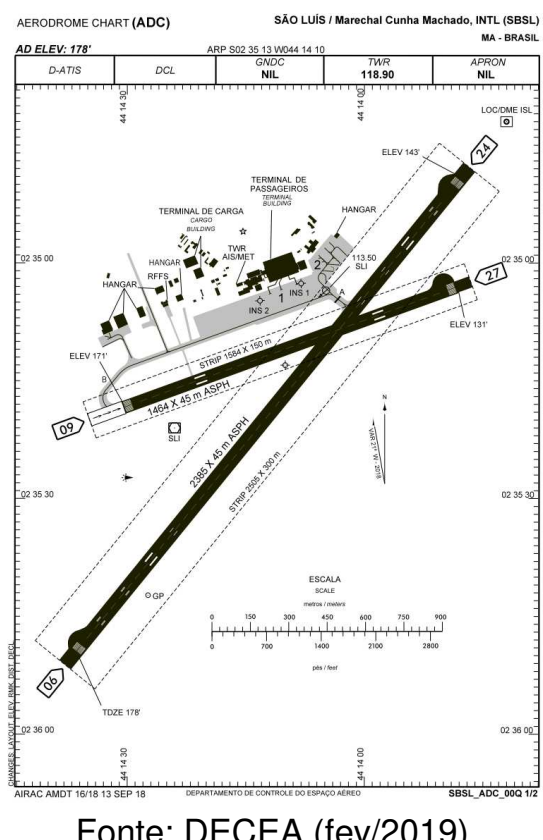

Fonte: DECEA (fev/2019)

Designativo ICAO: SBSL; Capacidade de atendimento: 5.100 .000 passageiros/ano; Demanda atendida em 2017: 1.536.692 passageiros; PPD: 2 pistas, pavimento flexível, dimensões da principal - $2.385 \mathrm{x}$ $45 \mathrm{~m}$; Pátio de estacionamento de aeronaves: $35.000 \mathrm{~m}^{2}$, pavimento rígido.

\section{Aeroporto Internacional Maestro Wilson Fonseca - Santarém/PA}

Figura A-45 - Sítio aeroportuário - Aeroporto Internacional Maestro Wilson Fonseca

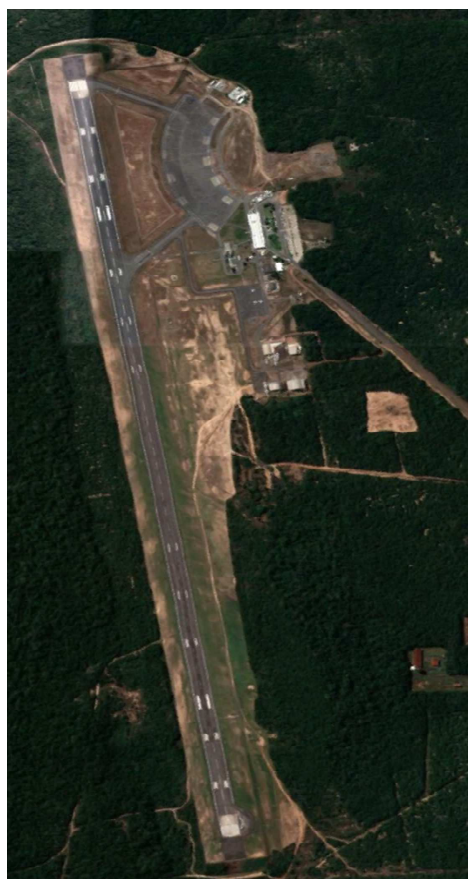

Fonte: GOOGLE MAPS (fev/2019)
Figura A-46 - Carta aeronáutica do Aeroporto Int. Mtro. Wilson Fonseca

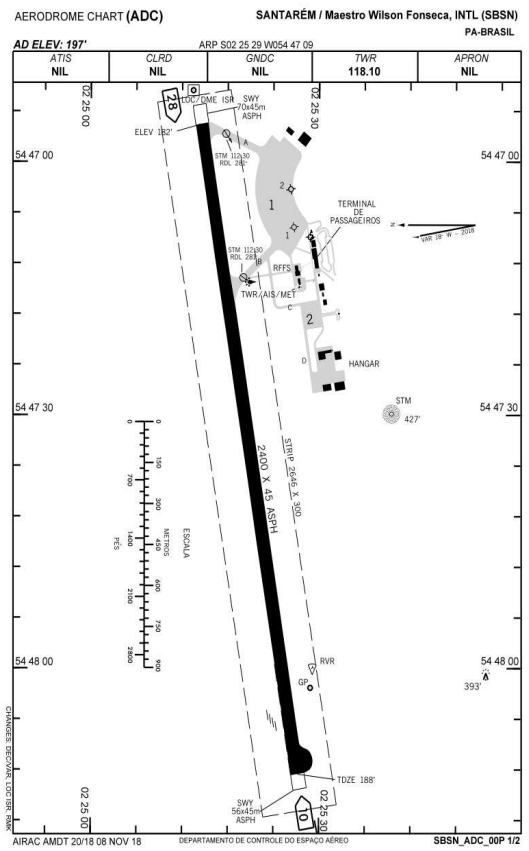

Fonte: DECEA (fev/2019)

Designativo ICAO: SBSN; Capacidade de atendimento: 1.830 .000 passageiros/ano; Demanda atendida em 2017: 442.754 passageiros; PPD: 1 pista, pavimento flexível, dimensões - 2.400 x 45 m; Pátio de estacionamento de aeronaves: $30.000 \mathrm{~m}^{2}$, pavimento rígido. 


\section{Aeroporto Congonhas / Deputado Freitas Nobre - São Paulo/SP}

\section{Figura A-47 - Sítio aeroportuário - Aeroporto Congonhas}

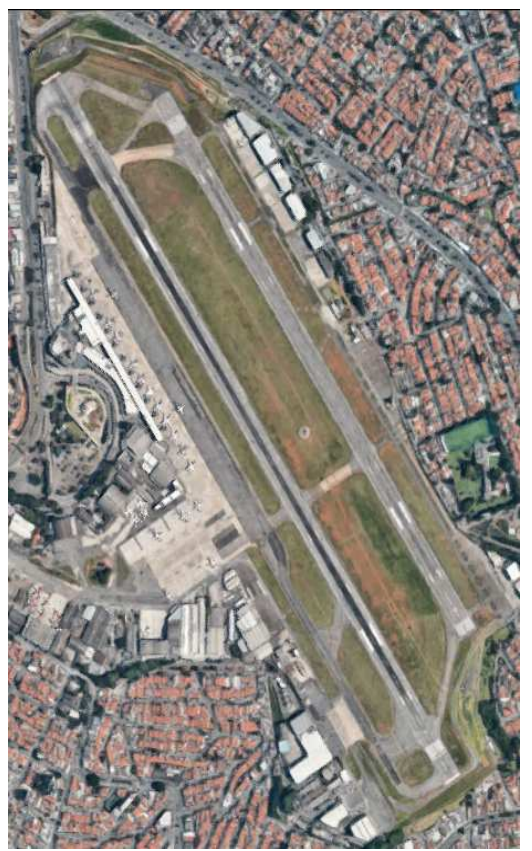

Fonte: GOOGLE MAPS (fev/2019)
Figura A-48 - Carta aeronáutica do Aeroporto Congonhas

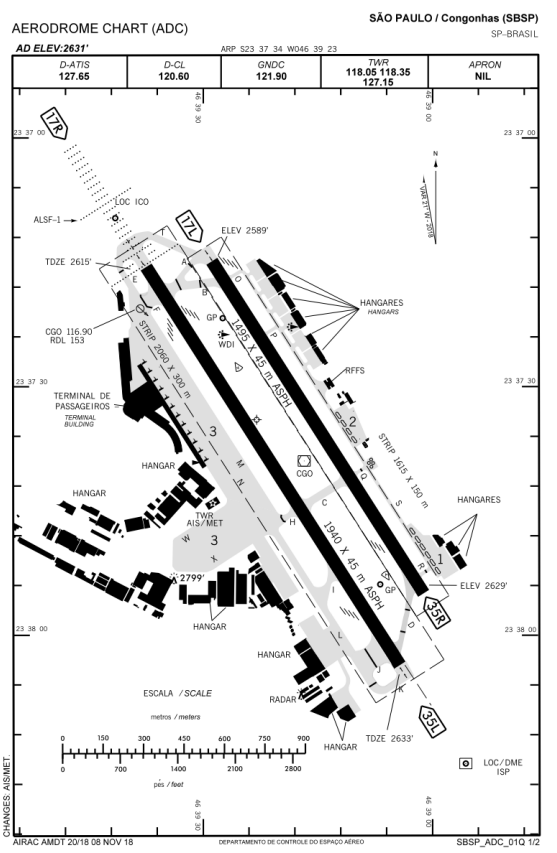

Fonte: DECEA (fev/2019)

Designativo ICAO: SBSP; Capacidade de atendimento: 17.100 .000 passageiros/ano; Demanda atendida em 2017: 21.505.285 passageiros; PPD: 2 pistas, pavimento flexível, dimensões da principal - 1.940 x 45 m; Pátio de estacionamento de aeronaves: $75.000 \mathrm{~m}^{2}$, pavimento rígido.

\section{Aeroporto Senador Petrônio Portella - Teresina/PI}

Figura A-49 - Sítio aeroportuário - Aeroporto Senador Petrônio Portella

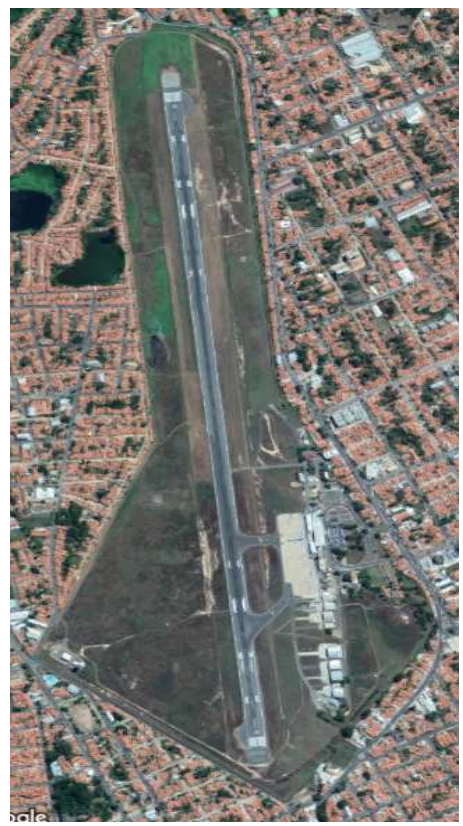

Fonte: GOOGLE MAPS (fev/2019)
Figura A-50 - Carta aeronáutica do Aeroporto Senador Petrônio Portella

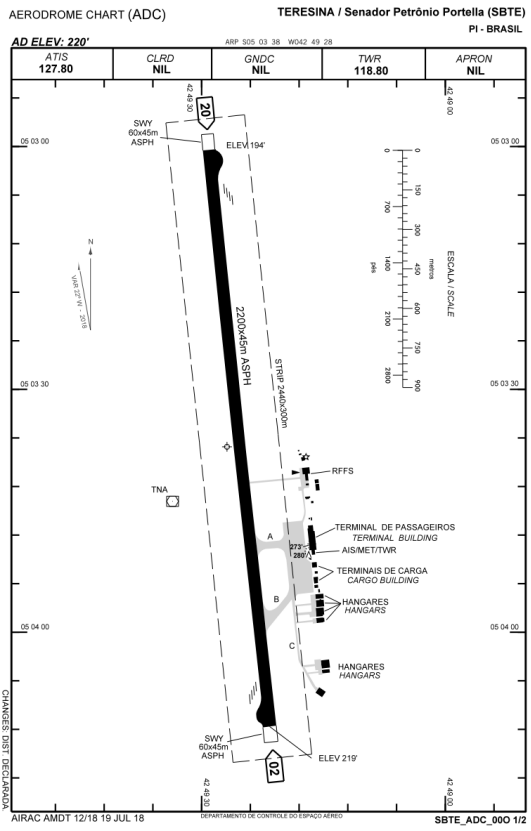

Fonte: DECEA (fev/2019)

Designativo ICAO: SBTE; Capacidade de atendimento: 1.700 .000 passageiros/ano; Demanda atendida em 2017: 1.059.081 passageiros; PPD: 1 pista, pavimento flexível, dimensões - 2.200 x 45 m; Pátio de estacionamento de aeronaves: $15.000 \mathrm{~m}^{2}$, pavimento rígido. 
26. Aeroporto Tenente Coronel Aviador César Bombonato - Uberlândia/MG

Figura A-51 - Sítio aeroportuário - Aeroporto Tenente Coronel Aviador César Bombonato

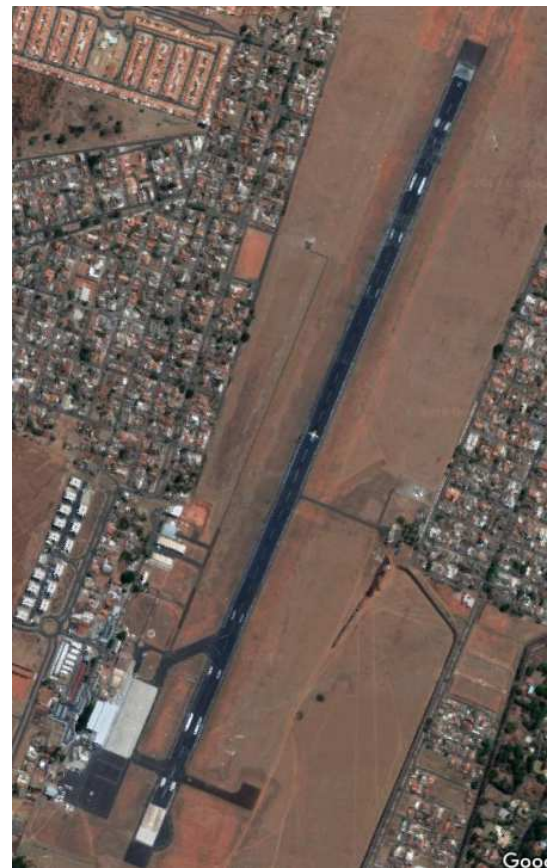

Fonte: GOOGLE MAPS (fev/2019)
Figura A-52 - Carta aeronáutica do Aeroporto Ten. Cel. Av. César Bombonato

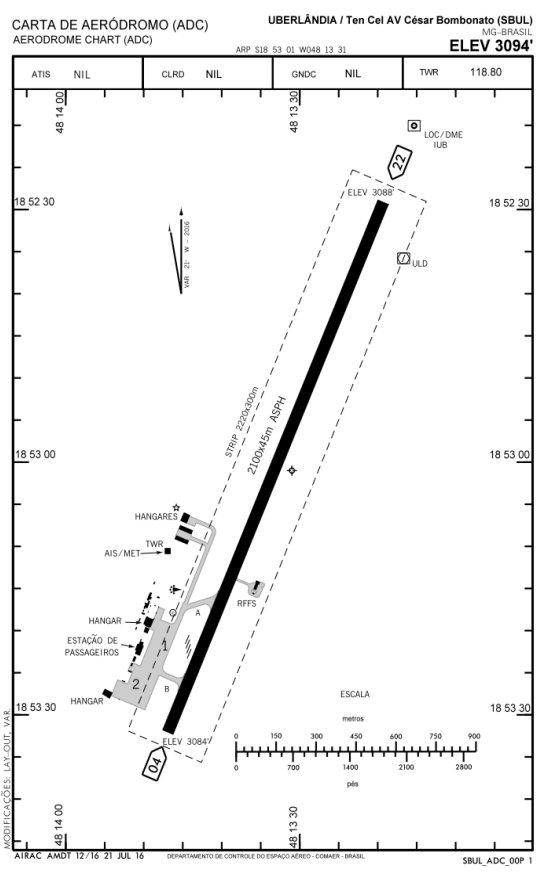

Fonte: DECEA (fev/2019)

Designativo ICAO: SBUL; Capacidade de atendimento: 2.400 .000 passageiros/ano; Demanda atendida em 2017: 1.029.103 passageiros; PPD: 1 pista, pavimento flexível, dimensões - 2.100 x 45 m; Pátio de estacionamento de aeronaves: $15.000 \mathrm{~m}^{2}$, pavimento rígido.

\section{Aeroporto Eurico de Aguiar Salles - Vitória/ES}

Figura A-53 - Sítio aeroportuário - Aeroporto Eurico de Aguiar Salles

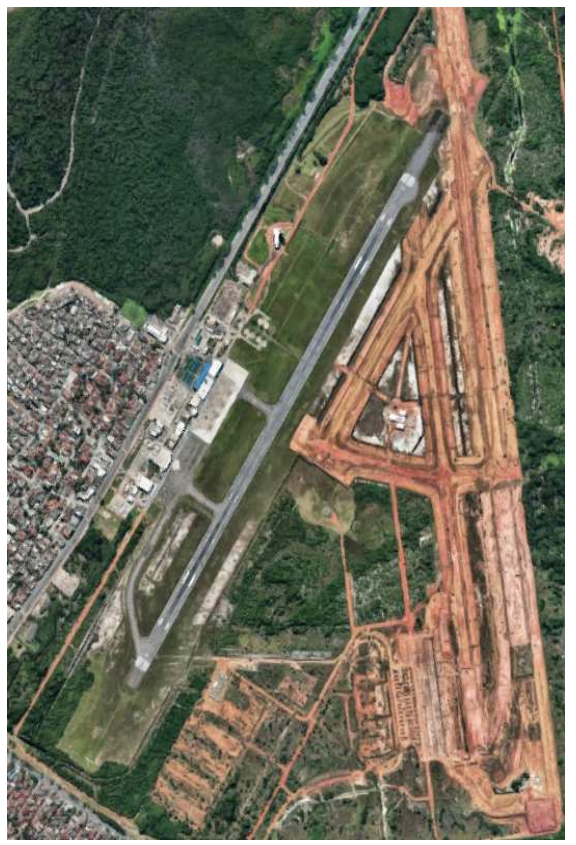

Fonte: GOOGLE MAPS (fev/2019)
Figura A-54 - Carta aeronáutica do Aeroporto Eurico de Aguiar Salles

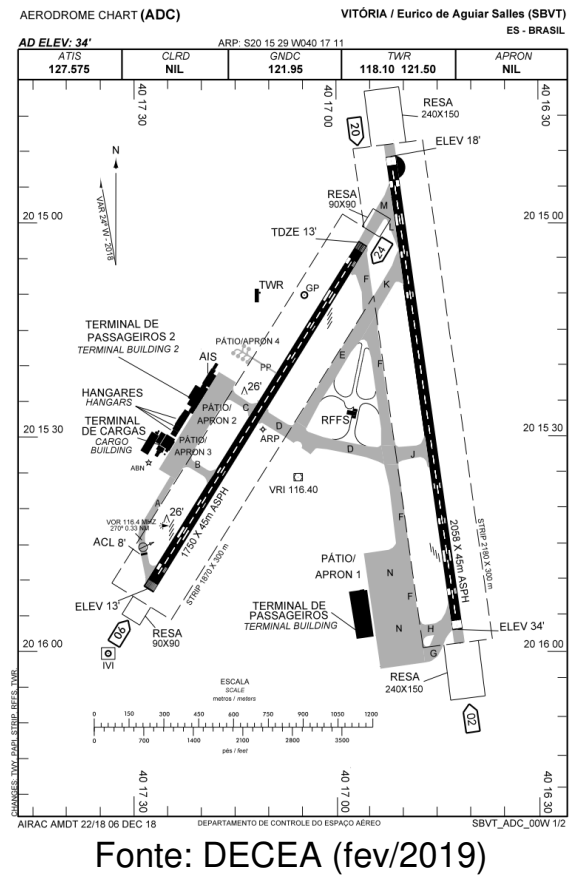

Designativo ICAO: SBVT; Capacidade de atendimento: 8.400 .000 passageiros/ano; Demanda atendida em 2017: 2.892.841 passageiros; PPD: 2 pistas, pavimento flexível, principal com dimensões - $2.058 \mathrm{x}$ $45 \mathrm{~m}$; Pátio de estacionamento de aeronaves: $30.000 \mathrm{~m}^{2}$, pavimento rígido. 


\section{APÊNDICE B}

Tabela B-1 - Estrutura de pavimento flexível

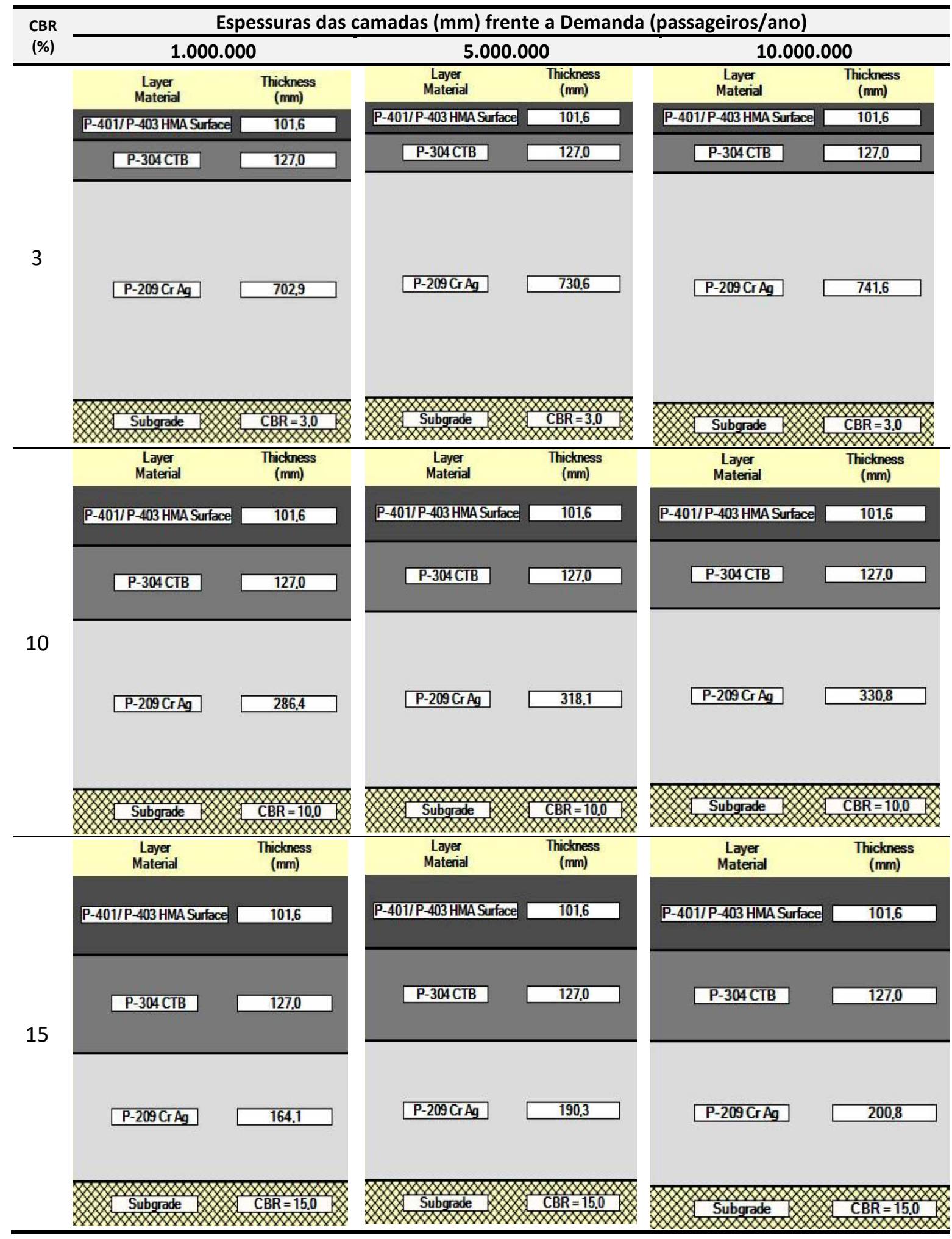

Fonte: Software FAARFIELD v 1.42 
Tabela B-2 - Estrutura de pavimento rígido

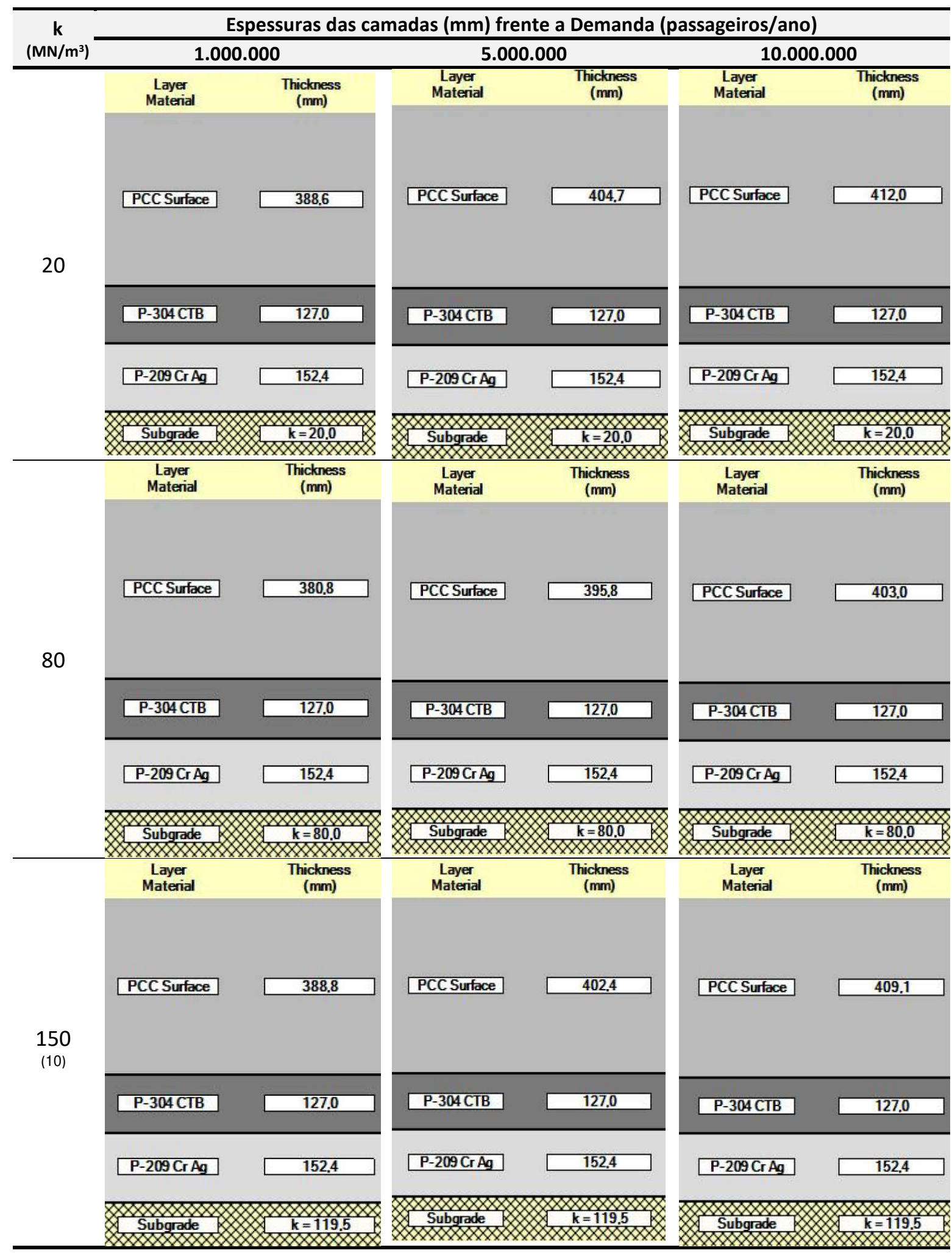

Fonte: Software FAARFIELD v 1.42

10 O software empregado limita o valor de $\mathrm{k}$ a $119,5 \mathrm{MN} / \mathrm{m}^{3}$, seguindo o tutorial, considera-se tal valor para $\mathrm{k} \geq 119,5 \mathrm{MN} / \mathrm{m}^{3}$. 
Tabela B-3 - Espessuras das camadas para cada modelamento de pavimento

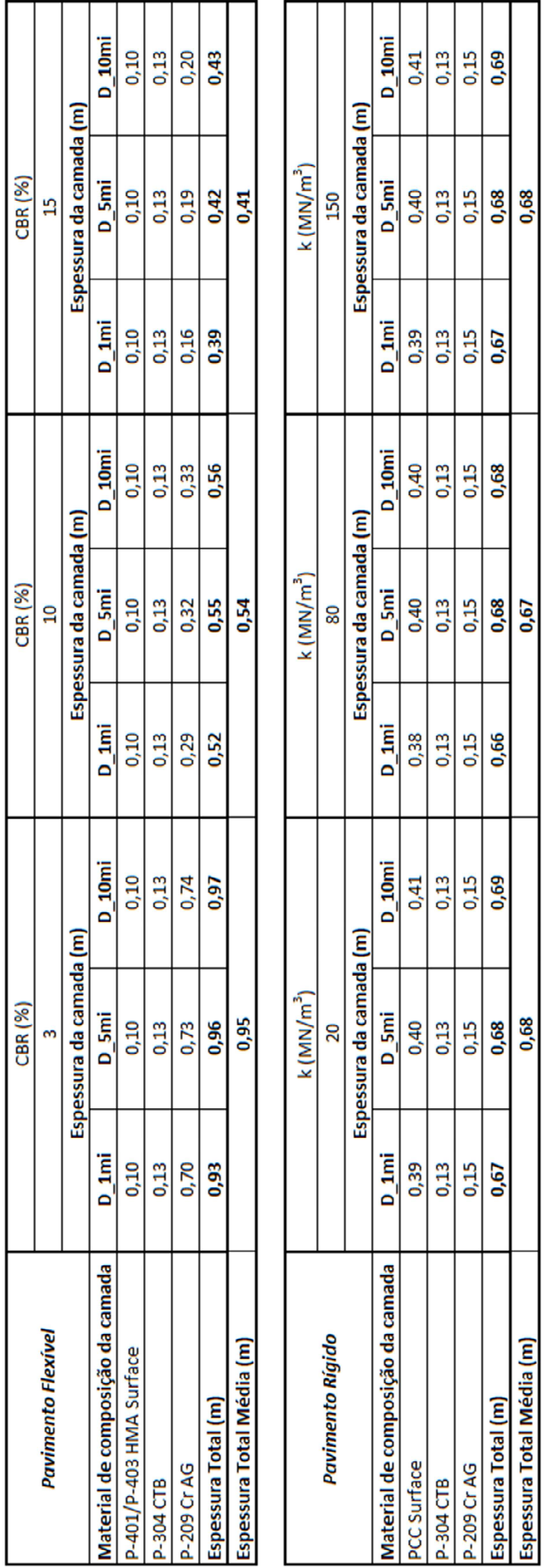

Fonte: Elaboração Própria, com base no Software FAARFIELD v 1.42 


\section{APÊNDICE C}

Tabela C-1 - Quantitativos para execução de uma unidade $\left(\mathrm{m}^{2}\right)$ de pavimento

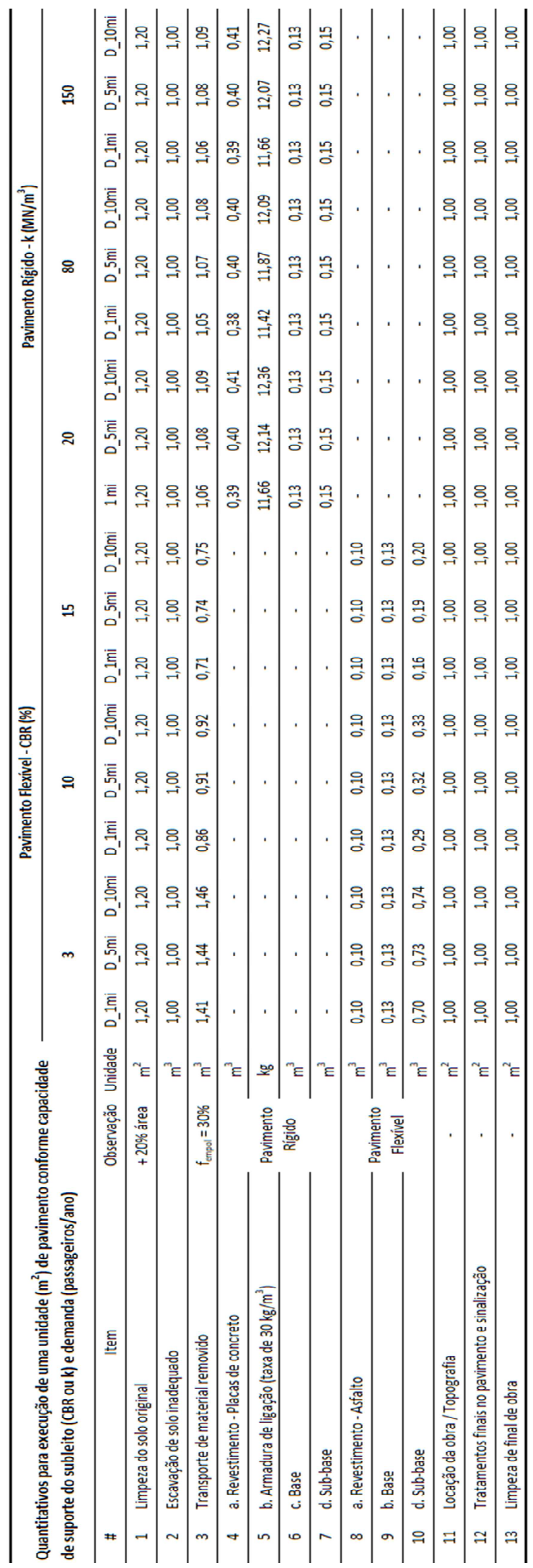

Fonte: Elaboração Própria, com base no Software FAARFIELD v 1.42 
Tabela C-2 - Estimativa de Custos para execução de uma unidade $\left(\mathrm{m}^{2}\right)$ de pavimento

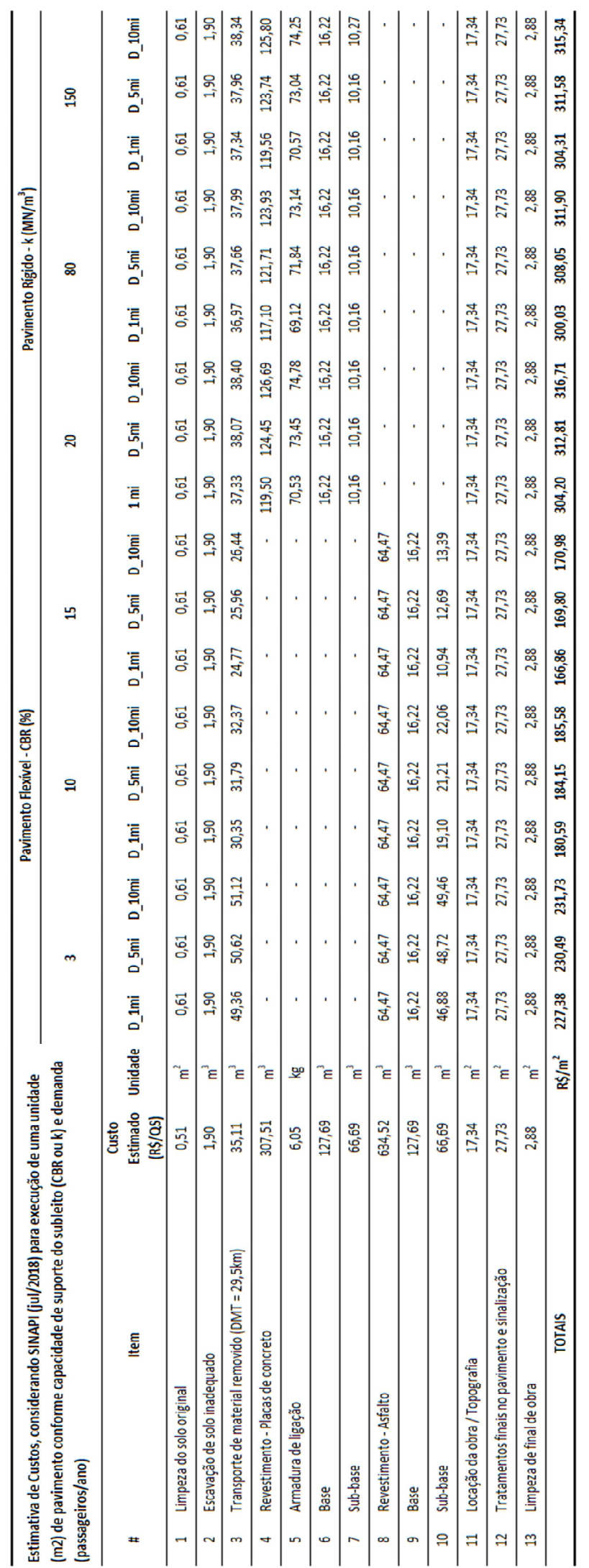

Fonte: Elaboração Própria, com base em SINAPI (jul/2018) 
ANEXO A

Quadro A-1 - Descrição dos itens considerados para estimativa dos custos no estudo

\begin{tabular}{|c|c|c|c|c|c|}
\hline \# & Item & Grupo de Serviço & Atividade & $\begin{array}{l}\text { Código } \\
\text { SINAPI }\end{array}$ & Descrição do Serviço \\
\hline 1 & $\begin{array}{l}\text { Limpeza do } \\
\text { solo original }\end{array}$ & $\begin{array}{l}\text { SERVIÇOS } \\
\text { PRELIMINARES }\end{array}$ & $\begin{array}{l}\text { PREPARO DO } \\
\text { TERRENO }\end{array}$ & $73822 / 2$ & $\begin{array}{l}\text { LIMPEZA MECANIZADA DE } \\
\text { TERRENO COM REMOÇÃO } \\
\text { DE CAMADA VEGETAL, } \\
\text { UTILIZANDO } \\
\text { MOTONIVELADORA }\end{array}$ \\
\hline 2 & $\begin{array}{l}\text { Escavação de } \\
\text { solo } \\
\text { inadequado } \\
\text { para execução } \\
\text { do pavimento }\end{array}$ & $\begin{array}{l}\text { MOVIMENTO DE } \\
\text { TERRA }\end{array}$ & $\begin{array}{l}\text { CORTE / } \\
\text { ESCAVAÇÃO EM } \\
\text { JAZIDAS OU } \\
\text { CAMPO ABERTO }\end{array}$ & $73903 / 2$ & $\begin{array}{l}\text { EXPURGO DE JAZIDA } \\
\text { (MATERIAL VEGETAL, OU } \\
\text { INSERVÍVEL) }\end{array}$ \\
\hline 3 & $\begin{array}{l}\text { Transporte de } \\
\text { material } \\
\text { removido }\end{array}$ & $\begin{array}{l}\text { TRANPORTES, } \\
\text { CARGAS E } \\
\text { DESCARGAS }\end{array}$ & $\begin{array}{l}\text { TRANSPORTE } \\
\text { COMERCIAL }\end{array}$ & 95425 & $\begin{array}{l}\text { TRANSPORTE COM } \\
\text { CAMINHÃO BASCULANTE DE } \\
18 \mathrm{M}^{3} \text {, EM VIA URBANA EM } \\
\text { LEITO NATURAL }\end{array}$ \\
\hline 4 & $\begin{array}{l}\text { Revestimento } \\
\text { - Placas de } \\
\text { concreto }\end{array}$ & $\begin{array}{l}\text { FUNDAÇÕES E } \\
\text { ESTRUTURAS }\end{array}$ & $\begin{array}{l}\text { LASTROS / } \\
\text { FUNDACOES } \\
\text { DIVERSAS }\end{array}$ & 97096 & $\begin{array}{l}\text { CONCRETAGEM DE RADIER, } \\
\text { PISO OU LAJE SOBRE SOLO, } \\
\text { FCK } 30 \text { MPA - LANÇAMENTO, } \\
\text { ADENSAMENTO E } \\
\text { ACABAMENTO }\end{array}$ \\
\hline 5 & $\begin{array}{l}\text { Armadura de } \\
\text { ligação }\end{array}$ & PAVIMENTAÇÃO & $\begin{array}{l}\text { EXECUÇÃO DE } \\
\text { PAVIMENTACOES } \\
\text { DIVERSAS }\end{array}$ & 97120 & $\begin{array}{l}\text { BARRAS DE LIGAÇÃO, AÇO } \\
\text { CA-50 DE } 10 \text { MM, PARA } \\
\text { EXECUÇÃO DE PAVIMENTO } \\
\text { DE CONCRETO - } \\
\text { FORNECIMENTO E } \\
\text { INSTALAÇÃO }\end{array}$ \\
\hline 6 & Base & PAVIMENTAÇÃO & $\begin{array}{l}\text { EXECUÇÃO DE } \\
\text { SUB-LEITO, LEITO, } \\
\text { SUB-BASE, BASE } \\
\text { ETC }\end{array}$ & 96398 & $\begin{array}{l}\text { EXECUÇẪO E } \\
\text { COMPACTAÇÃO DE BASE E } \\
\text { OU SUB-BASE COM } \\
\text { CONCRETO COMPACTADO } \\
\text { COM ROLO - EXCLUSIVE } \\
\text { CARGA E TRANSPORTE }\end{array}$ \\
\hline 7 & Sub-base & PAVIMENTAÇÃO & $\begin{array}{l}\text { EXECUÇÃO DE } \\
\text { SUB-LEITO, LEITO, } \\
\text { SUB-BASE, BASE, } \\
\text { ETC }\end{array}$ & 96399 & $\begin{array}{l}\text { EXECUÇÃO E } \\
\text { COMPACTAÇÃO DE BASE E } \\
\text { OU SUB BASE COM PEDRA } \\
\text { RACHÃO - EXCLUSIVE } \\
\text { ESCAVAÇÃO, CARGA E } \\
\text { TRANSPORTE }\end{array}$ \\
\hline 8 & $\begin{array}{l}\text { Revestimento } \\
\text { - Asfalto }\end{array}$ & PAVIMENTAÇÃO & $\begin{array}{l}\text { EXECUÇÃO DE } \\
\text { PAVIMENTAÇÕES } \\
\text { DIVERSAS }\end{array}$ & $73849 / 1$ & $\begin{array}{l}\text { ASFALTO A QUENTE (AAUQ) } \\
\text { COM CAP 50/70, INCLUSO } \\
\text { USINAGEM E APLICACAO }\end{array}$ \\
\hline 9 & Base & PAVIMENTAÇÃO & $\begin{array}{l}\text { EXECUÇÃO DE } \\
\text { SUB-LEITO, LEITO, } \\
\text { SUB-BASE, BASE, } \\
\text { ETC }\end{array}$ & 96398 & $\begin{array}{l}\text { EXECUÇÃO E } \\
\text { COMPACTAÇÃO DE BASE E } \\
\text { OU SUB BASE COM } \\
\text { CONCRETO COMPACTADO } \\
\text { COM ROLO - EXCLUSIVE } \\
\text { CARGA E TRANSPORTE } \\
\end{array}$ \\
\hline 10 & Sub-base & PAVIMENTAÇÃO & $\begin{array}{l}\text { EXECUÇÃO DE } \\
\text { SUB-LEITO, LEITO, } \\
\text { SUB-BASE, BASE, } \\
\text { ETC }\end{array}$ & 96399 & $\begin{array}{l}\text { EXECUÇÃO E } \\
\text { COMPACTAÇÃO DE BASE E } \\
\text { OU SUB BASE COM PEDRA } \\
\text { RACHÃO - EXCLUSIVE } \\
\text { ESCAVAÇÃO, CARGA E } \\
\text { TRANSPORTE }\end{array}$ \\
\hline 11 & $\begin{array}{l}\text { Locação da } \\
\text { obra / } \\
\text { Topografia }\end{array}$ & $\begin{array}{l}\text { SERVIÇOS } \\
\text { TÉCNICOS }\end{array}$ & LOCAÇÃO & 73686 & $\begin{array}{l}\text { LOCAÇÃO DA OBRA, COM } \\
\text { USO DE EQUIPAMENTOS } \\
\text { TOPOGRÁFICOS, INCLUSIVE } \\
\text { NIVELADOR }\end{array}$ \\
\hline 12 & $\begin{array}{l}\text { Tratamentos } \\
\text { finais no } \\
\text { pavimento e } \\
\text { sinalização }\end{array}$ & PAVIMENTAÇÃO & $\begin{array}{l}\text { SINALIZAÇÃO } \\
\text { HORIZONTAL / } \\
\text { VERTICAL }\end{array}$ & 72947 & $\begin{array}{l}\text { SINALIZAÇÃO HORIZONTAL } \\
\text { COM TINTA } \\
\text { RETRORREFLETIVA A BASE } \\
\text { DE RESINA ACRILICA COM } \\
\text { MICROESFERAS DE VIDRO }\end{array}$ \\
\hline 13 & $\begin{array}{l}\text { Limpeza de } \\
\text { final de obra }\end{array}$ & $\begin{array}{l}\text { SERVICOS } \\
\text { DIVERSOS }\end{array}$ & $\begin{array}{l}\text { LIMPEZA E } \\
\text { ARREMATES } \\
\text { FINAIS } \\
\end{array}$ & 9537 & LIMPEZA FINAL DA OBRA \\
\hline
\end{tabular}

Fonte: SINAPI (jul/2018) 